\title{
Technical modifications of DNA flow cytometry and their applications in surgical pathology
}

Citation for published version (APA):

Leers, M. P. G. (1999). Technical modifications of DNA flow cytometry and their applications in surgical pathology. [Doctoral Thesis, Maastricht University]. Universiteit Maastricht. https://doi.org/10.26481/dis.19991217ml

Document status and date:

Published: 01/01/1999

DOI:

10.26481/dis. $19991217 \mathrm{ml}$

Document Version:

Publisher's PDF, also known as Version of record

\section{Please check the document version of this publication:}

- A submitted manuscript is the version of the article upon submission and before peer-review. There can be important differences between the submitted version and the official published version of record.

People interested in the research are advised to contact the author for the final version of the publication, or visit the DOI to the publisher's website.

- The final author version and the galley proof are versions of the publication after peer review.

- The final published version features the final layout of the paper including the volume, issue and page numbers.

Link to publication

\footnotetext{
General rights rights.

- You may freely distribute the URL identifying the publication in the public portal. please follow below link for the End User Agreement:

www.umlib.nl/taverne-license

Take down policy

If you believe that this document breaches copyright please contact us at:

repository@maastrichtuniversity.nl

providing details and we will investigate your claim.
}

Copyright and moral rights for the publications made accessible in the public portal are retained by the authors and/or other copyright owners and it is a condition of accessing publications that users recognise and abide by the legal requirements associated with these

- Users may download and print one copy of any publication from the public portal for the purpose of private study or research.

- You may not further distribute the material or use it for any profit-making activity or commercial gain

If the publication is distributed under the terms of Article $25 \mathrm{fa}$ of the Dutch Copyright Act, indicated by the "Taverne" license above, 
Het drukken van dit proefschrift werd financieel mede ondersteund door:

Dr.Ir. van der Laar Stichting

Eli Lily 
TECHNICAL MODIFICATIONS OF DNA FLOW CYTOMETRY AND THEIR APPLICATIONS IN SURGICAL PATHOLOGY 
(C) MPG Leers, Sittard 1999

All rights reserved. No part of this book may be reproduced, stored in a retrieval system, or transmitted, in any form or by any means, electronic, mechanical, photocopying, recording, or otherwise, without the prior written permission of the holder of the copyright. 


\title{
TECHNICAL MODIFICATIONS OF DNA FLOW CYTOMETRY AND THEIR APPLICATIONS IN SURGICAL PATHOLOGY
}

\author{
PROEFSCHRIFT \\ ter verkrijging van de graad van doctor \\ aan de Universiteit Maastricht, \\ op gezag van de Rector Magnificus, \\ Prof.dr. A.C. Nieuwenhuijzen Kruseman \\ volgens het besluit van het College van Decanen, \\ in het openbaar te verdedigen \\ op vrijdag 17 december 1999 om 12.00 uur
}

door

MATHEUS PETER GERTRUDA LEERS

Geboren op 13 juni 1966

te Sittard 


\section{Promotor:}

Prof.dr. F.C.S. Ramaekers

Co-promotores:

Dr. M. Nap

Dr. B. Schutte

Beoordelingscommissie:

Prof.dr. J.W. Arends (voorzitter)

Dr. A. Begg (NKI, Amsterdam)

Prof.dr. C. Cornelisse (Universiteit Leiden)

Prof.dr. M.F. von Meyenfeldt

Prof.dr. J. Wagstaff

Publication of this thesis was partially financed by DAKO A/S, Denmark

Integraal Kankercentrum Limburg ITK diagnostics BV

Klinipath BV

SANBIO BV 
Numbers constitute the only universal language

Nathanial West 1903-1940

Voor Bianca, Sanne en Veerle 

Chapter 1

Section I

Chapter 2

Chapter 3

Chapter 4

Chapter 5

Section II

Chapter 6

Chapter 7

Chapter 8

Chapter 9

Chapter 10
General introduction:

Multiparameter flow cytometry: applications in the assessment of tissue homeostasis and tumorbiodynamics

\section{Technical developments}

embedded samples from colorectal carcinomas

$\mathrm{Ag}$ in paraffin embedded mammary carcinomas

paraffin embedded tumor tissue

neo-epitope exposed during early apoptosis

Trivariate flow cytometric analysis of paraffin-embedded lung cancer specimens: application of cytokeratin subtype specific antibodies to distinguish between differentiation pathways

A novel flow cytometric steroid hormone receptor assay for paraffin embedded breast carcinomas: an objective quantification of the steroid hormone receptors and direct correlation to ploidy status and proliferative capacity in a single-tube assay

Clonality assessment of lymphoproliferative disorders by multiparameter flow cytometry using paraffin embedded tissue: an additional diagnostic tool in surgical pathology

Apoptosis, bcl-2 expression and proliferation in endometrial adenocarcinoma: an approach using multiparameter flow cytometry

Summary, general discussion and conclusion

Samenvatting

List of publications

Dankwoord

Curriculum Vitae 


\section{List of abbreviations}

AC

AEC

$\mathrm{Ag}$

BrdU

BSA

CD

CK

$\mathrm{CV}$

DAB

DNA

DI

ER

FCM

FIGO

FITC

Ig

$\mathrm{kDa}$

LCAC

LI

$\mathrm{MoAb}$

NSCLC

PBS

PCNA

PI

FFPE

PR

RFI

RPE

RT

SCLC

SD

SDS

SPF

SQC

SSC

UG

WHO
Adenocarcinoma

Aminoethylcarbazole

Antigen

5-bromo-2'-deoxyuridine

Bovine serum albumin

Cluster differentiation

Cytokeratin

Coefficient of variation

Diaminobenzidine tetrahydrochloride

Deoxyribonucleic acid

DNA index

Estrogen receptor

Flow cytometry

International Federation of Gynaecology and Obstetrics

Fluorescein isothiocyanate

Immunoglobulin

Kilodalton

Large cell anaplastic carcinoma

Labeling index

Monoclonal antibody

Non-small cell lung carcinoma

Phosphate buffered saline

Proliferating cell nuclear antigen

Propidium iodide

Formalin fixed, paraffin embedded

Progesterone receptor

Relative fluorescence intensity

$\mathrm{r}$-Phycoerytrein

Room temperature

Small cell lung carcinoma

Standard deviation

Sodium dodecylsulphate

S-phase fraction

Squamous cell carcinoma

Standard saline citrate

Ungated

World Health Organization 


\section{General introduction}

Multiparameter flow cytometry: applications in the assessment of tissue homeostasis and tumorbiodynamics 


\section{Introduction}

\subsection{Problems in the daily practice of surgical pathology}

In surgical pathology microscopy of cytological or histological preparations is the most essential part of daily practice in order to discriminate between benign, premalignant and malignant cell proliferations. Despite the fact that in the majority of cases the diagnosis can be reliably established in this way, a continuous search for additional parameters, such as 'predictors' for response to therapy or prognosis of the disease, are necessary. Improvement of the diagnosis can be obtained by the use of immunohistochemistry as additional tool by the surgical pathologist, but this is not always satisfactory. For example, clonality assessment in B-cell lymphomas is still difficult to perform with immunohistochemistry due to lack of staining contrast between surface-immunoglobulins and extracellular immunoglobulins 99 .

The implementation of molecular biological techniques in pathology allows new concepts to be used in the establishment of the diagnosis and the prediction of tumor behaviour. Yet, quantification of cell biological parameters can be of importance to improve diagnosis and predict therapy response like in the assessment of steroid hormone receptors for patients with breast cancer. However, the subjectivity of interpretation and quantification still is an unsolved problem. The biological aspects that can be examined in this way include cell proliferation, differentiation and cell death. These three different items are the corner stones of tissue homeostasis and constitute important factors in controlling expansion or regression in tumors ${ }^{39}$. Tumorigenesis can be viewed as a process of cellular evolution in which individual cells acquire mutations that increase proliferative capacity or decrease the apoptotic activity. The control of proliferation depends on interlinked hierarchical systems of intracellular communication. The multiple elements that comprise the regulatory pathways collectively allow fine control of cell proliferation and provide a system of check points that prevent disordered growth. Many components are now recognised as regulators of cell and tissue growth, i.e. growth factors and their receptors (e.g. steroid hormones and steroid hormone receptors), membrane-associated and cytoplasmic signal transduction molecules and tumor suppressor gene products (e.g. p53 and the retinoblastoma gene). These mechanisms also include repairing of damaged DNA and induction of cell cycle arrest or apoptosis when individual stages in the cell cycle are not appropriately completed. The growth potential and behaviour of human neoplasms is the net result of an imbalance between cell proliferation and cell death. Several investigators showed a correlation between the proliferation rates of certain tumors and their biological behavior ${ }^{3,4,72}$. It is only during the past few years that serious mechanistic studies are launched on the relation between apoptosis and the biological behavior in tumors. Methods that allow the specific quantification of such cell biological parameters may contribute to our understanding of the mutual relationship between these factors in tumor growth, and aid in the managment of malignancies. 


\subsection{Cell Proliferation}

\subsubsection{THE CELL CYCLE}

Development, growth, renewal and maintenance of organisms are dependent on the formation of new cells out of parent cells. In other words, the cells need to be copied. This takes place through a process known as the cell cycle. The normal cell cycle is divided into four phases (see also fig. 1):

1. $\mathrm{G}_{1}$-phase: the cells have a diploid or $2 \mathrm{~N}$ DNA content (equivalent to 46 chromosomes in humans)

2. S-phase: the cycling cells replicate their DNA and have an amount of DNA varying between $2 \mathrm{~N}$ and $4 \mathrm{~N}$. The fraction of cells in the S-phase (SPF) is often used as indication of proliferative status of a tissue

3. $\mathrm{G}_{2}$-phase: the cells have a double $(4 \mathrm{~N})$ or tetraploid DNA content.

4. M-phase: mitosis, the cell divides, thus forming the two daughter cells.

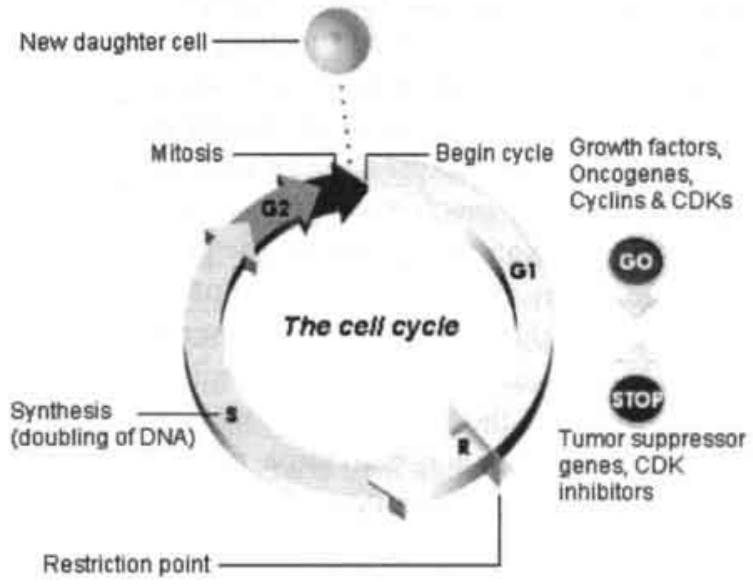

Figure 1. The cell cycle phases

The only stage recognizable to the microscopist is the mitotic phase. Cells produced at mitosis re-enter the $\mathrm{G}_{1}$-phase, which is the most variable in duration, and there are a number of biochemical events which occur during this phase that regulate exit from this phase. A separate $\mathrm{G}_{0}$-phase was proposed by Lajtha to account for cells that do not divide unless stimulated to do $s^{58}$. It is currently not possible to separate a very long $G_{1}$ from $G_{0}$. At a certain point after entering the $G_{1}$ phase the cells begin to duplicate their DNA. This phase, during which DNA is synthesized is termed the S-phase. This phase has duration in the order of 6-16 hr. When the cells have completely doubled their DNA content, they enter a second phase $-\mathrm{G}_{2}$. This phase typically lasts $4-8 \mathrm{hr}$. After this phase the cells enter mitosis.

In most tissues, there are proliferating and non-proliferating cells, the latter are either endstage, differentiated or resting. The cells, which are in the cell cycle, make up the growth fraction. The proliferation fraction and the cell cycle time determine the growth activity of any tissue. 


\subsubsection{CELL CYCLE REGULATION}

Molecular events in cell proliferation are complex and involve an increasing number of intercellular pathways and molecules. In normal physiological situations cell growth is controlled by the expression of cyclins. The cyclins comprise a family of protein subunits that form complexes with cyclin-dependent kinases (CDKs). These complexes function as holoenzymes that phosphorylate different sets of proteins at consecutive stages of the cell cycle, thereby driving the cell through the cycle ${ }^{48,49}$. For example, cyclin $\mathrm{D}_{1}$, which is located on chromosome 11 q13 (the gene is also known as bcl-1 and PRAD-1 ${ }^{108}$ ), is involved in the transition of cells through the $\mathrm{G}_{1}$-phase of the cell cycle ${ }^{76}$. Amplification or overexpression of cyclin $D_{1}$ may be responsible for increased tumor cell proliferation. In invasive breast carcinomas a correlation is found between amplification of cyclin D1 and poor prognosis ${ }^{90}$. On the other hand, a set of checkpoints monitor completion of the molecular events, and, if necessary, delay progression to the next phase of the cell cycle. In order for an organism to keep functioning, protecting the integrity of its genetic material is mandatory, because accumulation of damage to the DNA can lead to for example development of malignancies. To help prevent such damage, cells have evolved mechanisms and checkpoints to repair the damaged DNA. The p53 tumor suppressor gene product is one of the proteins, which serves as a "guardian of the genome". The p53 gene located on chromosome 17 encodes a nuclear protein, which binds to and modulates the expression of genes important for DNA repair, cell division and cell death by apoptosis. By mechanisms, which are still incompletely understood, damaged DNA stimulates the activation of ATM (a gene product mutated in ataxia telangiectasia). This product activates and phosphorylates p53, which is a downstream target of $\mathrm{ATM}^{8.18}$. This in turn enhances the synthesis of p21 and GADD45 ${ }^{61.95}$. The latter two proteins interact with PCNA, an essential co-factor for replicative DNA synthesis. The p21 protein also inhibits the activities of the cyclin-dependent kinase enzymes that push cells through the cell cycle ${ }^{115}$. In such a manner, activation of p53 by DNA damage causes cell growth arrest and DNA repair, until the restoration of DNA integrity permits proliferation to resume. Also p53 can upregulate the synthesis of Bax, a cell death gene. When DNA damage is irreparable, this pathway induces apoptosis. Because p53 is altered (mutated or rearranged) in a large number of human malignancies ${ }^{47}$, defects in the p53-dependent pathways may be a significant obstacle for successful cancer therapy. P53 status in cancer cells does affect the efficiacy of cancer treatment ${ }^{63}$.

\subsubsection{PROLIFERATION MARKERS}

The last decade much attention has been paid to gain insight into the proliferative compartment of a tumor. The use of immunohistochemical techniques enables the visualisation of specific cell cycle related antigens. There have been several developments in this area: a number of antibodies have become available which recognize proliferationassociated antigens such as Ki67 and PCNA.

$\mathrm{Ki}-67$ is one of the most widely used reagents for the immunohistochemical determination of cycling cells ${ }^{33}$. It is a monoclonal antibody reacting with a large nuclear non-histone protein doublet of 395 and $345 \mathrm{kDa}$ present in the cell cycle at late $\mathrm{G}_{1}, \mathrm{~S}, \mathrm{G}_{2}$ and mitosis, but absent in $\mathrm{G}_{0}$ and early $\mathrm{G}_{1}{ }^{34,35}$. Immunofluoresence staining gives a preferential staining of nucleoli and condensed chromosomes. Flow cytometric studies have shown that the amount of antigen varies throughout the cell cycle and reaches a maximum during $\mathrm{G}_{2}$ and mitosis-phase ${ }^{86,107}$. After mitosis the antigen is rapidly degraded (or the epitope lost), with the half-life of the 
detectable antigen being an hour or less ${ }^{17}$. A drawback of this monoclonal antibody was that it only recognized its epitope in fresh or frozen tissue. Recently, several antibodies have been developed which recognise the $\mathrm{Ki}-67$ specific epitope in formalin fixed, paraffin embedded tissues, i.e. MIB-1 ${ }^{20}$, Ki-S5 ${ }^{56}$ and a polyclonal Ki- $67{ }^{53}$. Numerous studies have shown a good correlation between $\mathrm{Ki}-67$ immunoreactivity and other indices of cell proliferation 7,91,104. Several investigators have found a correlation between a high number of Ki67-positive cells and the risk of recurrence or death in univariate analysis ${ }^{12,16}$. More recently it has been shown that high proliferative activity as measured by Ki67 antigen expression was an independent prognostic factor for survival ${ }^{16,50}$.

$P C N A$ or proliferating cell nuclear antigen is another frequently studied cell-proliferation associated antigen/cyclin. This $36 \mathrm{kDa}$ protein is an acidic nuclear protein which is a highly conserved, essential component of the replication machinery. It functions as an auxiliary protein for DNA polymerase $\delta$ in DNA synthesis ${ }^{14}$. PCNA expression begins in late $\mathrm{G}_{1}$ phase, peaks during $\mathrm{S}$ phase and decreases in $\mathrm{G}_{2}$ - and mitosis phase. It is localized to sites of DNA replication in $\mathrm{S}$ phase ${ }^{13}$. These studies also suggested that there are two populations of PCNA present during S phase. Nucleoplasmic PCNA corresponds to the PCNA present at low level in quiescent cells that are capable of cell division, and is not apparent in cells fixed in organic solvents such as methacarn. The second form of PCNA is associated with DNA replication sites and cannot be extracted with organic solvents ${ }^{15}$. Among the antibodies directed against PCNA , PC10 is a monoclonal antibody that does not require cryostat or fresh tissue sections but recognizes PCNA in formalin fixed, paraffin embedded material ${ }^{37,106}$. Immunoreactivity for $\mathrm{PC} 10$ has been shown to correlate with $\mathrm{Ki}-67$ staining in nodal lymphomas ${ }^{38}$ and with $\mathrm{S}+\mathrm{G}_{2} \mathrm{M}$-phase fraction as measured by flow cytometry in gastrointestinal lymphomas ${ }^{111}$. Woods et al found also in gastrointestinal lymphomas a correlation between the expression of PCNA and histological grading and prognosis: tumors with a high expression of PCNA tend to be high-grade lesions with a relatively poor prognosis.

\subsection{Differentiation and differentiation markers}

The ability of cells to differentiate in an orderly and controlled manner is of major importance for multicellular organisms, where all specialised cells are derived from a single totipotent cell. All somatic cells from an individual, with the exception of those that rearrange their antigen receptor genes (e.g. T- and B-lymphocytes) possess the same genome. While all the cells have the same genotype they differ in the expression of these genes. The phenotype of a cell is thus determined by the set of genes transcribed by that cell. As a result of this, cells differ in morphological and functional aspects. Developing and adult tissues are normally composed of integrated cell populations. Phenotypic variation within clonally derived progeny is a characteristic feature of normal tissues. An example of this is gut epithelium: three functional and morphological different compartments can be distinguished. First, in the crypt there is a basal compartment of continually renewing, stem cells, which give rise to the second compartment of differentiating, post-mitotic cells. Finally, when these cells reach the top of the villi they shed into the lumen and may undergo apoptosis.

Another example is the human mammary gland. Normal development and function of the breast is dependent on the coordinated action of various hormones (e.g. steroid hormones). In this organ a cyclic variation in differentiation can be found. With the onset of the menstrual 
cycle breast development commences. Next to growth and elongation of ducts, differentiation of hormonally responsive periductal stroma occurs at this time. Whereas the greatest amount of breast glandular differentiation occurs during puberty, the process may continue into the 20 s and is enhanced by pregnancy. The structural effects of cyclic menstrual changes are manifested by fluctuations in breast size and texture ${ }^{82}$. In general, during the proliferative phase (day 3-7) of the menstrual cycle the highest proliferative activity can be found in the mammary duct epithelium ${ }^{62}$. Also, the number of apoptotic cells is increased ${ }^{5}$. In the luteal phase (day 15-20), a peak incidence of apoptosis occurs ${ }^{84}$.

The steroid hormone receptor status of tumor specimens can have a prognostic implication; for example estrogen receptor positivity in human breast carcinoma carries a beneficial prognosis when compared to tumors with lesser or undetectable levels of receptor. Several authors ${ }^{1,28,71,85}$ have shown, that the presence and level of the receptor in a tumor is correlated with the response to endocrine therapy and with prognosis, as reflected in disease free interval and survival. Traditionally, an ER level of less than $10 \mathrm{fmol} / \mathrm{mg}$ cytosol protein has been used for ER-negative tumors. This cut-off point has however been questioned, while it has also been suggested that only patients with a very high ER level responds well after hormonal treatments. Clinical observations have shown that only $30 \%$ of all primary breast cancers regress after endocrine therapy ${ }^{79}$. Using immunohistochemical techniques a good correlation was found with the standard biochemical techniques ${ }^{27,52,68,73}$. This is a better method especially because direct visualization allows to distinguish tumor cells from normal cells, thus diminishing the frequency of false-negative results. However, the influence of the optimal cut-off point's still remains to be determined. Next to this, the immunohistochemical technique is susceptible to many factors that are hard to standardize. Another method for the detection of the steroid hormone receptors is flow cytometry ${ }^{88}$. However, the heterogeneous cell composition of most tumors is one of the limiting factors for this quantitative receptor assay. Multiparameter FCM analysis of cytokeratin, ER or PR, and DNA content facilitates the semiquantitative measurement of hormone receptors in the relevant subpopulation of cells by focussing on the epithelial cell population. Furthermore, receptor content can then be analyzed in relation to DNA ploidy and growth potential (as reflected in the SPF of the tumor cells). Both parameters have shown to be important prognostic parameters in some types of cancer ${ }^{81.103}$. However, this approach is mainly limited to prospective studies since fresh, unfixed tissue samples are normally required.

Immunophenotyping of cell surface differentiation antigens plays an important role in the diagnosis and classification of lymphoproliferative disorders. The expression of a particular set of antigenic epitopes designates a cell to a particular differentiation stage. Based on the expression of these epitopes hematopoietic differentiation schemes can be designed ${ }^{83}$. However, it should be realized that differentiation is a gradual process of events and that differentiation stages are not as finite as suggested. The detection of these epitopes with aid of flow cytometry in combination with immunological techniques has now become the preferred method for (1) lineage assignment, (2) maturational characterization of malignant cells, (3) detection of clonality, (4) detection of heterogeneity and abberant features of the malignant cell population, and (5) quantitation of hematopoietic cell population. However, this approach is again limited by the availability of fresh unfixed tissue, often presenting logistic problems in a routine setting. 


\subsection{Apoptosis}

Tissue homeostasis is maintained by a delicate balance between proliferation and cell death. Two typical forms of cell death can be distinguished: necrosis and apoptosis. In contrast to apoptosis, necrosis is a non-physiological way of cell death caused by severe toxic insults, such as by hypoxia; inhibition of oxidative phosphorylation, glycolysis or the Krebs cycle; hyperthermia; autolysis; complement and a variety of toxins ${ }^{65.113}$. Cell necrosis is characterised by swelling of the cells, their mitochondria dilate, other organelles dissolve, and plasma membranes rupture, whereas the nuclear changes are relatively unremarkable ${ }^{65,113}$. The subject of apoptotic cell death has recently seen a scientific revival in a variety of research fields. Apoptosis is a morphological distinct process of cell death that constitutes a means of cell suicide for the removal of unwanted cells ${ }^{92,112}$. It plays an important role during embryogenesis $^{118}$, removal of autoreactive T-lymphocytes in the adult thymus ${ }^{64}$ and destruction of target cells by natural killer cells and cytolytic T-lymphocytes ${ }^{22}$. It is the process, which culminates in the cessation of biological activity. At the moment it is difficult to define when a cell has passed the point of no return in the death process. In contrast to necrosis, no inflammatory response occurs and apoptotic bodies are phagocytosed very early by surrounding cells or phagocytes. A large number of stimuli can induce apoptosis in a cell type specific manner. General inducers are chemotherapeutic agents, ultraviolet and $\gamma$ irradiation, heat, osmotic imbalance, high calcium, and nitric oxide ${ }^{02}$. A selective induction on the other hand is seen, eg. in thymocytes that undergo massive apoptosis, when exposed to glucocorticoids ${ }^{24}$. Also, ablation of supply of a trophic factor or a growth hormone leads to apoptosis of only the target cells that harbor the receptor for these hormones ${ }^{23,109}$. After triggering apoptosis in individual cells, transcription of specific genes, as well as the activation of endogeneous endonucleases and caspases ${ }^{6,114}$ occurs. During apoptosis, cells shrink and dissociate from surrounding cells, organelles remain functional, the plasma membrane shows lipid assymetry and eventually loss of integrity, and the nucleus displays a distinctive pattern of heterochromatization and eventual fragmentation.

Irreversible commitment to apoptosis occurs with the activation of one or a group of mammalian cysteine proteases called caspases ${ }^{2}$. Caspases are expressed as proenzymes and are proteolytically activated. Caspases cleave carboxyl-terminal after an aspartic acid and generally recognize four amino acid substrate sites as their target ${ }^{60}$. Several proteins have been suggested as potential targets for caspase activity. Lazebnik et al ${ }^{59}$ showed that one member of the family of caspases is responsible for the specific breakdown of poly(ADP-ribose) polymerase (PARP). PARP is involved in DNA repair and genome integrity, an activity seen predominantly in response to treatment with DNA-damaging agents. Other known substrates for caspase activity are the $70 \mathrm{kDa}$ component of the U1 small ribonucleoprotein (U1-70 $\mathrm{kDa})^{101}, \operatorname{lamin}^{119}, \alpha$-fodrin ${ }^{66}, \operatorname{actin}^{67}$ and cytokeratin ${ }^{21}$. Due to the activity of these caspases neo-epitopes are generated which can serve as target for the development of new apoptosis detecting probes. Yang et al generated an antibody called fractin, which recognized the carboxyl-terminal end of a $32-\mathrm{kDa}$ actin fragment, produced by caspase-like activity. This antibody showed a positive immunoreaction in apoptotic but not necrotic or differentiated neuroblastoma cells in culture ${ }^{117}$

Many studies have shown that apoptotis is generally increased in cancer (for a review see Soini et $\mathrm{al}^{96}$ ). In most of those studies it was shown that occurence of apoptosis is not related to tumor stage, grade or progression. The hormone-dependent epithelial tumors and lymphomas in which a higher extent of apoptosis is associated with tumors of a higher grade 
form an exception. In general a high degree of tumor-dependent variability is seen. A possible cell biological explanation for apoptosis in tumors is the increased sensitivity to apoptosis of cells that have lost their matrix attachment or cell-cell contacts ${ }^{70}$. This could be due, for instance, to a loss of an expression of cell adhesion molecules from the surface of neoplastic cells, e.g. cadherins or integrins?

It should be possible to develop therapeutic agents to increase or decrease the susceptibility of particular cells to apoptosis. Drugs that promote apoptosis could amplify the effects of cancer chemotherapeutic agents on resistant cells. Caspases and the bcl-2 family could be targets of such agents. Apoptosis-preventing members of the bcl-2 family include bcl-2, bcl-xL, bcl-w, bfl-1, brag-1, mcl-1 and $\mathrm{Al}^{19,46,57,116}$. Apoptosis-promoting members are bax, bak, bcl-xS, bad, bid, bik and Hrk ${ }^{19,46,57,116}$. These families of proteins are resident proteins of the mitochondrial membranes, endoplasmic reticulum and nuclear envelope. They associate which each other to form homo- and/or heterodimers. Most studies that show a relationship between bcl-2 and apoptotic rates in tumors are limited to immunohistochemical approaches ${ }^{51}$. Steck and coworkers described a flow cytometric study of the relation between apoptosis and bcl- 2 in fresh tissue samples ${ }^{97,98}$. They found low apoptosis in a majority of tumors with high bcl-2 expression. This confirmed earlier findings that overexpression of bcl-2 blocks apoptosis in certain solid tumors ${ }^{45,69}$. In another flow cytometric study by the same group, they found in breast carcinomas a positive correlation between bcl-2 expression and positive expression of the estrogen receptor, DNA diploidy and low $\mathrm{S}+\mathrm{G}_{2} \mathrm{M}$ fractions. Together with other studies, these findings highlight the possible regulatory role of hormone receptors on bcl-2 expression in these tumors ${ }^{100,105}$.

Although recognized to be an essential component of the dynamics of tissue architecture for many years, the relative difficulty in assessing and quantitating apoptotic (programmed) cell death has substantially hindered its study in both normal and pathological processes. At this moment, the Terminal deoxynucleotidyl transferase mediated dUTP-biotin nick end labeling (TUNEL)-assay is the most widely used and established method to investigate apoptosis in tissue sections. This method makes use of the fact that during apoptosis endonucleolytic cleavage activity takes place in DNA. This cleavage results into the presence of 3'-OH-termini in DNA breaks. The TUNEL-assay is based on the addition of digoxygenin- or biotin-labeled deoxynucleotides to the $3^{\prime}-\mathrm{OH}$-termini and this process is catalyzed by the exogenously added enzyme TdT. The TUNEL-assay has proved to be particularly useful in formalin-fixed, paraffin embedded tissues after a short enzymatical digestion step (in most cases proteinase $\mathrm{K}$ is used for this purpose). However, care must be taken when interpreting these reactions because they are sensitive to a number of factors. Enzyme concentration (TdT or DNA polymerase) and duration of digestion (with e.g. proteinase K) are crucial for optimal staining. Increased polymerase- or TdT-activity results in the demonstration of much lower levels of DNA strand breaks, which could be caused artificially by fixation and processing, or even by cutting the section. Underdigestion yields false-negative results, whereas overdigestion produces false positive results and increased background staining. Diffuse background staining may also be present in severely necrotic tissues. Kockx et al found high values of TUNEL-positivity in regions which show signs of RNA transcription and splicing: both phenomenons are not related to apoptosis ${ }^{55}$. Besides this, they found also nonspecific binding of the nucleotides, used in the TUNEL assay, to small calcium containing vesicles in atherosclerotic plaques ${ }^{54}$. 


\section{Flow cytometry}

\subsection{Technical aspects}

\subsubsection{INTRODUCTION}

Tumors in general consist of more than one cell population, each with their own characteristics and behaviour. It is very difficult to investigate the different tumor cell populations by light microscopy, due to the admixture with non-relevant normal cells (e.g. inflammatory cells, stromal component etc). Flow cytometry is a technique, which can tackle these problems. Multiple parameters of the cell can be measured simultaneously and can be quantified.

Flow cytometers are instruments constructed to measure and record fluorescence. The basic components of a flow cytometer include a light source, a flow chamber and optical assembly (Fig. 2). The measurements are usually performed on cells stained with an appropriate fluorochrome, flowing past an excitation source. The fluorescence level of the stained cell is captured by a photomultiplier tube and digitally converted to an electronic pulse.

\subsubsection{THE LIGHT SOURCE}

A variety of light sources have been utilized in clinical flow cytometers. The most used are Arc sources (mercury compact arc lamp) and laser sources (continuos wave, argon-ion gas laser (UV, blue and green light), krypton ion gas laser (yellow and red light), helium-neon gas laser (red light) and the diode (red light) laser). Laser sources are principally used in modern flow cytometers. The advantages of a laser source are that they consists of a single color of light or an extremely narrow range of wavelengths. In addition, the waves comprising a laser beam are in 'phase'. As a result the beam of laser light is much more intense than that produced from incoherent light sources. The third advantage of laser light is directionality. The beam of light emerging from a laser is narrow and highly directional, while light from ordinary sources is emitted in all directions.

\subsubsection{THE FLOW CHAMBER}

The cells to be measured are introduced into the center of a fast moving fluid stream and forced to flow single file out of a 50-100 $\mu \mathrm{m}$ orifice at uniform speeds (typically $1-10 \mathrm{~m} / \mathrm{s}$ ). The particles are hydrodynamically constrained to the center of the stream by a surrounding layer of sheath fluid. The cells within the stream next pass a measurement station where they are illuminated by a light source. The point at which the laser beam and the cell stream meet is called the laser interrogation point (Fig. 2). Alignment is critical to successful operation of flow cytometers; suboptimal alignment can result in erroneous data collection, presentation, and interpretation. The newer clinical flow cytometers are constructed to reduce or eliminate the need for daily alignment.

\subsubsection{OPTICAL ASSEMBLY}

Once a cell passes the light beam two events will occur, assuming that fluorochromes are in or on the cell. The first event is that cells will scatter light from the beam at the incident wavelength in $360^{\circ}$. If one collects light scattered along the axis of the laser beam, a parameter known as forward angle light scatter, the quantity of the light is proportional to the size of the 
cell. If the scattered light is collected orthogonal at right angles to the light beam, the parameter is named $90^{\circ}$ light scatter, or side scatter. The side scatter has been shown to be composed primarily of light reflected by internal structures or membrane undulations. Therefore, this parameter correlates with cell granularity. The properties of forward and side scatter are called intrinsic properties because they can be measured by the flow cytometer without the use of exogenous reagents. Those properties requiring additional reagents for analysis are called extrinsic properties.

The second event that occurs at the laser interrogation point is that fluorochromes present on or in the cell absorb the laser light and re-emit the light at a lower energy and a longer wavelength. This property is known as fluorescence. Each fluorochrome possess a distinctive spectral pattern of excitation and emission. Typically, with argon-ion lasers, the excitation wavelength used is $488 \mathrm{~nm}$, a blue to blue-green light. The fluorochrome must also emit light at a wavelength sufficiently longer than the excitation wavelength so that the two colors of light may be optically separated with selective filters. The most popular fluorochromes used in immunofluorescence analysis are fluorescein isothiocyanate (FITC) and r-phycoerythrein (RPE). If multiple fluorochromes are used, their emission spectra must have minimal overlap so as to be separately quantitated.

The detection system of a flow cytometer consists of a variety of photocells, which collect light and convert it into integrated pulses. Because the burst of light from the particle lasts for only microseconds, the detector must be capable of rapidly processing signals from the detection zone, usually at a rate exceeding 10,000 pulses per second. Since the intensity of fluorescent light emitted by a cell is much less than that of light scatter signals, different types of photocells are used for each parameter. Photodiodes are used as detectors for light scatter signals while photomultiplier tubes are utilized to detect fluorescence light. The photomultiplier tube (PMT) both detect fluorescent signals and amplify the weak signals to a useful level. A schematic illustration of a typical flow cytometer is shown in figure 2.

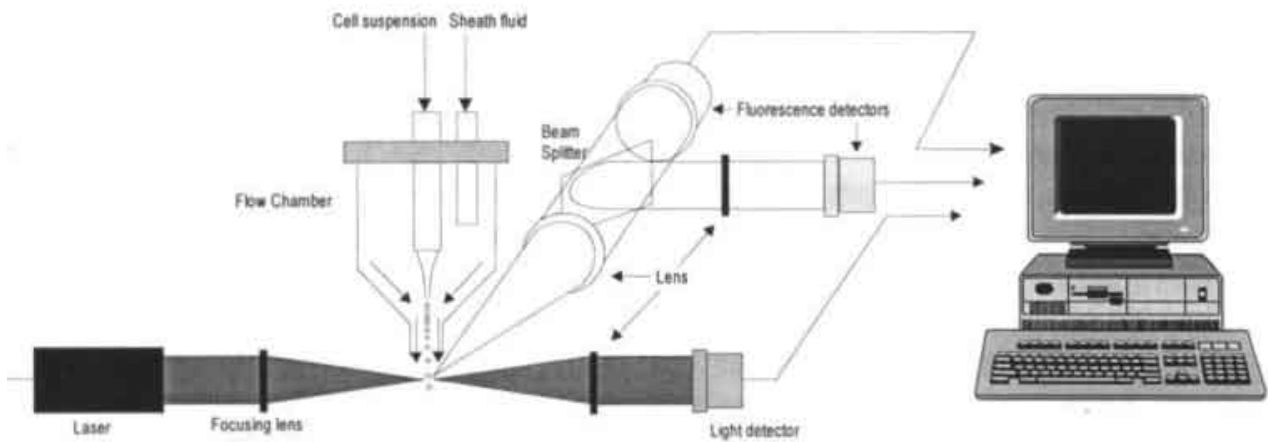

Optical assembly

Computer

Figure 2. Schematic principles of the flow cytometer 


\subsubsection{CELL PREPARATION METHODS}

Flow cytometric analysis requires a suspension of single cells. When analysing solid tumors, a cell suspension must be prepared by dissociating samples of fresh or formalin fixed, paraffin embedded tissues. Tumor dissociation involves the disruption of intercellular cohesion and the extracellular matrix. Four types of dissociation techniques (or combinations of these) can be distinguished. These include chemical, mechanical, enucleation and enzymatic dissociation techniques. There are several review articles and handbooks of flow cytometry in which the advantages and disadvantages of these techniques are described ${ }^{10,44,94}$.

For solid tumors an enzymatic dissociation technique is mostly used. Three categories of enzymes can be used: nonspecific proteases, proteases specific for elastic and collagenous fibers, and hydrolytic enzymes specific for mucopolysacharides. Examples of enzymes frequently used are trypsin and pepsin. Trypsin is a serine protease that hydrolyses peptide bonds involving carboxyl groups of arginine and lysine. Pepsin has a broad range of nonspecific proteolytic activities. Among the many cleavage sites, pepsin preferentially cleaves bonds between hydrophobic residues and the amino acids leucine, phenylalanine, methionine and tryptophan. In 1983, Hedley and his co-workers, developed an enzymatic dissociation technique for formalin fixed, paraffin embedded tissue using pepsin ${ }^{40}$. Two years later, Schutte et al introduced an enzymatic dissociation technique for paraffin embedded tissue based on a trypsin digestion step $^{87}$.

\subsubsection{DNA STAINING}

A major development in quantitative cytometry came with the discovery of a cytochemical stain specific for DNA ${ }^{32}$. In the early 1960 and 1970 the Feulgen technique was adapted for flow cytometry ${ }^{29}$. During the years several other DNA staining dyes (ethidium bromide, propidium iodide, acridine orange) seems to be more sensitive and easier to use. The most commonly used DNA-staining dyes are propidium iodide and ethidium bromide. Both shows intercalation between base pairs in double stranded DNA or RNA. When staining DNA for flow cytometric analysis, those DNA staining dyes are used under so-called equilibrium conditions, i.e. cells are resuspended in the dye solution, allowed to take up stain and analyzed by flow cytometry while suspended in dye solution. In theory, the fluorescence intensity of individual cells stained with DNA specific dyes is proportional to the DNA content of the cells. Therefore, for accurate quantitation, the dye must be used at a saturating concentration. However, it should be remembered that binding of dyes to DNA depends on chromatin confirmation. Only a portion of total DNA is ordinarily accessible to DNA binding fluorochromes $^{11.26}$, and accessibility may influenced by cell type, cell cycle phase, cell differentiation and cell viability. Next to this, blocking or an enzymatic digestion step is required for dyes which show nonspecific or unwanted staining reaction. For example, RNA must be removed by RNAse treatment when staining with propidium iodide, since this dye binds to both DNA and RNA. The spectral characteristics of propidium iodide make it a popular choice for flow cytometry, as it is readily excited by the $488 \mathrm{~nm}$ line of the argon-ion laser and it fluoresces with a maximum around $620 \mathrm{~nm}$ which makes it suitable for combination with FITC in multiparametric measurements.

Other DNA staining dyes are the ultraviolet excitated dyes Hoechst and DAPI. The Hoechst dyes act as DNA-specific fluorochromes when bound to sequences of three A-T base pairs in $\mathrm{DNA}^{75}$. DAPI (4'-6-diamidino-2-phenylindole) shows also a strong A-T preference. There are several reports which stated that DAPI yields DNA histograms with CV's lower than obtained 
using other dyes ${ }^{78}$. This lower CV is probably due to the fact that the DAPI-staining is less affected by the state of chromatin condensation than staining with other dyes ${ }^{26}$.

\subsection{The technique of flow cytometric DNA analysis}

Flow cytometric DNA analysis is the study of the distribution of DNA staining among the cells of a population ${ }^{36}$. These analyses provide clinicians with two potentially important cellular parameters of information. First, it gives a measurement of the fraction of cells which are in the S-phase of the cell cycle. Second, it provides information about the presence and degree of abnormal DNA content in the investigated cell population.
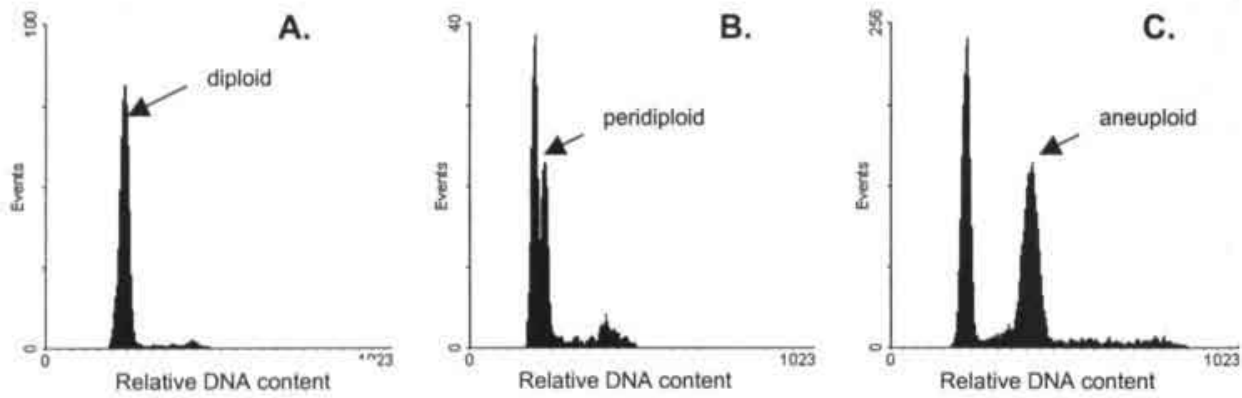

Figure 3. Examples of diploid (A.) and aneuploid (B. (peridiploid) and C. (real aneuploid)) DNA histograms

In normal tissue or a DNA diploid tumor, the great majority of cells are in the $\mathrm{G}_{0}$ or $\mathrm{G}_{1}$ phase and have a diploid DNA content. This is reflected in the DNA-histogram, which shows a single large peak of cells, the $\mathrm{G}_{0} / \mathrm{G}_{1}$-peak, with a $2 \mathrm{~N}$ DNA content. Normally a smaller peak of cells, which are in the $\mathrm{G}_{2}$ - and $\mathrm{M}$-phase of the cell cycle, is present on the $\mathrm{X}$-axis at double the distance of the $\mathrm{G}_{0} / \mathrm{G}_{1}$-peak $(4 \mathrm{~N})$. The compartment in between those two peaks is the Sphase fraction (SPF) with a DNA content between $2 \mathrm{~N}$ and $4 \mathrm{~N}$. In 1992 a DNA cytometry consensus conference was held, where a nomenclature for DNA cytometry was recommended ${ }^{93}$. For ploidy only the terms DNA diploid and DNA aneuploid should be used, with identification of the degree of DNA content abnormality given by the use of the DNAindex (DI). The DI is the ratio of mean or mode of sample $G_{0} / G_{1}$ population divided by mean or mode of diploid reference cells. The definition of DNA aneuploidy includes the requirement that two distinct peaks are present in the DNA histogram ${ }^{43}$. Furthermore it was stated that tumors with a DI of 2.0 (DNA 'tetraploidy') should be recorded separately as a distinct group of DNA aneuploidy, as they may have a distinct prognostic significance in some types of tumors (bladder, prostate). The working definition for DNA tetraploidy is DI values between 1.9 and 2.1 with proportions of cells greater than the $G_{2} M$ fraction of normal tissue samples, after correction for aggregates (see also Fig. 3). Many flow cytometric studies have used mainly the calculation of the proportion of cells in the S-phase of the cell cycle, to predict the clinical behaviour of human tumors. The assumption of these studies is that the fraction of cells, which synthesize DNA (S-phase fraction; SPF), is a direct reflection of tumor proliferation, and hence aggressive behavior ${ }^{10}$. However, the assessment of SPF by DNA flow 
cytometry encounters some limitations. In a lot of studies, the SPF could not be determined in considerable percentage of cases, because for technical reasons only some of the DNA histograms were suitable for analysis by these computer programs. Another possible danger is the underestimation of the SPF in DNA diploid or DNA peridiploid tumors. Solid tumors are in fact a heterogeneous admixture of benign (normal epithelial, stromal, endothelial and inflammatory cells) and malignant cells (viable, necrotic and apoptotic cells) ${ }^{25}$. Next to this, the malignant cells also show intratumoral heterogeneity in DNA content. All these factors adversely affect DNA ploidy and SPF determinations. Proliferating nonneoplastic cells have in general a lower SPF value than malignant cells causing an underestimation of SPF in DNA diploid or DNA peridiploid tumors ${ }^{30,41}$. Next to this, dilution by non-neoplastic cells impairs sensitivity for detection of minor aneuploid stemlines ${ }^{31,110}$.

\subsection{Multiparameter flow cytometric analyses}

One of the powers of flow cytometry is the ability to measure simultaneously several parameters on single cells. Ormerod et al showed that light scatter/volume measurements could help to distinguish normal from malignant nuclei isolated from paraffin sections, even when both are diploid ${ }^{77}$. To increase the accuracy of ploidy and cell cycle analysis, multiparameter flow cytometric techniques have been developed for single cell suspensions, prepared from fresh or fresh frozen tissue, by combining simultaneous staining for cytokeratin and DNA. Cytokeratins are epithelium-specific intermediate filament proteins expressed in normal and neoplastic conditions ${ }^{74}$. Exclusion of nonepithelial cells after selecting only the cytokeratin positive cells in a gated flow cytometric DNA histogram increases the accuracy of SPF and DNA index determination. Enkhardt and his co-workers showed after filtering out the non relevant fibroblasts and leukocytes that the SPF increased significantly in DNA-diploid tumors. Furthermore, they showed that some tumors were aneuploid whereas they were originally classified as DNA-diploid. Multiparameter flow cytometry could offer much more to clinical studies than simply helping to distinguish between normal and malignant cells. DNA content analysis can also be coupled to immunofluorescence staining of a variety of potentially biologically relevant cellular constituents to analyse tissue homeostasis and tumorbiodynamics. An example is the combined measurement of the expression of BrdU and $\mathrm{DNA}^{89}$. This technique can give kinetic information as well as measuring static indices of proliferation. In figure $\mathbf{4}$ an example of a multiparameter flow cytometric analysis of a breast carcinoma is shown. From this figure the power of selection of cell populations with different expression of a certain parameter becomes clear. When performing a DNA flow cytometric analysis, one has to exclude cell aggregates because these produce erroneous results. This can be done by electronic gating. In this technique, the signals of the width of the propidium iodide electronic pulses are displayed on the x-axis of a dotplot (e.g. fig. 4A), and the area of these pulses on the $y$-axis. Since single cells have a linear relationship between these parameters, cells in the $\mathrm{G}_{0 / 1}, \mathrm{~S}$ and $\mathrm{G}_{2} \mathrm{M}$ phases of the cell cycle fall on a diagonal line between the axes (Fig. 4A). A gate can be set (R1 in fig. 4A) along the diagonal to exclude cell doublets, based on the fact that cell doublets shows an increased width signs as compared to $\mathrm{G}_{2}$-phase cells. The DNA histogram of this tumor (Fig. 4B) showed two cell populations: a DNA diploid and an aneuploid one. In the next step the nonrelevant single cells (inflammatory cells, stromal compartment etc.) are excluded from the analysis. This is performed by 

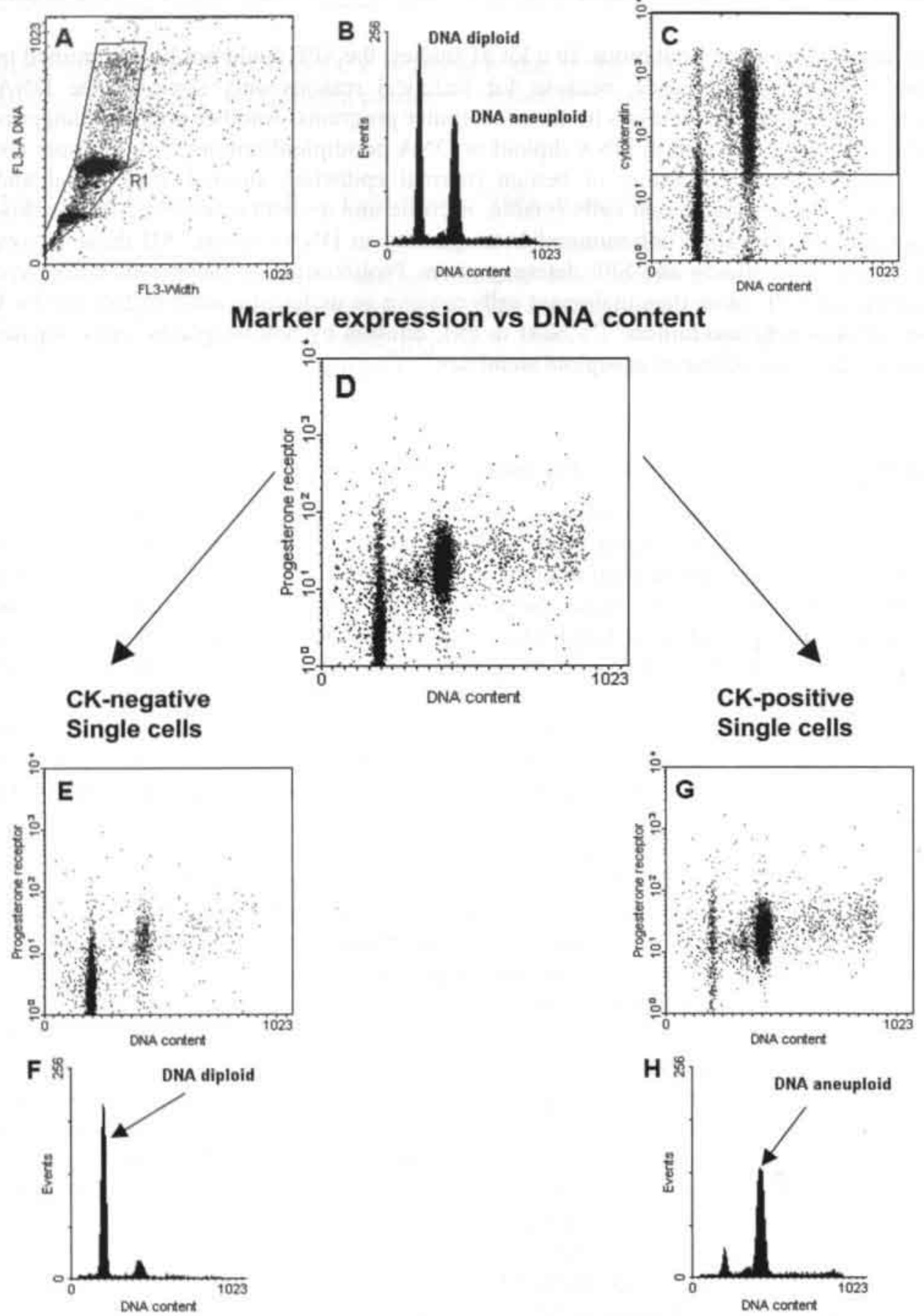

Figure 4. Example of a multiparameter flow cytometric cytokeratin/PR/DNA analysis of an aneuploid breast carcinoma (see text on page 21 for explanation; $C K=$ cytokeratin). Panel $A$ shows the selection of the single cells, while in panel B the DNA histogram of the ungated cells is depicted. Panel C and D shows the dotplot of DNA ( $x$-axis) vs cytokeratin ( $y$-axis) and DNA ( $x$-axis) vs. Progesterone receptor (PR; $y$ axis), respectively, for the total cell population. The solid lines in panel $\mathrm{C}$ and $\mathrm{D}$ denote the thresholds for immunoreactivity as determined based on the negative controls. Panel $\mathrm{E}$ and $\mathrm{F}$ shows the dotplot (DNA vs PR) and the DNA histogram, respectively, of the cytokeratin negative cells. Gating for cytokeratin positivity resulted in the dotplot (DNA vs PR) and DNA histogram as depicted in panel G and $\mathrm{H}$. 
selection of cytokeratin-positive cells. In a dotplot of DNA content (x-axis) vs. cytokeratin signal (y-axis) a region is set around the cytokeratin-positive cells (Fig. 4C; upperpart of the dotplot R2). The cut-off value for determining the treshold for immunoreactivity is based on ground of the negative control (a single cell suspension incubated with a nonrelevant immunoglobulin). Figure 4D shows a dotplot of DNA content ( $x$-axis) vs the expression of the progesterone receptor ( $\mathrm{y}$-axis) of the total single cell population. Figure $4 \mathrm{E}$ and $4 \mathrm{~F}$ showed the dotplot (of DNA content vs PR-expression) and DNA histogram, respectively, for the cytokeratin-negative cell population (all cells which are excluded from region R2 from fig. $4 \mathrm{C}$ ). From these figures it becomes clear that this compartment comprises almost only the DNA diploid cell population, while the DNA aneuploid population is found in the cytokeratinpositive selection (Fig. 4G and 4H; all cells which are situated in region R2 of figure 4C). Here also the highest immunoreactivity for the progesterone receptor is found. This example showed that by using more than one parameter simultaneously, plus the possibility of making selections based on the differential expression of markers, a more defined and possibly a more reliable quantification can be performed in the cell population of interest.

\subsection{Tissue material}

The above sample shows that multiparameter FCM analysis allows to quantify cellular parameters in the relevant, i.e. malignant subpopulation of cells. In almost all surgical pathology laboratories most of the material is routinely processed for formalin fixation and paraffin embedding. As mentioned before, the use of fresh material offers logistic problems in a routine setting. The use of fresh material has also other drawbacks: the danger of biohazardous contamination and the long time period which is needed to collect material when performing a study in rare tumors. Next to this, in a routine setting standardization of the technique on fresh material confronts the investigator with several problems. On the other hand, routinely processed formalin fixed, paraffin embedded material has the advantages that retrospective studies can be performed easier because of the huge archives of paraffin embedded material in almost each routine pathology laboratory. In addition, the use of paraffin embedded tissue allows the evaluation of the routinely made H\&E stained section so that the investigator is informed about the possible admixture with other tissues. Using this section, the investigator can decide to perform microdissection in case of extensive admixture with non-relevant tissue. So, the preferred method of analysis would be that of single cell suspensions prepared from formalin fixed, paraffin embedded material. It is well known that enzymatic digestion may have deleterious effects on tumor cells. Factors that play a role in this respect are type and concentration of the enzyme, size of tissue sample, the medium and its $\mathrm{pH}$, and the duration and temperature of digestion. All these factors have to be optimized to maximize cell yield while ensuring retention of the parameters to be investigated. Another factor, which influences the quality of the flow cytometric analysis is the duration and type of fixation of the tissue $e^{42.80}$. So far no attempts have been undertaken to develop methods for retrieval of cells from formalin fixed and paraffin embedded tissue blocks that would allow high resolution DNA flow cytometry in combination with the reliable measurement of antigen expression. 


\section{Aim of the present study}

The aims of this thesis can be summarized as follows:

A) Development of methodology to perform multiparameter DNA flow cytometry on formalin fixed, paraffin embedded tissues

With emphasis on:

- high yield of single cell preparation

- high resolution DNA and SPF analysis

- selection of relevant subtypes of cells

- (semi)quantitative measurements of marker expression pattern

B) Applicability of multiparameter flow cytometric approaches in a routine diagnostic setting:

Application of this new methodology in clinically relevant questions, which include:

- detection and quantification of Ki67-epitope

- quantification of the steroid hormone receptors in the epithelial compartment of breast cancer

- clonality assessment of lymphoproliferative disorders

- detection of, and studying the apoptotic process

\section{References}

1. Allegra JC, Lippman ME, Thompson EB, Simon R, Bablock A, Green L, Hoff KK, Po HMT, Iatkers SG, Warren R. Estrogen receptor status: an important variable in predicting response to endocrine therapy in metastatic breast cancer. Eur J Cancer 1980; 16: 323-331

2. Alnemri E. Mammalian cell death proteases: a family of highly conserved aspartate specific cysteine proteases. J Cell Biochem 1997; 64: 33-42

3. Amadori D, Volpi A, Maltoni R, Nanni O, Amaducci L, Amadori A, Giunchi DC, Vio A, Saragoni A, Silvestrini R. Cell proliferation as a predictor of response to chemotherapy in metastatic breast cancer: a prospective study. Breast Cancer Res Treat 1997; 43: 7-14

4. Amadori D, Silvestrini R. Prognostic and predictive value of thymidine labelling index in breast cancer. Breast Cancer Res Treat 1998; 51: 267-281

5. Anderson TJ, Ferguson JP, Raab GM. Cell turnover in the "resting"human breast: influence of parity, contraceptive pill, age and laterality. $\mathrm{Br} \mathrm{J}$ Cancer $1982 ; 46: 376-382$

6. Arends MJ, Morris RG, Wyllie AH. Apoptosis. The role of endonuclease. Am J Pathol 1990; 136: 593-608

7. Baisch J, Gerdes J. Simultaneous staining of exponentially growing versus plateau phase cells with the proliferationassociated antibody $\mathrm{Ki}-67$ and propidium iodide: analysis by flow cytometry. Cell Tissue Kinet 1987; 20:387-391

8. Banin S, Moyal L, Shieh S, Taya Y, Anderson CW, Chessa L, Smorodinsky NI, Prives C, Reiss Y, Shiloh Y, Ziv Y. Enhanced phosphorylation of p53 by ATM in response to DNA damage. Science 1998; 281: 1674-1677

9. Bates RC, Lincz F, Burns GF. Involvement of integrins in cell survival. Cancer Metastatis Rev 1995; 14: 191-203

10. Bauer KD, Duque RE, Shankey TV (eds). Clinical flow cytometry, principles and application. Baltimore, Williams \& Wilkins, 1993

11. Bertuzzi A, D'Agnano I, Gandolfi A, Craziano A, Starace G, Ubezio P. Study of propidium iodide binding to DNA in intact cells by flow cytometry. Cell Biophys 1990; 17:257-267

12. Bouzubar N, Walker RJ, Griffiths K, Ellis IO, Elston CW, Robertson JF, Blamey RW, Nicholson RI. Ki67immunostaining in primary breast cancer: pathologic and clinical associations. Br J Cancer 1989; 59:943-947

13. Bravo R, MacDonald-Bravo H. Changes in the nuclear distribution of cyclin (PCNA) but 7 not its synthesis depend on DNA replication. EMBO J 1985; 4: 655-661

14. Bravo R, Frank R, Blundell PA, Macdonald-Bravo H. Cyclin/PCNA is the auxiliary protein of DNA-polymerase $\delta$. Nature 1987; 326: 515-517

15. Bravo R, MacDonald -Bravo H. Existence of two populations of cyclin/proliferating cell nuclear antigen during the cell cycle: association with DNA replication sites. J Cell Biol 1987; 105: 1549-1554 
16. Brown RW, Allred DC, Clark GM, Osborne CK, Hilsenbeck SG. Prognostic value of Ki67 compared to S-phase fraction in axillary node-negative breast cancer. Clin Cancer Res 1996; 2: 585-592

17. Bruno S, Darzynkiewicz Z. Cell cycle dependent expression and stability of the nuclear antigen detected by the Ki-67 antibody in HL-60 cells. Cell Prolif 1992; $25: 31-40$

18. Canman CE, Lim DS, Cimprich KA, Taya Y, Tamai K, Sakaguchi K, Appella E, Kastan MB, Siliciano JD. Activation of the ATM kinase by ionizing radiation and phosphorylation of p53. Science 1998; 281: 1677-1679

19. Castedo M, Hirsch T, Susin SA, Zamzani M, Marchetti P, Macho A, Kroemer G. Sequential acquisition of mitochondrial and plasma membrane alterations during early lymphocyte apoptosis. J Immunol 1996; 157:512-521

20. Cattoretti G, Becker MHG, Key G, Duchrow M, Schlüter C, Galle J, Gerdes J. Monoclonal antibodies against recombinant parts of the Ki-67 antigen (MIB-1 and MIB-3) detect proliferating cells in microwave-processed formalin-fixed paraffin sections. J Pathol 1992; 168: 357-363

21. Caulin C, Salvesen GS, Oshima RG. Caspase cleavage of keratin 18 and reorganization of intermediate filaments during epithelial apoptosis. J Cell Biol 1997; 22: 379-394

22. Cohen JJ, Duke RC, Fadok VA, Sellins KS. Apoptosis and programmed cell death in immunity. Annu Rev Immunol 1992; 10: 267-293

23. Colombel M, Olsson CA, Ng P-Y, Buttyan R. Hormone-regulated apoptosis results from reentry of differentiated prostate cells onto a defective cell cycle. Cancer Res 1992; 52: 4313-4319

24. Cory S. Regulation of lymphocyte survival by the bel-2 gene family. Annu Rev Immunol 1995: 13: 513-543

25. Crissman JD, Zarbo RJ, Ma CK, Visscher DW. Histopathological parameters and DNA analysis in colorectal adenocarcinomas. Path Annual 1989; 24(II): 103-147

26. Darzynkiewicz Z, Traganos F, Kapuscinski J, Staiano-Coico L, Melamed MR. Accessibility of DNA in situ to various fluorochromes: relationship to chromatin changes during erythroid differentiation of Friend leukemia cells. Cytometry 1984; $5: 355-363$

27. De Lena M, Marzullo F, Simone G, Labriola A, Tommasi S, Petroni S, Paradiso A. Correlation between ERICA and DCC assay in hormone receptor assessment of human breast cancer. Oncology $1988 ; 45: 308-312$

28. DeSombre ER. Breast Cancer: hormone receptors, prognosis and therapy. Clin Oncol 1982; 1: 191-213

29. Dilla v MA, Trujillo TT, Mullaney PF, Coulter JR. Cell microfluorometry: a method for rapid fluorescence measurement. Science 1969; 163:1213-1214

30. Dressler LG, Seamer L, Owens MA, Clark GM, MeGuire WL. DNA flow cytometry and prognostic factors in 1331 frozen breast cancer specimens. Cancer 1988; 61: 420-427

31. Frei JV, RizkallaK, Martinez VJ. Proliferative cell indices measured by DNA flow cytometry in node negative adenocarcinomas of breast: accuracy and significance in cytokeratin-stained archival specimens. Mod Pathol 1994; 9 : 925-929

32. Feulgen R, Rossenbeck H. Mikroskopisch-chemischer nachweis einer nucleinsäure von typus der Thymonnucleinsäure und die darauf beruhende elektive Färbung von Zellkerne in mikroskopischen Präparaten. Z Physiol Chem 1924; 135: 203-224

33. Gerdes J, Schwab U, Lemke H, Stein H. Production of a mouse monoclonal antibody reactive with a human nuclear antigen associated with cell proliferation. Int J Cancer 1983;31:13-20

34. Gerdes J, Lemke H, Baisch H, Wacher H-H, Schwab U, Stein H. Cell cycle analysis of a cell proliferation-associated human nuclear antigen defined by the monoclonal antibody Ki-67. J Immunol 1984; 133: 1710-1715

35. Gerdes J, Li L, Schlüter C, Duchrow M, Wohlenberg C, Gerlach C, Stahmer I, Kloth S, Brandt E, Flat HD. Immunobiochemical and molecular biological characterization of the cell proliferation-associated nuclear antigen that is defined by monoclonal antibody Ki-67. Am J Pathol 1991; 138:867-873

36. Gray JW, Dolbeare F, Pallavicini MG, Beisker W, Waldman F. Cell cycle analysis using flow cytometry. Int J Radiat Biol Relat Stud Phys Chem Med 1986; 49: 237-255

37. Hall PA, Levison DA, Woods AL, Yu CCW, Kellok DB, Watkins JA, Barnes DM, Gillet CE, Camplejohn R, Dover R, Wasseem NH, Lane DP. Proliferating cell nuclear antigen (PCNA) immunolocalization in paraffin sections: an index of cell proliferation with evidence of deregulated expression in some neoplasms. J Pathol 1990a: 162; 285-294

38. Hall PA, Levison DA. Assessment of cell proliferation in histological material. J Clin Pathol 1990b; 43: 184-192

39. Hall PA, Lane DP. Genetics of growth arrest and cell death: Key determinants of tissue homeostasis. Eur J Cancer 1994; 30: 2001-2012

40. Hedley DW, Friedlander ML, Taylor IW, Rugg CA, Musgrove EA. Method for analysis of cellular DNA content of paraffin-embedded pathological material using flow cytometry. J Histochem Cytochem 1983; 31: 1333-1335

41. Hedley DW, Rugg CA, Gelber RD. Association of DNA index and S-phase fraction with prognosis of node-positive early breast cancer. Cancer Res 1987; 47: 4729-4735

42. Hedley DW. Flow cytometry using paraffin-embedded tissue: five years on. Cytometry 1989; 10: 229-241

43. Hiddemann W, Schumann J, Andreeff M, Barlogie B, Herman CJ, Leif RC, Mayall BH, Murphy RF, Sandberg AA. Convention on nomenclature for DNA cytometry. Cytometry 1984; 5: 445-446 
44. Hitcheock CL, Ensley JF. Technical considerations for dissociation of fresh and archival tumors. Chapter 6 in Clinical flow cytometry, principles and application. Bauer KD, Duque RE, Shankey TV (eds). Baltimore, Williams \& Wilkins, 1993

45. Hockenberry D, Nunez G, Milliman C, Schreiber RD, Korsmeyer SJ. Bcl-2 is an inner mitochondrial membrane protein that blocks programmed cell death. Nature 1990; 348: 334-336

46. Hockenberry DM. Bcl-2 in cancer, development and apoptosis. J Cell Sci 1995; 18: 51-55

47. Hollstein M, Sidransky D, Vogelstein B, Harris CC. P53 mutations in human cancers. Science 1991; 253: 49-53

48. Hunter T, Pines J. Cyclins and cancer. Cell 1991; 66: 1071-1074

49. Hunter T, Pines J. Cyclins and cancer II. Cyclin D and CDK inhibitors come of age. Cell 1994; 79:573-582

50. Jensen V, Ladekarl M, Holm-Nielsen P, Melsen F, Soerensen FB. The prognostic value of oncogenic antigen 519 (OA-519) expression and proliferative activity detected by antibody MIB-1 in node-negative breast cancer. J Pathol $1995 ; 176: 343-352$

51. Joensuu H, Pylkkanen L, Toikkanen S. Bcl-2 protein expression and long term survival in breast cancer. Am J Pathol 1994; 145: 1191-1198

52. Katz RL, Patel S, Sneige N, Fritsche HA, Hortobagyi GN, Ames FC, Brooks T, Ordonez NG. Comparison of immunocytochemical and biochemical assays for estrogen receptor in fine needel aspirates and histological sections from breast carcinomas. Breast Cancer Res Treat 1990; 15: 191-203

53. Key G, Larsen Petersen J, Becker MHG, Duchrow M, Schlüter C, Askaa J, Gerdes J. New antiserum against Ki-67 antigen suitable for double immunostaining of paraffin wax sections. J Clin Pathol 1993; 46: 1080-1084

54. Kockx MM, Muhring J, Bortier H, De Meyer GRY, Jacob W. Biotin- or digoxigenin-conjugated nucleotides bind to matrix vesicles in atherosclerotic plaques. Am J Pathol 1996; 148: 1771-1777

55. Kockx MM, Muhring J, Knaapen MWM, De Meyer GRY. RNA synthesis and splicing interferes with DNA in situ end labeling techniques used to detect apoptosis. Am J Pathol 1998; 152: 885-888

56. Kreipe H, Wacker H-H, Heidebrecht HJ, Haas K, Hauberg M, Tiemann M, Parwaresch R. Determination of the growth fraction in non-Hodgkin's lymphomas by monoclonal antibody Ki-S5 directed against a formalin-resistant epitope of the Ki-67 antigen. Am J Pathol 1993; 142: 1689-1694

57. Kroemer G. The proto-oncogene bel-2 and its role in regulating apoptosis. Nat Med 1997; 3: 614-620

58. Lajtha LG. On the concept of the cell cycle. J Cell Comp Phys 1963; 62: 143-145

59. Lazebnik YA, Kaufmann SH, Desnoyers S, Poirier GG, Earnshaw WC. Cleavage of poly(ADP-ribose)polymerase by a proteinase with properties like ICE. Nature 1994; $371: 346-347$

60. LeBlanc A. Detection of actin cleavage in Alzheimer's disease. Am J Pathol 1998; 152: 329-332

61. Li R, Naga S, Hannon GJ, Beach D, Stillman B. Different effects of the p21 CDK inhibitor on PCNA-dependent DNA replication and repair. Nature 1994; 371 : 534-537

62. Longacre TA, Bartow SA. A correlative morphological study of human breast and endometrium in the menstrual cycle. Am J Surg Pathol 1986; 10: 382-393

63. Lowe SW, Bodis S, McClatchey A, Remington L, Ruley HE, Fisher DE, Housman DE, Jacks T. P53 status and the efficiacy of cancer therapy in vivo. Science $1994 ; 266: 807-810$

64. MacDonald HR, Lees RK. Programmed cell death of autoreactive thymocytes. Nature 1990; 343: 642-644

65. Majno G, Joris I. Apoptosis, oncosis and necrosis. An overview of cell death. Am J Pathol 1995; 146: 3-15

66. Martin SJ, O'Brien GA, Nishioka WK, McGahon AJ, Mahboubi A, Saido TC, Green DR. Proteolysis of fodrin (nonethryoid spectrin) during apoptosis. J Biol Chem 1995; 270: 6425-6428

67. Mashima T, Naito M, Noguchi K, Miller D, Nicholson D, Tsuruo T. Actin cleavage by CPP-32/apopain during the development of apoptosis. Oncogene 1997; 14: 1007-1012

68. McCarty KS Jr, Miller LS, Cox EB, Konrath J, McCarty KS Sr. Estrogen receptor analyses, correlation of biochemical and immunohistochemical methods using monoclonal antireceptor antibodies. Arch Path Lab Med 1985; 109: $716-721$

69. McDonnel TJ, Deane N, PlattFM, Nunez G, Jaeger U, McKearn JP, Korsmeyer SJ. Bcl-2 immunoglobulin transgenic mice demonstrate extended B cell survival and follicular lymphoproliferation. Cell 1989; $57: 79-88$

70. McGill G, Shimamura A, Bates RC, Savage RE, Fisher DE. Loss of matrix adhesion triggers rapid transformationselective apoptosis in fibroblasts. J Cell Biol 1997; 138: 901-911

71. McGuire WL. Prognostic factors in primary breast cancer. Cancer Surv 1986; 203:527-536

72. Meyer JS, Province MA. S-phase fraction and nuclear size in long term prognosis of patients with breast cancer. Cancer $1994 ; 74: 2287-2299$

73. Molino A, Micciolo R, Turazza M, Bonetti F, Piubello Q, Corgnati A, Sperotto L, Martignoni G, Bonetti A, Nortilli $\mathrm{R}$ et al. Estrogen receptors in 699 primary breast cancers: a comparison of immunohistochemical and biochemical methods. Breast Cancer Res Treat 1995; 34: 221-28

74. Moll R, Franke WW, Schiller DL. The catalog of human cytokeratins: patterns of expression in normal epithelia, tumors and cultured cells. Cell 1982;31: 11-24

75. Müller W, Gautier F. Interactions of heteroaromatic compounds with nucleid acids. A-T specific non-intercalating DNA ligands. Eur J Biochem 1975; 54: 385-394 
76. Musgrove EA, Lee CLE, Buckley MF, Sutherland RL. Cyclin Dlinduction in breast cancer cells shortens the G1 and is sufficient for cells arrested in G1 to complete the cell cycle. Proc Natl Acad Sci USA 1994; 91 : 8022-8026

77. Ormerod MG, Titley JC, Imrie PR. Use of light scatter when recording a DNA histogram from paraffin-embedded tissue. Cytometry 1995; 21: 294-299

78. Otto F, Tsou KC. A comparative study of DAPI, DIPI, and Hoechst 33258 and 33342 as chromosomal DNA stains. Stain Technol 1985; 60: 7-11

79. Paridaens RJ, Leclercq G, Piccart MJ, Kiss R, Mattheiem WH, Heusin JC. Comments on the treatment of breast cancer. Cancer Surv 1986; 5: 447-461

80. Price J, Herman CJ. Reproducibility of FCM DNA content from replicate paraffin block samples. Cytometry 1990; 11: $845-847$

81. Ritchie AW, Dorey F, Layfield LJ, Hannah J, Lovrekovich H, deKemion JB, Relationship of DNA content to conventional prognostic factors in clinically localised carcinoma of the prostate. Br JUrol 1988; 62: 245-260

82. Rosen PP. Rosen's Breast Pathology. Lipincott-Raven Publishers, Philadelphia, Pensylvania, 1997

83. Rothe G, Schmitz G, Adorf N, Barlage S, Gramatzki M, Hanenberg H, Höffkes HG, Janossy G, Knüchel R, Ludwig WD, Nebe T, Nerl C, Orfao A, Serke S, Sonnen R, Tichelli A, Wörmann B. Consensus protocol for the flow cytometric immunophenotyping of hematopoietic malignancies. Leukemia 1996; 10: 877-895

84. Sabourin J, Martin A, Baruch J Truc JB, Gompel A, Poitout P. Bcl-2 expression in normal breast during the menstrual cycle. Int J Cancer 1994; 59: 1-6

85. Saez S, Pichon MF, Cheix F, Mayer M, Pallud C, Brunet M, Milgrom E. Progesterone receptors and prognosis in early breast cancer. The experience of two authors. In: Bardin CW, Milgrom E, Mauvais P, Jarvis (Eds). Progesterones and progestines: $355-366$

86. Sasaki M, Murakami R, Kawasaki M, Takahashi M. The cell cycle associated change of the Ki-67 reactive nuclear antigen expression. J Cell Physiol 1987; 133: 579-584

87. Schutte B, Reynders MMJ, Bosman FT, Blijham GH. Flow cytometric determination of DNA ploidy level in nuclei isolated from paraffin embedded tissue. Cytometry $1985 ; 6: 26-30$

88. Schutte B, Scheres HME, De Goeij AFPM, Rousch MJM, Blijham GH, Bosman FT, Ramaekers FCS. Flow cytometric steroid receptor analysis. Progress Histo Cytochem 1992; 26: 68-76

89. Schutte B, Tinnemans MMFJ, Pijpers GFP, Lenders MHJH, Ramaekers FCS. Three parameter flow cytometric analysis: simultaneous detection of cytokeratin, proliferation associated antigens and DNA content. Cytometry 1995; 21: $177-186$

90. Schuuring E, Verhoeven E, Mooi WJ, Michalides RJAM. Identification and cloning of two overexpressed genes, U21B31/PRAD1 and EMS1, within the amplified chromosome 11q13 region in human carcinomas. Oncogene 1992; 7: $355-361$

91. Schwarting R, Gerdes J, Niehus J, Jaesche L, Stein H. Determination of the growth fraction in cell suspensions by flow cytometry using the monoclonal antibody Ki-67. J Immunol Methods 1986; 90: 365-371

92. Schwartzman RA, Cidlowski JA. Apoptosis: the biochemistry and molecular biology of programmed cell death. Endocrine Rev 1993; 14: 1336-151

93. Shankey TV, Rabinovitch PS, Bagwell B, Bauer KD, Duque RE, Hedley DW, Mayall BH, Wheeles L. Guidelines for implementation of clinical DNA cytometry. Cytometry 1993; 14:472-477

94. Shapiro HM. Practical flow cytometry. 3th ed. Wiley-Liss, Inc. New York, USA

95. Smith ML, Chen IT, Zhan Q, Bae I, Chen CY, Gilmer TM, Kastan MB, O'Connor PM, Fornace AJ Jr. Interaction of the p53-regulated protein GADD45 with proliferating cell nuclear antigen. Science $1994 ; 266: 1376-1380$

96. Soini Y, Päảkkö P, Lehto VP. Histopathologic evaluation of apoptosis in cancer. Am J Pathol 1998; 153: $1041-1053$

97. Steck KD, McDonnell TJ, El-Naggar AK. Flow cytometric analysis of apoptosis and bcl-2 in human solid neoplasms. Cytometry 1995; 20: 154-163

98. Steck KD, McDonnell T, Sneige N, El-Naggar A. Flow cytometric analysis of apoptosis and bcl-2 in primary breast carcinomas: clinical and biological implications. Cytometry 1996; 24: 116-122

99. Taylor \& Cote. Immunomicroscopy: a diagnostic tool for the surgical pathologist. 2nd ed. W.B. Saunders \& Company, Philadelphia, USA 1994

100. Teixeira C, Reed JC, Pratt Mac. Estrogen promotes chemotherapeutic drug resistance by a mechanism involving bcl2 proto-oncogene expression in human breast cancer cells. Cancer Res 1995; $55: 3902-3907$

101. Tewari M, Beidler DR, Dixit VM. CrmA-inhibitable cleavage of the 70-kDa protein component of the U1 small nuclear ribonucleoprotein during FAS- and Tumor Necrosis Factor-induced apoptosis. J Biol Chem 1995; 270: $18738-18741$

102. Thompson CB. Apoptosis in the pathogenesis and treatment of disease. Science $1995 ; 267: 1456-1462$

103. Visakorpi T, Kallioniemi OP, Paronen IY, Isola JJ, Heikkinen AI, Koivula TA. Flow cytometric analysis of DNA ploidy and S-phase fraction from prostatic carcinomas: implications for prognosis and response to endocrine therapy. Br J Cancer 1991; 64: 578-582

104. Walker RA, Camplejohn RS. Comparison of monoclonal antibody Ki-67 reactivity with grade and DNA flow cytometry of breast carcinomas. Br J Cancer 1988; 57: 281-283 
105. Wang TTY, Phang JM. Effects of estrogen on apoptotic pathways in human breast cancer cell line MCF-7. Cancer Res 1995; 55: 2487-2489

106. Wasseem NH, Lane DP. Monoclonal antibody analysis of the proliferating cell nuclear antigen (PCNA). Structural conservation and the detection of a nuclear form. J Cell Sci 1990; 96: 121-129

107. Wersto RP, Herz F, Callagher RE, Koss LG. Cell-cycle dependent reactivity with the monoclonal antibody Ki-67 during myeloid differentiation. Exp Cell Res 1988; 179: 79-88

108. Withers DDA, Harvey RC, Faust JB, Melnyk O, Carey K, Meeker TC. Characterization of a candidate bcl-1 gene. Moll Cell Biol 1991; 11: 4846-4853

109. Wilson JW, Wakeling AE, Morris ID, Hickman JA, Dive C. MCF-7 human mammary adenocarcinoma cell death in vitro in response to hormone-withdrawal and DNA-damage. Int J Cancer 1995; 61: 502-508

110. Wingren S, Stal O, Sullivan S, Brisfors A, Nordenskjold B. S-phase fraction after gating on epithelial cells predicts recurrence in node-negative breast cancer. Int J Cancer 1994; 59: 7-10

111. Woods AL, Hall PA, Shepherd NA, Hanby AM, Wasseem NH, Lane DP, Levison DA. The assessment of proliferating cell nuclear antigen (PCNA) immunostaining in primary gastrointestinal lymphomas and its relationship to histological grade, $\mathrm{S}+\mathrm{G}_{2} \mathrm{M}$ phase fraction (flow cytometric analysis) and prognosis. Histopathol 1991; 19: 21-27

112. Wyllie AH, Kerr JFR, Currie AR. Cell death: the significance of apoptosis, Int Rev Cytol 1980; 68: 251-306

113. Wyllie AH. Cell death: a new classification separating apoptosis from necrosis. In "Cell death in biology and pathology", ed. I Davies, DC Sigee, London: Cambridge Univ Press 1981, pp 269-294.

114. Wyllie AH. Apoptosis, Br J Cancer 1993; 67: 205-208

115. Xiong Y, Hannon GJ, Zhang H, Casso D, Kobayashi R, Beach D. p21 is an universal inhibitor of cyclin kinases. Nature 1993; 366: 401-404

116. Yang E, Korsmeyer SJ. Molecular thanatopsis: a discourse on the bcl-2 family and cell death. Blood 1996; 88: 386401

117. Yang F, Sun X, Beech W, Teter B, Wu S, Sigel J, Vinter HV, Frautschy SA, Cole GM. Antibody to caspase-cleaved actin detects apoptosis in differentiated neuroblastoma and plaque-associated neurons and microglia in Alzheimer's disease. Am J Pathol 1998; 152: 379-389

118. Zakeri Z, Quaglino D, Singh Ahuja H. Apoptotic cell death in the mouse limb and its suppression in the Hammertoe mutant. Dev B̄iol 1994; 165 : $294-297$

119. Zhivotovsky B, Gahm A, Ankarcrona M, Nicotera P, Orrenius S. Multiple proteases are involved in thymocyte apoptosis. Exp Cell Res 1995; 221: 404-412 


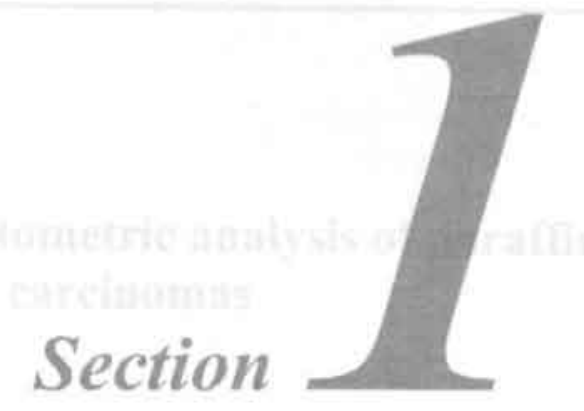

\section{Technical Developments}





\section{Bivariate cytokeratin/DNA flow cytometric analysis of paraffin embedded samples from colorectal carcinomas}

M.P.G. LEERS ${ }^{1}$, P.H.M.H. THEUNISSEN ${ }^{1}$, B. SCHUTTE ${ }^{2}$, F.C.S RAMAEKERS ${ }^{2}$

'Department of Pathology, De WeVer Hospital, HeERlen and ${ }^{2}$ Department of Molecular Cell Biology \& GENETICS, UNIVERSITY OF LIMBURG, MAASTRICHT, THE NETHERLANDS 


\begin{abstract}
Admixture of normal and neoplastic cells is a serious problem in the evaluation of tumor cell kinetic parameters by flow cytometry, in particular for DNA diploid tumors. The admixture of non-neoplastic cells, such as stromal cells and inflammatory cells, can disturb the estimation of the proliferative tumor fraction. This problem has been adressed for fresh tumor samples by applying bivariate flow cytometric analyses for DNA and cytokeratin (Zarbo et al, 1989). We have adapted this approach for formalin fixed and paraffin embedded tissue samples of colorectal carcinomas. After preparation of a single cell suspension from paraffin blocks by means of an enzymatic digestion step, the cells of epithelial origin were selectively stained with a panel of subtype specific cytokeratin antibodies. DNA analysis could thus be performed on the cytokeratin-positive cells. The proliferative fractions of the paraffin embedded samples could be compared with those of the fresh tissue samples, and a very good correlation was seen between DNA-indices from fresh and paraffin embedded material. As expected, after gating on the cytokeratin-positive cells an enrichment of the S-phase fraction was seen compared with the ungated cell population. However, this enrichment was more pronounced in the cell suspensions derived from the paraffin embedded part of the tumor as compared to the fresh disaggregated, ethanol fixed part of the tumor.
\end{abstract}

\title{
Introduction
}

Flow cytometric DNA analysis appears to have significant value for establishing prognosis and the response to therapy for several types of malignant tumors ${ }^{1,3,14,19}$. The method can be performed on fresh tissues or on formalin fixed, paraffin embedded tissue samples. One major limitation of flow cytometry is the requirement that the specimen to be analyzed must be in the form of a single cell suspension. In 1983 Hedley et al ${ }^{8}$ described a method for univariate analysis of DNA content in formalin fixed, paraffin embedded tissue by using an enzymatic digestion step of tissue with $0.5 \%$ pepsin at $\mathrm{pH} 1.5$.

However, solid tumors contain variable admixtures of non-tumor cells, including inflammatory cells, connective tissue cells and endothelial cells. Such mixed populations are in general not optimal for a proper cell cycle analysis. In fresh tissue samples it has been shown that the combined analysis of cytoplasmic markers (cytokeratin) and DNA may aid in the detection of small subpopulations of aneuploid cells that otherwise remained undetected. Secondly, cell cycle analysis of the relevant epithelial cell population can be performed without disturbance of stromal cells by gating for cytokeratin positivity. This approach has been applied with succes in a variety of tumor types, for example in bladder cancer ${ }^{5}$ and colorectal adenocarcinomas ${ }^{2,22}$.

We investigated whether, after enzymatic digestion of paraffin embedded tissue, cytokeratin was retained for immunocytochemical marking and subsequent flow cytometric analysis. Furthermore, the question of whether multiparameter DNA analysis of routinely processed tissue samples gives results comparable to those obtained with fresh tissue samples was addressed. To this end ten colorectal tumor samples were divided in two. One part was snap frozen and the other part was processed for paraffin embedding. Single cell suspensions were prepared from types both and stained with a panel of cytokeratin subtype-specific monoclonal 
antibodies. Cytokeratin detectability in the fresh and paraffin embedded tissues was examined and the S-phase fractions of the cytokeratin positive compartments of the two different protocols were compared.
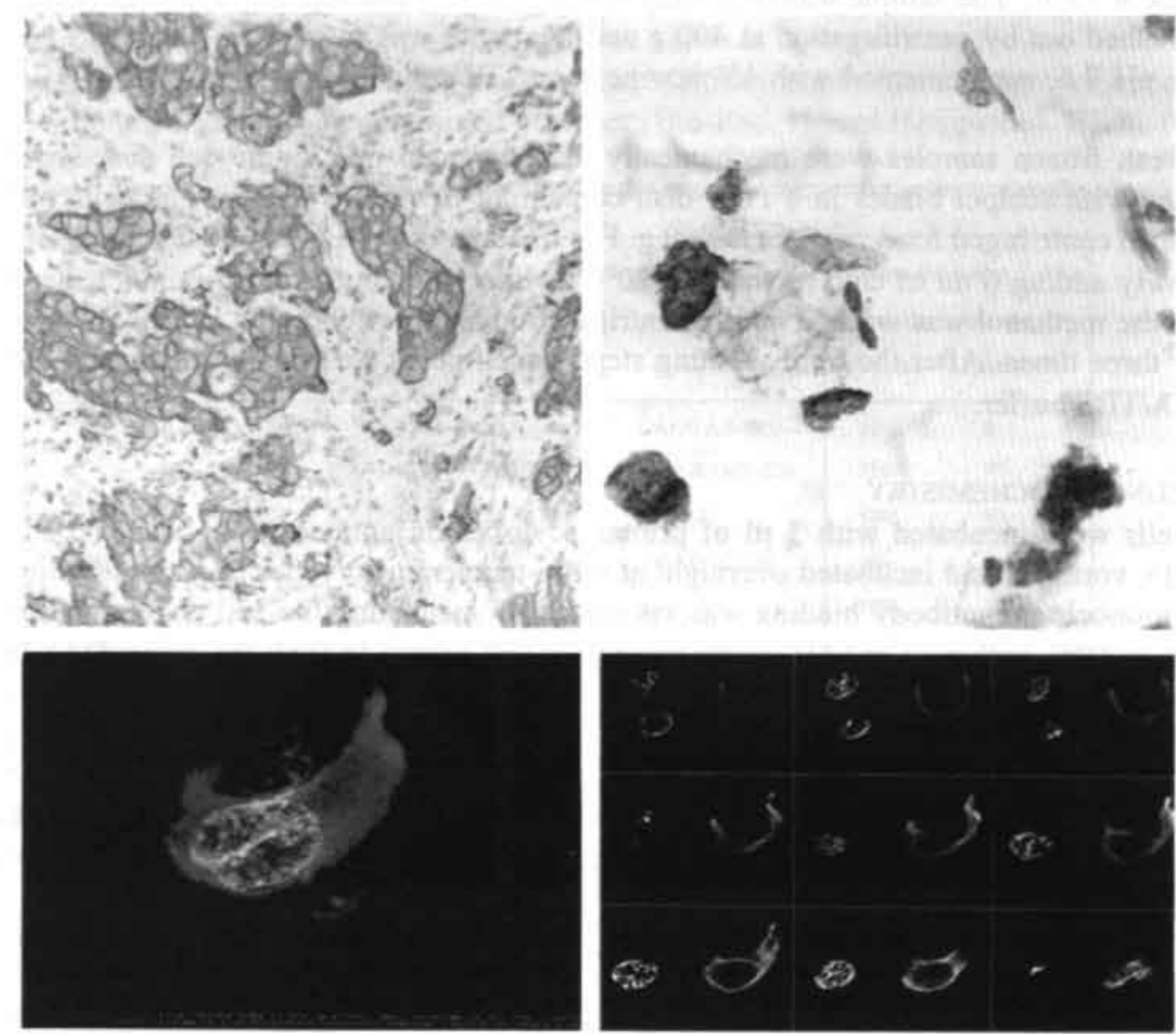

Figure 1

Immunoperoxidase staining of a colon adenocarcinoma paraffin embedded tissue section (A) and a single-cell suspension of the same adenocarcinoma (B) with the cytokeratin 19 antibody. Note the specific cytoplasmic immunoreaction in part of the cells in the cytocentrifuged preparations. Figure $\mathrm{C}$ shows the linear projection of nine $0.5 \mu \mathrm{m}$ serial confocal sections of a single cell suspension as prepared by flow cytometry, showing three cells stained with the anti-CK 19 (green) and propidium iodide (red). One of these cells retains his cytokeratin-skeleton. In figure D the consecutive confocal sections are shown (CK 19 right and PI left).

\section{Materials and methods}

\section{* TISSUE}

Fresh tissue samples were obtained from ten surgically resected colorectal carcinomas. Each tumor specimen was divided in two. One portion was snap frozen in liquid nitrogen and stored at $-70^{\circ} \mathrm{C}$, and another portion of the same tumor was immediately fixed in $10 \%$ buffered formalin for exactly $24 \mathrm{hr}$ and than routinely processed for paraffin embedding. 


\section{* SAMPLe pRePaRATION (TISSUE disSociation)}

From each of the paraffin blocks two $50 \mu \mathrm{m}$-thick sections were cut. They were deparaffinized in xylene and rehydrated in a series of decreasing concentrations of ethanol. The sections were digested in a solution of $1 \mathrm{mg}$ pepsin (Sigma, St.Louis, MO) in $1 \mathrm{ml} 0.1 \mathrm{~N} \mathrm{HCl}$ for 80 minutes at $37^{\circ} \mathrm{C}$. The sample was then filtered through a $50 \mu \mathrm{m}$ mesh nylon filter. The pepsin was washed out by centrifugation at $400 \mathrm{~g}$ and the pellet was resuspended in TRIS buffered saline, $\mathrm{pH} 7.6$, supplemented with $1 \%$ bovine serum albumine (BSA from Sigma; BSA/TBS buffer).

The fresh frozen samples were mechanically disaggregated into single cell suspensions by mincing with scalpel blades in a Petri dish containing BSA/TBS buffer. The cells obtained were then centrifuged for 8 minutes at $400 \mathrm{~g}$. For fixation, the cell pellet was then resuspended by slowly adding $6 \mathrm{ml}$ of cold methanol $\left(-20^{\circ} \mathrm{C}\right)$ while vortexing. After 5 minutes incubation on ice the methanol was washed out by centrifugation and the cell pellet rinsed in BSA/TBS buffer three times. After the third washing step the cell pellet was finally resuspended in 100 $\mu \mathrm{lBSA} / \mathrm{TBS}$ buffer.

\section{* IMMUNOCYTOCHEMISTRY}

The cells were incubated with $3 \mu \mathrm{l}$ of primary cytokeratin antibody (for characteristics see table 1), vortexed and incubated overnight at room temperature. After rinsing the samples in TBS, monoclonal antibody binding was visualized by incubating the cell pellet, resuspended in $100 \mu \mathrm{l}$ TBS, with $6 \mu \mathrm{l}$ of FITC-conjugated goat-anti-mouse Ig (Fab-fragment; DAKO A/S, Glostrup, Denmark; final dilution 1:15) for $1 \frac{1}{2} \mathrm{hr}$ at room temperature followed by two washing steps in TBS. The nuclei were finally counterstained with propidium iodide $(5 \mu \mathrm{g} / \mathrm{ml}$ PI, Sigma) in phosphate buffered saline (PBS, $\mathrm{pH} 7.4$ ) containing $0.1 \mathrm{mg} / \mathrm{ml} \mathrm{RNAse} \mathrm{(Serva,}$ Heidelberg, Germany) 15 minutes prior to flow cytometric analysis. Ten microliters of the cell suspension was examined by fluorescence microscopy to assess the efficiency of immunostaining and to determine that doublets comprised less than $5 \%$ of the cells to be studied. As a negative control for the specificity of cytokeratin staining, a cell suspension prepared from a normal lymph node, fixed for $24 \mathrm{hr}$ in $10 \%$ neutral buffered formalin and embedded in paraffin, was used. As a negative control for background staining, tumor cells were stained using the mouse monoclonal antiBrdU antibody (clone IIB5) ${ }^{15}$.

Parallel to the cytokeratin staining in suspension, consecutive $5 \mu \mathrm{m}$ thick sections of the same tumor tissue were stained with the same panel of cytokeratin antibodies using an indirect streptavidine-peroxidase labelings technique.

\section{* Flow CYTOMETRY}

All samples were analysed using a FACScan flow cytometer (Becton \& Dickinson,San Jose, CA, USA). Fluorochromes were excited with a single $488 \mathrm{~nm}$ Argon laser. Fluoresceine isothiocyanate fluorescence was detected through a $515-545 \mathrm{~nm}$ BP filter, and propidium iodide-fluorescence through a $572-588 \mathrm{~nm}$ BP filter. Electronic gating was used to exclude doublets and cellular debris. At least 20000 events were collected for each sample. Cell cycle analysis was performed with Cell fit software (Becton Dickinson). The S-phase fraction (SPF) was calculated from histograms of ungated cells and from cells gated for cytokeratin-positivity (fresh as well as formalin fixed and paraffin embedded samples of the same tumor). For 
diploid as well as for aneuploid tumors the polynomial model ${ }^{11}$ was used. SPF calculation was only performed when the cytokeratin-positive gate comprised at least 4000 events.

A tumor sample was designated negative for a specific cytokeratin subtype when the positive fraction was less than $5 \%$.

\section{* Confocal Scanning Laser Microscopy (CSLM)}

Cell suspensions were analysed using the Bio-Rad MRC600 confocal imaging system equiped with an air cooled Krypton/Argon mixed gas laser (Bio-Rad, Hemel Hempstead, UK).

Table 1 The monoclonal cytokeratin antibodies used in this study and immunohistochemical results of paraffin embedded coloncarcinomas $(n=10)$

\begin{tabular}{|c|c|c|c|c|c|c|}
\hline $\begin{array}{l}\text { Cytokeratin } \\
\text { subtype no. }\end{array}$ & Antibody & $\begin{array}{l}\text { dilu } \\
\text { on tissue } \\
\text { section }\end{array}$ & $\begin{array}{l}\text { n } \\
\text { on cell } \\
\text { suspension }\end{array}$ & Ref/Source & $\begin{array}{l}\text { positives } \\
\text { in paraff. } \\
\text { seetions }\end{array}$ & $\begin{array}{l}\text { eimens (\%) } \\
\text { in cell } \\
\text { suspension }\end{array}$ \\
\hline 7 & OVTL-12/30 & $1: 30$ & $1: 33$ & DAKO A/S (20) & 10 & 0 \\
\hline 8 & CAM 5.2 & $1: 75$ & $1: 33$ & Becton \& Dick.(22) & 100 & 90 \\
\hline 19 & RCK 108 & 1:30 & $1: 33$ & 17 & 100 & 80 \\
\hline 20 & IT-K, 20.8 & $1: 20$ & $1: 10$ & DAKO A/S (9) & 100 & 100 \\
\hline $5+8$ & RCK 102 & $1: 30$ & $1: 33$ & 17 & 100 & 30 \\
\hline $6+18$ & L.P 34 & 1:100 & 1:33 & DAKO A/S (18) & 90 & 70 \\
\hline
\end{tabular}

\section{Results}

The results of the immunocytochemical staining procedures applied to tissue sections of the formalin fixed, paraffin embedded colorectal carcinomas are summarized in Table 1. Each of the tumor samples examined displayed a wide variation in the number of cytokeratin-positive tumor cells (fig. 1, upper left). However, the specific reaction-pattern of the antibodies (as expected on basis of our earlier results in frozen tissue sections of colon cancer $^{10}$ and in paraffin sections of such malignancies ${ }^{20,21}$ ) were also observed in this series of cases. Carcinomas of the colon are in general negative for cytokeratin 7 antibodies, but positive for cytokeratin 20 . In only one case was an unexpected positivity for cytokeratin 7 observed. The other, more broadly cross-reacting antibodies are positive in colon cancers. The results of the immunocytochemical staining reactions in the cell suspensions, derived from formalin fixed and paraffin embedded colorectal carcinomas are summarized in Table 1 and are also illustrated in Figure 1. Despite enzymatic digestion, many epithelial cells were found to retain the cytokeratins as evidenced by positive immunoreactivity of the majority of the cells after application of most of the antibodies. The staining results in tissue sections with the six different antibodies correlated well with the staining results of the cell suspensions prepared for flow cytometry. A discrepancy was noted in one case, in which positive staining for cytokeratin 7 was observed in the tissue section, but was not found in the cell suspension. Furthermore, the immunoreactivity of RCK102 was frequently negative in the cell suspension, compared with the tissue section of the same tumor. 
The double-stained cell suspension, when analyzed by bivariate flow cytometry, showed a coëfficient of variation (CV) of the $\mathrm{G}_{0} / \mathrm{G}_{1}$-peak ranging from 2.3 to $3.9 \%$ for the fresh samples and from 1.7 to $3.6 \%$ for the formalin fixed, paraffin embedded part of the tumor (table 2). In general, the cytokeratin-positive fraction was greater in cell suspensions derived from fresh tissue than in the corresponding paraffin sample. DNA-aneuploidy was found in 7 out of the 10 colorectal carcinomas. Gating on cytokeratin-positive cells (Figure 2) allowed a more accurate determination of near-diploid $\mathrm{G}_{0} / \mathrm{G}_{1}$-cells in two cases by exclusion of the inflammatory and stromal cells (fig. 3). SPF increased after gating on cytokeratin-positive cells, both in paraffin embedded and in fresh tissue samples. The difference in SPF between ungated and gated cell populations was more pronounced with paraffin embedded tissue than with fresh tissue. This increase in SPF after gating was observed (see table 2) in all cytokeratin subtypes.

Figure 2

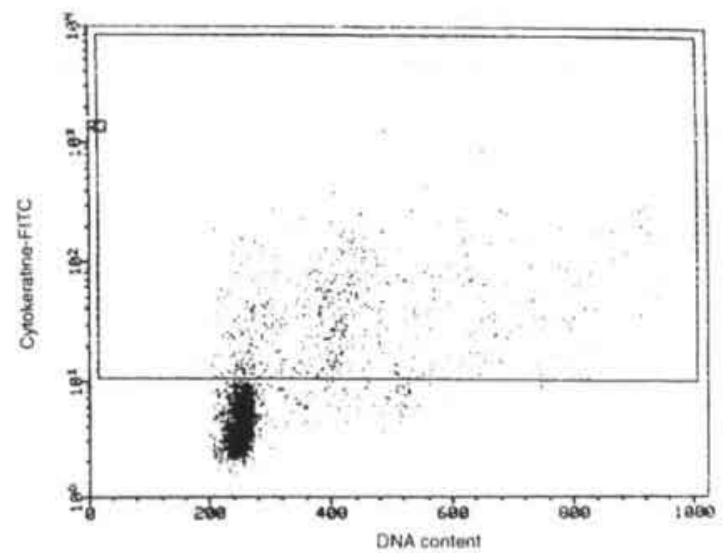

Dotplot of the DNA-content ( $x$-axis) vs. CK 19 immunofluorescence ( $y$-axis) of a DNA aneuploid colorectal tumor. The box indicates the gate for CK-immunoreactivity. This gated cells were used for cell cycle analysis.
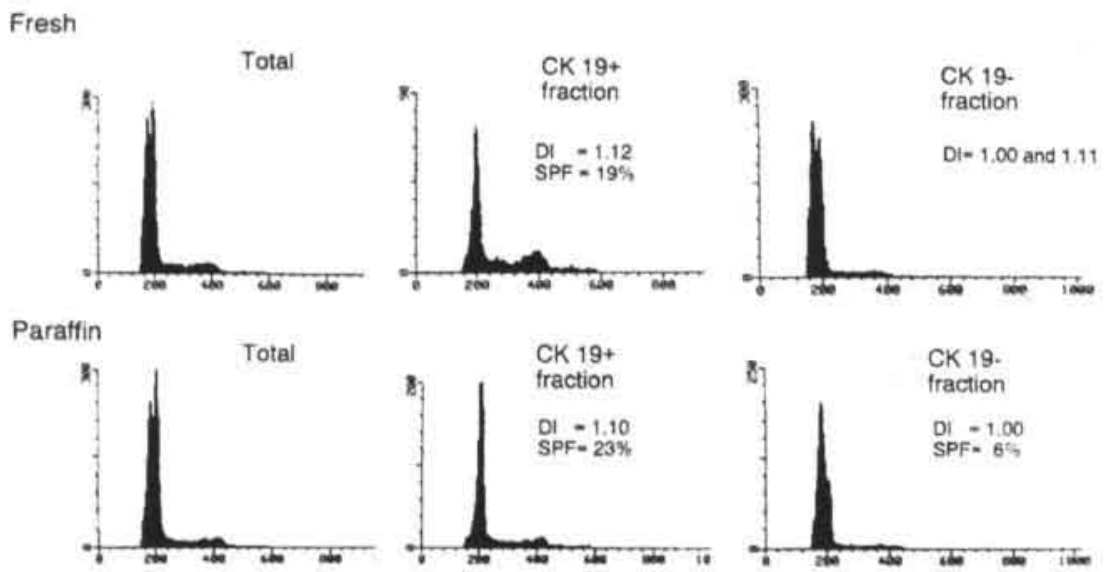

Figure 3

An example of a near-diploid colon tumor. Histograms in the top and bottom panel represent fresh and paraffin embedded tumor samples, respectively. The left, middle and right panel show the DNA-histograms of total, CK 19-positive and CK 19-negative cells, respectively. Note the enrichment of the DNA aneuploid population in the CK 19-positive fraction. 
The correlation in the DNA-index of the paraffin embedded tumor samples and the fresh samples is shown in figure 4 . The correlation coëfficient as determined by regression analysis was $0.99(\mathrm{p}<0.00001)$.

Table 2 Overall cell kinetic results of the colorectal carcinoma $(\mathrm{n}=10)$ cell suspensions in ungated and cytokeratin gated fractions

\begin{tabular}{|c|c|c|c|c|c|c|c|}
\hline Antibody $\quad \Rightarrow$ & UG & OVTL12 & CAM5.2 & RCK108 & IT-K.20.8 & RCKI02 & LP34 \\
\hline Cytokeratin no. $\Rightarrow$ & & CK 7 & CK 8 & CK 19 & CK 20 & CK $5+8$ & CK6+18 \\
\hline Mean \%pos. fraction fresh & - & 8 & 35 & 45 & 46 & 43 & 30 \\
\hline Mean \%pos. fraction paraffin & - & 3 & 23 & 24 & 25 & 6 & 12 \\
\hline Mean $\mathrm{CV} \mathrm{G}_{0} / \mathrm{G}_{1-\text {-peak fresh }}$ & 3.9 & - & 2.3 & 2.7 & 2.3 & 3.1 & 3.1 \\
\hline Mean $C V G_{0} / G_{1}$-peak paraffin & 3.6 & - & 2.5 & 3.2 & 2.9 & 2.6 & 1.7 \\
\hline Mean SPF fresh $(\%)$ & $14(4)$ & - & $21(6)$ & $22(6)$ & $20(5)$ & $19(3)$ & $20(4)$ \\
\hline Mean SPF paraffin (\%) & $16(11)$ & - & $23(6)$ & $26(7)^{\circ}$ & $30(6)^{*}$ & $26(5)$ & $27(5)$ \\
\hline
\end{tabular}

Between brackets are the standard deviation. SPF $=$ S-phase fraction; UG=ungated, no label; $\mathrm{CV}=$ coe̊fficient of variation. * indicates a significant difference between the SPF of the cell suspension derived from the fresh tissue and those for the paraffin embedded tumor samples (confidence interval for the difference between means of two groups of paired observations not greater than zero)

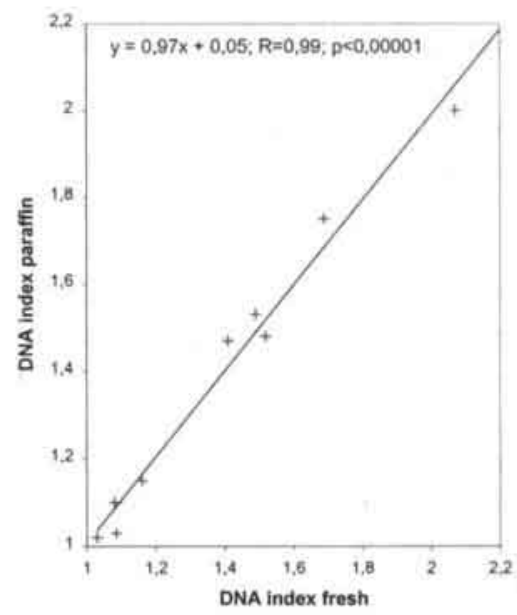

Figure 4

Scatter diagram with regression line demonstrating the relationship of the DNA-index obtained from fresh frozen tissues as compared to the DNA index of formalin fixed, paraffin embedded tumor samples $(y=0.97 x+0.05: r=0.99 ; p<0.00001)$. 


\section{Discussion}

Admixture of normal and malignant cells is a serious problem when cell kinetic parameters of malignancies are evaluated by flow cytometry, in particular for DNA diploid tumors. In such cases, flow cytometric analysis may underestimate the S-phase fraction (SPF) ${ }^{7}$. A dilutional effect resulting from non-neoplastic cells (stromal and inflammatory cells) may lower tumor SPF calculations artifactually.

Until recently bivariate flow cytometric analysis of tumors was restricted to fresh tissue samples, allowing only prospective studies. Here we describe a method that makes it possible to use formalin fixed and paraffin embedded tissue samples for multiparameter flow cytometric analysis on the basis of cytokeratin and DNA staining reactions.

Several enzymatic digestion-protocols were tested (pepsin ${ }^{8}$, trypsin ${ }^{15}$ and pronase); they showed that the recovery of single cells and immunoreactivity (assesed by fluorescencemicroscopy) was greatest with pepsin-digestion. Also, different incubation-times of pepsindigestion were investigated. An incubation-time longer than 90 minutes resulted in a decrease of immunoreactivity for the different cytokeratins (data not shown).

The application of monoclonal antibodies against different types of cytokeratins showed comparable results with respect to immunoreactivity as in earlier investigations ${ }^{20,13}$ on colorectal adenocarcinomas. For example, cytokeratin 7 was shown to be absent in colorectal adenocarcinomas $^{20}$ and cytokeratin 20 was found to be ubiquitously positive in such malignancies. ${ }^{9}$. In general, in this study a good agreement was found between the immunoreactivity in the section compared with the reaction patterns found in the cell suspension. However, the immunoreactivity of RCK102 was frequently lost in the tumor cell suspensions compared with the immunochemical staining of a section of the same paraffin embedded tumor. An explanation could be that its epitope is more susceptible to enzymatic digestion. Another remarkable finding was that one tumor sample showed positive immunohistochemical reactivity for cytokeratin 7 . This finding was also observed by Wauters et $\mathrm{al}^{21}$ who also described immunoreactivity for cytokeratin 7 in a few colorectal adenocarcinomas. All of the ten colorectal adenocarcinomas investigated showed positive immunoreactivity for cytokeratin 20 in the single cell suspensions derived from fresh as well as from paraffin embedded tissues. This is in agreement with earlier findings of Moll et al'.

The different cytokeratin-subtypes tested are preserved after enzymatic digestion. The observation that the cytokeratin-positive fraction derived from paraffin embedded tissue is relatively smaller than the cytokeratin reactive fraction of the fresh tissue sample could be explained by the finding of Crissman et al. ${ }^{2}$ that enzymatic treatment appears to release preferentially diploid stromal and inflammatory cells. It is not likely that a part of the tumorcells in the paraffin embedded tissue will have lost all of the cytoplasm by enzymatical digestion and will not therefore show immunoreactivity with the different cytokeratinmonoclonal antibodies, because we could not detect any aneuploid, cytokeratin negative cells (see fig. 2).

The SPF of the gated cytokeratin-positive cell population in fresh as well as formalin fixed, paraffin embedded tissue-samples is increased (for all CK's) compared with the SPF of the ungated cell population. This is explained by the presence of DNA diploid tumor cells. Another possibility that cannot be excluded is a difference in cell population introduced by the 
cell isolation-method (mechanically vs. enzymatically) ${ }^{16}$. Surprisingly, in this series of colorectal carcinomas, the mean SPF of the single cell suspension derived from the paraffin embedded part of the tumor, both in gated as in ungated cells, was consistently higher compared with the single cell suspension derived from the fresh, frozen part of the tumor. This could mean a relatively better preservation of the proliferating cell compartment than of the resting cell compartment in formalin fixed tissue ${ }^{6}$ or it could be due to the effects of sectioning and debris for which no correction was applied ${ }^{16}$. A consequence of this is the development of separate standards for fresh frozen and for paraffin embedded preparations.

The present study shows that dual parameter flow cytometric DNA analysis on formalin fixed and paraffin embedded tissue samples of ten colorectal carcinomas, compared with the results of the analysis on fresh tissue samples, gives an excellent correlation between DNA-index of the ten formalin-fixed, paraffin embedded and fresh, frozen colorectal carcinoma-samples. These finding were in concordance with earlier studies of Edmin et $\mathrm{al}^{4}$ and Roos et $\mathrm{al}^{12}$.

With this method, it may now be possible to evaluate cell kinetic parameters in routinely processed histological material. However, SPF-data obtained with fresh material must be kept separate from those obtained with paraffin embedded material, as we expected that for both protocols distinct cut-of points (for survival or disease course) must be defined ${ }^{16}$.

\section{Acknowledgement}

The authors thank the members of the department of hematology (head: dr. J. v. Wersch) for the use of and the technical assistance with the flow cytometer 


\section{References}

1. Atkin N, Ray R. Prognostig significance of model DNA value and other factors in malignant tumours, based on 1465 cases. Br J Cancer 1979; 40: 210-221

2. Crissman JD Zarbo RJ, Niebylski CD, Corbett T, Weaver D. Flow cytometric DNA analysis of colon adenocarcinomas; a comparative study of preparatory techniques. Mod Pathol 1988; 1: 198-204

3. Crissman JD, Zarbo RJ, Ma CK, Visscher DW. Histopathological parameters and DNA analysis in colorectal adenocarcinomas. Pathology Annual 1989; 24: 103-147

4. Edmin S, Stenling R, Roos G.Prognostic value of DNA content in colorectal carcinoma; a flow cytometric study with some methodological aspects. Cancer 1987; 60: 1282-1287

5. Feitz WFJ, Beck HLM, Smeets AWGB, Debruyne FMJ, Vooijs GP, Herman CJ. Tissue specific markers in flow cytometry of urological cancers: cytokeratins in bladder carcinoma. Int J Cancer 1985; 36: 349-356

6. Frei JV, Martinez VJ. DNA flow cytometry of fresh and paraffin-embedded tissue using cytokeratin staining. Mod Pathol 1993; 6: 599-605

7. Hall PA, Levison DA, Wright N. Assesment of cell proliferation in clinical practice. Londen: Springer Verlag 1992

8. Hedley DW, Friedlander ML, Taylor IW, Rugg CA, Musgrove EA. Method for analysis of cellular DNA content of paraffin-embedded pathological material using flow cytometry. J Histochem Cytochem 1983; 31: 1333-1335

9. Moll R, LIIwe A, Laufer J, Franke WW. Cytokeratin 20 in human carcinomas. Am J Pathol; 1992: 140: $427-447$

10. Ramaekers FCS, Van Niekerk C, Poels L, Schaafsma E, Huijsmans A, Robben H, Schaart G, Vooijs GP. Use of monoclonal antibodies to keratin 7 in the differential diagnosis of adenocarcinomas. Am J Pathol 1990; 136: 641-655

11. Riley RS, Mahin EJ, Ross W. Clinical applications of flow cytometry. Igaku-Shoin medical publishers inc. New York, 1993, pp 296-302

12. Roos G, Stenling R, Ljungberg B. DNA content in renal cell carcinoma; a comparison between flow and static cytometric methods. Scand J Urol Nephrol 1986; 20: 295-300

13. Schasfsma HE, Ramaekers FCS. Cytokeratin subtyping in normal and neoplastic epithelium: basic principles and diagnostic applications. Pathology Annual 1994; 29: 21-62

14. Schutte B, Reynders MMJ, Wiggers T, Arends JW, Volovics L, Bosman FT, Blijham GH. The prognosic significance of DNA content and proliferative activity in large bowel carcinoma. Cancer Res 1987; 47: 5494-5496

15. Schutte B, Reynders MMJ, Bosman FT, Blijham GH. Studies with antibromodeoxyuridine antibodies. II Simultaneous detection of antigen expression and DNA synthesis by in vivo labeling of mouse intestinal mucosa. J Histochem Cytochem 1987; 35: 371-374

16. Shankey VT, Rabinovitch PS, Bagwell B, Bauer KD, Duque RE, Hedley DW, Mayall BH, Wheeles L. Guidelines for implementation of clinical DNA cytometry. Cytometry 1993; 14:472-477

17. Smedts F, Ramaekers FCS, Troyanovsky S, Pruszezynski M, Link M, Lane B, Leigh I, Schijf C, Vooijs P. Keratin expression in cervical cancer. Am J Pathol 1992; 141: 497-511

18. Smedts F, Ramaekers FCS, Troyanovsky S, Pruszczynski M, Robben H, Lane B, Leigh I, Plantema F, Vooijs P. Basal-cell keratins in cervical reserve cells and a comparison to their expression in cervical intraepithelial neoplasia. Am J Pathol 1992; 140: 601-612

19. Ten Velde G, Schutte B, Vermeulen A, Volovics A, Reynders MMJ, Blijham GH. Flow cytometric analysis of DNA ploidy level in paraffin-embedded tissue of non-small cell lung cancer. Eur J Clin Oncol 1988; 24: 455-460

20. Van Niekerk CC, Jap PHK, Ramaekers FCS, Van de Molengraft F, Poels LG. Immunohistochemical demonstration of keratin 7 in routinely fixed paraffin embedded human tissues. J Pathol 1991; 165: 145-152

21. Wauters CCAP, Smedts F, Gerrits LGM, Bosman FT, Ramaekers FCS. Keratins 7 and 20 as diagnostic markers of carcinomas metastatic to the ovary. Human Pathology $1995 ; 26: 852-855$

22. Zarbo RJ, Visscher DW, Crissman JD. Two-color multiparametric method for flow cytometric DNA analysis of carcinomas using staining for cytokeratin and leucocyte common antigen. Anal Quant Cytol Histol 1989; 11: 391-402 


\section{Multi-parameter flow cytometric analysis with detection of the Ki67-Ag in paraffin embedded mammary carcinomas}

M.P.G. LEERS ${ }^{1}$, P.H.M.H. THEUNISSEN ${ }^{1}$, F.C.S RAMAEKER ${ }^{2}$, B. SCHUTTE ${ }^{2}$

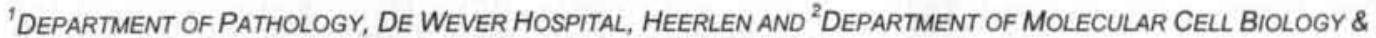
GENETICS, UNIVERSITY OF LIMBURG, MAASTRICHT, THE NETHERLANDS

CYTOMETRY 1997; 27: 283-289 


\begin{abstract}
In the present study we describe a novel multiparameter flow cytometric (FCM) assay to estimate the fraction of cycling cells in epithelial tumors derived from fresh frozen as well as archival material. To this end, MCF-7 cells as well as a series of breast carcinomas ( $n=10$; fresh frozen as well as formalin fixed and paraffin embedded) were stained using a panel of different antibodies directed against the Ki67-Ag (DAKO/PC, MIB-1, Ki-S5 and poly-Ki67) for a three parameter cytokeratin/Ki67-Ag/DNA FCM analysis.

Whereas all Ki67-Ag antibodies work equally well in the methanol fixed cell line, MIB-1 and $\mathrm{Ki}-\mathrm{S} 5$ epitopes are retained in cell suspensions mechanically derived from fresh frozen tissue. Only antibody Ki-S5 shows specific nucleolar staining patterns in cell suspensions prepared by trypsin digestion of formalin fixed, paraffin embedded tissue sections. A good correlation was found between the fractions of $\mathrm{Ki67-Ag-positive} \mathrm{epithelial} \mathrm{cells} \mathrm{measured} \mathrm{in} \mathrm{cell}$ suspensions derived from fresh frozen and the corresponding formalin fixed and paraffin embedded tumor samples. Furthermore the fraction of Ki67-Ag-positive epithelial cells as determined by three parameter FCM, correlated very well with the Ki67-Ag-labeling index in paraffin embedded tissue sections.
\end{abstract}

\title{
Introduction
}

Estimation of cell proliferation parameters in human breast carcinomas may provide useful information concerning tumor prognosis and aid in diagnosis ${ }^{1,9}$. Today one of the most frequently used methods to determine the growth fraction of a tumor is the immunohistochemical detection of proliferation-associated antigens, such as the Ki67-Ag. Detailed cell cycle analysis revealed that this high molecular weight protein represents a nuclear constituent that is exclusively expressed in proliferating cells, i.e. in $\mathrm{G}_{1^{-}}, \mathrm{S}-, \mathrm{G}_{2^{-}}$and $\mathrm{M}$-fase, but not in $\mathrm{G}_{0}{ }^{6}$. Barnard et al have found that the Ki67-score provides an objective indicator of biological behaviour of breast carcinomas and may thus be of clinical significance.

A major limitation of the first generation antibodies to the Ki67-Ag was that they could only be applied to fresh (frozen) tissue, since the epitope is rapidly destroyed by formalin fixation ${ }^{5}$. Second generation $\mathrm{Ki} 67$-antibodies, such as polyclonal antiserum $\mathrm{Ki} 67^{10}, \mathrm{MIB1}^{7}$ and $\mathrm{Ki}-\mathrm{S} 5^{11}$, raised against peptides from recombinant fragments of the $\mathrm{Ki} 67-\mathrm{Ag}$ gene, are reactive in routinely processed (formalin fixed, paraffin embedded) tissue sections after antigen retrieval by microwave irradiation.

Combined measurement of the Ki67-Ag and DNA content using flow cytometry offers the possibility to study the expression of this marker in relation to the cell cycle phase and ploidy level. However, admixture of non-neoplastic (stromal and inflammatory) cells in the cell suspensions prepared for FCM, lead to an underestimation of the proliferative fractions of the tumor. The application of cytokeratin immunostaining in FCM has recently been shown to result in more accurate calculations of cell cycle compartments ${ }^{4,13,14,18}$. Taking this technology one step further involves a combined measurement of the Ki67-Ag and an epithelial marker to analyse only the epithelial fraction of a tumor. With this technique, the cells of interest can be selected. Recently a trivariate FCM staining technique was described 
by Schutte et al. ${ }^{17}$ in which cytokeratin staining was combined with bivariate Ki67-Ag/DNA analysis in fresh frozen tissue.

The aim of the present study was to investigate whether or not the Ki67- $\mathrm{Ag}$ can be accurately analysed in cell suspensions derived from paraffin embedded tissue. For this purpose we examined a series of breast carcinomas (fresh frozen as well as formalin fixed, paraffin embedded tumor parts) with a panel of reagents against the Ki67-Ag in a trivariate FCM analysis. A comparison was made between the results obtained with fresh frozen and with paraffin embedded samples. Furthermore, the question was adressed whether or not trivariate cytokeratin/Ki67-Ag/DNA FCM analysis of the suspensions results in Ki67 labeling indices comparable to those obtained in tissue sections.

A

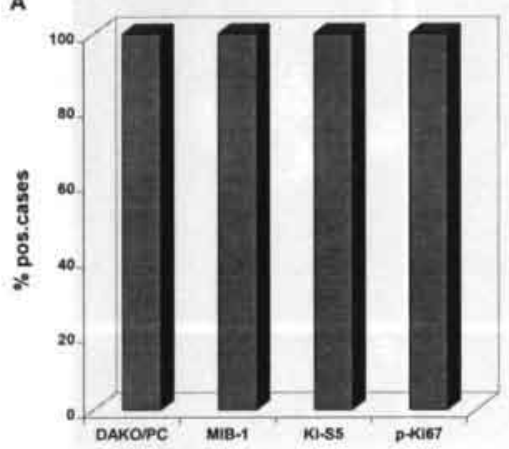

c

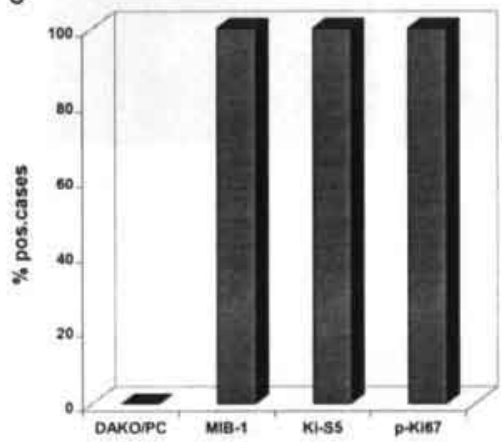

B

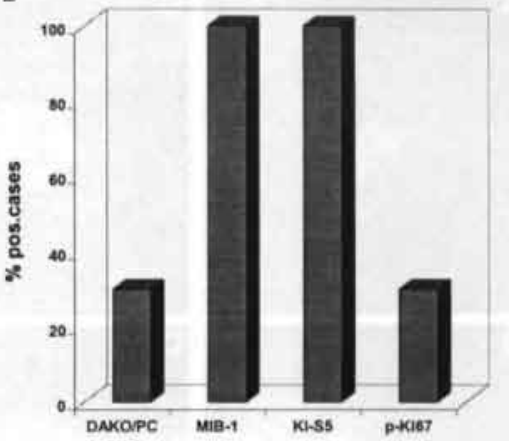

D

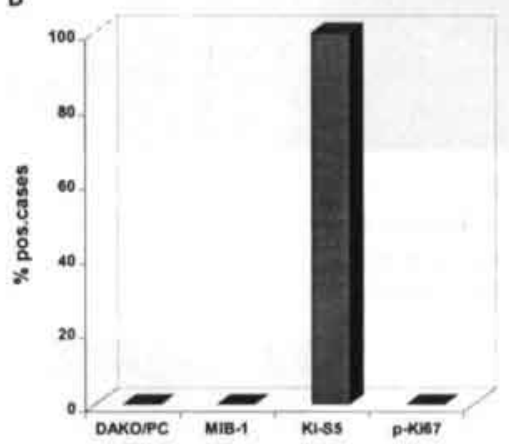

Figure 1

Antibody

The number of tumor cases positive for the four different Ki67-Ag antibodies, in either tissue sections from fresh frozen (A) and formalin fixed, paraffin embedded breast cancer (C) or in cell suspensions prepared from these fresh frozen (B) and paraffin embedded samples (D). Only the Ki-S5 monoclonal antibody showed excellent immunoreactivity in cell suspensions prepared from paraffin embedded blocks. (A total of 10 tumors were tested; p-Ki67: polyclonal antiserum to Ki67-Ag (DAKO A/S)) 


\section{Materials and methods}

* Cell LINE

The human breast cancer cell line MCF-7, purchased from the ATCC (Rockville, MD) were cultured in Eagle's minimal essential medium (Gibco, Paisley, Scotland), supplemented with $1 \%$ non essential amino acid solution (Gibco), $1 \%$ glutamine (Serva, Heidelberg, Germany; no. 22942), 1\% HEPES (Gibco), 10\% heat-inactivated newborn calf serum (Gibco, 021$6010 \mathrm{M}$ ) and $0.1 \%$ gentamycin (AUV, Cuyk, The Netherlands). Cells were grown in a humified incubator $\left(5 \% \mathrm{CO}_{2}, 95 \%\right.$ air $)$ at $37^{\circ} \mathrm{C}$. Cells were harvested during exponential growth by trypsinization.
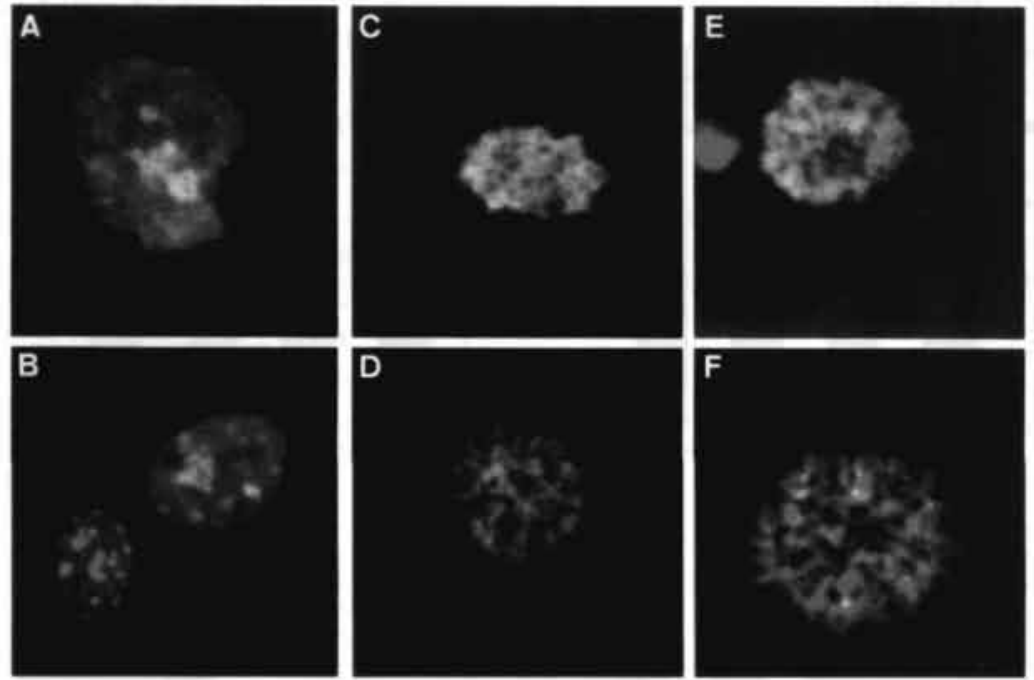

Figure 2

Linear projections of confocal images of cells after staining with Ki-S5 (green) and DNA (PI: red) in a single-cell suspension prepared from a paraffin embedded mammary carcinoma. A and B represent cells in interphase, while $\mathrm{C}, \mathrm{D}, \mathrm{E}$ and $\mathrm{F}$ represent mitotic cells

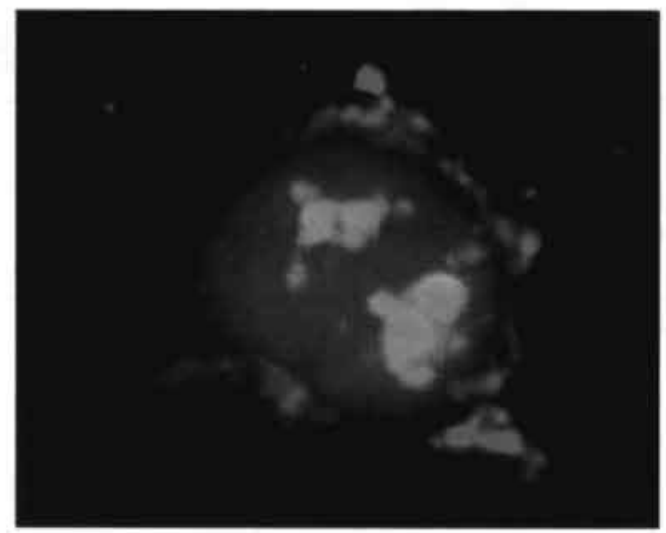

Figure 3 Linear projection of confocal sections of a formalin fixed, paraffin embedded single cell prepared for three-parameter FCM, showing staining for cytokeratin (red), Ki67-Ag (green) and DNA (DAPI; blue). 


\section{* TISSUE SPECIMENS}

Fresh tissue specimens of 10 breast carcinomas obtained immediately after surgical resection were divided in two. One portion was snap frozen in liquid nitrogen and stored at $-70^{\circ} \mathrm{C}$, and another portion of the same tumor was immediately fixed in $10 \%$ buffered formalin for exactly $24 \mathrm{hrs}$ and routinely processed for paraffin embedding.

From each of the paraffin blocks two $50 \mu \mathrm{m}$ thick sections were cut. These were deparaffinized in xylene and rehydrated in a descending ethanol series. The sections were digested in a solution of $1 \mathrm{mg}$ trypsin (type II from porcine pancreas; Sigma, St. Louis, MO) and $1 \mathrm{mg} \mathrm{CaCl} 2$ in $1 \mathrm{ml}$ phosphate buffered saline (PBS) for 70 minutes at $37^{\circ} \mathrm{C}$. The sample was then filtered through a $50 \mu \mathrm{m}$ mesh nylon filter. The trypsin was washed out by centrifugation at $400 \mathrm{x}$ g, the pellet was resuspended in PBS, and supplemented with $1 \%$ bovine serum albumine (BSA; Sigma).

After thawing in PBS, the fresh frozen tissue blocks were mechanically disaggregated by mincing with scalpel blades. Before fixation the cell suspension was filtered through a $50 \mu \mathrm{m}$ nylon mesh. To approximately $10^{6}$ single cells in $100 \mu \mathrm{l} \mathrm{PBS,} 500 \mu \mathrm{l}$ cold lysis buffer ${ }^{12}$ was added, containing PBS (pH 7.4), $0.5 \%$ Triton X-100, $10 \mathrm{mg} / \mathrm{ml}$ BSA (Sigma) and $0.01 \mu \mathrm{g} / \mathrm{ml}$ EDTA. After gentle mixing, the suspension was kept on ice for 15 minutes. The cells were fixed by adding $3 \mathrm{ml}$ of cold absolute methanol $\left(-20^{\circ} \mathrm{C}\right)$. After 10 minutes incubation at room temperature the methanol was removed by centrifugation and the cell pellet was rinsed in PBS supplemented with $1 \mathrm{mg} / \mathrm{ml}$ BSA (PBS/BSA).

\section{* IMMUNOCYTOCHEMISTRY}

A double-label indirect immunofluorescence technique, combining a polyclonal and a monoclonal antibody, was used with fluorescein isothiocyanate (FITC)- and r-phycoerythrin (RPE)-conjugated secondary antibody reagents. The characteristics and source of the antibodies used in this study are summarized in table 1. The single cell suspension was aliquoted into $100 \mu \mathrm{l}$ samples. To each sample both primary antibodies (a cytokeratin and a Ki67- $\mathrm{Ag}$ marker) were added simultaneously. After overnight incubation at $4^{\circ} \mathrm{C}$ the samples were rinsed twice in PBS by centrifugation at $400 \mathrm{x}$ g. Antibody binding was visualized by incubating the cell pellet simultaneously with both secondary antibodies, i.e. goat-anti-rabbit Ig-RPE (Boehringer Mannheim, Almere, NL; diluted 1:20) and goat-anti-mouse Ig-FITC (DAKO A/S; diluted 1:10). After incubation for $1 \frac{1}{2} \mathrm{hr}$ at room temperature, the samples were again rinsed twice in PBS and finally counterstained with propidium iodide (PI; $1.0 \mu \mathrm{g} / \mathrm{ml}$; Sigma) in PBS containing $0.1 \mathrm{mg} / \mathrm{ml}$ RNAse (Serva, Heidelberg, Germany). The samples were allowed to stand for 15 minutes on ice in the dark before flow cytometric analysis. As a negative control for background staining, tumor cells were stained with the mouse monoclonal anti-BrdU antibody IIB5 ${ }^{16}$. For confocal scanning laser microscopic analysis, the cell pellet was not counterstained with propidium iodide, but resuspended in $90 \%$ glycerol with $10 \% 0.2$ M TRIS- $\mathrm{HCl}(\mathrm{pH}=8.0)$ containing $0.5 \mu \mathrm{g} / \mathrm{ml} 4^{\prime} 6$ 'diamidino-2 phenylindole (DAPI; Sigma) for DNA counterstaining, and 2\% 1,4-diaza bicyclo-(2,2)-octane (DABCO; Merck, Darmstadt/Germany) as an antifading agent.

In parallel to the immunostaining reactions performed in suspension, consecutive $5 \mu \mathrm{m}$ thick sections of the fresh frozen as well as the paraffin embedded tumor tissues were immunostained with the four different primary Ki67Ag-antibodies, using a streptavidinebiotin-peroxidase complex method and a solution with 3,3'-diaminobenzidine (DAB) as a 
substrate in a $0.002 \% \mathrm{H}_{2} \mathrm{O}_{2}$-solution (Sigma Chemical Co., St. Louis, MO) to visualize the immune complexes. Before immunostaining paraffin sections with the primary antibodies, the $\mathrm{Ki67-Ag}$ epitope was unmasked by boiling the tissue sections in a $0.1 \mathrm{M}$ citrate buffer $(\mathrm{pH}=6.0)$ for 10 minutes in a microwave. After immunostaining, the sections were counterstained with Harris' hematoxylin, dehydrated, cleared in xylene and finally embedded in Entellan.

Table 1 Antibody characteristics

\begin{tabular}{|c|c|c|c|c|c|}
\hline Antigen & Clone/Cat.No. ${ }^{*}$ & poly'mono & Dilution & Ref & Source \\
\hline \multirow[t]{2}{*}{ cytokeratins } & Lu-5 & $\operatorname{moAb}$ & $1: 50$ & 15 & BioGenex, San Ramon, USA \\
\hline & PU071-UP* & poAb & $1: 33$ & 3 & BioGenex, San Ramon, USA \\
\hline \multirow[t]{4}{*}{ Ki67-Ag } & DAKO-PC & moAb & $1: 10$ & 5 & DAKO A/S, Glostrup, Denmark \\
\hline & MIB-1 & moAb & $1: 12$ & 7 & Immunotech, Marseille, France \\
\hline & Ki-Ss & $\operatorname{moAb}$ & $1: 15$ & 11 & Bochringer Mannheim, Almere, NL. \\
\hline & A- $-0047^{\circ}$ & poAb & $1: 100$ & 10 & DAKO A/S, Glostrup, Denmark \\
\hline BrdU (control) & IIB5 & moAb & $1: 33$ & 15 & Euro-Diagnostica BV, Apeldoom, NL \\
\hline
\end{tabular}

\section{* ESTIMATION OF THE KI67-Ag LABELING INDEX IN TISSUE SECTIONS}

Diffuse or dot-like nuclear reactivity was considered specific for Ki67-Ag. Because proliferating cells are heterogeneously distributed throughout the section, positive cells were quantified by counting not less than 500 tumor cells in three or four different fields at $400 \mathrm{x}$ magnification.

\section{* FLOW CYTOMETRY}

All samples were analysed using a FACScan flow cytometer (Becton Dickinson,San Jose, CA, USA). Fluorochromes were excited with a single $488 \mathrm{~nm}$ argon laser. FITC fluorescence was detected through a 515-545 nm BP filter, RPE fluorescence through a 572-588 nm BP filter and PI-fluorescence through a $600 \mathrm{~nm}$ LP filter. Pulse-processing was used to exclude doublets and cellular debris. At least 20,000 events were collected for each sample. FITC-and RPE-signals were recorded as logarithmic amplified data, while the PI-signals were recorded as linear amplified data. The following settings were used: $448 \mathrm{~V}, 405 \mathrm{~V}$ and $437 \mathrm{~V}$ on photomultiplier tubes for FL1 (FITC), FL2 (PE) and FL3 (PI), respectiveley. Compensation for (FL1-\%FL2), (FL2-\%FL1), (FL2-\%FL3) and (FL3-\%FL2) was $1.1 \%, 38.5 \%, 41.8 \%$ and $8.3 \%$, respectively. Data analysis was performed using Lysis II software (Becton Dickinson). The number of Ki67-Ag positive cells (designated as $\mathrm{Ki67-Ag}$ positive cell fraction) was determined by an arbitrary threshold setting, allowing not more than $5 \%$ of positive cells in the negative control, and expressed without subtraction of this unspecifically stained fraction.

\section{* Confocal ScAnNing Laser Microscopy}

Cells stained in suspension were allowed to attach to glass slides, covered with a coverslip and sealed with nail polish. These slides were analysed using the Bio-Rad MRC600 confocal imaging system equipped with an air cooled Krypton/Argon mixed gas laser (Bio-Rad, Hemel Hempstead, UK). 


\section{Results}

Several enzymatic digestion protocols to prepare a single cell suspension from paraffin embedded tissue blocks were tested (pepsin, trypsin and pronase; data not published). The recovery of single cells was greatest with pepsin digestion; however, all the antibodies against the Ki67-Ag showed no immunoreactivity in these suspensions. Surprisingly, after trypsin digestion, the Ki-S5 MoAb showed a strong cell cycle specific immunoreactivity. When 50 $\mu \mathrm{m}$ thick deparaffinized and rehydrated tumor tissue sections were digested by trypsin for 70 minutes $\left(37^{\circ} \mathrm{C}\right)$, a sufficient number of single nuclei could be obtained to perform multiparameter FCM-analyses. These nuclei had retained enough cytoskeletal remnants to allow immunocytochemical detection of cytokeratin filaments.
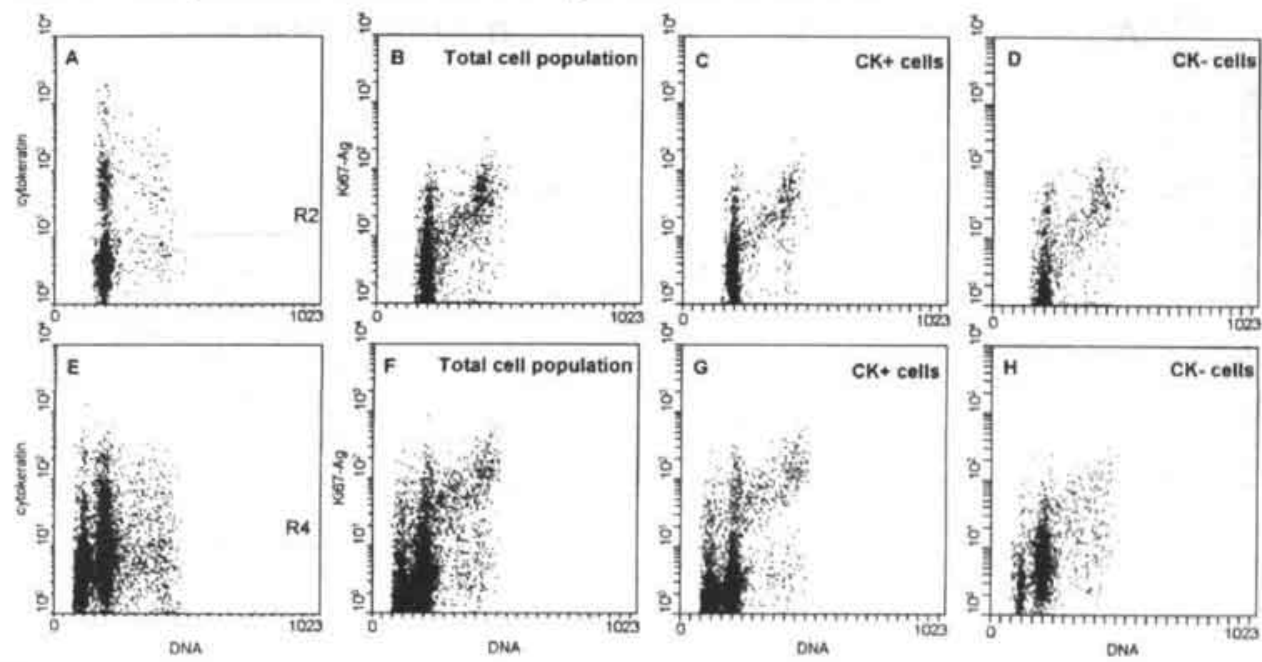

Figure 4

Examples of trivariate cytokeratin/Ki67-Ag/DNA FCM analysis of a diploid (A-D) and an aneuploid (E-G) mammary carcinoma. A and $\mathrm{E}$ show a dotplot of DNA content ( $\mathrm{x}$-axis) vs. cytokeratin content ( $\mathrm{y}$-axis). The solid lines denote the threshold for positivity based on negative controls. B and $\mathrm{F}$ shows the dotplots of the negative control for Ki67. C and G depict the dotplots of DNA content ( $x$-axis) vs. Ki67-Ag immunoreactivity ( $y$-axis) of the ungated data, while in D and $\mathrm{H}$ dotplots of DNA vs. Ki67 are shown after gating for cytokeratin positivity. The fraction of $\mathrm{Ki67}-\mathrm{Ag}$ positive cells in the diploid tumor was increased after gating from $9 \%$ (C) to $20 \%$ (D) and for the aneuploid tumor from $13 \%(\mathrm{G})$ to $23 \%(\mathrm{H})$

\section{* ReAction patterns of DIFFERENT Ki67-Ag antibodies}

In the cell line MCF-7 all antibodies tested gave a strong staining reaction with the highest intensity in the $\mathrm{G}_{2} / \mathrm{M}$ fraction of the cells. The Ki67-Ag could also be detected with all tested Ki67-antibodies in cryostat sections of the investigated breast tumors (Fig. 1A). In single cell suspensions prepared from the same fresh frozen clinical tumor samples the Ki67-Ag could be detected with the MIB-1 and Ki-S5 antibody, but only in three out of ten cases was a positive immunoreaction seen after immunostaining with Ki67/DAKO-PC or with the polyclonal Ki67-Ag antibody (Fig. 1B). Moreover, because this immunoreactivity was very weak these antibodies were excluded from further study. In paraffin sections of the same breast tumors only the second generation Ki67-antibodies were effective (MIB-1, Ki-S5 and poly-Ki67; see Fig. 1C). In single cell suspensions from paraffin embedded tissues, the Ki67-Ag could only be detected in all cases with Ki-S5. Examination of the cells isolated from paraffin blocks and 
immunostained by Ki-S5 using fluorescence microscopy revealed the typical Ki67immunoreactivity patterns, i.e. a diffuse nuclear staining with strong accentuation of the nucleoli (Fig. 2A-B). Mitotic cells showed strong Ki67-staining at the periphery of the condensed chromosomes (Fig. 2C-F). Virtually no background-staining was observed. As known from our previous study ${ }^{14}$, cells isolated following this protocol also retain cytokeratin remnants, which enables the simultaneous detection of the intermediate filament protein and the Ki67-Ag, as depicted in Fig. 3. FCM-analysis of these triple labeled cells (Fig. 4) show the characteristic Ki67- $\mathrm{Ag}$ staining pattern in both cytokeratin-positive as well as cytokeratin-negative cell fractions. The CVs of the $\mathrm{G}_{0} / \mathrm{G}_{1}$-peak in the DNA diploid cells were within acceptable limits (3.1 $-5.6 \%)$
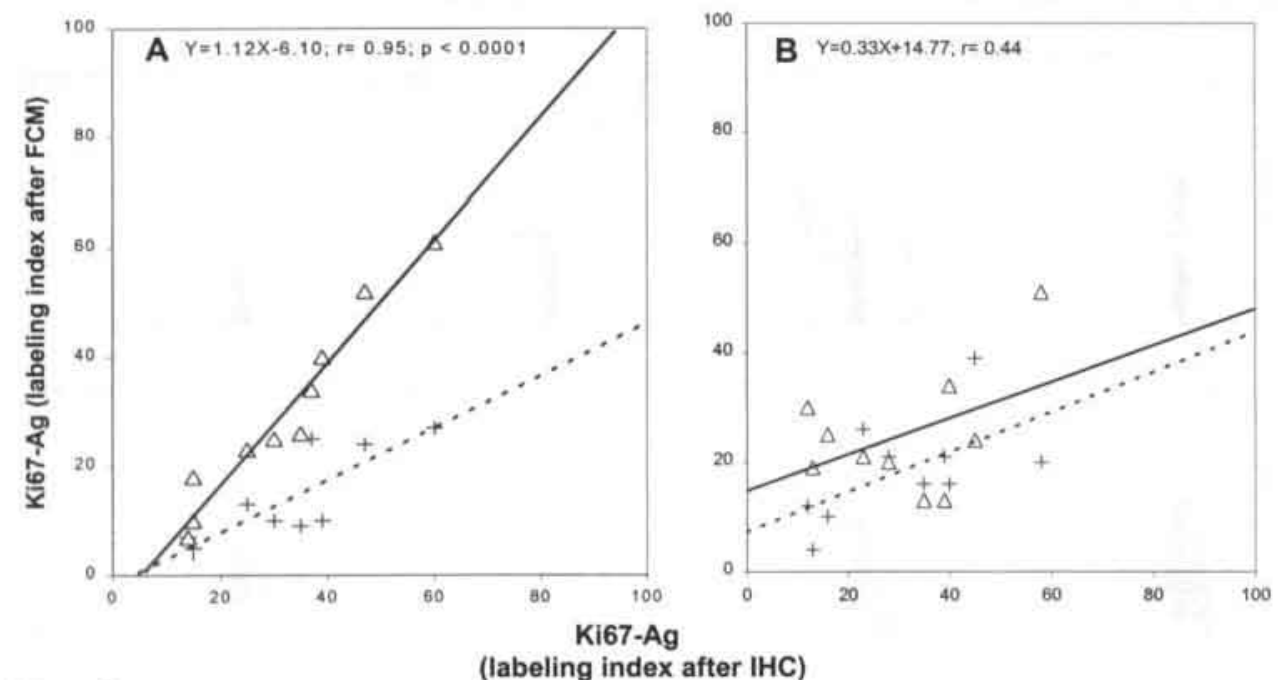

Figure 5

(labeling index after IHC)

Correlation between the relationship of the $\mathrm{Ki} 67-\mathrm{Ag}$ labeling indices as determined using the $\mathrm{Ki}-\mathrm{S} 5$ antibody in immunohistochemistry (IHC) and FCM. + indicate FCM determined labeling indices of the ungated data, while $\Delta$ indicate labeling indices after cytokeratin gating. The lines in the figures represent the best fit by linear regression (the regression equations belongs to the solid lines). A. paraffin embedded blocks and B. fresh, frozen tissue samples.

\section{* Comparison of THE KI67-Ag LABELING INDEX AS DETECTED By FLOW CYTOMETRY AND IMMUNOHISTOCHEMISTRY}

For further study, cytokeratin-expression was used to gate for the epithelial compartment of the tumor. Our next step was to determine the extent of agreement between the labeling indices as determined from a immunohistochemical staining reaction in tissue sections and the results obtained by $\mathrm{FCM}$ in the cell suspensions of the corresponding breast tumor. To quantitate the proliferative fraction in both tissue sections as well as cell suspension the Ki-S5 antibody was used. The fraction of Ki-S5-positive cells in the single cell suspensions prepared from the paraffin embedded tumors was consistently lower than the Ki67-Ag labeling index in the corresponding tissue section. However, after gating for cytokeratin-positivity, an excellent correlation was found between Ki67-Ag labeling indices in both preparations (Fig. 5A), resulting in virtually identical percentages of $\mathrm{Ki} 67-\mathrm{Ag}$ positive cells in both procedures, as indicated by a slope of 1.1 of the regression line. When frozen sections were analysed and 
compared to corresponding cell suspensions, such a correlation was not found (Fig. 5B). In the latter suspensions, the Ki67-positive fraction of the cytokeratin-gated epithelial cells was in most of the cases smaller than the Ki67-labeling index in paraffin embedded tissue.

\section{Discussion}

The immunohistochemical detection of Ki67- $\mathrm{Ag}$ has become a standard procedure for the assessment of degree of cell proliferation in tumors. Flow cytometry can provide a quantitative measurement of the DNA content of large numbers of cells in a relatively short time. Combination of these methods allows a rapid and more precise quantification of the Ki67-Ag immunopositive cells. Furthermore, by using cytokeratin antibodies in a bivariate or trivariate FCM analysis it is possible to study selectively the epithelial (cancer) cells in fresh frozen ${ }^{4,17}$, or in formalin fixed, paraffin embedded samples ${ }^{8,13,14}$. Recently, Schutte et al. ${ }^{17}$ presented a three-parameter flow cytometric assay based on the simultaneous detection of cytokeratin, DNA and proliferation associated antigens, among which was the Ki67- $\mathrm{Ag}$. The protocol was, however, restricted to fresh or fresh frozen tissue samples. The aim of the present study was to investigate whether or not this technique could also be applied to cell suspensions prepared from routinely processed paraffin embedded tissue samples. For this purpose, a panel of different antibodies directed against the Ki67-Ag was tested in combination with several enzymatic digestion protocols to prepare a single cell suspension from paraffin embedded tissue blocks. Using trypsin-digestion the single cells had retained enough cytoplasm to allow their FCM recognition as epithelial cells, while the Ki-S5 antibody still gave a strong staining reaction. Apparently, the Ki-S5 epitope resists formalin fixation and tryptic digestion, in contrast to the epitopes recognized by the other three Ki67-Ag antibodies. In interphase cells the most intense staining reaction of $\mathrm{Ki}-\mathrm{S} 5$ was seen in nucleoli, while in mitotic cells this immunoreactivity was restricted to the chromosomal periphery. These findings prove that the Ki67- $\mathrm{Ag}$ can be detected in single cell-suspensions prepared from routinely processed paraffin embedded tissue. Flow cytometric analysis of these suspensions showed a range of fluorescence intensities corresponding to a steady increase of Ki-S5 immunoreactivity during the $\mathrm{G}_{1}$ - and S-phase, resulting in the highest intensity in $\mathrm{G}_{2} / \mathrm{M}$-phase cells.

Only after gating for cytokeratin-positivity was an almost perfect 1:1 linear correlation found between the Ki-S5-positive fraction obtained with FCM of cell suspensions prepared from paraffin blocks and the number of Ki-S5-positive tumor cells determined in paraffin sections of the same tumor. Thus, cytokeratin gating in the three-parameter FCM analysis resulted in virtually identical $\mathrm{Ki} 67-\mathrm{Ag}$ labeling indices as compared to the quantification based on the immunohistochemical staining reaction in paraffin sections of solid breast carcinomas.

Although the disaggregation procedure applied to the paraffin sections is difficult to control, with respect to selective retrieval of cells and cytokeratin-epitope digestion, our results clearly indicate that these phenomena are of minor importance for the outcome of the FCM analysis.

In cell suspensions prepared from the fresh frozen tumor, a consistently lower Ki67-Agpositive fraction was found. An explanation for this finding could be that the Ki67-epitope is partially degraded by proteolytic enzymes which are released when thawing and mechanically dissagregating the frozen tissue block. In concordance with this line of reasoning is the observation of Buckley et $\mathrm{al}^{2}$ who showed that the Ki67- $\mathrm{Ag}$ immunoreactivity deteriorates 
even when the tissue is stored in liquid nitrogen. Also, the findings of Kreipe et al ${ }^{11}$, who saw higher Ki-S5 labeling indices in paraffin sections as compared to the cryostat sections of the same tumor, suggest partial lost of Ki67-Ag epitope in fresh frozen tissue.

In conclusion, this study shows that the proliferative fraction of cell suspensions from breast tumors can be reliable determined by a threeparameter cytokeratin/Ki67-Ag/DNA FCManalysis using the Ki-S5 monoclonal antibody on formalin fixed, paraffin embedded tissue. Virtually identical Ki67-Ag-positive fractions are obtained by FCM as compared to the conventional immunohistochemical quantification procedure of tissue sections. In fact, besides the advantage that retrospective studies can be performed, the results obtained from these paraffin embedded tissue samples are more reliable than results obtained from analysis of frozen tissue, because formalin fixation limits degradation of the Ki67-Ag. The FCM method has the advantage of a faster and more precise quantification of immunolabeled cells. Furthermore, information about DNA ploidy level and cell cycle distribution of the relevant (cytokeratin positive) tumor cells are obtained. 


\section{References}

1. Barnard NJ, Hall PA, Lemoine NR, Kadars N. Proliferative index in breast carcinoma determined in situ by Ki67 immunostaining and its relationship to clinical and pathological variables. J Pathol 1987; 152: 287-295

2. Buckley C, Magee H, Dervan PA. Ki-67 immunoreactivity is retained in acetone-fixed cryostat sections stored at 20EC. Int J Surg Pathol 1993; 1: 135-138

3. Corson JM. Keratin protein immunohistochemistry in surgical pathology practice. Pathol Annu 1986; 21 (part 2): 47. 81

4. Feitz WFJ, Beck HLM, Smeets AWGB, Debruyne FMJ, Vooijs GP, Herman CJ, Ramaekers FCS. Tissue specific markers in flow cytometry of urological cancers: cytokeratins in bladder carcinoma. Int J Cancer 1985; 36: 349-356

5. Gerdes J, Schwab U, Lemke H, Stein H. Production of a mouse monoclonal antibody reactive with a human nuclear antigen associated with cell proliferation. Int J Cancer 1983; 31: 13-20

6. Gerdes J, Lemke H, Baisch H, Wacker H-H, Schwab U, Stein H. Cell cycle analysis of a cell-proliferation associated human nuclear antigen defined by the monoclonal antibody Ki-67. J Immunol 1984; 133: 1710-1715

7. Gerdes J, Becker MHG, Key G. Immunohistological detection of tumour growth fraction (Ki-67 antigen) in formalinfixed and routinely processed tissues. J Pathol 1992; 168: 85-87

8. Glogovac JK, Porter PL, Banker DE, Rabinovitch PS. Cytokeratin labeling of breast cancer cells extracted from paraffin-embedded tissue for bivariate flow cytometric analysis. Cytometry 1996; 24: 260-267

9. Hedley DW, Clark GM, Cornelisse CJ, Killander D, Kute T, Merkerl D. Consensus review of the clinical utility of DNA cytometry in carcinoma of the breast. Cytometry 1993; 14:482-485

10. Key G, Larsen Petersen J, Becker MHG, Duchrow M, Schlhter C, Askaa J, Gerdes J. New antiserum against Ki67 antigen suitable for double immunostaining of paraffin wax sections. J Clin Pathol 1993; 46: 1080-1084

11. Kreipe H, Wacker HH, Heidebrecht HJ, Haas K, Hauberg M, Tiemann M, Parwaresch R. Determination of the growth fraction in Non-Hodgkin's lymphomas by monoclonal antibody Ki-S5 directed against a formalin-resistant epitope of the Ki-67 antigen. Am J Pathol 1993; 142: 1689-1694

12. Landberg G, Roos G. Flow cytometric analysis of proliferation associated nuclear antigens using washless staining of unfixed cells. Cytometry 1992; 13: 230-240

13. Leers MPG, Theunissen PHMH, Koudstaal J, Schutte B, Ramaekers FCS. Trivariate flow cytometric analysis of paraffin-embedded lung cancer specimens: Application of cytokeratin subtype specific antibodies to distinguish between differentiation pathways. Cytometry 1997; 27:179-188

14. Leers MPG, Theunissen PHMH, Schutte B, Ramaekers FCS. Bivariate cytokeratin/DNA flow cytometric analysis of paraffin embedded samples of colorectal carcinomas. Cytometry 1995, 21: 101-107

15. Overbeck J von, Stähli C,Gudat F, Carmann H, Lautenschlager C, Dürmüller U, TaKacks B, Miggiano V, Staehelin T, Heitz PU. Immunohistochemical charcterization of an anti-epithelial monoclonal antibody (mAb lu-5). Virchows Arch (Pathol Anat) 1985; 407:1-12

16. Schutte B, Reynders MMJ, Bosman FT, Blijham GH. Studies with antibromodeoxyuridine antibodies, II Simultaneous detection of antigen expression and DNA synthesis by in vivo labeling of mouse intestinal mucosa. J Histochem Cytochem 1987; 35: 371-374

17. Schutte B, Tinnemans MMFJ, Pijpers GFP, Lenders MHJH, Ramaekers FCS. Three parameter flow cytometric analysis for simultaneous detection of cytokeratin, proliferation associated antigens and DNA content. Cytometry 1995; 21: 177-186

18.Zarbo RJ, Visscher DW, Crissman JD. Two-color multiparametric method for flow cytometric DNA analysis of carcinomas using staining for cytokeratin and leucocyte-common antigen. Anal Quant Cytol Histol 1989; 11:391-402 



\section{Heat pretreatment increases resolution in DNA flow cytometry of paraffin embedded tumor tissue}

M.P.G. LEERS ${ }^{1}$, B. SCHUTtE ${ }^{2}$, P.H.M.H. THEUNISSEN', F.C.S RAMAEKERS ${ }^{2}$, M. NAP'

${ }^{1}$ Department of Pathology, atrium medical Centre, heerlen and ${ }^{2}$ Department of molecular Cell BIOLOGY \& GENETICS, MAASTRICHT UNIVERSITY, THE NETHERLANDS

CYTOMETRY 1999; 35: 260-266 


\section{Abstract}

Background: Flow cytometry of single cell suspensions prepared by enzymatic digestion from formalin fixed, paraffin embedded tissue suffers from several major drawbacks. Most important factors that influence the results are the high and unpredictable coëfficients of variation $(\mathrm{CVs})$ of the $\mathrm{G}_{0} / \mathrm{G}_{1}$ peak in the DNA histogram and reduction of propidium iodide (PI) intercalation with DNA, resulting from protein cross-linking by formalin.

Methods: In this study we introduce a heating step ( 2 hrs incubation in citrate solution at $80^{\circ} \mathrm{C}$ ) prior to a brief pepsin digestion of tissue sections in the protocol for DNA content analysis of formalin fixed and paraffin embedded tissue. This new method is compared with established methods for the preparation of cell suspensions from frozen and paraffin embedded tissues with respect to cell yield, DNA histogram resolution, DNA dye saturation kinetics, cell cycle parameters, and antigen retrieval in various epithelial and non-epithelial tissues.

Results: The recovery of single cells from the paraffin sections was doubled by the heat treatment step, while the limited time of proteolysis resulted in a decreased cell debris. Furthermore an increased fraction of cells became cytokeratin positive while these immunocytochemically stained cells also exhibited a higher mean fluorescence intensity. The DNA histograms prepared from cell suspensions obtained according to this new protocol showed a significantly improved resolution, leading to a better identification of peridiploid cell populations. Heat pretreatment of paraffin embedded archival tissue sections showed PI saturation kinetics similar to, or even better than fresh unfixed tissues, independent of the duration of fixation.

Conclusions: This new method, making use of routinely available antigen retrieval principles, thus allows high resolution DNA analysis of routinely fixed and paraffin embedded tissue samples. Using external reference cells inter- and intralaboratory standardization of DNA histograms can be achieved.

\section{Introduction}

The use of flow cytometry (FCM) to measure DNA ploidy in tumor cells is standardized for use on fresh or frozen cells, using erythrocytes from chicken and/or trout as reference cells ${ }^{23}$. Paraffin-embedded tissue can be used for flow cytometric DNA analysis since Hedley and coworkers ${ }^{10}$ described a method to prepare single-cell suspensions from such archival material using a pepsin digestion step after dewaxing and rehydrating thick tissue sections. A large number of studies using their protocol has since been published, and consensus reviews on the prognostic significance of ploidy status and S-phase fraction thus obtained are emerging ${ }^{3,7.11 .12 .21}$.

Despite the advantages of retrospective analyses, there are major drawbacks to this technique. The DNA-histograms of the single cell suspensions prepared from paraffin blocks are generally of poor quality as compared to those derived from fresh tissue samples of the same tumor. Cell suspensions often contain excessive debris and DNA histograms show asymmetric distribution and high coefficients of variation $(\mathrm{CVs})^{20}$. For this reason many modifications to 
the original method of Hedley et al ${ }^{10}$ have been introduced to improve DNA-histogram quality, e.g. variation in the thickness of the tissue section, and choice of various enzymes for tissue dissociation (trypsin, neutral protease, proteinase $K$ ) ${ }^{8,11,13,18,19}$. However, due to the cross-linking effect of formalin on proteins, the uptake of DNA intercalating dyes will be reduced and many antigens will become masked ${ }^{14}$. Enzymatic digestion improves nuclear dye uptake, but still results in variable dye saturation, depending on the time of formalin fixation. Since many pathology laboratories do not control fixation conditions routinely, standardization of DNA histograms of formalin fixed, paraffin embedded material is not possible, unless non-tumor tissue present within the same sample can be used as the diploidy standard ${ }^{19}$.

A variety of protocols have been developed for antigen retrieval in routine immunohistology. Most of these protocols make use of heat applied to paraffin embedded tissue sections in a citrate solution to reverse the effects of formalin fixation. In this way, the immunoreactivity of epitopes for many monoclonal antibodies can be restored $5,22,24$. In the present study we investigated whether a similar principle could be applied for the preparation of a single cell suspension for DNA flow cytometry, and if so, whether heat pretreatment could overcome the adverse effects of formalin fixation in this respect. To this end deparaffinized and rehydrated tissue sections were heated for two hours at $80^{\circ} \mathrm{C}$ in citrate solution followed by a brief pepsin digestion. The results of this new protocol are compared to those of two established methods for the preparation of cell suspensions from frozen and paraffin embedded tissues, in particular with respect to cell recovery and generation of cell debris, DNA histogram resolution, PI saturation kinetics and anti-cytokeratin immunofluorescence.

\section{Materials and methods}

\section{* SAMPLE PREPARATION}

\section{A. FRESH FROZEN TISSUE}

Tissue samples ( $\mathrm{n}=11 ; 7$ breast carcinomas, 1 colorectal carcinoma, 2 samples of normal colon tissue and 1 benign meningeoma) were collected during surgery and immediately processed for this study. From each tissue specimen, a representative sample was snap frozen in liquid nitrogen and stored at $-70^{\circ} \mathrm{C}$. For FCM analysis this part was mechanically disaggregated by mincing with scalpel blades, after thawing of the tissue in phosphate buffered saline, $\mathrm{pH} 7.4$ (PBS). Before fixation the suspension was filtered through a $50 \mu \mathrm{m}$ nylon mesh. To $100 \mu \mathrm{l}$ suspension of single cells (approximately $10^{6}$ cells in $100 \mu \mathrm{l}$ PBS) $3 \mathrm{ml}$ of cold absolute methanol $\left(-20^{\circ} \mathrm{C}\right)$ was added for fixation and permeabilisation. After 10 minutes incubation at room temperature the methanol was removed by centrifugation and the cell pellet rinsed in PBS supplemented with $1 \mathrm{mg} / \mathrm{ml}$ bovine serum albumin (PBS/BSA; Sigma, St.Louis, MO, USA).

\section{B. FORMALIN FIXED, PARAFFIN EMBEDDED TISSUE}

From the same tissue specimens a representative part was immediately fixed in $4 \%$ buffered formalin ( $\mathrm{pH} 7.4)$ for exactly 24 hours, and then routinely processed for paraffin embedding. From each of the paraffin blocks, four $50 \mu \mathrm{m}$ thick tissue sections were cut and divided over two glass tubes. These sections were deparaffinized in xylene and rehydrated in a descending 
ethanol series. The sections in the first glass tube were treated for 80 minutes with $1 \mathrm{mg} / \mathrm{ml}$ pepsin (Sigma) in $0.1 \mathrm{~N} \mathrm{HCl}$ at $37^{\circ} \mathrm{C}^{13}$. The sections in the second tube were immersed in cold citrate solution $(2 \mathrm{mg}$ citric $\mathrm{acid} / \mathrm{ml}$ aqua dest, $\mathrm{pH}=6.0)$ and placed in a water bath at $80^{\circ} \mathrm{C}$ for $2 \mathrm{hr}$. After a 15 minutes cooling period to room temperature the sections were rinsed in PBS, and thereafter digested in a $1 \mathrm{mg} / \mathrm{ml}$ pepsin solution (Sigma) in $0.1 \mathrm{~N} \mathrm{HCl}$ at $37^{\circ} \mathrm{C}$ for 15 minutes. The samples were then filtered through a $50 \mu \mathrm{m}$ mesh nylon filter. The pepsin was washed out by centrifugation at $400 \mathrm{~g}$ and the pellet was resuspended in PBS/BSA. An additional group of 42 breast carcinomas was analysed using the heating method as described above.

\section{* PROPIDIUM IODIDE (PI) SATURATION KINETICS}

In order to study the effect of the heat treatment step on PI saturation kinetics, a fresh breast tumor sample was divided into two parts. One part was mechanically disaggregated, the cell suspension fixed for 15 minutes in cold methanol $\left(-20^{\circ} \mathrm{C}\right)$, and washed in PBS. The other part was routinely processed for paraffin embedding. From the paraffin block four $50 \mu \mathrm{m}$ thick sections were cut and divided over two glass tubes. Aliquots of the cell suspension obtained with the two methods described above and containing approximately $1 \times 10^{6}$ cells were incubated at final PI concentrations of $100,50,25,10,5$ and $2.5 \mu \mathrm{g} / \mathrm{ml}$, respectively.

\section{* EFFECT OF FIXATION TIME}

To examine the effect of duration of formalin fixation on DNA ploidy measurements a freshly collected breast carcinoma specimen was divided into two parts. One part was snap frozen in liquid nitrogen, whereas the other part was subdivided into five pieces. The five pieces were fixed in $4 \%$ buffered formalin pH 7.2, for 3, 24, 48, 72 and 96 hrs, respectively, and routinely processed for paraffin embedding. From the freshly frozen as well as the paraffin embedded parts single cell suspensions were prepared as described above. To each sample $0.5 \times 10^{6}$ chicken red blood cells (ethanol fixed CRBC; Becton Dickinson, San Jose, CA, USA) were added before PI staining according to the supplier's instructions. The peak ratio of CRBC and sample $\mathrm{G}_{0} / \mathrm{G}_{1}$ DNA was used to determine variations in PI uptake. After incubation with PI (5 $\mu \mathrm{g} / \mathrm{ml}$ in PBS) for 15 minutes at $4^{\circ} \mathrm{C}$ the samples were analyzed by FCM.

\section{* IMMUNOCYTOCHEMISTRY}

To examine the effect of the heating step on the recognition of cytokeratin epitopes in these cell suspensions, a bivariate FCM analysis, using the indirect fluorescein isothiocyanate (FITC)-labeled antibody technique was used. The single cell suspension was aliquoted into $100 \mu \mathrm{l}$ samples. To each sample $5 \mu \mathrm{l}$ of the cytokeratin monoclonal antibody CAM 5.2 (Becton Dickinson) was added in a 1:10-dilution. After overnight incubation at room temperature the samples were rinsed twice in PBS. Antibody binding was visualized by incubating the cell pellet with FITC-conjugated goat anti-mouse Ig, diluted 1:10 (DAKO A/S, Glostrup, Denmark). After incubation for $1 \frac{1}{2} \mathrm{hr}$ at room temperature, the samples were rinsed twice in PBS. Cells were finally counterstained with PI $(5.0 \mu \mathrm{g} / \mathrm{ml}$, Sigma $)$ in PBS containing $0.1 \mathrm{mg} / \mathrm{ml}$ RNAse (Serva, Heidelberg, Germany). The samples were allowed to stand for 15 minutes on ice in the dark before FCM analysis. As a negative control, tumor cells were stained with a mouse monoclonal antibody directed against BrdU (clone IIB5; EuroDiagnostica, Arnhem, The Netherlands). 


\section{* FLOW CYTOMETRY}

All samples were analysed using a FACScan flow cytometer (Becton Dickinson). Cells were excited with a single $488 \mathrm{~nm}$ argon laser. Fluorescein isothiocyanate (FITC) fluorescence was detected through a 515-545 nm BP filter, and PI-fluorescence through a $572-588 \mathrm{~nm}$ BP filter. Electronic gating was used to exclude doublets and cellular debris. At least 20,000 events were collected for each sample. FITC-signals were recorded as logarithmically amplified data, while the PI-signals were recorded as linearly amplified data. The following settings were used: $407 \mathrm{~V}$ and $354 \mathrm{~V}$ on photomultiplier tubes for FL1 (FITC) and FL3 (PI), respectively. A major part of data analysis was performed using Lysys II software (Becton Dickinson). For cell cycle analysis and determination of amount of background and debris ModFit LT 2.0 (Verity Software House, Inc. Maine, USA) was used. The following data were collected: the DNA index of the $\mathrm{G}_{0} / \mathrm{G}_{1}$ peak and its coefficient of variation (CV), S phase fraction, background and debris, the percentage of cytokeratin-positive cells and the mean fluorescence intensity of the cytokeratin-signal. The number of cytokeratin positive cells in the cell suspension was determined by an arbitrary threshold setting allowing not more than $5 \%$ of positive counts in the negative control, and expressed without subtraction of this unspecifically stained fraction. The relative fluorescence intensity (RFI) was calculated as the ratio of the mean fluorescence signal of the cytokeratin positive cell population of the sample as compared to that of the negative control. Cell counts to verify the recovery were performed using a hemacytometer. For obvious reasons the cell yield is expressed as number of cells per $100 \mu \mathrm{m}$ paraffin section. The above mentioned data were statistically analysed using the 'Ttest for paired samples' with use of the SPSS-software package (SPSS Inc., Chicago, II).

\section{Results}

\section{* Cell recovery}

Morphological examination of the cell suspension by fluorescence microscopy showed an intact nuclear morphology, with part of the nuclei exhibiting cytoplasmic remnants reactive with the cytokeratin antibody. The cell suspensions prepared after heating and $15 \mathrm{~min}$ pepsin digestion on average showed a teofold increase $(\mathrm{p}<0.0001)$ in the absolute number of single cells and reduction of cell debris, as compared to the cells obtained after applying protocols without heat pretreatment but with prolonged $(80 \mathrm{~min})$ pepsin digestion (Table 1). The cytokeratin positive fraction was also increased. In addition to this higher percentage of epithelial cells also the relative fluorescence intensity of the cytokeratin-labeled cells was substantially higher (Table 1). The aneuploid cytokeratin positive fraction in the cell suspensions prepared from the paraffin blocks by the heating method was almost the same as compared to the cell suspensions prepared from the fresh frozen tumor parts (mean values of $20.71 \%$ and $20.45 \%$, respectively). In the cell suspensions prepared from the paraffin blocks by the standard method this fraction was decreased (mean value of $11.52 \%$ ). The ratio between cytokeratin positive aneuploid cells and cytokeratin negative aneuploid cells from the fresh tissue samples was $0.46 / 0.54(0.85)$ whereas the heating method resulted in $0.38 / 0.62$ (0.61). For the standard method applied to the paraffin blocks this figure was $0.14 / 0.86$ $(0.16)$. 


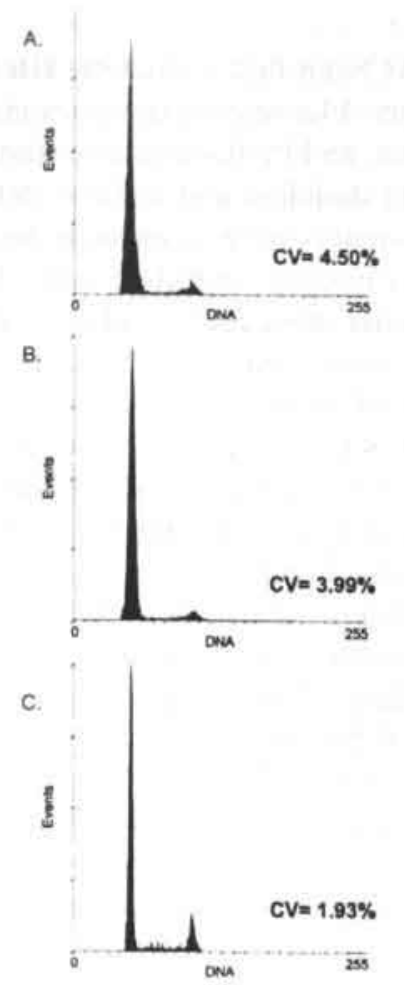

Figure 1 The effect of heating on the resolution of the DNA-histogram.

Depicted are the DNA-histograms derived from the normal colonic mucosa after releasing single cells by different preparation protocols. A. fresh frozen sample, mechanical dissociation, B and C. both formalin fixed, paraffin embedded part. B. single cells after standard pepsin digestion. C. single cells after heating the whole $50 \mu \mathrm{m}$ thick paraffin section followed by a short and mild pepsin digestion.

Table 1 Comparison of FCM data obtained by the three different methods applied to eleven samples of solid tissues

\begin{tabular}{|c|c|c|c|c|c|c|c|}
\hline & $\begin{array}{l}\text { Aneu- } \\
\text { ploidy }\end{array}$ & Cell recovery & B\&D & $\mathrm{CV}$ & $\begin{array}{l}\text { Fraction of } \\
\text { CK + cells }\end{array}$ & RFI & $\begin{array}{c}\text { SPF of } \\
\text { CK + cells }\end{array}$ \\
\hline & $\begin{array}{c}\text { No of case } \\
\text { over total no of } \\
\text { cases }\end{array}$ & $\begin{array}{c}\text { Mean } \pm S D, \\
n^{*} / O^{\prime} \text { cells/IOO } \\
\mu m \text { thick section }\end{array}$ & $\begin{array}{c}\text { Mean } \pm S D \\
\%\end{array}$ & $\%$ & $\underset{\%}{\text { Mean } \pm S D}$ & & $\begin{array}{c}\text { Mean } \pm S D \\
\%\end{array}$ \\
\hline Fresh frozen tissue & $5 / 11$ & n.d. & $16 \pm 12$ & $4.69-$ & $28.9 \pm 12.9$ & $4.39 \pm 1.8$ & $8 \pm 6$ \\
\hline FFPE, standard meth. & $5 / 11$ & $100.2 \pm 48.37$ & $26 \pm 14$ & 3.907 & $24.4 \pm 16.8$ & $2.85 \pm 1.5$ & $11 \pm 4$ \\
\hline FFPE, new method & $6 / 11^{*}$ & $213.1 \pm 101.7$ & $8 \pm 4$ & $2.56]^{+}$ & $39.6 \pm 16.6$ & $5.21 \pm 2.2$ & $7 \pm 4$ \\
\hline
\end{tabular}

* With the new method an additional peridiploid tumor was found. $\dagger=p<0.0001 ; \neq=p<=0.001$

$\mathrm{FFPE}=$ formalin fixed, paraffin embedded; $\mathrm{B} \& \mathrm{D}=$ background and debris; $\mathrm{CV}=$ coëfficient of variation; $\mathrm{CK}=$ cytokeratin; $\mathrm{RFI}=$ relative fluorescence intensity; $\mathrm{SPF}=\mathrm{S}$ phase fraction; $\mathrm{SD}=$ standard deviation; $\mathrm{n} . \mathrm{d}=$ not determined 


\section{* DNA HISTOGRAM RESOLUTION}

With respect to the resolution of the DNA histograms, significantly lower CV's were obtained after heat pretreatment of paraffin sections (mean $\mathrm{CV}=2.56$ ) as compared to the standard protocols for fresh (mean $\mathrm{CV}=4.69$, $\mathrm{p}<0.0001$ ) and paraffin embedded tissues (mean $\mathrm{CV}=$ $3.90, \mathrm{p}=<0.001$; Table 1). Representative histograms of the three different protocols are shown in figure 1. As mentioned in the Materials \& Methods section, the additional group of 42 breast carcinoma samples was only analysed after heat pretreatment. This group had a mean CV of 3.02 , slightly higher than the 2.56 from table 1 .

With the standard protocols DNA-aneuploidy was found in 5 of the 8 malignant tumor tissues. Due to the enhanced resolution of the DNA histograms after heat pretreatment, an additional peridiploid subpopulation with a DNA index of 1.06 was observed in one breast tumor sample (Fig. 2). As expected, both normal colonic mucosal tissue samples and the benign meningioma were DNA-diploid with all three protocols. The amount of debris was lowest after heat pretreatment, while the cell cycle phase distributions as determined by the S-phase fraction were similar for the new protocol and for the fresh frozen tissue protocol (Table 1).
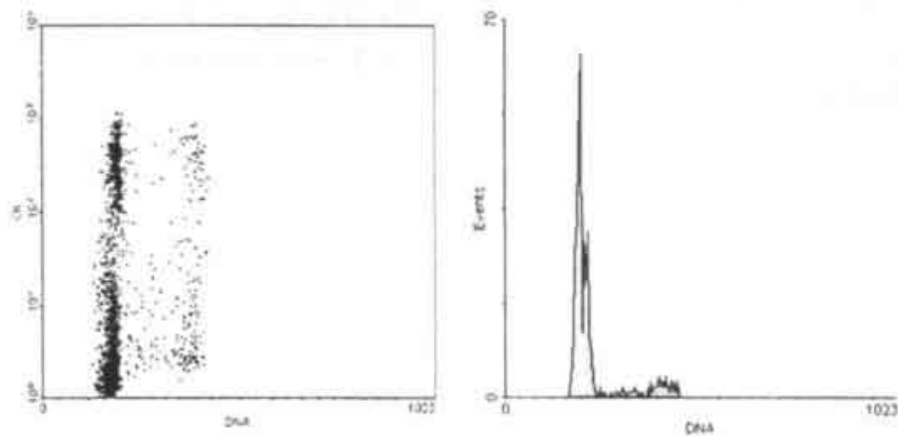

Figure 2 Flow cytometric results of a peridiploid breast carcinoma (DNA-index 1.06). In this case all cytokeratin positive cells appeared to belong to the peridiploid cell population.

\section{${ }^{*}$ KINETICS OF THE STAINING}

Since the CV of the histograms is strongly dependent on the reproducibility and efficiency of DNA staining, the DNA dye saturation kinetics was examined for the different protocols. Samples of approximately $10^{6}$ cells obtained with the different isolation protocols, were incubated with varying PI concentrations. PI binding appeared to be saturable for all three protocols, confirming stoichiometric binding. As shown before, standard digestion of formalin fixed, paraffin embedded sections resulted in a decreased PI-uptake. Heat pretreatment resulted in an even more pronounced increase in PI fluorescence as compared to non-heated tissue (Fig. 3).

We investigated whether this effect was dependent on the duration of fixation. As expected for the standard protocol for paraffin embedded tissues, prolonged fixation resulted in an increased variation of the ratio of PI uptake of CRBC and the sample $G_{0} / G_{1}$ cells (peak ratio variability of $0.8-1.7 \%$ ). In contrast, a significantly smaller variation in peak ratio was observed for the different fixation periods after heat pretreatment (variability of $0.1-0.2 \%$; figure 4). In fact the variation in peak ratio was similar to measurements of fresh samples from 
the same tissue, although the absolute value of the peak ratio differed slightly between the two protocols.
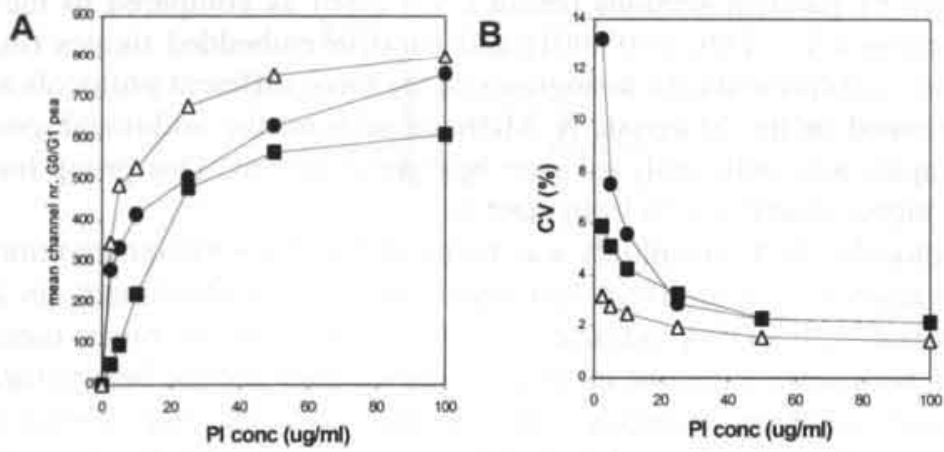

Figure 3 PI saturation and CV's of a diploid breast carcinoma sample. The single cells were prepared from fresh frozen ( ) or formalin fixed, paraffin embedded tissues. From the paraffin embedded part single cells were prepared by the standard pepsin-digestion method ( $\mathbf{a}$ ) and by the heating/brief pepsin-digestion method ( $\Delta$ ). The cells were stained with increasing concentrations of PI.

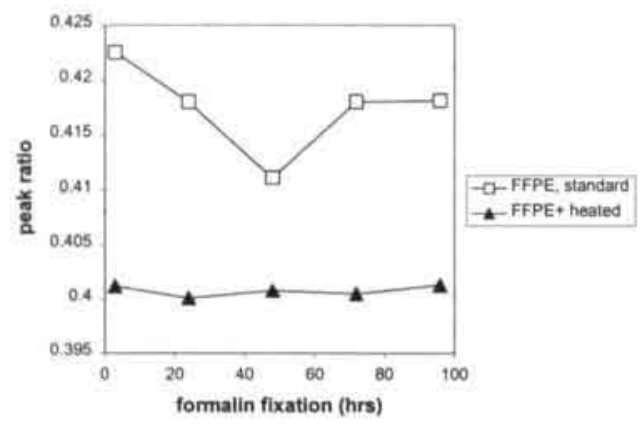

Figure 4 Influence of fixation on the DNA peak ratio of chicken red blood cells (CRBC) and the $\mathrm{G}_{0} / \mathrm{G}_{1}$ of sample diploid cells

\section{Discussion}

Since Hedley and coworkers described in 1983 a method for DNA flow cytometry of single cell suspensions prepared from paraffin embedded tissue ${ }^{12}$, many modifications of the original method have been described. However, until now these modifications have resulted only in minor improvements. The major drawback of using archival material in FCM is the adverse effect of formalin fixation on the quality of the DNA histograms. Formalin fixation results in the formation of methylene bridges between amino groups in the DNA and/or proteins. This cross-linking results in a reduced and variable nuclear dye uptake and results therefore in a reduced resolution of the DNA histograms as compared to fresh, unfixed tissues. 
An important issue that must be adressed in the assessment of FCM DNA analysis of solid tumors is whether the tissue disaggregation method releases enough cells representative of the tumor cell population. In this study it has been shown that the heating method gives a cell recovery twice as high as compared to the standard method.

Secondary, but not less important in solid tumor FCM DNA analysis is the achievement of optimum DNA histogram resolution. Formalin fixation has an adverse effect on the quality of the DNA histogram. For many years antigen retrieval methods have been used to increase the quality of immunohistochemistry to be applied to paraffin embedded tissue sections. Although their mechanisms of action are largely unknown, these antigen retrieval methods seem to reverse the effect of formalin fixation and have been shown to restore immunoreactivity for a wide variety of antigens. By heat pretreatment of dewaxed tissue sections, prior to mild proteolytic digestion, we have shown that not only cell recovery is improved but also that the adverse effects of formalin fixation on nuclear dye uptake are counteracted. Probably as a consequence of this effect the CV's of the DNA histograms were significantly lower as compared to the standard protocol and even as compared to fresh frozen tissue samples.

In line with our results, Hasselkorn et al ${ }^{9}$ described a partial reversal of the effect of formalin fixation on the UV absorbance of polynucleotides by heating the fixed polynucleotides in phosphate solution at $75^{\circ} \mathrm{C}$. Recently, Overton et al ${ }^{17}$ described a partial reversion of the effect of formalin fixation on the binding of PI to DNA. These authors first prepared a single cell suspension by trypsin digestion after which they heated this cell suspension for 90 minutes at $75^{\circ} \mathrm{C}$ in PBS. In our study, the intact $50 \mu \mathrm{m}$ thick deparaffinized, rehydrated tissue section was heated for $2 \mathrm{hrs}$ at $80^{\circ} \mathrm{C}$ in a citrate solution before a short and mild enzymatic digestion. This preparation method showed that the effect on the nuclear fluorescence intensity of formalin fixation could be completely neutralized. In fact the fluorescence intensity even increased as compared to that of the cells prepared from the fresh frozen part of the tissue. The increase in nuclear PI fluorescence intensity can be explained by the fact that the tissue sections are heated in a citrate solution. Heating cells in acidic environment leads to extraction of chromatin proteins ${ }^{4.6}$. As a result more binding sites become available. This might also explain the finding that the CV of DNA histograms after the heating method was even smaller than that of the cell suspensions prepared from the fresh frozen part. Variations in temperature of $10^{\circ} \mathrm{C}$ above or below the $80^{\circ} \mathrm{C}$, resulted in poor quality of the DNAhistograms due to higher CVs (data not shown). A heating temperature of more than $80^{\circ} \mathrm{C}$ resulted in denaturation of cells while lower temperatures resulted in a partial reversion of the formalin fixation and a decrease in the immunoreactivity for cytokeratin.

Many studies have shown that the length of fixation time plays an important role in the variability which is seen in the determination of the DNA-ploidy status of a tumor. Schutte et al. found more intersample variability in paraffin embedded tissue when compared to fresh tissue ${ }^{19}$. They concluded that this difference was related to the length of fixation time, with increased variability associated with prolonged fixation. We were able to reconfirm this finding when a cell suspension was prepared from the paraffin blocks by the enzymatic digestion method. However, when the cell suspension was prepared by the new method the variability in DNA-index due to fixation time decreased almost to zero. Because fixation time has no influence anymore on the determination of the ploidy status of a tumor when using the new method, intra- and interinstitutional exchange of FCM-investigations can be performed. In the absence of internal control cells, fresh diploid cells or other reference cells can now be 
used as an internal control to standardize the DNA-flow cytometry of formalin fixed, paraffin embedded (FFPE) tissues.

The combination of heating and citrate solution is a widely used technique for antigen retrieval in immunohistochemistry of FFPE tissue ${ }^{5,22,24}$. One of the most reasonable explanations for the mechanism of heat-induced antigen retrieval is that the heat applied to the tissue sections may provide the energy which is necessary to break cross-links that have been formed during the formaldehyde fixation between calcium ions or other divalent metal cations and proteins ${ }^{15}$. The buffer in which the sections are heated either precipitates or chelates the released metal ions. Also the three-dimensional structure of the proteins will be restored into their native form. Enzymatic digestion also breaks down the cross-links formed during the formalin fixation. However, it does not restore the three-dimensional structure of the antigenic epitopes but it acts through destruction. Many monoclonal antibodies benefit from the use of heat-induced antigen retrieval and show an improved immunoreactivity in paraffin sections 5 . One of those monoclonal antibodies is used in this study: the cytokeratin antibody CAM5.2. This explains in part the higher RFI of the cytokeratin-signal of the cells prepared after heating the tissue sections as compared to the cells prepared according to the standard method. Although we were surprised to find cytokeratin-immunoreactivity in a meningeoma, a nonepithelial tumor, immunoreactivity for cytokeratins in these tumors was also observed by Artlich et $\mathrm{al}^{2}$. They found that meningeomas contain cytokeratins in more than $30 \%$ of the cases. Combined use of immunohistochemistry for morphological distribution patterns and FCM might therefore still be important when interpreting FCM results.

The cytokeratin-positive fraction was smallest when the cell suspension was prepared from the paraffin embedded block by the standard method. This finding was also observed by Frei et al . The destructive way in which the enzymatic cleavage acts on the tissue might be responsible in part for loss of epitopes on the epithelial cells. However, when the cell suspension was prepared by the new method the cytokeratin positive fraction was even larger than that of the cell suspension prepared from the fresh frozen part of the same tissue sample. A possible explanation for this observation might be that because of the restoration of the threedimensional structure, next to the reversal of the cross-linking due to the formalin fixation, less time is necessary to break down the cell-cell contacts by enzymatic digestion. It therefore seems to be of crucial importance that the heating step is adequately carried out and precedes the enzymatic digestion. Although cells will be lost during all methods of preparations, the heating method approaches the results of the cell yield obtained from the fresh frozen tissue samples.

In conclusion, this simple and efficient method for isolation of cells from paraffin sections results in:

1. Increased cell recovery and decreased cell debris, making smaller tumor samples accessible for flow cytometric analysis.

2. The improved saturation kinetics of PI allowed an improved resolution of the DNA histogram with a reduced $\mathrm{CV}$ for $\mathrm{G}_{0} / \mathrm{G}_{1}$-peaks.

3. Increased immunoreactivity of epithelial tumor cells for cytokeratin antibodies.

4. The use of external reference cells in this method will facilitate the standardisation of FCM on paraffin embedded tissue and improve the exchange of results between diagnostic laboratories. 


\section{References}

1. Arber DA, Cook PD, Moser LK, Speights VO. Variation in reference cells for DNA analysis of paraffin embedded tissue. Am J Clin Pathol 1992; 97; 387-392

2. Artlich A, Schmidt D. Immunohistochemical profile of meningeomas and their histological subtypes. Hum Pathol 1990; 21: 843-849

3. Bauer KD, Bagwell B, Giaretti W, Melamed M, Zarbo RJ, Witzig TE, Rabinovitch PS. Consensus review of the clinical utility of DNA flow cytometry in colorectal cancer. Cytometry 1993; 14: 486-491

4. Beisker W, Dolbaere F, Gray JW. An improved immunocytochemical procedure for high-sensitivity detection of incorporated bromodeoxyuridine. Cytometry 1987: 8: 235-239

5. Cattoretti G, Suurmeijer AJH. Antigen unmasking on fromalin-fixed, paraffin embedded tissues using microwaves: a review. Adv Anat Pathol 1995; 2: 2-9

6. Dolbaere F, Gray JW. Use of restriction endonucleases and exonuclease III to expose halogenated pyrimidines for immunochemical staining. Cytometry 1988: 9:631-635

7. Duque RE, Andreeff M, Braylan RC, Diamond LW, Peiper SC. Consensus review of the clinical utility of DNA flow cytometry in neoplastic hematopathology. Cytometry 1993; 14:492-496

8. Frei JV, Martinez J. DNA flow cytometry of fresh and paraffin-embedded tissue using cytokeratin staining. Mod Pathol 1993; 6: 599-605

9. Hasellkorn R, Doty P. The reaction of formaldehyde with polynucleotides. J Biol Chem 1961; 236: 2738-2745

10. Hedley DW, Friedlander ML, Taylor IW, Rugg CA, Musgrove EA. Method for analysis of cellular DNA content of paraffin embedded pathological material using flow cytometry. J Histochem Cytochem 1983; 31: 1333-1335

11. Hedley DW. Flow cytometry using paraffin-embedded tissue: five years on. Cytometry 1989: 10: 229-241

12. Hedley DW, Clark GM, Cornellise CJ, Killander D, Kute T, Merkel D. Consensus review of the clinical utility of DNA cytometry in carcinoma of the breast. Cytometry 1993; 14:482-485

13. Leers MPG, Theunissen PHMH, Schutte B, Ramaekers FCS. Bivariate cytokeratin/DNA flow cytometric analysis of paraffin embedded samples from colorectal carcinomas. Cytometry 1995;21: 101-107

14. Leers MPG, Theunissen PHMH, Ramaekers FCS, Schutte B. Multiparameter flow cytometric analysis with detection of the Ki67-Ag in paraffin embedded mammary carcinomas. Cytometry 1997; 27: 283-289

15. Morgan JM, Navabi H, Schmid KW Jasani B. Possible role of tissue-bound calcium ions in citrate-mediated hightemperature antigen retrieval. J Pathol 1994; 147: 301-307

16. Overton WR, McCoy JP. Reversing the effect of formalin on the binding of propidium iodide to DNA. Cytometry 1994: $16: 351-356$

17. Overton WR, Catalano E, McCoy JP. Method to make paraffin-embedded breast and lymph tissue mimic fresh tissue in DNA analysis. Cytometry 1996: 26: 166-171

18. Schultz DS, Zarbo RJ. Comparison of eight modifications of Hedley's method for flow cytometric DNA ploidy analysis of paraffin-embedded tissue. Am J Clin Pathol 1992; 98: 291-295

19. Schutte B, Reynders MM, Bosman FT, Blijham GT. Flow cytometric determination of DNA ploidy level in nuclei isolated from paraffin-embedded tissue. Cytometry $1985 ; 6: 26-30$

20. Shankey TV, Rabinovitch PS, Bagwell B, Bauer KD, Duque RE, Hedley DW, Mayall BH, Wheeles L. Guidelines for implementation of clinical DNA cytometry. Cytometry 1993; 14:472-477

21. Shankey TV, Kallioniemi OP, Koslowski JM, Lieber ML, Mayall BH, Miller G, Smith GJ. Consensus review of the clinical utility of DNA content cytometry in prostate cancer. Cytometry 1993; 14:497-500

22. Shi SR, Key ME, Kalra KL. Antigen retrieval in formalin fixed, paraffin embedded tissues: an enhancement method for immunohistochemical staining based on microwave oven heating of tissue sections. J Histochem Cytochem 1991; 39: $741-74$

23. Vindeløv LL, Christensen U. A review of techniques and results obtained in one laboratory by an integrated system of methods designed for routine clinical flow cytometric DNA analysis. Cytometry 1990; 11: 753-770

24. Werner M, Wasielewski von R, Komminoth P. Antigen retrieval, signal amplification and intensification in immunohistochemistry. Histochem Cell Biol 1996; 105: 253-260 



\section{Immunocytochemical detection and mapping of a cytokeratin 18 neo-epitope exposed during early apoptosis}

M.P.G. LeERS ${ }^{1}$, W. KOLGEN², V. BJORKLUND ${ }^{3}$, T. BERgMAN ${ }^{4}$, G. TRIBBICK ${ }^{5}$, B. PERSSON ${ }^{4}$, P. BJÖRLUUND ${ }^{3}$, F.C.S. RAMAEKERS $^{2}$, B. BJORKLUND ${ }^{6}$, M. NAP ${ }^{1}$, H. JORNVALL ${ }^{4}$ \& B.SCHUTTE ${ }^{2}$

'Department of Pathology, Atrium Medical Centre, HeERlen, THE NetHerlands, ${ }^{2}$ Department of MOLECULAR CELL BIOLOGY \& GENETICS, UNIVERSITY OF MAASTRICHT, THE NETHERLANDS, ${ }^{3}$ BEKI DIAGNOSTICS AB, FREDSFORSSTIGEN 22, S-168 66 BROMMA, SWEDEN, ' DEPARTMENT OF MEDICAL BIOCHEMISTRY AND BIOPHYSICS, KAROLINSKA INSTITUTET, S-171 77 STOCKHOLM, SWEDEN, ${ }^{5}$ CHIRON TECHNOLOGIES PTY LTD, 11 DUERDIN STREET, CLAYTON, VICTORIA 3168, AUSTRALIA AND ${ }^{6}$ CANCER COUNCIL, FREDSFORSSTIGEN 22, S-168 66 BROMMA, SWEDEN 


\section{Abstract}

A neo-epitope in cytokeratin 18 (CK18) that becomes available at an early caspase cleavage event during apoptosis and is not detectable in vital epithelial cells is characterized. The monoclonal antibody M30, specific for this site, can be utilized specifically to recognize apoptotic cells, which show cytoplasmic cytokeratin filaments and aggregates after immunohistochemistry with M30, while viable and necrotic cells are negative. The number of cells recognized by the antibody increases after induction of apoptosis in exponentially growing epithelial cell lines and immunoreactivity is independent of the phosphorylation state of the cytokeratins. The generation of the M30 neo-epitope occurs early in the apoptotic cascade, before annexin V reactivity or positive DNA nick end labelling. In a flow cytometric assay, the majority of the M30-positive cells appears in the 'apoptotic' subG1-peak. Tests with synthetic peptides define positions 387-396 of CK18, with a liberated C-terminus at the caspase cleavage site DALD ${ }^{\star} \mathrm{S}$, as the 10-residue epitope of M30. This epitope starts at the end of coil 2 of the predicted CK18 structure, at a probable hinge region, compatible with the sensitivity to proteolytic cleavage. The definition of a specific caspase cleavage site in CK18 as a neo-epitope can be used for quantification of apoptotic epithelial cells with immunocytochemical techniques and is applicable to both fresh and formalin-fixed material.

\section{Introduction}

Apoptosis is a biochemically and morphologically distinct form of programmed cell death, initiated by specific signals that activate specific caspases ${ }^{3}$. As a result, the cell is eliminated by an intrinsic suicide program, resulting in DNA fragmentation, nuclear condensation, cytoskeletal reorganization, plasma membrane blebbing and loss of cell adhesion ${ }^{8}$. Methods widely used to identify apoptotic cells are light and electron microscopy, flow cytometry ${ }^{4}$, agarose gel DNA electrophoresis, in situ nick-end labeling (ISEL), TdT-mediated dUTP nick end labeling (TUNEL) ${ }^{7}$, and recent methods based on the detection of phosphatidylserine (PS) in the outer plasma membrane using annexin $\mathrm{V}^{6}$. In studies aimed at the production of monoclonal antibodies directed to cytokeratin 18 (CK18), we noticed that one antibody, named $\mathrm{M} 30$, recognized epithelial cells which from their morphological pattern appeared to be apoptotic. That observation led to the identification of a caspase cleavage site in CK18 and to the characterization of a neo-epitope that is exposed only during apoptosis. In the course of this study, it became evident that a positive staining reaction with $\mathrm{M} 30$ can be regarded as an early visible event in the apoptotic cascade.

\section{Materials and methods}

\section{* M30 MONOCLONAL ANTIBODY}

The monoclonal antibody $\mathrm{M} 30$ was produced by immunization of $\mathrm{Balb} / \mathrm{c}$ mice with two purified CK18 fragments from cell culture medium ${ }^{11}$ from the human colonic carcinoma cell 
line WiDr CCL218 and subsequent spleen cell hybridization with mouse myeloma cells (P3x63-Ag 8.653, kindly supplied by Professor G. Köhler, the Max Planck Institute of Immunology, Freiburg, Germany).

\section{* IMMUNOHISTOCHEMISTRY}

Epithelial WiDr CCL218 cells, grown on cover slips for three days and fixed in methanol at $20^{\circ} \mathrm{C}$ overnight and in 96 per cent ethanol, were incubated with $\mathrm{M} 30$ at $0.5 \mu \mathrm{g} \mathrm{gG} / \mathrm{ml}$ for 30 $\mathrm{min}$ at room temperature (RT), followed by peroxidase (PO) labeled antimouse Ig (DAKO A/S, Glostrup, Denmark). The human squamous non-small cell lung cancer cell line MR65, a kind gift of Dr Gropp (Philips Universitäts Klinik, Marburg, Germany), was grown on coverslips for 1 day and fixed for $5 \mathrm{~min}$ in methanol at $-20^{\circ} \mathrm{C}$. The cells were incubated with $\mathrm{M} 30$ for $1 \mathrm{hr}$ at room temperature, followed by fluorescein isothiocyanate (FITC)-conjugated $\mathrm{F}\left(\mathrm{ab}^{\prime}\right)_{2}$ fragments of rabbit anti-mouse IgG (F313; DAKO A/S; diluted 1:10). The cells were counterstained with $5 \mu \mathrm{g} / \mathrm{ml}$ propidium iodide (PI; Calbiochem, La Jolla, CA, USA) and RNAse (1 mg/ml; SERVA, Heidelberg, Germany) for $7 \mathrm{~min}$. The cells were finally embedded in glycerol/DABCO/PI (9:1 glycerol, 1 part $0.2 \mathrm{M}$ TRIS/HCl $(\mathrm{pH} 8.0), 2$ per cent DABCO, 5 $\mu \mathrm{g} / \mathrm{ml} \mathrm{PI}, 0.02$ per cent $\mathrm{NaN}_{3}$ ).

Five $\mu \mathrm{m}$ thick sections from formalin-fixed, paraffin-embedded colonic adenocarcinoma were incubated, after antigen retrieval by microwave heating for 15 minutes at $700 \mathrm{~W}$ in citrate buffer $(0.2 \mathrm{M}, \mathrm{pH} 6.0)$, with $\mathrm{M} 30$ at $1 \mu \mathrm{g} \mathrm{IgG/ml} \mathrm{for} 1 \mathrm{hr}$ at room temperature. Biotinylated rabbit anti-mouse Ig (DAKO) was followed by PO-labeled streptavidin (DAKO). The PO labels were visualised with aminoethylcarbazole (AEC; Sigma, St. Louis, MO, USA) in $0.002 \% \mathrm{H}_{2} \mathrm{O}_{2}$, resulting in a red precipitate. Nuclear counterstain was done with haematoxylin. To see whether or not M30 immunoreactivity depended on hyperphosphorylation of cytokeratins, phorbol ester-treated cells (see below) were doublestained with RCK106 (IgG subtype), a monoclonal antibody against $\mathrm{CK} 18^{13}$, and $\mathrm{M} 30$ ( $\mathrm{IgG}_{2 \mathrm{~b}}$ subtype). After fixation in methanol at $-20^{\circ} \mathrm{C}$ for $5 \mathrm{~min}$, the cells were incubated with both primary antibodies for $1 \mathrm{hr}$ at room temperature. Antibody binding was visualized using FITC-conjugated rabbit anti-mouse $\mathrm{IgG}_{1}$ and TxRed-conjugated rabbit anti-mouse $\operatorname{IgG}_{2 \mathrm{~b}}$ (Southern Biotechnology Associates, Birmingham, AL, USA).

To compare the reaction pattern of M30 with that of other apoptosis markers, such as the specific exposure of PS on the outer leaflet of the cell membrane ${ }^{6}$, MR65 cells were subjected to etoposide (Calbiochem, La Jolla, CA, USA) for various time spans to induce apoptosis.

Labelling of the cells was done with biotinylated annexin V prior to harvesting. After fixation in methanol at $-20^{\circ} \mathrm{C}$ for $5 \mathrm{~min}$, the binding of annexin $\mathrm{V}$ to PS at the outer membrane surface was visualized with the aid of FITC-labeled streptavidin (DAKO). These fixed cell samples were incubated with the M30 monoclonal antibody. Antibody binding was visualised using TxRed conjugated rabbit anti-mouse IgG2b (Southern Biotechnology Associates, Birmingham, AL, USA). Visualisation of DNA strand-breaks was done by the incorporation of DIG-11-UTP and detection with FITC-conjugated Fab fragments of sheep anti-digoxygenin (Boehringer Mannheim, Germany) in a TUNEL assay as described before? . DNA was counterstained using DAPI ( $5 \mu \mathrm{g} / \mathrm{ml}$; Sigma). Confocal images were recorded using a Bio-Rad MR600 confocal scanning laser microscope equipped with an air cooled argon/krypton mixed gas laser. DAPI fluorescence was recorded in a non-confocal mode. 


\section{* INDUCTION OF CYTOKERATIN AGGREGATION}

In order to evaluate M30 reactivity under non-apoptotic conditions, cytokeratin-aggregation was induced in MR65 cells by means of the phorbol-ester methods of Tölle et al ${ }^{16}$. Briefly, phorbol 12-myristate 13-acetate was added to conditioned culture medium at a final concentration of $0.15 \mu \mathrm{m}$ for $1 \mathrm{hr}$ at $37^{\circ} \mathrm{C}$. The cells were then washed twice with PBS of $0^{\circ} \mathrm{C}$ and incubated with PBS for $1 \mathrm{hr}$ at $0^{\circ} \mathrm{C}$.

Alternatively, induction of cytokeratin aggregation was induced by treatment of cells with a hypotonic buffer $(90 \mathrm{mM} \mathrm{NaCl}, 3 \mathrm{mM} \mathrm{KCl}$ and $10 \mathrm{mM}$ TRIS/HCl pH= 7.3$)$ for $1 \mathrm{hr}$ at $0^{\circ} \mathrm{C}$.

\section{* FLOW CYTOMETRY}

M30 reactivity was compared with the results of the annexin V and TUNEL assays in trivariate M30/annexin V/DNA and M30/TUNEL/DNA flow cytometric (FCM) analyses.

For flow cytometric analysis of M30 monoclonal antibody binding, DNA content and TUNEL reactivity, MR65 cells were induced to undergo apoptosis using etoposide. Cells were harvested by trypsinization and fixed for $5 \mathrm{~min}$ in methanol at $-20^{\circ} \mathrm{C}$. Visualisation of DNA strand-breaks using the TUNEL assay and M 30 monoclonal antibody binding was performed on suspended cells as described above. Cellular DNA was counterstained using propidium iodide $(5 \mu \mathrm{g} / \mathrm{ml}$, Calbiochem, La Jolla, CA, USA) in PBS $(\mathrm{pH} 7.4)$ containing $0.1 \mathrm{mg} / \mathrm{ml}$ RNAse (SERVA). Analyses were performed using a FACsort flow cytometer equipped with an air cooled argon ion laser (Becton Dickinson, Sunnyvale, USA).

\section{* Western BLOTTING}

MR65 cells treated with etoposide for $4.5 \mathrm{~h}$ or $7 \mathrm{hr}$ were harvested by scraping and subjected to SDS/polyacrylamide gel electrophorese (PAGE) followed by Western blotting. Antibodies against poly(ADP-ribose) polymerase (anti-PARP, BioMol, Plymouth Meeting, PA, USA) and CK18 (RCK106) were applied in parallel with M30. Monoclonal antibody binding was visualized using peroxidase conjugated rabbit anti-mouse $\operatorname{Ig}$ (DAKO) with subsequent detection using enhanced chemiluminescence (ECL-kit, Amersham LifeSciences, Essex, UK).

\section{* M30 EPITOPE MAPPING}

In order to chemically characterize the M30 epitope, the antibody was tested against a number of synthetic oligopeptides, synthesized using the multipin approach utilizing polyethylene supports derivatized wih an acid handle ${ }^{17}$. Peptides representing both the $\mathrm{N}$ - and $\mathrm{C}$-terminal truncation series of the optimally reacting sequence EDFNLGDALD and other sequences were synthesized. They were capped with biotin using the tetra-peptide linker sequence SGSG- or -SGSB-, and attached to streptavidin-coated plates in the enzyme-linked immunosorbent assay. Reactivity between the monoclonal antibody M30 and the chemically synthesized oligopeptides was investigated in the following manner. Peptides were dissolved at $10 \mathrm{mg} / \mathrm{ml}$ in $1: 1$ acetonitrile:water and diluted with $10 \mathrm{mM}$ PBS, $0.1 \%$ Tween 20 , to a concentration of $0.01 \mathrm{mg} / \mathrm{ml}$. The ELISA was carried out in wells of a streptavidin-coated NUNC Maxisorb plate (GIBCO/BRL, Täby, Sweden).. After blocking of non-specific absorpt- 


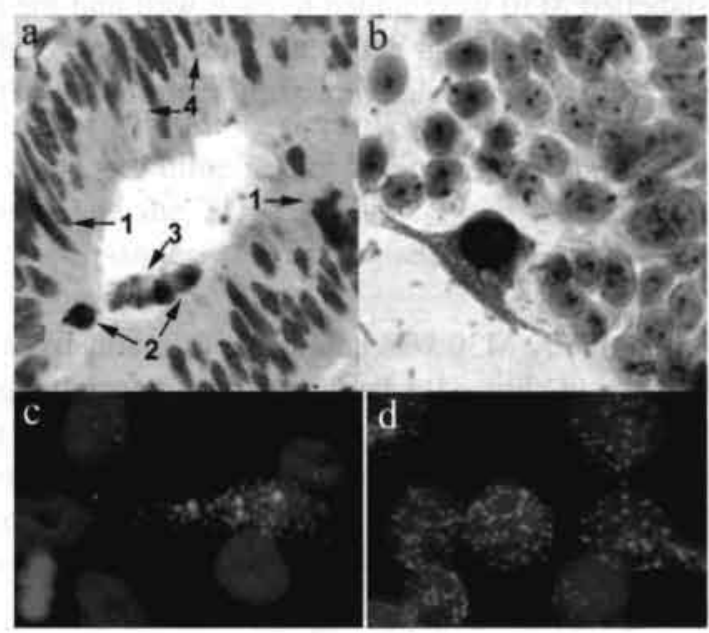

Figure 1 Formalin fixed, paraffin embedded colonic carcinoma (a) cultured colonic carcinoma cells (WiDR CCL218) (b) and cultured non-small cell lung cancer cells (MR65) (c) exposed to the M30 monoclonal antibody. x 250. (a) Cells with apoptotic morphology such as chromatin condensation (arrow 1) nuclear fragmentation (arrow 2) and detachment of cytoplasm from environment (arrows 1,2) showed cytoplasmic staining for M30. Progressively degraded cells (arrow 3) are negative for $\mathrm{M} 30$ as are the tumour cells with intact morphology ( $\mathrm{a}$ and b). In addition, some cells show granular cytoplasmic staining (arrow 4). (b) M30 reactive WiDR cells showing a filamentous staining pattern. (c) M30-reactive MR65 cells showing the distinct nuclear apoptotic morphology, i.e. chromatin condensation and fragmentation. Note that cells with intact nuclear morphology, including the metaphase cell, are devoid of $\mathrm{M} 30$ staining. (d) Triple labelling of CK18 (green), M30 (red) and DNA (blue) of MR65 cells after phorbol -ester treatment. Note that the cytokeratin aggregates are devoid of M30 immunoreactivity.
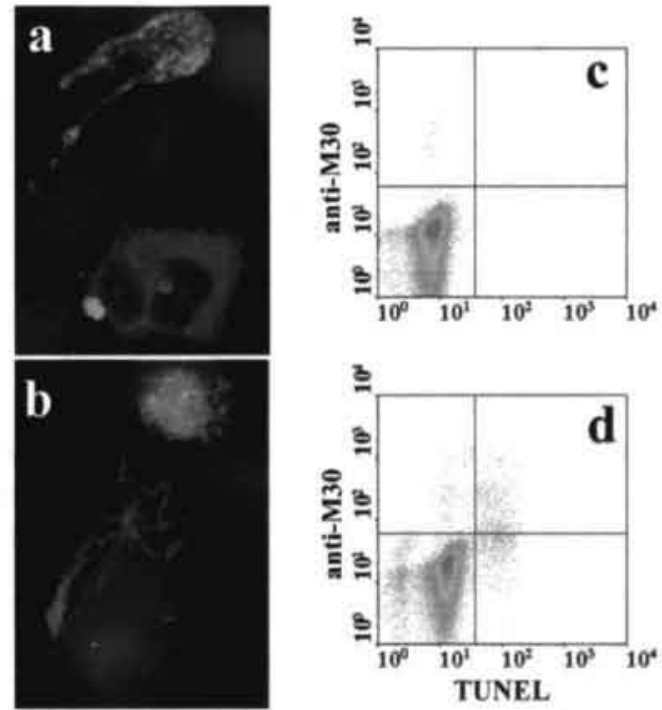

Figure 2. Triple staining of MR65 cells with M30 monoclonal antibody (red), DNA (blue) and annexin V (a) or TUNEL (b) method (green) after apoptosis induction with etoposide. Cells were analysed by confocal scanning laser microscopy and are represented as linear projections of stacks of confocal images. (c,d) Flow cytometric analysis of triple labeled MR65 cells. Cytograms of TUNEL reactivity ( $\mathrm{x}$-axis) and M30 binding $(\mathrm{y}$-axis) at $2.75 \mathrm{~h}(\mathrm{c})$ and $5.75 \mathrm{~h}(\mathrm{~d})$ after induction of apoptosis with etoposide. 
ion, $100 \mu \mathrm{l}$ aliquots of PO-labelled M30 were added to each well and the plate was incubated for $1 \mathrm{hr}$ at $22^{\circ} \mathrm{C}$ with shaking. After washing, substrate was added to each well and readings were made at $405 / 492 \mathrm{~nm}$ with a Titertek Multiscan instrument (Titertek Instr Corp., Huntsville, AL, USA).

\section{Results}

When the mouse monoclonal antibody $\mathrm{M} 30$ was applied to formalin-fixed paraffin-embedded colonic adenocarcinoma, this tissue showed a variety of immunostaining reactions (fig 1a). Cells with apoptotic morphology, showing chromatin condensation (arrow 1), nuclear fragmentation (arrow 2), and detachment of cytoplasm from the environment (arrows 1,2), showed cytoplasmic staining for M30. Progressively degraded cells (arrow 3) were negative for M30, as were the tumor cells with intact morphology ( $\mathrm{a}$ and $\mathrm{b}$ ). In addition, some cells showed granular cytoplasmic staining (arrow 4).

In WiDR CCL218 cell cultures, a few cells without apparent apoptotic nuclear features, but apparently beginning to detach from the surface of the glass slides showed filamentous cytoplasmic staining with M30 (Fig. 1b).

Taken together with the fact that M30 was raised against CK18 fragments and that it shows a filamentous staining pattern next to a granular pattern in several other types of epithelial cells, this indicated to us that the antibody recognizes an epitope on CK18 intermediate filaments.

In exponentially growing non-small-cell lung carcinoma MR65 cells, a small fraction of the cells $( \pm 5 \%)$ showed a bright, cytoplasmic, granular-like immunofluorescence reactivity pattern with M30, together with features characteristic of apoptotic nuclei, i.e. chromatin condensation and nuclear disintegration (Fig. 1c). Double labelling of the same cell with M30 and RCK106, directed against another epitope of the CK18 antibody ${ }^{13}$, revealed a complete overlap of the immunoreactivity pattern of both antibodies only in apoptotic cells. However, all mitotic cells, in which spontaneous aggregation of cytokeratin filaments is sometimes observed with the RCK106 antibody, were devoid of immunoreactivity with the M30 monoclonal antibody (Fig. 1c). Even after induction of cytokeratin aggregation by phorbolester-induced hyperphosphorylation of cytokeratins, aggregated structures remained negative for M30, as shown after double labelling of cells with RCK106 and M30 (Fig. 1d).

A large fraction of the apoptotic cells containing M30-positivity showed membrane affinity for annexin V (Fig. 2a). In the majority of these cells, M30 immunoreactivity was seen in aggregated cytokeratin structures, but in a small fraction a filamentous pattern was seen. A few annexin V-negative cells with a filamentous M30 staining pattern were also found. The nuclei of the latter cells showed no or only minor apoptotic features, while other MR65 cells which showed membraneous staining for annexin V, but no staining for M30, exhibited complete nuclear disintegration in almost all cases.

Similarly, M30 immunoreactivity preceded TUNEL reactivity (Fig. 2b). The small fraction of cells showing a filamentous staining pattern with M30 were TUNEL-negative, while the majority of the cells with an aggregated M30 immunoreactivity pattern were TUNEL-positive. Again a fraction of cells were M30-negative and TUNEL-positive, and these cells exhibited complete nuclear disintegration in almost all cases. 
In the multivariate flow cytometric analyses of MR65 cell culture, the fraction of M30-positive cells increased dramatically, from $2 \%$ to $24 \%$ within $6 \mathrm{hr}$, after induction of apoptosis with etoposide. With time, the fraction of annexin V-reactive cells and of TUNEL-positive cells also increased (Figs. 2c,d). Positivity for any of the three parameters was accompanied by a decrease in DNA content, resulting in a hypodiploid cell population ${ }^{4}$. M30 reactivity preceded that of the Annexin V and the TUNEL assay. Upon extended exposure to etoposide, M30 reactivity decreased, while annexin $\mathrm{V}$ binding and TUNEL assay reactivity still remained.

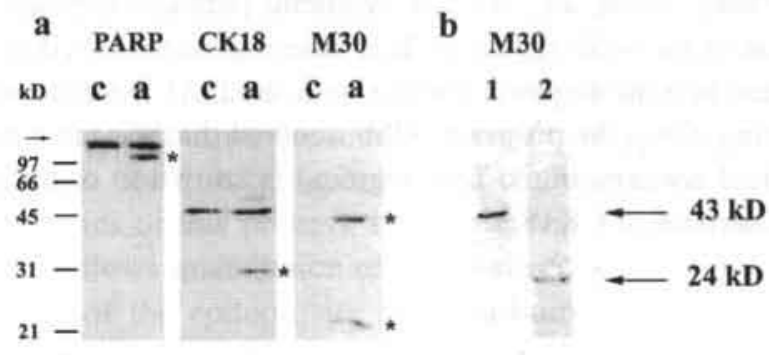

c

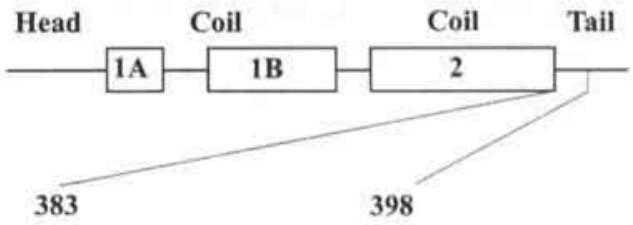

LEDGEDFNLGDALDSS Reactivity

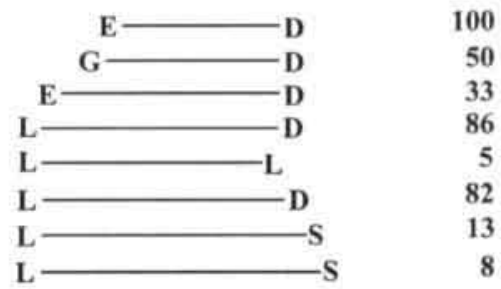

Figure 3 M30 immunoblotting (a,b) and epitope mapping (c ). (a) Immunoblotting of control (c ) and apoptotic (a) MR65 cell cultures. Apoptosis was induced using etoposide. Immunoblots were stained with anti-PARP (lanes 1), RCK106 (lanes 2) and M30 monoclonal antibody (lanes 3). (b) Immunoblotting of MR65 cell lysates of adherent (lane 1) and detached (lane 2) MR65 cells treated with etoposide for $4.5 \mathrm{hr}$. Immunoblots were stained with the M 30 monoclonal antibody. In lane 1, a $43 \mathrm{kD}$ fragment slightly smaller than the intact CK18 protein $(45 \mathrm{kD})$ is immunoreactive with $\mathrm{M} 30$. In lane 2, CK18 is further degraded into a $24 \mathrm{kD}$ fragment. (c) M30 epitope localization in CK18.

The results obtained by immunocytochemistry were confirmed by Western blotting (Fig. 3). Cell lysates of exponentially growing cells were negative for M30, while in cell lysates from apoptotic cultures, two M30-reactive protein bands of approximately 40 and $24 \mathrm{kD}$ were immunostained. The appearance of M30-reactive fragments paralleled PARP-cleavage and the appearance of an additional $30 \mathrm{kD}$ cytokeratin fragment detected with RCK106 (Fig. 3a).

When late apoptotic cells (i.e. detached cells) were separated from early apoptotic cells (i.e. cells firmly attached to the culture flask), it was shown that the $40 \mathrm{kD}$ fragment was 
preferentially found in the early apoptotic fraction, while the $24 \mathrm{kD}$ fragment was mainly detected in the late apoptotic cells (Fig. 3b). To map the M30 epitope in CK18, the molecule was screened for caspase cleavage sites, using several consensus motifs including the DALD$\mathrm{X}$ recognition signal ${ }^{3,12}$. The latter was found to be unique to CK18 and is thus not detected in other cytokeratins known in the protein data banks. Chemical synthesis of peptides corresponding to the relevant cytokeratin segments and to two other potential caspasecleavage motifs of CK18 revealed that only the CK18-unique segment was indeed M30reactive. Further tests, using an array of synthetic peptides corresponding to elongated and truncated segments of the M30-reactive CK18 segment, established that the maximal reactivity was limited to a ten-residue segment ending with the DALD-structure (Fig. 3c). Furthermore, molecular modelling using the program $\mathrm{ICM}^{1}$ showed that the most reactive peptide segments could form $\pi$ helical conormations. This segment is known to occur at the transition of coil 2 to the C-terminal domain of CK18. ${ }^{9}$

\section{Discussion}

Our results establish that early in apoptosis CK1 18 is cleaved by caspases, resulting in exposure of an epitope that only then becomes detectable with M30. Combined cytochemical and morphological data link the M30 reactivity to early apoptotic events. Although initially observed with WiDr cells and described here for MR65 cells, the early expression of M30 reactivity in the apoptotic cascade takes place in all cells of epithelial origin that were examined but are not described here in detail, such as epithelia of the gastrointestinal tract, liver, female genital tract, urinary tract, and respiratory tract. Several other cell lines of epithelial origin, including those derived from a mammary carcinoma (MCF7), a cervical carcinoma (HeLa) and a urinary bladder carcinoma (T24), showed staining patterns identical to those described for MR65 (unpublished observations) .

CK18 has a widespread distribution and is largely co-expressed with CK8 in practically all simple, non-stratified, ductal and pseudostratified epithelia, while these two cytokeratins are also the first ones to appear in embryonic development. CK18 has been reported to be produced in small amounts also in fibroblasts and other non-epithelial cells ${ }^{14}$. Recently, CK filaments have been observed to aggregate rapidly in apoptotic cells ${ }^{2,15}$ and immunoreactivity with several CK antibodies finally disappears completely. ${ }^{5}$ This aggregation is mediated by hyperphosphorylation of the cytokeratins. ${ }^{10}$ Apart from hyperphosphorylation, CK18 is cleaved by a caspase, liberating a neo-epitope which is specifically recognized by the M30 monoclonal antibody. We found that this specific proteolytic cleavage is an event taking place before disruption of membrane asymmetry and DNA strand-breaks occur. From the results of Western blotting, it can be suggested that soon after triggering of the apoptotic cascade, a novel peptide C-terminus is proteolytically liberated on CK18 by cleavage of the peptide bond 396-397. Both the modelling and the previous domain assignments show that the DALD ${ }^{396 \pm} \mathrm{S}$ site, now defined as the end of the 10-residue epitope, is at a site compatible with caspase accessibility and cleavage (Fig. 3c). CK18 cleavage products with characteristics similar to those found in this study have been suggested to be derived through activity of caspase 3 or $7^{2}$, but further caspases with this specificity are not excluded. In the late apoptotic cells, the cleavage process has progressed further and results in a smaller CK18 fragment of 
approximately $20 \mathrm{kDa}$ in which the M30-epitope is still retained. In the early phase of apoptosis, CK18 is still retained in a filamentous network, despite caspase cleavage. CK18 forms aggregates only when the process of apoptosis progresses, possibly as a result of phosphorylation of the protein; in the end phase, when the cells become necrotic, the M30 epitope is lost.

In conclusion, antibody M30 defines an epitope on CK18 that is independent of phosphorylation events and permits the detection of early phases of apoptosis before other methods such as the TUNEL assay or the annexin V assay. The reactivity of the epitope in formalin-fixed, paraffin-embedded sections makes M30 a valuable tool in routine pathology to study the impact of apoptosis, both in retrospect and prospectively. Because the exposure of the M30 neo-epitope seems to occur in the initial phase of the apoptotic cascade, it may be used in studies on the dynamics of this process, by monitoring the induction or inhibition of apoptosis. The M30 marker allows quantitation of apoptotic epithelial cells at the level of the cytoskeleton. The definition of the epitope site shows a correlation with known molecular properties of caspase cleavage sites. This provides a molecular basis for an early apoptotic event and offers the possibility of therapeutic intervention when apoptotic processes are out of balance.

\section{Acknowledgments}

Part of this work was supported by EC grant BIO 4-CT97-2123. 


\section{References}

1. Abagyan. R, Totrov M. Biased probability Monte Carlo conformational searches and electrostatic calculations for peptides and proteins. J Mol Biol 1994; 235: 983-1002

2. Caulin, C., Salvesen, G. S. \& Oshima, R. G. Caspase cleavage of keratin 18 and reorganization of intermediate filaments during epithelial cell apoptosis. J Cell Biol 1997; 22: 379-394

3. Cohen GM. Caspases: the executioners of apoptosis. Biochem J 1997; 326: 1-16

4. Darzynkiewicz, Z., Juan, G., Li, X., Gorczyca, W., Murakami, T. \& Traganos, F. Cytometry in cell necrobiology: analysis of apoptosis and accidental cell death (necrosis). Cytometry 1997; 27: 1-20

5. Engeland M, van, Kuijpers HJM, Ramaekers FCS, Reutelingsperger CP, Schutte B. Plasma membrane alterations and cytoskeletal changes in apoptosis. Exp Cell Res 1997; 235: 421-430

6. Engeland, M, van, Nieland, L. J. W., Ramaekers, F. C. S., Schutte, B. \& Reutelingsperger, C. P. M. Annexin Vaffinity assay: a review on an apoptosis detection system based on phosphatidyl-serine exposure. Cytometry 1998; 31 : $1-9$

7. Gorczyca, W., Gong, J. \& Darzynkiewicz, Z. Detection of DNA strand breaks in individual apoptotic cells by the in situ terminal deoxynucleotidyl transferase and nick translation assays. Cancer Res 1993; 53: 1945-1951

8. Kroemer, G., Petit, P., Zanzani, N., Vayssiere, J.-L. \& Mignotte, B. The biochemistry of programmed cell death. FASEB J 1995; 9: 1277-1287

9. Leube, R. E., Bosch, F. X., Romano, V., Zimbelmann, R., Höfler, H. \& Franke, W. W. Cytokeratin expression in simple epithelia. III. Detection of mRNAs encoding human cytokeratins no. 8 and 18 in normal and tumor cells by hybridization with cDNA sequences in vitro and in situ. Differentiation 1986; 33: 69-85

10. Liao J, Ku NO, Omary MB. Stress, apoptosis and mitosis induce phosphorylation of human keratin 8 at ser- 73 in tissues and cultured cells. J Biol Chem 1997: 272: 17 565- 17573

11. Rydlander, L., Ziegler, E., Bergman, T., Schöberl, E., Steiner, G., Bergman, A.-C., Zetterberg, A., Marberger, M., Björklund, P., Skern, T., Einarsson, R. \& Jörnvall, H. Molecular characterization of a tissue-polypeptide-specificantigen epitope and its relationship to human cytokeratin 18. Eur J Biochem 1996;241:309-314

12. Salvesen, G.S. \& Dixit, V.M. Caspases: intracellular signalling by proteolysis. Cell 1997,91, 443-446

13. Schaafsma, H. E., Ramaekers, F. C. S., van Muijen, G., N., P., Lane, B. E., Leigh, I. H., Robben, H., Huijsmans, A., Ooms, E. C. M. \& Ruiter, D. J. Distribution of cytokeratin polypeptides in human transitional cell carcinomas, with special emphasis on changing expression patterns during tumor progression. Am J Pathol 1990; 136: 329-343

14. Schaafsma, H. E. \& Ramaekers, F. C. S. Cytokeratin subtyping in normal and neoplastic epithelium: Basic principles and diagnostic applications. Pathol Ann 1994; 29: 21-62

15. Tinnemans, M. M., Lenders, M. H., Velde, G. P. ten, Ramaekers, F. C. S. \& Schutte, B. Alterations in cytoskeletal and nuclear matrix-associated proteins during apoptosis. Eur J Cell Biol 1995; $68: 35-46$

16. Tölle H-G, Weber K, Osborn M. Keratin filament disruption in interphase and mitotic cells - how is it induced? Eur J Cell Biol 1986; 43: 35-47

17. Valerio, R. M., Bray, A. M. \& Maeji, N. J. Multiple peptide synthesis on acid-labile handle derivatized polyethylene supports. Int J Peptide Protein Res 1984; 44: 158-165. 


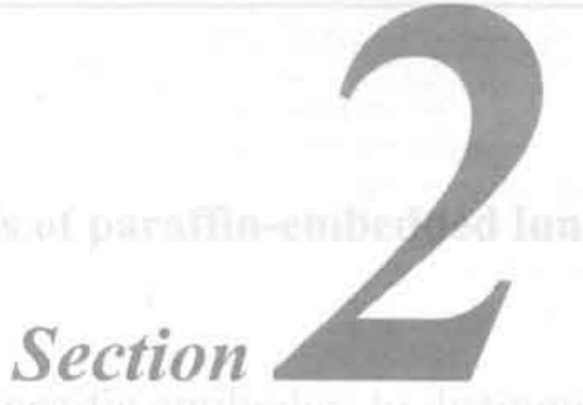

\section{Clinical applications}





\section{Trivariate flow cytometric analysis of paraffin-embedded lung cancer specimens:}

Application of cytokeratin subtype specific antibodies to distinguish between differentiation pathways

M.P.G. LEERS ${ }^{1}$, P.H.M.H. THEUNISSEN ${ }^{1}$, JOH. KOUDSTAAL', B. SCHUTTE ${ }^{2}$, F. C.S. RAMAEKERS ${ }^{2}$

'Department of Pathology, De WeVer Hospital, HeERlen and ${ }^{2}$ DePartment of Molecular Cell BIology \& GENETICS, UNIVERSITY OF LIMBURG, MAASTRICHT, THE NETHERLANDS

CYTOMETRY 1997; 27: 179-188 


\begin{abstract}
The aim of the present study was to investigate whether trivariate FCM analysis, for the simultaneous detection of two different CK subtypes in combination with DNA content, can be applied to paraffin embedded samples of different types of non- small cell lung cancer in order to evaluate the cell cycle of individual sublines. Single cell suspensions were prepared from $50 \mu \mathrm{m}$ thick paraffin sections of 22 lung carcinomas by pepsin digestion and immunostained with CK-antibodies which were chosen to distinguish glandular differentiation (adenocarcinomas) and squamous differentiation. There was a good correlation between the immunocytochemical results of the different CK antibodies in tissue sections and in the corresponding single cell suspensions. Gating for CK-positivity revealed a higher S-phase fraction as compared to the ungated cell population. The tumor cells in adenocarcinoma cases were specifically recognized by CK7 antibodies, while well-differentiated squamous cell carcinomas were specifically stained for CK14 and/or CK17. In poorly differentiated squamous cell carcinomas simultaneous expression of CK7 and CK17 was detected in a subpopulation of the tumor cells, next to cells positive for CK7 or CK17 alone. The trivariate FCM analysis allowed the separate estimation of ploidy status and cell cycle parameters in the three different cell populations of these, apparently (phenotypically) heterogeneous, malignancies.
\end{abstract}

\title{
Introduction
}

Flow cytometric ( $\mathrm{FCM}$ ) analysis of solid tumors is frequently hampered by the admixture with a variable amount of stromal and inflammatory cells as well as with normal epithelium. By applying the bivariate FCM analysis, combining cytokeratin (CK) immunocytochemistry and quantitative DNA staining procedures, it is possible to study selectively epithelial (cancer) cells $^{6,29}$. In a recent study ${ }^{11}$ we applied a bivariate DNA analysis to paraffin embedded tissue samples of colorectal carcinomas by using a modification of the enzymatic digestion technique of Hedley et $\mathrm{al}^{8}$. It was shown that CK-filaments are retained in the epithelial cells after enzymatic digestion of paraffin embedded tissue ${ }^{11}$. Recently, Nylander et al ${ }^{15}$ described a similar method for applying dual parameter analysis to paraffin embedded samples of squamous cell carcinomas of the head and neck region.

In the former study ${ }^{11}$ we have shown that the reactivity of a broad panel of antibodies is retained after pepsin digestion. The aim of the present study was to investigate the feasibility of a trivariate FCM analysis of paraffin embedded lung cancers, some of which were heterogeneous in nature, combining glandular and squamous differentiation. Since different types of epithelia and carcinomas contain different types of CKs, the use of monoclonal antibodies to CKs allows the immunohistochemical distinction between different epithelial lineages ${ }^{19}$. From previous studies it is known that squamous cell carcinomas commonly express CKs 14,15 and $17^{19,23,24}$ while adenocarcinomas are mainly characterized by CKs 7 , $8,18,19$ or $20^{17,19}$. For example, extensive CK7 expression in pulmonary adenocarcinomas can distinguish these tumors from squamous cell carcinomas ${ }^{12}$. Combining two different monoclonal $\mathrm{CK}$ antibodies, specific for either glandular or squamous differentiation, with 
DNA staining in one assay would allow a detailed analysis of tumor cell subpopulations in these heterogeneous lung cancers. Such a method, although it might not immediately improve the diagnosis of lung cancer, may be of general value for the study of processes involved in tumorigenesis, or tumor progression, particularly the accumulation of genomic changes resulting in tumor cell heterogeneity.

\section{Materials and methods}

\section{* TUMOR SAMPLES}

Fresh tissue specimens of 22 pulmonary carcinomas were divided in two. One portion was snap frozen in liquid nitrogen and stored at $-70^{\circ} \mathrm{C}$, and another portion of the same tumor was immediately fixed in $10 \%$ buffered formalin for exactly 24 hrs and routinely processed for paraffin embedding. All lung tumors were classified and graded independently by two pathologists (PT and JK) according to the WHO classification ${ }^{28}$.

\section{* IMMUNOHISTOCHEMISTRY OF TISSUE SECTIONS}

The panel of monoclonal antibodies (MoAbs) used in this study, and recognizing individual cytokeratins (CKs), is described in Table 1. In order to evaluate the cytokeratin expression in the individual tumors, consecutive $5 \mu \mathrm{m}$ thick paraffin embedded sections were stained with the different cytokeratin-antibodies as described before " peroxidase complex method and a 3,3'-diaminobenzidine(DAB)- $0.002 \% \mathrm{H}_{2} \mathrm{O}_{2}$-solution (Sigma Chemical Co., St. Louis, MO) to visualize the immune reaction. Sections were counterstained with Harris' hematoxylin, dehydrated, cleared in xylene and finally embedded in Entellan. Simultaneous expression of different CK-subtypes was histomorphologically examined by an immunoenzyme double staining procedure of tissue sections. These double staining experiments were performed by two successive, indirect immunochemical techniques. After incubation with the first MoAb for $1 \mathrm{hr}$ at room temperature (RT), this binding was labeled with an indirect streptavidin-biotin- HorseRadishPeroxidase (HRP) method using biotinylated sheep-anti-mouse Ig serum (1:400, Amersham Int., Buckinghamshire UK; $1 \mathrm{hr}$ at RT) as bridging antibody, followed by preformed streptavidinbiotin-HRP-complex using an strepABC staining kit (DAKO; 1:1:100; $1 \mathrm{hr}$ at RT). Bound $\mathrm{HRP}$ was made visible with a 3-amino-9-ethylcarbazole (Sigma)- $0.002 \mathrm{H}_{2} \mathrm{O}_{2}$ solution ? After washing thoroughly with phosphate buffered saline (PBS), the sections were incubated with the second primary mouse $\mathrm{MoAb}$ ( $1 \mathrm{hr}$ at RT). Subsequently, incubation with rabbit antimouse Ig (DAKO; 1:50 for $1 \mathrm{hr}$ at RT) and monoclonal alkaline phosphatase anti-alkaline phosphatase (APAAP; DAKO, 1:50 for $1 \mathrm{hr}$ at RT) was performed after appropriate washing. Alkaline phosphate (AP) activity was detected according to Hoeltke et al 9; the incubation medium contained naphtol-AS-MX-phosphate $(0.2 \mathrm{mg} / \mathrm{ml})$ as substrate and Fast Blue BB (1 $\mathrm{mg} / \mathrm{ml})$ as azodye $\left(30 \mathrm{~min}, 37^{\circ} \mathrm{C}\right)$. To inhibit the endogenous AP activity, levamisole was added to the incubation medium to a final concentration of $1 \mathrm{mM}$. 

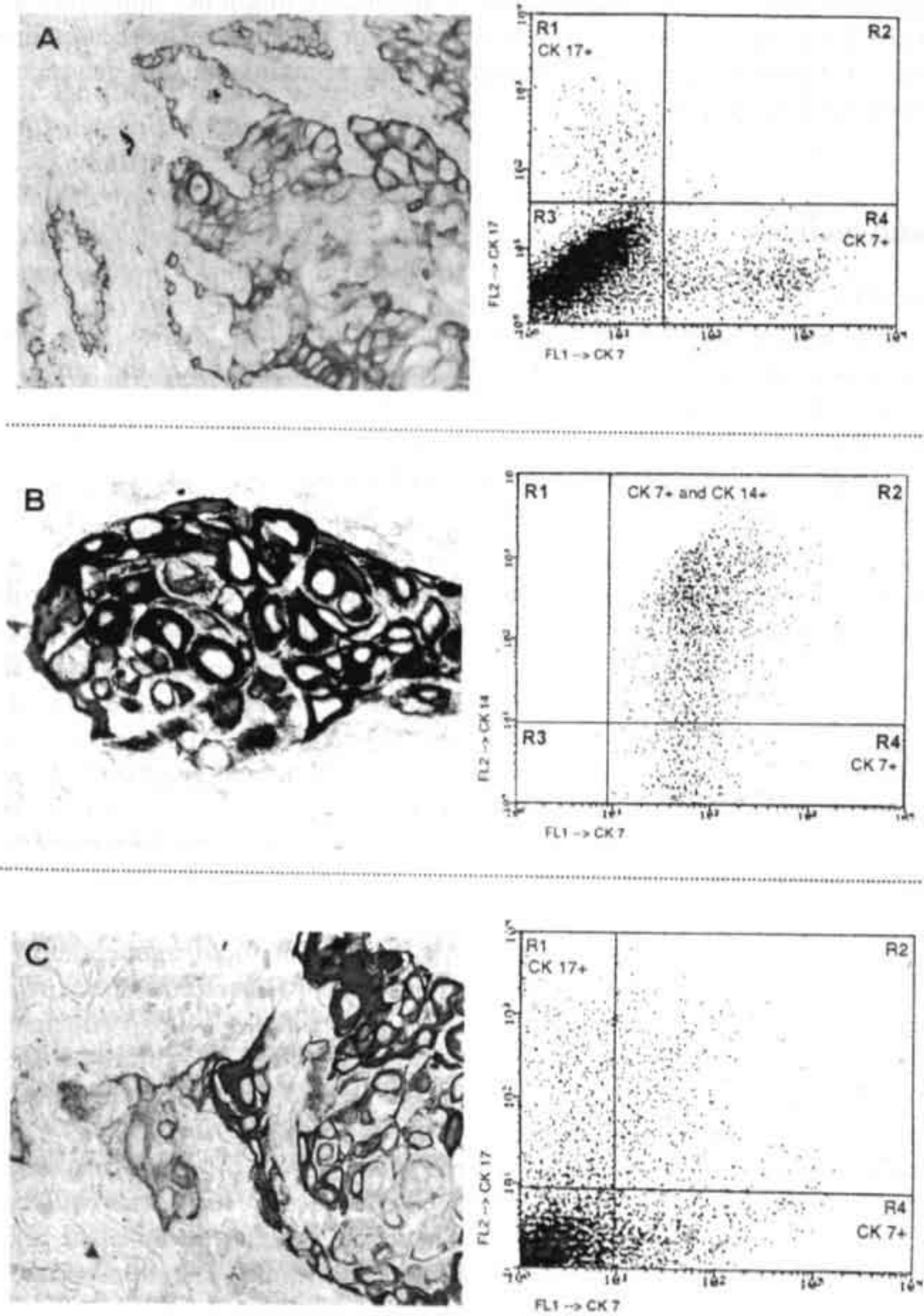

Figure 1.

Illustrations of three-parameter analyses of three different pulmonary squamous cell carcinomas, showing the immunoenzyme double staining of a paraffin section of the tumor (left), the dotplot showing the FITC-signal of CK7-labeled cells and the RPE-signal of the CK14- or CK17-labeled cells, on the X-and Y-axis, respectively (middle) and the corresponding DNA-histograms (right; ungated and after gating for immunoreactivity with the different CK-subtypes) The solid lines in the dotplots denote the tresholds for immunoreactivity as based on the negative controls. A. CASE 1. Welldifferentiated squamous cell carcinoma of the lung, showing immunohistologically an admixture of normal CK7-positive type II pneumocytes (blue) and CK17-positive tumor cells (red). The DNA-histograms, generated from the CK 7-positive normal cells turned out to be diploid, while the DNA-histogram of the CK17-positive cells only shows an aneuploid peak (DI=1.55; corresponding to the tumor cells). 

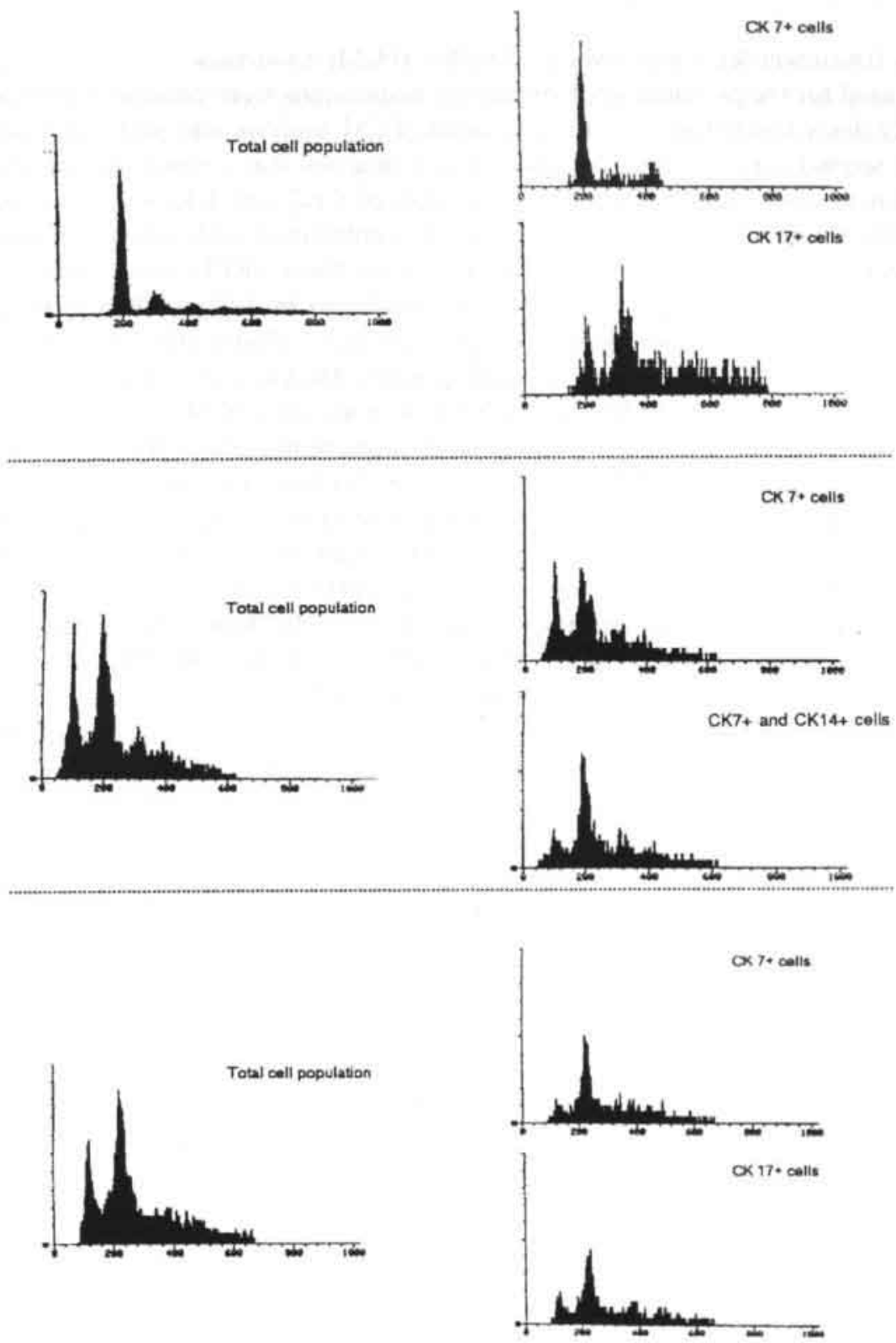

\section{Figure 1. (Continued)}

B. CASE 26. Poorly-differentiated squamous cell carcinoma. The epithelial cells show immunohistochemically a coexpression for $\mathrm{CK}_{7}$ (red) and CK14 (blue). Threeparameter FCM-analysis produces a dotplot in which the majority of the cells are positive for CK7 as well as CK14. This is also seen in the DNA-histograms of this cell fraction, which show a substantial enrichment of the aneuploid fraction $(\mathrm{DI}=1.83)$.

C. CASE 16. Poorly-differentiated squamous cell carcinoma. Immunohistochemically, three different populations can be distinguished: one population which is exclusively positive for CK7 (red), one population which shows immunoreactivity for only CK17 (blue) and finally a population with co-expression for these two CK-subtypes (reddish-blue). After threeparameter analysis these three different populations can also be distinguished in the dotplot. However, gating for the various combinations of CK expression does not shown an increase in the relative frequency of aneuploid cells in the corresponding DNA-histograms . 


\section{* IMMUNOCYTOCHEMISTRY FOR FLOW CYTOMETRIC (FCM) ANALYSIS}

The method used for the preparation of single cell suspensions from paraffin embedded tissue has been fully described before ${ }^{11,21}$. First, bivariate FCM analysis was performed on 22 lung tumors. In a second series a three-parameter FCM analysis was carried out on 10 selected cases, i.e. tumors showing simultaneous expression of CK7 and CK14 and/or CK17. The indirect immunofluorescence technique was used in combination with primary mouse MoAbs and fluorescein isothiocyanate (FITC) or r-phycoerythrin (RPE)-conjugated secondary immunoreagents. Approximately $10^{6}$ cells were incubated in $100 \mu \mathrm{l}$ TRIS buffered saline (TBS; $\mathrm{pH}=7.4$ ) containing appropriately diluted primary MoAb (for characteristics and references see table 1). For triple staining both primary MoAbs were added simultaneously, i.e. anti-CK7 (a $\mathrm{IgG}_{1}$-mouse $\mathrm{MoAb}$ ) in combination with anti-CK14 or -CK17 (both $\operatorname{IgG}_{2}$ mouse MoAbs). After an overnight incubation at room temperature, the cells were rinsed twice in TBS. In the bivariate FCM analysis antibody-binding was visualized by incubating the cell pellet, resuspended in $100 \mu \mathrm{l}$ TBS, with $6 \mu \mathrm{l}$ of FITC-conjugated goat-anti-mouse Ig (Fab-fragment; DAKO A/S, Glostrup, Denmark; final dilution 1:20). For triple staining, both secondary antibodies were added simultaneously (i.e. FITC-conjugated goat-anti-mouse IgG $_{1}$ (1:30) and RPE-conjugated goat-anti-mouse $\operatorname{IgG}_{2}(1: 30)$, both from Southern Biotechnology Association, Inc. Birmingham, USA). After incubation in the dark for $1 \frac{1}{2} \mathrm{hr}$ at room temperature, samples were rinsed twice in TBS and the cells were finally counterstained with propidium iodide (PI; $5 \mu \mathrm{g} / \mathrm{ml}$, Sigma, St. Louis, MO) in PBS containing $0.1 \mathrm{mg} / \mathrm{ml}$ RNAse A (Serva, Heidelberg, Germany). The samples were allowed to stand for 15 minutes on ice in the dark before FCM analysis. For three parameter FCM analysis the PI concentration was decreased to $1 \mu \mathrm{g} / \mathrm{ml}^{21}$. Ten $\mu \mathrm{l}$ of the cell suspension was examined by fluorescence microscopy to assess the efficiency of immunostaining and the degree of cell clumping. In all samples analysed, doublets comprised less than $5 \%$ of the cells studied. As a negative control for CK staining, a cell suspension prepared from a normal lymph node, fixed for $24 \mathrm{hr}$ in $10 \%$ neutral buffered formalin and embedded in paraffin, was used. As a negative control for background staining, lung cancer cells were stained using the mouse anti-BrdU MoAb (clone IIBS) ${ }^{20}$. To control for bleed through of the different fluorochrome signals, single FITC, RPE or PI stained samples were FCM analysed. To control for cross reactivity of the Ig-isotypespecific secondary antibodies, the appropriate primary antibody was omitted from the immunocytochemical double-staining procedure. For all three-parameter FCM analyses no cross reactivity of the secondary antibodies was observed (data not shown).

\section{* FLOW CYTOMETRY}

All samples were analysed using a FACScan flow cytometer (Becton \& Dickinson,San Jose, CA, USA). Fluorochromes were excited at $488 \mathrm{~nm}$ by an Argon laser. FITC-fluorescence was detected through a $515-545 \mathrm{~nm}$ BP filter, RPE-fluorescence through a $572-588 \mathrm{~nm}$ BP filter and PI-fluorescence through a $600 \mathrm{~nm}$ LP filter. FITC and RPE signals were recorded as logarithmic amplified data, while the PI signals were recorded as linear amplified data. For bivariate FITC/PI analysis no compensation was used. In the tricolor analyses, cross talk between the different channels was compensated using the following settings: $448 \mathrm{~V}, 405 \mathrm{~V}$ and $437 \mathrm{~V}$ on photomultiplier tubes for FL1 (FITC), FL2 (RPE) and FL3 (PI), respectively. Compensation for (FL1-\%FL2), (FL2-\%FL1), (FL2-\%FL3) and (FL3-\%FL2), was 1.1\%, $38.5 \%, 41.8 \%$ and $8.3 \%$, respectively. Cell cycle analysis was performed with CellFit software (Becton \& Dickinson). The S-phase fraction (SPF) was calculated from histograms 
of ungated cells and from cells gated for CK-positivity. For both DNA-diploid as well as DNA-aneuploid tumors the polynomial model ${ }^{18}$ was used. SPF calculation was only performed when the CK-positive gate comprised at least 4000 events. A tumor sample was designated positive for a specific CK subtype when the percentage of CK-positive cells (designated as CK-positive cell fraction) comprised more than $5 \%$ of the whole cell suspension.

Table 1 Antibody characteristics, references and sources

\begin{tabular}{|c|c|c|c|c|c|}
\hline Antibody & $\mathrm{CK}$-antigen ${ }^{2}$ & $\begin{array}{l}\text { Dilution } \\
\text { On tissue } \\
\text { section }\end{array}$ & $\begin{array}{c}\text { In cell } \\
\text { Suspension }\end{array}$ & Ref. & Source \\
\hline OVTL- $12 / 30$ & 7 & $1: 30$ & $1: 33$ & 12 & DAKO A/S, Glostrup, Denmark \\
\hline CAM 5.2 & 8 & $1: 75$ & $1: 33$ & 27 & Becton Dickinson, San Jose, CA, USA \\
\hline LLO02 & 14 & $1: 50$ & $1: 20$ & 25 & BioGenex, San Ramon, CA, USA \\
\hline E3 & 17 & $1: 15$ & $1: 10$ & 22 & DAKO A/S, Glostrup, Denmark \\
\hline RCK 108 & 19 & $1: 30$ & $1: 33$ & 21 & DAKO A/S, Glostrup, Denmark \\
\hline IT-K, 20.8 & 20 & $1: 20$ & $1: 10$ & 10 & DAKO A/S, Glostrup, Denmark \\
\hline
\end{tabular}

$\mathrm{a}=$ no, according to Moll-catalogue ${ }^{13}$

** dilution for suspensions prepared from fresh as well as paraffin embedded tissue

\section{Results}

When $50 \mu \mathrm{m}$ thick deparaffinized and rehydrated tumor tissue sections were digested by pepsin for 80 minutes $\left(37^{\circ} \mathrm{C}\right)$, a sufficient number of cells could be obtained to perform bivariate FCM analyses. When examined in the fluorescence microscope it became evident that these isolated cells had retained enough cytoskeletal remnants around the nucleus to allow detection of several CK- subtypes ${ }^{\text {II }}$.

* Cytokeratin SUBTyPE IMMUNOREACTIVITY: PARAFFin TISSUE SECTIONS VS. CELL SUSPENSIONS (TABLE 2)

First of all, we examined the extent of agreement between the immunochemical results with the MoAbs in tissue sections and in the cell suspensions of the corresponding paraffin embedded tumors. A broad panel of MoAbs against CKs was tested (see table 1). The series of lung carcinomas consisted of 22 cases: 10 squamous cell carcinomas, 5 adenocarcinomas, 5 large cell undifferentiated carcinomas and 2 adenosquamous carcinomas. The specificity of the different CK-MoAbs in the lung cancer cell suspensions is summarized in table 2. The results obtained in tissue sections correlated well with the FCM results obtained from cell suspensions for all six antibodies.

Squamous cell carcinoma: An extensive CK-positive cell fraction for CK14, CK17 and CK19 was present in the majority of the samples, both tissue sections and cell suspensions. CK7expression was observed in about half of the squamous cell carcinoma, mainly in the poorly differentiated cases. This phenomenon was also observed for the expression of CK8 (in tissue sections as well as in cell suspensions). In cell suspensions the greatest CK-positive cell fraction was obtained with the CK17- and CK19-antibodies. 
Adenocarcinoma: These tumors were in all cases positive for CK7, CK8 and CK19, both in tissue sections as well as in cell suspensions. CK17 was found in a single case, with only a small CK positive cell fraction.

Large cell anaplastic carcinoma: These tumors showed in almost all cases clear expression for CKs 7, 8, 14 and 19, both in tissue sections as well as in cell suspensions. Three out of five samples were positive for CK17. CK7-immunoreactivity was found in the largest tumor cell fraction of these cell suspensions.

Adenosquamous carcinoma: The two cases of adenosquamous carcinoma investigated, were both positive for CK7, CK8 and CK19. One tumor was also positive for CK14 and CK17. This simultaneous expression was also seen in the cell suspension of that tumor. Again, the greatest CK positive cell fraction was obtained with the CK7-antibody.

Table 2 Overall immunochemical and FCM results of the 22 cases of formalin fixed, paraffin embedded carcinomas used to prepare cell suspensions

\begin{tabular}{|c|c|c|c|c|c|c|c|}
\hline & UG & CK $7^{2}$ & CK8 & CK14 & CK17 & CK19 & CK20 \\
\hline \multicolumn{8}{|l|}{ Squamous cell carcinoma $(n=10)$} \\
\hline \multicolumn{8}{|l|}{ No of positive cases: } \\
\hline In tissue section & - & $5 / 10^{b}$ & $5 / 10$ & $9 / 10$ & $9 / 10$ & $8 / 10$ & $0 / 10$ \\
\hline In cell suspension & - & $6 / 10$ & $6 / 10$ & $8 / 10$ & $9 / 10$ & $9 / 10$ & $0 / 10$ \\
\hline Mean CK pos cell fraction ( $\%)$ & - & 14 & 14 & 15 & 24 & 25 & 4 \\
\hline Mean SPF $(\%)$ & $13(6-20)^{6}$ & $21(19-23)$ & $32(24-40)$ & $32(22-42)$ & $27(20-34)$ & $28(22-34)$ & - \\
\hline \multicolumn{8}{|l|}{ Adenocarcinoma $(\mathrm{n}=5)$} \\
\hline \multicolumn{8}{|l|}{ No. of positive cases: } \\
\hline In tissue section & - & $4 / 5$ & $5 / 5$ & $0 / 5$ & $1 / 5$ & $5 / 5$ & $0 / 5$ \\
\hline In cell suspension & - & $5 / 5$ & $4 / 5$ & $0 / 5$ & $1 / 5$ & $5 / 5$ & $0 / 5$ \\
\hline Mean CK pos cell fraction ( $\%)$ & - & 38 & 18 & 2 & 12 & 28 & 3 \\
\hline Mean SPF $(\%)$ & $11(7-15)$ & $23(14-32)$ & $33(29-37)$ & - & 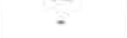 & $30(22-38)$ & - \\
\hline \multicolumn{8}{|l|}{ Large cell carcinoma $(n=5)$} \\
\hline \multicolumn{8}{|l|}{ No. of positive cases: } \\
\hline In tissue section & . & $5 / 5$ & $5 / 5$ & $4 / 5$ & $3 / 5$ & $5 / 5$ & $0 / 5$ \\
\hline In cell suspension & - & $5 / 5$ & $4 / 5$ & $4 / 5$ & $3 / 5$ & $5 / 5$ & $0 / 5$ \\
\hline Mean CK pos cell fraction ( $\%)$ & - & 26 & 9 & 6 & 21 & 15 & 2 \\
\hline Mean SPF (\%) & $15(9-21)$ & $22(16-28)$ & $31(22-40)$ & $28(18-38)$ & $24(22-26)$ & $28(22-34)$ & 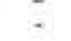 \\
\hline \multicolumn{8}{|l|}{ Adenosquamous carcinoma $(n=2)$} \\
\hline \multicolumn{8}{|l|}{ No, of positive cases: } \\
\hline In tissue section & - & $2 / 2$ & $2 / 2$ & $1 / 2$ & $1 / 2$ & $2 / 2$ & $0 / 2$ \\
\hline In eell suspension & - & $2 / 2$ & $2 / 2$ & $2 / 2$ & $2 / 2$ & $2 / 2$ & $0 / 2$ \\
\hline Mean CK pos cell fraction (\%) & - & 29 & 13 & 8 & 14 & 18 & 4 \\
\hline Mean SPF (\%) & 11 & 25 & 28 & 25 & 27 & 29 & . \\
\hline
\end{tabular}

$\mathrm{a}=$ Cytokeratin-subtype; $\mathrm{b}=$ number of positive cases over number of cases tested; $\mathrm{c}=$ Between brackets: range of individual cases; $\mathrm{SPF}=\mathrm{S}$-phase fraction; $\mathrm{UG}=$ ungated, no label

* BIVARIATE CK/DNA ANALYSIS: PARAFFIN EMBEDDED VS. FROZEN TUMOR SAMPLES OF THE SAME CASES (TABLE 3 )

The next step was to examine the feasibility of the CK/DNA bivariate FCM analysis in cell suspensions derived from paraffin blocks. For this purpose, the squamous cell carcinomas $(n=10)$ and adenocarcinomas $(n=5)$ were analysed. From all these 15 cases both freshly, frozen tissue as well as formalin fixed, paraffin embedded tissue samples were available. The results with the MoAbs against CKs 7, 8,19 and 20 are comparable to those of our previous study on colorectal carcinomas " and can be summarized as follows (see Table 3 ): 
- the staining results in tissue sections with the different antibodies correlated well with the staining results of the cell suspension prepared for flow cytometry

- the immunoreactivity patterns for the different CKs were similar when suspensions from paraffin and frozen tissues of the individual cases were compared;

- the CK-positive fractions were considerably higher in cell suspensions derived from fresh frozen tissue as compared to the corresponding paraffin sample;

- a good correlation was found between the DNA-index obtained from cell suspensions prepared from either fresh frozen or formalin fixed, paraffin embedded tumor samples;

- the SPF obtained from paraffin embedded samples was comparable to that of fresh frozen tissue samples;

- in comparison to the ungated cell population, the SPF values were in general increased when this analysis was performed after gating for CK-positivity, both in paraffin and fresh frozen tissue samples. This phenomenon was more pronounced for paraffin embedded samples.

\section{* Cell CyCle analysis of CK POSITIVE Cells}

The cell suspensions prepared from the 22 cases of paraffin embedded lung carcinomas were also further examined for cell cycle parameters by FCM (see Table 2). The CV of the $\mathrm{G}_{0} / \mathrm{G}_{1}$ peak of the tumor cells was within acceptable limits ${ }^{22}$ ( mean $\mathrm{CV} \mathrm{G}_{0} / \mathrm{G}_{1}$ peak 3.4-5.3\%) and decreased in the majority of the cases after gating for CK-positivity. For all these cases of lung carcinomas the SPF was increased after selectively analyzing the CK-positive cells (Table 2). Striking differences in SPF were observed when cell fractions gated for the various CK subtypes were compared, suggesting heterogeneity within the tumor tissue.

\section{* ThreE-Parameter FCM RESUlts of parafFin embedded lung carcinomas (TABLE 4)}

To investigate the feasibility of the trivariate FCM protocol for the analysis of heterogeneity of paraffin embedded lung cancer, 10 carcinomas ( 5 squamous cell carcinomas, 3 large cell carcinomas and 2 adenocarcinomas) were selected based on their simultaneous expression patterns in tissue sections of CKs typical for glandular differentiation (CK7, CK8 and CK19) and CKs of squamous differentiation (CK14 or CK17). These 10 carcinoma samples were analysed by three-parameter FCM for DNA content and the combined expression of either CK7 and CK14 or CK7 and CK17.

The 5 carcinomas positive for CK14 comprised 4 squamous cell carcinomas (cases 1, 8, 16 and 26) and 1 adenocarcinoma (case 23) as summarized in Table 4. In cases 1 and 8, the aneuploid cells exclusively express CK14, while the diploid cells were CK7 positive and CK14 negative. Microscopic analysis of the tissue section revealed CK7 positivity only in normal type II pneumocytes (see fig 1A). When gating for these CK7 positive cells only a diploid cell population was indeed found. In the other two squamous cell carcinoma samples (cases 16 and 26, Table 4) the CK14 expression patterns were more heterogeneous (Fig. 1B), with aneuploid cells in both the CK7+/CK14- and the CK $7+/$ CK $14+$ compartments as shown after gating. In the CK14 positive adenocarcinoma sample (case 23) the aneuploid fraction was limited to the $\mathrm{CK} 7+/ \mathrm{CK} 14+$ population.

The 9 carcinomas positive for CK17 comprised 5 squamous cell carcinomas (case 1, 8, 16, 19 and 26), 1 adenocarcinoma (case 11) and 3 large cell anaplastic carcinomas (cases 6, 22 and 
21). Again, in cases 1 and 8 the CK7 positive (DNA diploid) cell fraction was negative for CK17 (Fig. 1A). On the contrary, the CK17 positive tumor cells of this case showed a predominant DNA aneuploid stemline. In the other CK 17 positive cases, except for case 21, the CK expression patterns were more heterogeneous, showing aneuploid cells in various CK subpopulations (Fig, 1C).

In some cases a substantial enrichment of the aneuploid fraction could be achieved by gating on various combinations of CK expression patterns (see table 4, cases 1, 8, 23 and 26, and Fig. 1B), while in others the relative frequency of aneuploid cells remained unchanged after gating as compared to the ungated data (fig. 1C).

Table 3 Comparison of bivariate FCM results obtained from suspensions derived from fresh frozen and from paraffin embedded tumor samples $(n=15)$

\begin{tabular}{|c|c|c|c|c|c|}
\hline & UG & CK $7^{2}$ & CK8 & CK19 & CK20 \\
\hline \multicolumn{6}{|c|}{ Squamous cell carcinoma $(n=10)$} \\
\hline \multicolumn{6}{|c|}{ No of positive cases: } \\
\hline Fresh frozen & - & $3 / 10^{b}$ & $6 / 10$ & $9 / 10$ & $0 / 10$ \\
\hline Paraffin & - & $5 / 10$ & $5 / 10$ & $8 / 10$ & $0 / 10$ \\
\hline \multicolumn{6}{|c|}{ Mean CK pos cell fraction (\%) } \\
\hline Fresh frozen & - & 32 & 31 & 39 & 12 \\
\hline Paraffin & - & 14 & 14 & 25 & 4 \\
\hline \multicolumn{6}{|l|}{ Mean SPF (\%) } \\
\hline Fresh frozen & $13(7-19) c$ & $18(9-27)$ & $12(4-20)$ & $21(12-30)$ & - \\
\hline Paraffin & $13(6-20)$ & $21(19-23)$ & $32(24-40)$ & $28(22-34)$ & - \\
\hline \multicolumn{6}{|c|}{ Adenocarcinoma $(n=5)$} \\
\hline \multicolumn{6}{|c|}{ No. of positive cases: } \\
\hline Fresh frozen & - & $5 / 5$ & $5 / 5$ & $5 / 5$ & $0 / 5$ \\
\hline Paraffin & - & $4 / 5$ & $5 / 5$ & $5 / 5$ & $0 / 5$ \\
\hline \multicolumn{6}{|c|}{ Mean CK pos cell fraction (\%) } \\
\hline Fresh frozen & - & 28 & 33 & 41 & 12 \\
\hline Paraffin & - & 38 & 18 & 28 & 2 \\
\hline \multicolumn{6}{|l|}{ Mean SPF (\%) } \\
\hline Fresh frozen & $13(3-23)$ & $17(7-27)$ & $21(16-26)$ & $16(6-26)$ & . \\
\hline Paraffin & $11(7-15)$ & $23(14-32)$ & 33 (29-37) & $30(22-38)$ & - \\
\hline
\end{tabular}

$\mathrm{a}=$ Cytokeratin subtype; $\mathrm{b}=$ number of positive cases over number of cases tested; $\mathrm{c}=$ Between brackets: range of individual cases, $\mathrm{SPF}=\mathrm{S}$-phase fraction; $\mathrm{UG}=$-ungated, no label

Table 4 DNA-index of the different epithelial lineages within one tumor, as defined by their CK expression pattern

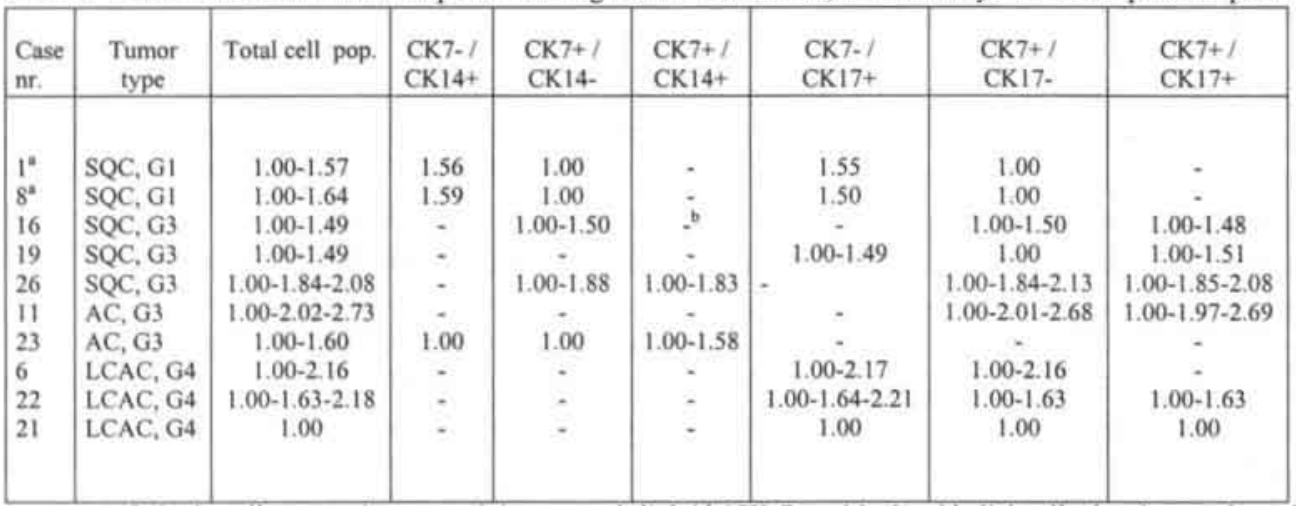

$\mathrm{a}=$ cases of single-cell suspensions containing normal diploid (CK 7-positive) epithelial cells; $\mathrm{b}=$ the number of cells was too small to calculate a reliable DNA-index; $\mathrm{SQC}=$ squamous cell carcinoma; $\mathrm{AC}=$ adenocarcinoma; $\mathrm{LCAC}=$ large cell anaplastic carcinoma; $\mathrm{CK}=$ cytokeratin; $\mathrm{Gl}=$ well-differentiated; $\mathrm{G} 3=$ poorly differentiated; $\mathrm{G} 4=$ undifferentiated 


\section{Discussion}

In a recent study, a method for the bivariate CK/DNA flow cytometric analysis of paraffin embedded samples of colorectal carcinomas was developed ". It became apparent that the nuclei present in the suspensions obtained from the paraffin embedded tissues had retained enough CKs to allow their FCM recognition as epithelial cells. The aim of the present study was to further develop this method in such a way that different lineages of epithelial differentiation, present within a (heterogeneous) tumor sample, could be analysed seperately by FCM. For this purpose we have selected lung cancer cases, known to often present two or more types of differentiation within the same tumor. Based on the findings of our earlier study ${ }^{11}$, we have selected antibodies that give similar results, in particular with respect to the percentage of immunoreactive cells, when comparing paraffin embedded tissue sections and cell suspensions derived from these paraffin blocks. Monoclonal antibodies against cytokeratin 7 can distinguish pulmonary adenocarcinoma ${ }^{17,27}$, while CK14 and CK17 have been associated with squamous differentiation in lung carcinomas ${ }^{27}$.

\section{* BIVARIATE FCM ANALYSIS OF LUNG TUMORS}

The CK expression patterns of the different types of lung carcinomas may show a considerable heterogeneity. First of all, CK7, which is considered to be a marker for glandular differentiation ${ }^{12}$ and to be largely absent in squamous cell carcinomas ${ }^{14}$, was expressed in a part of the tissue sections as well as in the cell suspensions of five out of ten cases of pulmonary squamous cell carcinoma, investigated in this study. In all these five cases it marked poorly differentiated tumors, as described before by Ramaekers et al ${ }^{16}$. In squamous cel carcinomas CK7 expression is apparently related to the degree of differentiation, since well-differentiated and moderately differentiated squamous cell carcinomas were virtually all negative for CK7. Second, the results of the present study show that CK14, considered as a marker of squamous epithelium, is expressed in 4 out of 5 cases of large cell anaplastic carcinomas. It may however well be possible that some lung carcinomas classified as poorly differentiated squamous cell carcinomas would better be classified as large cell anaplastic carcinoma of the lung on the basis of CK-expression patterns. The histological distinction between a poorly differentiated squamous cell carcinoma and a large cell anaplastic carcinoma is often difficult. In general, most of the antibodies used in this study displayed in the cell suspensions an immunoreactivity pattern similar to that found in the tissue sections. In 5 cases however, which were positive in the tissue sections no immunostaining with any of the CK antibodies was detected. This may be due to technical factors, such as tissue processing or extended enzymatic digestion. The CK14-immunopositive fraction in cell suspension was in general small compared to the extended fraction that could be stained for CK14 in the tissue section. Masking of the CK14-epitope in paraffin embedded material might be an explanation for this phenomenon because for immunohistochemistry on tissue sections an antigen-retrieval method (micro-wave heating) is recommended when using antibody LLO02 ${ }^{25}$. In the present study acceptable CV's (3.4 to 5.3\%) were measured for the cell suspensions derived from paraffin embedded tumor samples. In general CV values improved after gating for the CK positive fractions, which can be explained by the elimination of necrotic material and stromal debris ${ }^{4,5}$.

When samples, double labeled for DNA content on the one hand and the different CK subtypes on the other, were submitted to a detailed cell cycle analysis, it was observed that the SPF values increased after gating on CK positive cells. This could be explained by the 
selective elimination of the nonepithelial cells, such as inflammatory- and stromal cells. Furthermore a general tendency was observed for both adenocarcinomas and squamous cell carcinomas to show the highest mean SPF in the cell fractions expressing CK8, characteristic for simple epithelia, compared to cells expressing more lineage-related $\mathrm{CKs}$, such as $\mathrm{CK} 7$ or CK17.

In squamous cell carcinomas a correlation was found between degree of differentiation and SPF in tumor cell fractions expressing CK14 or CK17. In poorly differentiated tumors the cell fractions expressing CK14 or CK17 tend to have a higher SPF than the same fraction in welldifferentiated tumors. In adenocarcinomas such tendency was observed in cell fractions expressing $\mathrm{CK} 7$ or $\mathrm{CK} 8$.

\section{* Three-Parameter fCM analysis of LUNG tUMORS}

The simultaneous expression of CKs of the simple-epithelial-type (CKs 7, 8, 19) and those typical of stratified epithelia (CK14, 17), as seen in 10 out of 22 lung carcinomas examined was also observed before by several authors $1,2,3,27$.

In all the cases that co-expressed these CKs for different epithelial lineages, co-expression marked poorly differentiated lung tumors. Three-parameter FCM revealed that simultaneous expression of CK7 and CK14 (or CK17) in lung tumors is very often due to co-expression of these CKs in most of the tumor cells (7 out of 10 cases; compare fig. 1B). In two cases the differential expression of the two CK-subtypes was due to an admixture of normal diploid pneumocytes, which are positive for CK7. In all the 7 cases described above there were also different cell populations each of which was exclusively expressing one specific CK subtype. In a few cases different clonal stemlines were found within one and the same tumor, all exhibiting a different set of CK-subtypes. This indicates that, within one tumor, mosaics of cells or groups of cells can exist, each expressing a different set of CKs and with a different DNA-index.

In summary, trivariate CK/DNA FCM analysis (simultaneous immunostaining for two different subtype specific CKs as well as DNA) is a technical advance for a reliable cellkinetic analysis of human tumor cell populations. The immunoreactivity for the different CKsubtypes is well preserved in the single cell suspensions prepared from the paraffin embedded tumor samples. Heterogeneous CK-expression can be correlated to different DNA stemlines and also to the cell cycle kinetic parameters of such tumor cell subpopulations. Prospective studies are needed to further evaluate the correlation between degree of differentiation and SPF in tumor cell fractions expressing CK14 or CK17 that was observed in squamous cell carcinomas. It is now also possible to investigate DNA patterns in different epithelial cell lineages (each expressing a different set of CKs) within heterogeneous tumors such as lung carcinomas. The use of formalin fixed, paraffin embedded tumor blocks facilitates retrospective studies. In this study, we have used a standardized fixation protocol. However, a potential pitfall associated with the use of archival histological material is the lack of uniformity in tissue fixation. Thus, further study is necessary to investigate if prolonged or delayed fixation influences the above described results. 


\section{References}

1. Blobel GA, Moll R, Franke WW, Vogt-Moykopf I. Cytokeratins in normal lung and lung carcinomas. 1. Adenocarcinomas, squamous cell carcinoma and cultured cell lines. Virchows Archiv B 1984; 425: 145-155

2. Broers JLV, Klein Rot M, Oostendorp T, Huijsmans A, Wagenaar SS, Wiersma- Van Tilburg AJM, Vooijs GP, Ramaekers FCS. Immunocytochemical detection of lung cancer heterogeneity using antibodies to epithelial, neuronal and neuroendocrine antigens. Cancer Res 1987; 47: 3225-3234

3. Broers JLV, Ramaekers FCS, Klein Rot M, Oostendorp T, Huijsmans A, Muijen GNP van, Wagenaar SS, Vooijs GP. Cytokeratins in different types of lung cancer as monitored by chain-specific monoclonal antibodies. Cancer Res $1988 ; 48: 3221-3229$

4. Crissman JD, Zarbo RJ, Niebylski CD, Corbett T, Weaver D. Flow cytometric DNA analysis of colon adenocarcinomas; a comparative study of preparatory techniques. Mod Pathol 1988; 1: 198-204

5. Crissman JD, Zarbo RJ, Ma CK, Visscher DW. Histopathological parameters and DNA analysis in colorectal adenocarcinomas. Pathol Annual 1989; 24: 103-147

6. Feitz WFJ, Beck HLM, Smeets AWGB, Debruyne FMJ, Vooijs GP, Herman CJ, Ramaekers FCS. Tissue specific markers in flow cytometry of urological cancers: cytokeratins in bladder carcinoma. Int J Cancer 1985; 36: 349-356

7. Graham RC, Lundholm U, Karnovsky MJ. Cytochemical demonstration of peroxidase activity with 3-amino-9ethylcarbazole. J Histochem Cytochem 1965; 13: 150-152

8. Hedley DW, Friedlander ML, Taylor IW, Rugg CA, Musgrove EA. Method for analysis of cellular DNA content of paraffin-embedded pathological material using flow cytometry. J Histochem Cytochem 1983; 31: 1333-1335

9. Hoeltke HJ, Ettl I, Finken M, West S, Kunz W. Multiple nucleic acid labeling and rainbow detection. Anal Biochem 1992; 207: 24-31

10. Lane EB, Alexander CM. Use of keratin antibodies in tumor diagnosis. Semin Cancer Biol 1990; 1: 165-179

11. Leers MPG, Theunissen PHMH, Schutte B, Ramaekers FCS. Bivariate cytokeratin/DNA flow cytometric analysis of paraffin embedded samples of colorectal carcinomas. Cytometry 1995; 21: 101-107

12. Molengraft FJJM van de, Niekerk CC van, Jap PHK, Poels LG. OV-TL 12/30 (keratin 7 antibody) is a marker of glandular differentiation in lung cancer. Histopathology $1993 ; 22: 35-38$

13. Moll R, Löwe A, Laufer J, Franke WW. Cytokeratin 20 in human carcinomas. Am J Pathol 1992; 140: 427-447

14. Niekerk CC van, Jap PHK, Ramaekers FCS, Molengraft van deFJJM, Poels LG. Immunohistochemical demonstration of keratin 7 in routinely fixed paraffin embedded human tissues. J Pathol 1991; 165: 145-152

15. 15. Nylander K, Stenling R, Gustafsson H, Roos G. Application of dual parameter analysis in flow cytometric DNA measurements of paraffin embedded samples. J Oral Pathol Med 1994; 23: 190-192

16. Ramaekers FCS, Van Niekerk CC, Poels LG, Schaafsma HE, Huijsmans A, Robben H, Schaart G, Vooijs GP. Use of monoclonal antibodies to keratin 7 in the differential diagnosis of adenocarcinomas. Am J Pathol 1990, 136: 641-655

17. Ramaekers FCS, Puts J, Moesker O, Kant A, Jap PHK, Vooijs GP. Demonstration of keratin in human adenocarcinomas. Am J Pathol 1983, 111: 213-224

18. Riley MS, Mahin EJ, Ross W: Clinical applications of flow cytometry. Igaku-Shoin, New York. 1993, pp 296-302

19. Schaafsma HE, Ramaekers FCS. Cytokeratin subtyping in normal and neoplastic epithelium: basic principles and diagnostic applications. Pathol Annual 1994; 29: 21-62

20. Schutte B, Reynders MMJ, Bosman FT, Blijham GH. Studies with antibromodeoxyuridine antibodies. II Simultaneous detection of antigen expression and DNA synthesis by in vivo labeling of mouse intestinal mucosa. $\mathrm{J}$ Histochem Cytochem 1987; 35: 371-374

21. Schutte B, Tinnemans MMFJ, Pijpers GFP, Lenders MJH, Ramaekers FCS. Three parameter flow cytometric analysis for simultaneous detection of cytokeratin, proliferation associated antigens and DNA content. Cytometry 1995; 21: $177-186$

22. Shankey VT, Rabinovitch PS, Bagwell B, Bauer KD, Duque RE, Hedley DW, Mayall BH, Wheeles L. Guidelines for implementation of clinical DNA cytometry. Cytometry 1993; 14:472-477

23. Smedts F, Ramaekers FCS, Trojanovsky SM, Pruszczynski M, Link M, Lane B, Leigh I, Schijf C, Vooijs GP. Keratin expression in cervical cancer. Am J Pathol 1992; 141: 497-511

24. Smedts F, Ramaekers FCS, Trojanovsky S, Pruszczynski M, Robben H, Lane B, Leigh 1, Plantema F, Vooijs GP. Basal-cell keratins in cervical reserve cells and a comparison to their expression in cervical intraepithelial neoplasia. Am J Pathol 1992; 140: 601-612

25. Smedts F, Ramaekers FCS, Link M, Lauerova L, Troyanovsky S, Schijf C, Vooijs GP. Detection of keratin subtypes in routinely processed cervical tissue: implications for tumour classification and the study of cervix cancer aetiology. Virchows Archiv 1994; 425: 145-155

26. Trojanovsky SM, Geulstein VI, Tchipysheva TA, Krutovskikh VA, Bannikov GA. Patterns of expression of keratin 17 in human epithelia: dependency on cell position. J Cell Sci 1989; 93: 419-426 
27. Wetzels RHW, Schaafsma HE, Leigh IM, Lane EB, Troyanovsky SM, Wagenaar SS, Vooijs GP, Ramaekers FCS. Laminin and type VII collagen distribution in different types of human lung carcinoma: correlation with expression of keratins 14, 16, 17 and 18. Histopathology 1992; 20: 295-303

28. World Health Organization. The World Health Organization histological typing of lung tumours. 2nd edition. Am J Clin Pathol 1982; 77: 123-136

29. Zarbo RJ, Visscher DW, Crissman JD. Two-color multiparametric method for flow cytometric DNA analysis of carcinomas using staining for cytokeratin and leucocyte common antigen. Anal Quant Cytol Histol 1989; 11: 391-402 


\section{A novel flow cytometric steroid hormone receptor assay for paraffin embedded breast carcinomas:}

An objective quantification of the steroid hormone receptors and direct correlation to ploidy status and proliferative capacity in a single-tube assay

M.P.G. LEERS' ${ }^{1}$, B. SCHUTTE ${ }^{2}$, P.H.M.H. THEUNISSEN', F.C.S RAMAEKERS ${ }^{2}$, M. NAP'

${ }^{1}$ Department of Pathology, atrium medical Centre, Heerlen and ${ }^{2}$ Department of Molecular Cell BIOLOGY \& GENETICS, UNIVERSITY OF MAASTRICHT, THE NETHERLANDS 


\section{Abstract}

Semiquantitative estimation of steroid hormone receptors by immunohistochemistry applied to paraffin sections is common practice in surgical pathology. Flow cytometric (FCM) analysis of estrogen receptor (ER) and progesterone receptor (PR) levels provides a faster and more objective quantitative assay. However, a major problem in such FCM analyses of solid tumor samples is the admixture of tumor cells with normal epithelial, stromal and inflammatory cells. The aim of the underlying study was to investigate the applicability of a recently developed multiparameter flow cytometric methodology for the accurate estimation of the fraction of steroid hormone receptor-positive tumor cells, and to explore whether this multiparameter approach allows the detection of specific, clinically relevant subsets of tumors, based on a combination of ploidy level, steroid hormone receptor status and cell cycle characteristics. For this purpose samples of 42 breast cancer patients, from which also routine immunohistochemistry for ER and PR was available, were analysed. From each case, a cell suspension was prepared from the paraffin block by applying a heating and short pepsin digestion step to $50 \mu \mathrm{m}$ thick sections. These cell suspensions were double-immunostained for cytokeratin to identify the epithelial cells, and ER or PR, while DNA was quantitatively stained with propidium iodide using an optimized protocol. In the entire group of breast tumors the percentages of ER- and PR-positive cells were registrated in the epithelial subfraction, in combination with DNA ploidy and S phase fraction (SPF). A significant correlation was found between the fraction of hormone receptor positive cells as found by the immunohistochemical and FCM procedures. For ER a correlation coefficient of $r=0.87$ was found, and for PR $r=0.62$, both $p<0.0001$. It became clear that all the diploid breast tumors had more than $30 \%$ tumor cells which were positive for ER with a SPF lower than $10 \%$, while aneuploid tumors contained on average a smaller percentage of steroid hormone receptor positive cells, and simultaneously a SPF greater than $10 \%$. Our results show that this multiparameter FCM analysis allows an objective and reproducible quantification of the fraction of steroid hormone receptor positive cells in the relevant epithelial cell compartment in relation to DNA ploidy status and proliferative capacity in a single-tube assay.

\section{Introduction}

The levels of estrogen- and progesteron receptor (ER and PR, respectively), are important parameters to predict short term prognosis and the response to endocrine therapy of breast and endometrium cancer. Therefore, the analysis of steroid hormone receptor content is widely used in the management of these hormone-dependent malignancies ${ }^{2,5,12,14,20,21,23,24,25,31,35}$. The expression of ER and PR can be determined by quantitative assays, such as ligand binding assays and immunochemical assays, by semiquantitative immunohistochemistry or by flow cytometry (FCM $)^{30}$. However, the heterogeneous cell composition of most tumor samples is one of the limiting factors for both quantitative and semiquantitative receptor assays. Multiparameter FCM analysis of cytoplasmic markers (cytokeratin), hormone receptors (ER or PR) and DNA content facilitates the (semi)quantitative measurement of hormone receptors in 
the relevant subpopulation of cells by focussing on the epithelial cells. Furthermore, receptor content can be analysed in relation to DNA ploidy and growth potential, which is reflected by the percentage of tumor cells in the S-phase of the cell cycle ${ }^{10}$. Both DNA ploidy and the Sphase fraction (SPF) have shown to be important prognostic parameters in cancer. However, this approach is mainly limited to prospective studies since fresh, unfixed tissue samples are normally required.

In earlier studies however we showed that formalin fixed, paraffin embedded tissue samples can be processed for multiparameter FCM ${ }^{15-17}$. Recently we modified the method by including a heating step, applied to $50 \mu \mathrm{m}$ thick deparaffinized, rehydrated tissue sections for $2 \mathrm{hr}$ at 80 ${ }^{\circ} \mathrm{C}$ prior to a short and mild pepsin digestion. This leads to improved cell recovery and high resolution DNA histograms ${ }^{18}$. Furthermore, heating of tissue sections resulted in improved results of immunocytochemical staining procedures applied to the cell suspensions due to improved epitope retrieval. In the present study we applied this new multiparameter FCM technique to the quantification of the steroid hormone receptor positive cell fraction in the relevant epithelial cell population from archival material of breast carcinomas. In order to establish optimal conditions for this assay, we analysed the effects of duration of enzymatic digestion and incubation with the primary antibody on immunoreactivity with the different antibodies directed against the steroid hormone receptors, and investigated the intra- and interassay variability. The results of these trivariate FCM analyses were compared to the immunohistochemical analyses on tissue sections of the same paraffin embedded tumor blocks.

\section{Materials and methods}

\section{* BREast CaRcinoma SAMPLes}

Samples from the primary tumors were obtained during surgery from 42 breast cancer patients undergoing either elective mastectomy or lumpectomy. These tumors were diagnosed according to the WHO classification and graded according to Bloom and Richardson '. Tumor stage was assigned according to the TNM classification. The tumors were classified as infiltrating ductal carcinoma $(n=35)$, lobular carcinoma $(n=6)$ and mucinous carcinoma $(n=1)$. The tumor samples were immediately fixed in $4 \%$ buffered formalin for maximally 24 hrs and then routinely processed for paraffin embedding. These paraffin embedded tumor tissues were used for the trivariate FCM analysis in parallel with immunohistochemistry.

\section{* Preparation of Cell suspension}

From each of the routinely processed paraffin embedded tumors, two $50 \mu \mathrm{m}$ thick sections were cut. These were deparaffinized in xylene and rehydrated in a descending ethanol series. The sections were then immersed in cold citrate solution $(2 \mathrm{mg}$ citric acid/ml aqua dest, $\mathrm{pH}=6.0$ ) and placed at $80^{\circ} \mathrm{C}$ in a water bath for $2 \mathrm{hrs}$. After a 15 minutes cooling period at room temperature the sections were rinsed in phosphate buffered saline (PBS; pH 7.4). The sections were digested for 10 minutes at $37^{\circ} \mathrm{C}$ in a solution of $1 \mathrm{mg} / \mathrm{ml}$ pepsin (Sigma, St. Louis, MO) in $0.1 \mathrm{~N} \mathrm{HCl}$. The sample was then filtered through a $50 \mu \mathrm{m}$ mesh nylon filter. 
The cell suspension was centrifugated at $400 \mathrm{xg}$ and the pellet was resuspended in PBS, supplemented with $1 \%$ bovine serum albumin (BSA; Sigma; BSA/PBS-buffer).

For the study of antibody binding kinetics two different breast tumors were selected and cell suspensions prepared as described above. To study the effect of duration of pepsin digestion on immunoreactivity in the single cells, cell suspensions of these two tumors were incubated for different time periods with the pepsin solution (i.e. 5, 10, 20, 30 minutes).

To study the effect of incubation time with the primary antibody on signal intensity, single cells were incubated for different time periods with the primary antibodies (i.e. 1, 3, 16 and 40 hrs) at room temperature.

To evaluate the reproducibility of the FCM assay, i.e. the intra- and interassay variability, five $50 \mu \mathrm{m}$ thick consecutive paraffin sections of 5 different breast tumors were split into two parts. One part of each tumor sample was analysed for cytokeratin-, ER- and PRimmunoreactivity within one assay, while the other part was analysed in five separate assays.

Table 1 Characteristics of primary antibodies used in this study

\begin{tabular}{|c|l|c|l|c|l|l|}
\hline Antigen & Antibody & $\begin{array}{c}\text { Ig } \\
\text { Sub }\end{array}$ & $\begin{array}{c}\text { Tissue } \\
\text { section }\end{array}$ & $\begin{array}{c}\text { cell } \\
\text { suspension }\end{array}$ & Ref. & Source \\
\hline Cytokeratin & Rabbit & - & $1: 500$ & $1: 500$ & 28 & DAKO A/S, Glostrup, Denmark \\
Mycobacterium & Rabbit & - & $1: 800$ & $1: 800$ & 34 & DAKO A/S, Glostrup, Denmark \\
ER & ID5 & $\mathrm{IgG}_{1}$ & $1: 100$ & $1: 20$ & 26 & DAKO A/S, Glostrup, Denmark \\
PR & $1 \mathrm{A6}$ & $\mathrm{IgG}_{1}$ & $1: 100$ & $1: 20$ & 13 & DAKO A/S, Glostrup, Denmark \\
BrdU & IIB5 & $\mathrm{IgG1}$ & & $1: 50$ & 29 & Eurodiagnostica, Arnhem, NL \\
\hline
\end{tabular}

\section{* MUltiparameter Flow CyTOMETRY}

The double indirect fluorochrome labeled antibody technique with fluoresceine isothyocyanate (FITC)- and r-phycoerythreïn (RPE)- conjugated secondary step reagents was applied in the multiparameter FCM analyses. The characteristics and sources of the primary antibodies used are summarized in table 1 . The single cell suspension was aliquoted into $100 \mu \mathrm{l}$ samples. To each sample two primary antibodies appropriately diluted were added simultaneously, i.e. the polyclonal cytokeratin antiserum in combination with a monoclonal antibody to one of the steroid hormone receptors (ER or PR). After overnight incubation at room temperature the samples were rinsed twice in PBS. Binding of primary antibodies was detected by incubating the cell pellet simultaneously with two secondary antibodies, i.e. goat-anti-mouse-Ig-FITC (DAKO A/S, Glostrup, Denmark, diluted 1:10) and goat-anti-rabbit-Ig-RPE (Boehringer Mannheim, NL, diluted 1:12). After incubation for $1 \frac{1}{2} \mathrm{hr}$ at room temperature, the samples were rinsed twice in PBS and finally the DNA was stained with propidium iodide (PI; $1.0 \mu \mathrm{g}$ $\mathrm{PI} / \mathrm{ml}$, Sigma) in PBS containing $0.1 \mathrm{mg} / \mathrm{ml}$ RNAse (Serva, Heidelberg, Germany). The samples were allowed to stand for 15 minutes on ice in the dark before FCM analysis. As negative controls for background staining, a cell suspension was simultaneously incubated with mouse monoclonal anti-BrdU (clone IIB5, diluted 1:50; as a control for the mouse primary antibodies) and with a polyclonal antiserum directed against bovin mycobacterium (DAKO A/S, diluted 1:800; as a control for the rabbit primary antiserum).

All samples were analysed using a FACScan flow cytometer (Becton Dickinson, San Jose, CA, USA). Cells were excited with a single $488 \mathrm{~nm}$ Argon laser. FITC fluorescence was 
detected through a $515-545 \mathrm{~nm}$ BP filter, RPE-fluorescence through a $572-588 \mathrm{~nm}$ BP filter and propidium iodide (PI)-fluorescence through a $572-588 \mathrm{~nm}$ BP filter. Electronic gating was used to exclude doublets and cellular debris. At least 20,000 events were collected for each sample. FITC- and RPE-signals were recorded as logarithmic amplified data, while the PIsignals were recorded as linear amplified data. The following settings were used: $407 \mathrm{~V}, 329$ $\mathrm{V}$ and $354 \mathrm{~V}$ on photomultiplier tubes for FL1 (FITC), FL2 (PE) and FL3 (PI), respectively. Compensation for (FL1-\%FL2), (FL2-\%FL1), (FL2-\%FL3) and (FL3-\%FL2) was 0.9\%, $39.8 \%, 41.8 \%$ and $8.3 \%$, respectively. Data analysis was performed using Lysys II software (Becton Dickinson). For cell cycle analysis Modfit LT2.0 (Verity Software House, Inc. Maine, USA) was used. The following data were collected:

1) the DNA-index of the tumor cells and the $\mathrm{CV}$ of the first $\mathrm{G}_{0} / \mathrm{G}_{1}$ peak; 2) the S-phase fraction (SPF); 3) the percentage of ER- or PR-positive cells; and 4) the relative fluorescence intensity (RFI) of the hormone receptor signal in the cytokeratin-positive fraction of the tumor. The number of hormone receptor positive cells was determined in the cytokeratin-positive fraction by an arbitrary threshold setting allowing $5 \%$ of positive counts in the negative control. Concerning the SPF, tumors were divided into three categories: tumors with a low SPF (less than $10 \%$ ), tumors with an intermediate SPF (10-25\%) and tumors with a high SPF (more than 25\%). The RFI was calculated as the ratio of the mean fluorescence signal of the cytokeratin positive cell population of the sample as compared to that of the negative control.

\section{* STEROID HORMONE RECEPTOR IMMUNOHISTOCHEMISTRY ON PARAFFIN SECTIONS}

In parallel to steroid hormone receptor-staining in suspension, consecutive sections $4 \mu \mathrm{m}$ thick were cut from the same paraffin embedded blocks. They were mounted on APES-coated slides and air-dried overnight at $37^{\circ} \mathrm{C}$. For immunostaining the sections were deparaffinized in xylene and rehydrated in a descending ethanol series. Endogeneous peroxidase activity was blocked by immersion for 10 minutes in $3 \%$ hydrogen peroxide in methanol, after which the slides were rinsed in phosphate buffered saline ( $\mathrm{PBS} ; \mathrm{pH}=7.2-7.4$ ). The slides were placed in a $0.1 \mathrm{M}$ citrate buffer $(\mathrm{pH}=6.0)$ and boiled for 10 minutes in a microwave oven at $750 \mathrm{~W}$. After preïncubation with $1 \%$ bovine serum albumin (Sigma)/PBS for 10 minutes, the same monoclonal antibodies directed against the ER and PR, were applied at the appropriate dilution (Table 1) overnight at room temperature (RT). As a negative control, sections were incubated with anti-BrdU. Tissue sections of an ER and PR positive human mammary carcinoma served as a positive control. Next to this, the intraductal epithelial glands served as an internal positive control. After washing in PBS, the secondary antibody (biotin-labelled goat antimouse-Ig; 1:400 diluted; DAKO A/S) was applied for 45 minutes at room temperature. After washing in PBS, these slides were incubated with streptavidin conjugated with horseradish peroxidase (1:600; DAKO A/S). After washing in PBS, peroxidase-activity was detected with 3,3 -diaminobenzidine/0.002\% $\quad \mathrm{H}_{2} \mathrm{O}_{2}$-solution (Sigma). Finally, the sections were counterstained with Harris' haematoxylin, dehydrated, cleared in xylene and finally mounted in Entellan. To minimalize the effect of factors which influence the staining intensity, all sections were stained within one run. The intensity and distribution of the specific staining reaction for ER and $P R$ in the breast carcinoma samples were evaluated independently by two observers. Immunostaining in less than $10 \%$ of the tumor cells was categorized as 0 , staining in $10-30 \%$ of tumor cells as 1 , staining in $30-60 \%$ of the tumor cells as 2 and staining in more 
than $60 \%$ of the tumor cells as 3 . The staining intensity was categorized 0,1 and 2 (negativeweak, moderate and strong, respectively). The total immunostaining score consisted of the product of the outcome in both categories, resulting in a minimum score of 0 and a maximum of 6 .
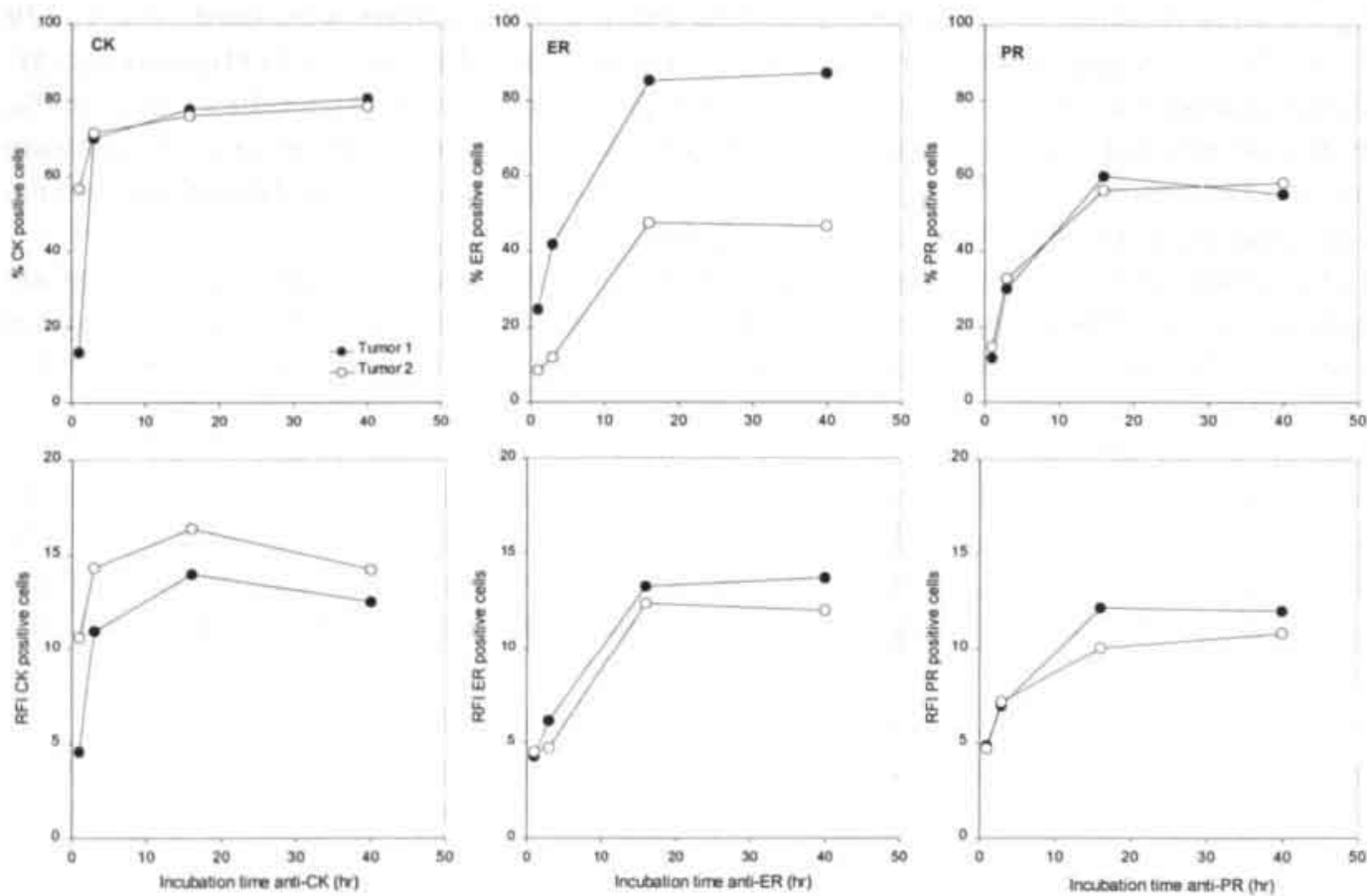

Figure 1 Effect incubation time on primary antibody binding (cytokeratin, ER and PR) as determined by the percentage of positive cells (a.) as well as the relative fluorescence intensity (b.) of the immunoreactive cells. An optimal staining as determined by saturation is achieved after an incubation time of $16 \mathrm{hr}$.

\section{Results}

\section{* METHODOLOGICAL IMPROVEMENTS}

Heating of dewaxed and rehydrated $50 \mu \mathrm{m}$ thick tissue sections for $2 \mathrm{hr}$ at $80^{\circ} \mathrm{C}$ in a citrate solution, followed by a mild pepsin digestion of $15 \mathrm{~min}$ at $37^{\circ} \mathrm{C}$ resulted in a high cell yield with little debris and little cell clusters. As observed by immunofluorescence microscopy, the recovered cells showed an intact nuclear morphology, and ER and PR immunoreactivity appeared to be localized in the nuclei. Furthermore, the cells had retained enough cytoskeletal remnants to allow detection of epithelial cells on the basis of anti-cytokeratin immunofluorescence.

In a pilot series it was noticed that the hormone receptor-positive cells showed a stronger immunofluorescence reaction after overnight incubation with the antibodies directed against ER and PR as compared to a short incubation of $1 \mathrm{hr}$ at room temperature. When the kinetics of antibody binding were investigated in more detail, optimal binding for all antibodies used was seen after approximately $16 \mathrm{hr}$ incubation at room temperature (Fig. 1). 
To investigate whether proteolytic digestion interfered with the semiquantitative measurement of hormone receptor content, single cell suspensions were treated with pepsin for an additional time period. As depicted in figure 2 prolonged proteolytic treatment influenced the levels of hormone receptor content as measured by ER or PR immunoassays, as well as for cytokeratin. A digestion step longer than 15 minutes resulted in a rapid decrease in immunoreactivity.

To determine the reproducibility of the FCM assay, i.e. the intra- and interassay variability, five intact consecutive sections of five different tumor samples were split into two parts. One part was analysed for CK-, ER- and PR-immunoreactivity within one assay, while the other part was analysed in five separate assays. Figure 3 shows that both the intra- and interassay variability is less than $6 \%$.
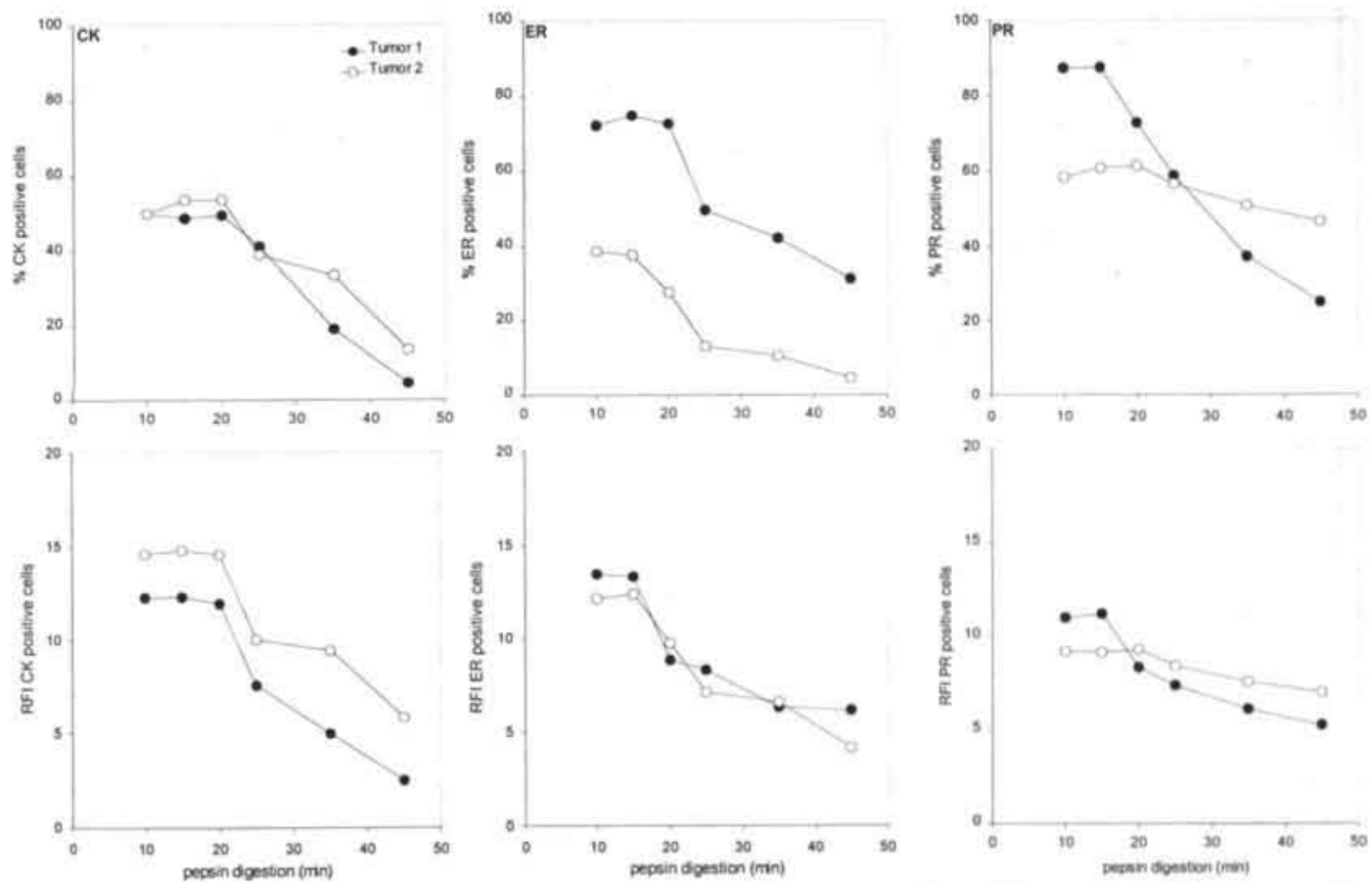

Figure 2 Effect of proteolytic digestion on immunoreactivity for cytokeratin, ER and PR. A proteolytic treatment for longer than 15 minutes results in a rapid decline of all antibodies in the number of positive cells as well as the staining intensity as indicated by the RFI.

\section{* trivariate FCM analysis of breast CANCERs: Comparison with} IMMUNOHISTOCHEMISTRY ON TISSUE SECTIONS

A total of 42 breast carcinomas was analysed for the simultaneous expression of cytokeratin and ER or cytokeratin and PR, next to DNA content. When the steroid hormone receptorpositive and steroid hormone receptor-negative cases were grouped separately a good correlation between immunohistochemistry and FCM was found for ER receptor content (table 2). Thirthy-two cases were positive for both assays. Eight out of 42 breast carcinoma samples were found negative with both assays. Two cases which were negative for ER, as determined by immunohistochemistry, contained a small percentage of strongly ER-positive normal duct epithelial cells. When analysed by FCM these ER-positive cells were DNA-diploid cells, 
whereas the DNA-aneuploid tumor cells were devoid of ER staining. These two samples were therefore classified negative in both assays. For PR receptor content analysis a discrepancy was found in 2 out of 42 cases. Both cases were scored positive with immunohistochemistry, whereas the FCM analysis showed less than $5 \%$ positive cells. In both cases immunohistochemistry showed low numbers of positive cells with very low levels of immunoreactivity. In all other cases a good correlation was found.
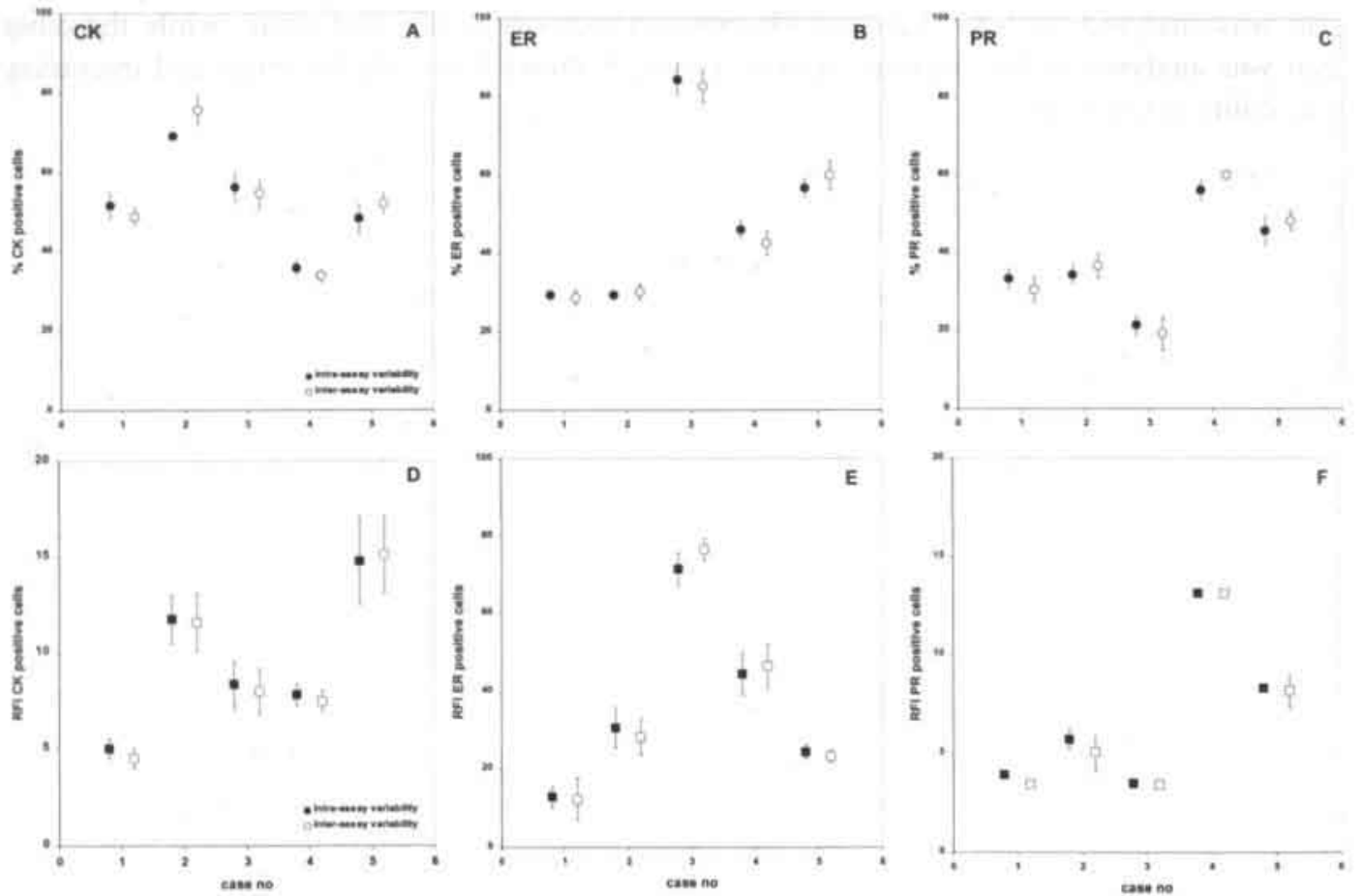

Figure 3 Intra- and interassay variability of trivariate cytokeratin/hormone recptor/DNA FCM analysis. Intra-assay variability was determined by duplicate analysis of 5 consequtive tissue sections of the same tumor sample within one assay, Interassay varaiability was determined by analysis of 5 consecutive tissue sections of the same tumor sample in 5 separate assays. The mean number and standard deviation (SD) of positive cells for cytokeratin, ER and PR are shown in $\mathbf{a , b}$ and $\mathbf{c}$, respectively, whereas the relative fluorescence intensity (RFI) and SD is shown in $\mathbf{d}, \mathbf{e}$ and $\mathbf{f}$.

Table 2 Comparison of the results of immunohistochemistry and flow cytometry for $\mathrm{ER}$ and $\mathrm{PR}$ in paraffin embedded breast carcinomas

\begin{tabular}{|l|lll|lll|}
\hline FCM & $\begin{array}{l}\text { ER-IH } \\
\text { Negative }\end{array}$ & Positive & Total & $\begin{array}{l}\text { PR-IH } \\
\text { Negative }\end{array}$ & Positive & Total \\
\hline Negative & 10 & 0 & 10 & 15 & 2 & 17 \\
Positive & 0 & 32 & 32 & 0 & 25 & 25 \\
\hline Total & 10 & 32 & 42 & 15 & 27 & 42 \\
\hline
\end{tabular}

In order to investigate the correlation between the two methods, i.e. immunohistochemistry and FCM, in more detail the percentage of steroid hormone receptor-positive epithelial cells, as determined by FCM, was compared with the semiquantitative immunohistochemical score of ER- or PR-stained tissue sections (fig. 4). For ER as well as PR a statistically significant correlation $(r=0.87$ and $r=0.62$ respectively, $p<0.0001)$ was found between the fraction of 

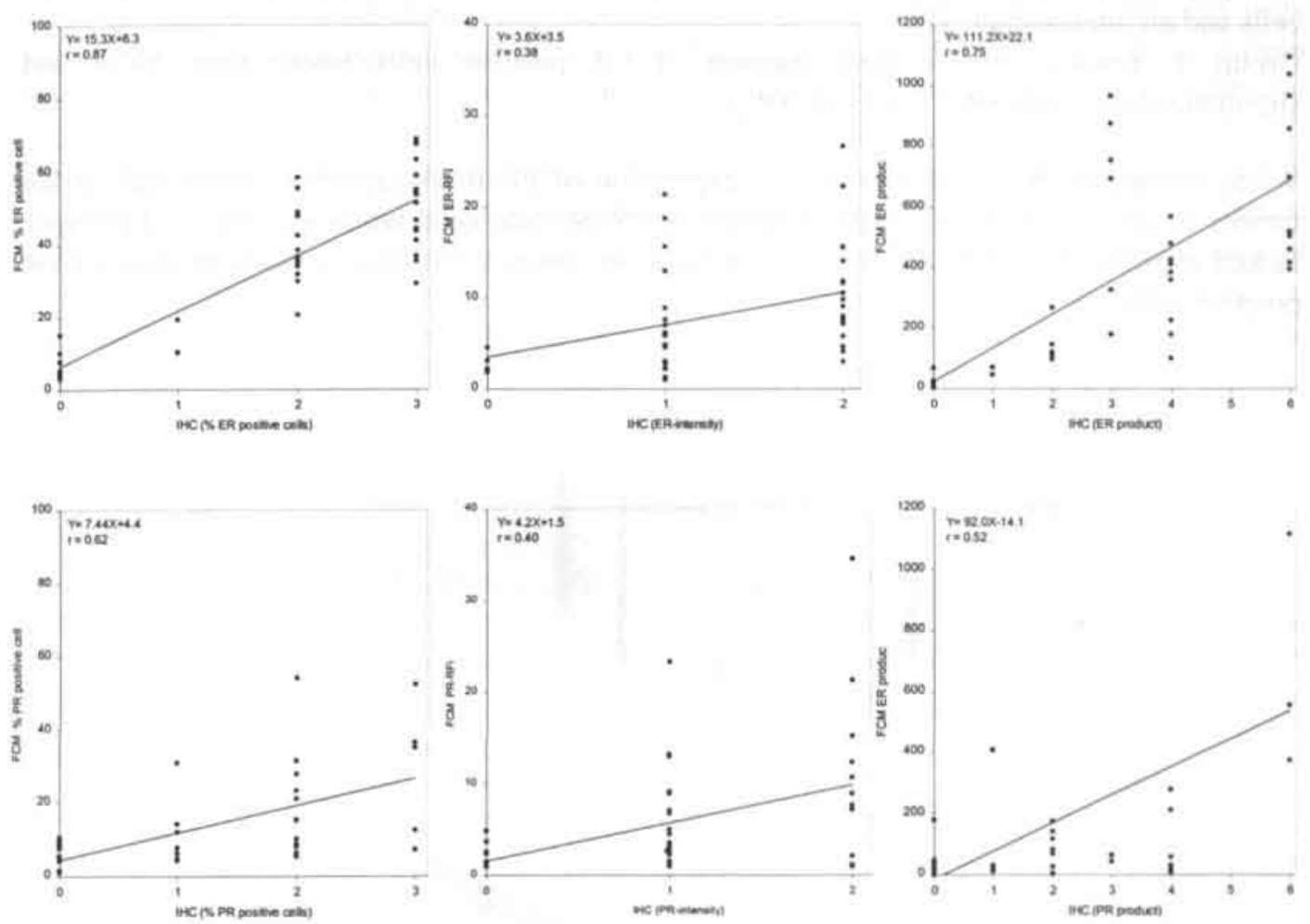

hormone receptor positive cells as determined by FCM and immunohistochemistry. Next to the percentage of hormone receptor positive epithelial cells, the relative fluorescence intensity Figure 4 Comparison between immunohistochemistry and FCM analysis for presence of ER (a) and PR (b). The left graph on each row shows the correlation between the fraction of steroid hormone receptor positive cells as determined by immunohistochemistry and FCM (in the cytokeratin-positive compartment). Although somewhat weaker for PR, a significant correlation $(\mathrm{p}<0.0001)$ was found for both steroid hormone receptors. The middle graph shows the correlation between the intensity of the steroid hormone receptor staining as determined by the two methods. No correlation was found here. The right graph finally shows the product of the fraction of steroid hormone receptor positive cells and the intensity of the staining of the immunohistochemistry and the FCM analysis.

(RFI) of the steroid hormone receptor-immunostaining as determined by FCM after selection of the cytokeratin-positive cells was plotted against the staining intensity of the hormone receptors as determined by the immunohistochemical score (Fig. 4). No correlation between RFI and the immunohistochemistry was found. In addition to the quantification of hormone receptor positive epithelial cells (for an example see fig. 5), the DNA-histograms (mean CV's $=3.02 \%)$ also allowed accurate DNA-ploidy determinations and cell cycle analyses. In this way the steroid hormone receptor reactivity of the relevant epithelial (tumor) cells could directly be correlated to the ploidy status and the growth potential of these cells (Fig. 6). It became clear from figure 6 a that three subpopulations of tumors could be recognized:

Group 1: tumors with a small fraction of ER positive cells (less than $20 \%$ ) and an intermediate and high SPF 
Groupe 2: an intermediate group of tumors with a relatively high percentage of ER positive cells and an intermediate SPF

Group 3: tumors with a great fraction of ER positive cells (more than 30\%) and simultaneously a low SPF (less than $10 \%$ ).

When comparing these results with the expression of PR it appears that almost half of the tumors of group 3 had also a large fraction of PR positive cells while all tumors of group 1 lacked expression of PR. All but two tumors from group 2 had also a small fraction of PR positive cells.
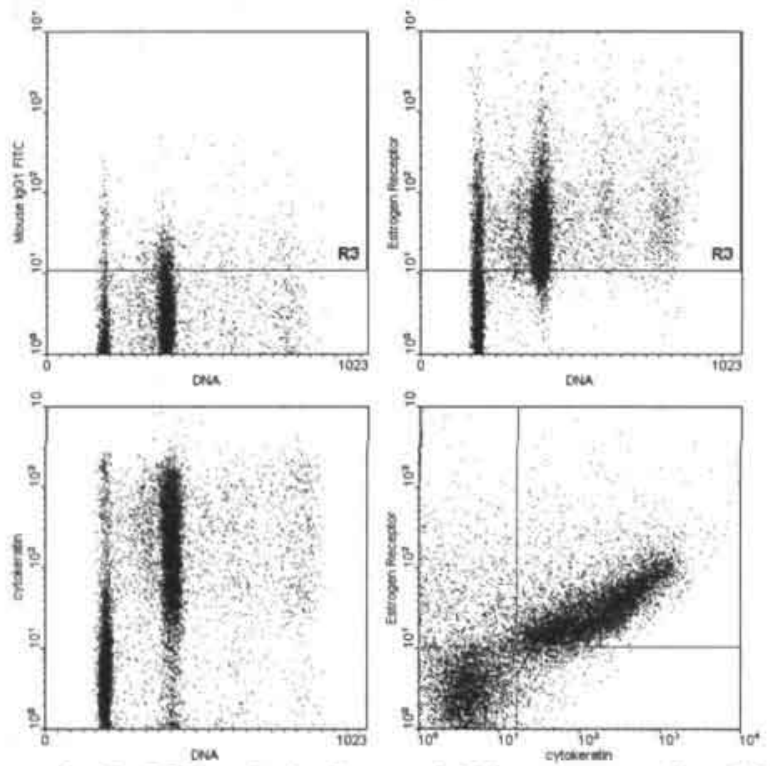

Figure 5 An example of a FCM analysis of a tetraploid breast tumor with a high expression of estrogen receptors (ER). Cells were stained in suspension for cytokeratin, ER and DNA. A shows the dotplot of DNA ( $\mathrm{x}$-axis) vs negative control. $\mathbf{B}$ and $\mathbf{C}$ show a dotplot of DNA-content (X-axis) vs ER and cytokeratin, respectively. The solid lines denote the treshold for positivity based on the negative control (B). D finally shows the dotplot of cytokeratin ( $\mathrm{x}$-axis) vs ER. From panel $\mathrm{C}$ it became clear that the majority of cytokeratin positive cells are tetraploid. Note that these cytokeratin positive cells are also positive for ER whereas cytokeratin negative cells are negative for ER (D).

\section{Discussion}

From previous studies it is clear that parameters such as DNA ploidy, steroid receptor content and cell cycle characteristics each bear prognostic information in breast carcinoma $5,10,11,14,20,21,23,24,25,31,35$, but this information has not been used to its full extent due to technical limitations and/or the composition of the material. For instance, single parameter DNA flow cytometry has frequently been used to determine ploidy levels and cell cycle characteristics, but this approach is hampered by the fact that tumor biopsies not only consist of tumor cell, but actually contain a heterogeneous mixture of epithelial cells (normal and tumor), fibroblasts and vascular stromal components, as well as inflammatory cells. In this way small subsets of 
DNA-aneuploid cells escape detection and more importantly, cell cycle characteristics are often not informative, for instance in case of DNA-diploidy or in case of insufficient peak separation in DNA-peridiploid tumors. This drawback applies to cell suspensions derived from both fresh or paraffin embedded tissues, but can now be overcome by selection of epithelial cells for ploidy measurements by means of bivariate cytokeratin/DNA analysis 15-17. Determination of steroid hormone receptor content is hampered by similar drawbacks ${ }^{30}$. Quantitative data on steroid hormone receptor content can be obtained with the cytosol-based ligand-binding assays ${ }^{13}$. However, these techniques do not compensate for the presence of non-relevant cells, such as stromal and inflammatory cells in the sample. This inherent drawback has been circumvented by the immunocytochemical detection of steroid receptors in tissue sections or cytological preparations ${ }^{5,27,32}$. This approach, however, is sensitive to many external factors interfering with accurate quantification of receptor content. For instance, staining intensity is influenced by the duration of fixation, thickness of the tissue section, incubation conditions of the primary antibodies, concentration of the chromogens and often subjective scoring of the investigators.

Despite these limitations all individually determined parameters apparently bear prognostic relevant information. However, it is reasonable to assume that accurate and combined analysis of ploidy level, steroid receptor content and cell cycle characteristics of the relevant epithelial cells, will add to this information and might allow the detection of specific subsets of tumors and tumor cell populations, and help to predict the individuals response to therapy.

In the underlying study we applied our recently developed protocol for the multiparameter FCM analysis of formalin fixed, paraffin embedded material ${ }^{18}$ to a series of routinely processed breast carcinoma specimens. The aim of the study was to investigate the applicability of this protocol for the accurate enumeration of steroid receptor-positive, epithelial (tumor) cells, and to explore whether this multiparameter approach allows the detection of specific, clinically relevant subsets of tumors, based on ploidy level, steroid receptor expression and cell cycle characteristics.

We previously showed that heat pretreatment of dewaxed and rehydrated tissue sections resulted in increased cell recovery, improved quality of the obtained DNA histograms, and restoration of epitopes that were masked during formalin fixation ${ }^{18}$. Here we show that this improved protocol also allows reliable detection of steroid receptor content. Firstly, proteolytic digestion up to 15 minutes results in 1) sufficient recovery of cells, 2) steady levels of cytokeratin, estrogen and progesterone hormone receptor immunofluorescence and 3) high quality DNA histograms. Secondly, antibody binding kinetics reveal that overnight incubations at room temperature result in saturated antibody binding. Thirdly, intra- and interassay variability is low, i.e. less than $6 \%$. Finally, a significant correlation was found between the immunohistochemical determined fraction and the FCM derived percentage of steroid hormone receptor-positive cells. No correlation was found between the immunohistochemical and flow cytometric determined staining intensity of steroid hormone receptors. This finding is somewhat surprising, since we previously showed for cell lines that fluorescence intensity correlated well with the number of hormone binding sites ${ }^{30}$. Therefore we conclude that routinely determined immunohistochemical scores are based more on numbers of receptor-positive cells than on the staining intensity, which is difficult to interpret by the (subjective) human eye. Since the FCM analysis is performed on a per cell basis, 


\section{References}

1. Bloom HJG, Richardson WW. Histologic grading and prognosis in breast cancer. Br J Cancer 1957; 11: 359-377

2. Chambers JT, Carcangiu ML, Voynick IM, Schwartz PE. Immunohistochemical evaluation of estrogen and progesterone receptor content in 183 patients with endometrial cancer. Part II: Correlation between biochemical and immunohistochemical methods and survival. Am J Clin Pathol 1990; 94: 255-260

3. Dressler LG, Seamer LC, Owens MA, Clark GM, McGuire WL. DNA flow cytometry and prognostic factors in 1,331 frozen breast cancer specimens. Cancer 1988; 61: 420-427

4. Feichter GE, Mueller A, Kaufmann M, Haag D, Born IA, Abel U, Klinga K, Kubli F, Goerttler K. Correlation of DNA flow cytometric results and other prognostic factors in primary breast cancer. Int J Cancer 1988; 41: 823-828.

5. Foekens JA, Portengen H, Putten van WL, Peters HA, Krijnen HLJ, Alexieva-Figusch J, Klijn JGM. Prognostic value of estrogen and progesterone receptors measured by enzyme immunoassays in human breast tumor cytosols. Cancer Res 1989; 49: 5823-5858

6. Frierson HF Jr. Ploidy analyses and S-phase fraction determination by flow cytometry of invasive adenocarcinomas of the breast. Am J Surg Pathol 1991; 15; 358-367

7. Gamallo C, Palacios J, Suarez A, Pizarro A, Navarro P, Quintanilla M, Cano A. Correlation of E-Cadherin expression with differentiation grade and histological type in breast carcinoma. Am J Pathol 1993; 142: 987-993

8. Haghbin M, McCue PA, Mansfield CM, Komarnicky LT, Benammar A, Schwartz F. Correlation of flow cytometry to clinical factors, hormone receptors, and histopathological grade in stage I and II invasive breast carcinoma. Am J Clin Oncol 1996; 19(1): 54-58

9. Hedley DW, Rugg CA, Gelber RD. Association of DNA index and S-phase fraction with prognosis of nodes positive early breast cancer. Cancer Res 1987; 47: 4729-4735

10. Hedley DW, Clark GM, Comellise CJ, Killander D, Kute T, Merkel D. Consensus review of the clinical utility of DNA cytometry in carcinoma of the breast. Cytometry 1993; 14:482-485

11. Jensen EV. Hormone dependency of human breast cancer. Cancer 1980; 46: 2759-2761

12. Kauppila A. Estrogen and progesteron receptors as prognostic indicators in endometrial cancer. Acta Oncol 1989; 28: $561-566$

13. Kell DL, Kamel OW, Rouse RV. Immunohistochemical analysis of breast carcinoma estrogen and progesterone receptors in paraffin embedded tissue: correlation of clones ER1D5 and 1A6 with a cytosol-based hormone receptor assay. Appl Immunohistochem 1993; 1: 275-281

14. Klijn JGM, Berns EMJJ, Foekens JA. Prognostic factors and response to therapy in breast cancer. Cancer Survey 1993; 18: $165-198$

15. Leers MPG, Theunissen PHMH, Schutte B, Ramaekers FCS. Bivariate cytokeratin/DNA flow cytometric analysis of paraffin embedded samples from colorectal carcinomas. Cytometry 1995; 21: 101-107

16. Leers MPG, Theunissen PHMH, Koudstaal J, Schutte B, Ramaekers FCS. Trivariate flow cytometric analysis of paraffin embedded lung cancer specimens: application of cytokeratin subtype specific antibodies to distinguish between differentiation pathways. Cytometry 1997; 27: 179-188

17. Leers MPG, Theunissen PHMH, Ramaekers FCS, Schutte B. Multiparameter flow cytometric analysis with detection of the Ki67-Ag in paraffin embedded mammary carcinomas. Cytometry 1997; 27: 283-289

18. Leers MPG, Schutte B, Theunissen PHMH, Ramaekers FCS, Nap M. Heat pretreatment enables high resolution DNA flow cytometry of paraffin embedded tumor tissue. Cytometry 1999; 35: 260-266

19. Leers MPG, Kölgen W, Björklund V, Bergman T, Tribbick G, Persson B, Björklund P, Ramaekers FCS, Björklund B, Nap M, Jörnvall H, Schutte B. Immunocytochemical detection and mapping of a cytokeratin 18 neo-epitope exposed during early apoptosis. J Pathol 1999; 187: 567-572

20. Lippmann ME. Epidemiology of breast cancer. Diagnosis and management of breast cancer. D. Mauke-Saunders, Philadelphia 1988

21. Merkel DA, Osborne CK. Use of steroid receptor assays in cancer management. Rev Endocrinol Rel Cancer 1988; 30: $5-12$

22. Muss HB, Kute TE, Case LD, Smith LR, Booher C, Long R, Kammire L, Gregory B, Brockschmidt JK. The relation of flow cytometry to clinical and biological characteristics in women with node negative primary breast cancer. Cancer 1989; 64: 1894-1900

23. Nicholson RI, McClelland RA, Gee JMW. Steroid hormone receptors and their clinical significance in cancer. J Clin Pathol $1995 ; 48: 890-895$

24. Osborne CK, Yochmowitz MG, Knight WA, McGuire WL. The value of estrogen and progesterone receptors in the treatment of breast cancer. Cancer 1980; 46: 2884-2888 
25. Rayzter Z. Steroid receptors in breast cancer. Br J Surg 1991; 78: 528-535

26. Saati TA, Clamens S, Cohen-Knafo E, Faye JC, Prats H, Coindre JM, Wafflart J, Caveriviere P, Bayard F, Delsol G. Production of monoclonal antibodies to human estrogen-receptor proteïn (ER) using recombinant ER (RER). Int J Cancer 1993; 55: 654-654

27. Sannino $P$, Shousha $S$. Demonstration of oestrogen receptors in paraffin wax sections of breast carcinoma using the monoclonal antibody ID5 and microwave oven processing. J Clin Pathol 1994; 47: 90-92

28. Schlegel R, Banks-Schlegel S, McLeod JA, Pinkus GS. Immunoperoxidase localization of keratin in human neoplasms: a preliminary survey. Am J Pathol 1980; 101: 41-50

29. Schutte B, Reynders MMJ, Bosman FT, Blijham GH. Studies with antibromodeoxyuridine antibodies. II. Simultaneous detection of antigen expression and DNA synthesis by in vivo labeling of mouse intestinal mucosa. J Histochem Cytochem 1987; 35: 371-374

30. Schutte B, Scheres HME, De Goeij AFPM, Rousch MJM, Blijham GH, Bosman FT, Ramaekers FCS. Flow cytometric steroid receptor analysis. Progress Histo Cytochem 1992; 26; 68-76

31. Shek LL, Godolphin W. Survival with breast cancer: the importance of oestrogen receptor quantity. Eur J Cancer Clin Oncol $1989 ; 25 ; 243-250$

32. Snijders MPML, Theunissen PHMH, Debets-Te Baerts MJ, Koudstaal J. Immunocytochemical analysis of oestrogen and progesterone receptors in paraffin sections. Der Pathologe 1990; 11: 236-239

33. Walker KJ, McClelland RA, Candlish W, Blamey RW, Nicholson RI. Heterogeneity of oestrogen receptor expression in normal and malignant breast tissue. Eur J Cancer 1992; 28: 34-37

34. Wiley EL, Mulhollan TJ, Beck B, Tyndall JA, Freeman RG. Polyclonal antibodies raised against Bacillus Calmette Guerin, Mycobacterium duvalii and Mycobacterium paratuberculosis used to detect mycobacteria in tissue with the use of immunohistochemical techniques. Am J Clin Pathol 1990; 94: 307-312

35. Witliff JL. Steroid-hormone receptors in breast cancer. Cancer 1984; 53: 630-643 



\section{Clonality assessment of lymphoproliferative disorders by multiparameter flow cytometry of paraffin embedded tissue:}

\section{An additional diagnostic tool in surgical pathology}

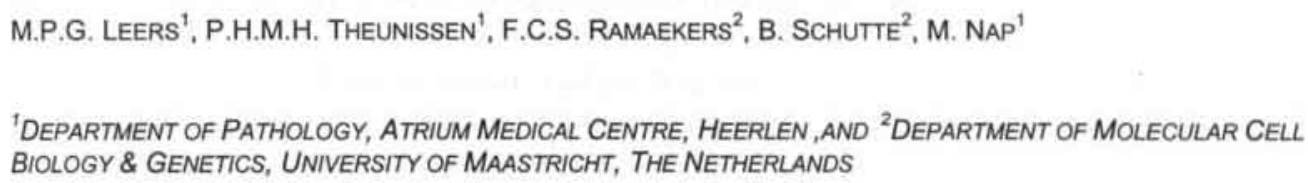

SUBMITTED 


\section{Abstract}

A major drawback of immunohistochemical detection of monoclonality in B-cell lymphoproliferative disorders is the lack of contrast between surface-immunoglobulin staining and extracellular immunoglobulin staining. To bypass this drawback immunophenotyping of single cell suspensions by flow cytometry is commonly used. Although the expression of immunoglobulin light chain subtype can be quantified rapidly and reliably, the technique is hampered by the requirement of fresh unfixed material.

Here we applied a recently developed technique for the isolation of single cells from formalin fixed, paraffin embedded material to measure clonality in B-cell lymphoproliferative disorders. For this purpose $50 \mu \mathrm{m}$ thick sections of formalin fixed, paraffin embedded archival samples of reactive lymphoid tissue $(n=10)$ and non-Hodgkin's B-cell lymphoma $(n=10)$ were used. After dewaxing and rehydration the samples were subjected to heat pretreatment for 2 hours at $80^{\circ} \mathrm{C}$ in a citrate solution. Single cell suspensions were prepared by a short trypsin digestion.

Immunocytochemistry revealed that common cell surface markers, such as CD3, CD20 and CD79a, as well as the immunoglobulin light chains could be detected in the cell suspensions derived from archival material. In addition, the technique also allowed combined high resolution DNA flow cytometric analysis. To investigate the effect of formalin fixation on cross-linking of extracellular immunoglobulins to lymphocytes, a double-immunostaining experiment for both light chain immunoglobulins ( $\kappa$ and $\lambda$ ) was performed. This experiment showed that this cross-linking was minimal (less than $2 \%$ ).

All cases of reactive lymphoid hyperplasia were DNA diploid and showed a polyclonal expression of immunoglobulin light chains. In contrast, in nine out of ten non-Hodgkin's Bcell lymphomas monoclonality was established on the basis of light chain expression, whereas only six out of nine cases were conclusive by immunohistochemistry. Four out of the nine cases were DNA aneuploid. One case did not show light chain expression at all by both techniques. However, this case could be classified as malignant by flow cytometric analysis due to the DNA aneuploid nature of the B-cell subpopulation. The average S-phase fraction (SPF) of the B-cells in the reactive lymphoid tissues was 3.5\%. The mean SPF values for Bcells in DNA-diploid cases of lymphomas was $3.0 \%$, whereas the mean SPF of B-cells in DNA-aneuploid cases was $6.1 \%$.

The presented technique is superior to immunohistochemistry for the detection of monoclonality in B-cell lymphoproliferative disorders and therefore provides a powerful tool to support the diagnosis of malignant lymphoma in routinely processed archival samples of lymphoid tissues.

\section{Introduction}

Immunophenotyping is widely used in the diagnosis and classification of lymphoproliferative disorders. For instance, establishing monoclonality in B-cell disorders plays a key diagnostic role in distinguishing neoplastic from reactive B-cell lymphocytosis ${ }^{18}$. These studies are usually performed on fresh frozen or formalin fixed, paraffin embedded tissues after antigen 
retrieval. Paraffin embedded tissues are often preferred because of their superior morphology. However, a major drawback of immunohistochemistry for the detection of B-cell monoclonality is the lack of contrast between surface immunoglobulin staining and extracellular immunoglobulin staining ${ }^{25}$. To circumvent this drawback phenotyping by flow cytometry has been used, offering high speed multiparameter analysis and statistical accuracy. Several studies have compared the flexibility of immunohistochemistry and flow cytometry, in this respect 7,19,22. These authors showed good correlations between both methods in the majority of investigated cases. Quantitative analysis of the expression of light chains in the Bcell lymphocyte compartment as offered by flow cytometry seems to be superior to immunohistochemistry. It has been suggested that a $\kappa / \lambda$ ratio of more than 3 or less than 0.5 is adequate for the diagnosis of monoclonality in the context of supporting clinical and morphological evidence of lymphoma ${ }^{27}$. However, this approach is limited by the availability of fresh, unfixed tissue, which often presents logistic problems in a routine setting.

In a recent study we have described a new technique for the isolation and subsequent flow cytometric analysis of single cells from formalin fixed, paraffin embedded tissue ${ }^{13}$. The technique is based on a heat pretreatment step after dewaxing and rehydration of the tissue sections, followed by a brief trypsin digestion. Using this method cell recovery was doubled as compared to commonly used protocols, the quality of the DNA histograms was significantly improved and the accessibility of several antigen epitopes, including those from steroid hormone receptors ${ }^{14}$ and membrane antigens (E-cadherin), was improved or restored.

The aim of the present study was to investigate whether this protocol could be used for immunophenotyping of lymphoproliferative disorders. For this purpose this multiparameter approach was used for lineage assignment and detection of monoclonality, next to establishment of DNA ploidy and cell cycle characteristics, in cells derived from formalin fixed, paraffin embedded tissues of B-cell lymphoproliferative disorders.

\section{Materials and methods}

\section{* LYMPHOID TISSUE SAMPLES}

Twenty cases of lymphoid proliferations were retrieved from the files of the Pathology department of Atrium Medical Centre Heerlen. The formalin fixed, paraffin embedded lymph node samples, were diagnosed as reactive lymphoid hyperplasia $(\mathrm{n}=10)$ or non-Hodgkin's lymphoma $(\mathrm{n}=10)$. The non-Hodgkin's lymphomas were classified according to the REALclassification (Revised European-American classification of Lymphoid neoplasms) ${ }^{9}$. Based on the morphological findings in conjunction with immunohistochemistry the cases of malignant B-cell non-Hodgkin's lymphomas had been classified as follicular lymphoma $(n=4)$, diffuse large B-cell lymphoma $(n=2)$, B-cell small lymphocytic lymphoma $(n=2)$, nodal marginal zone B-cell lymphoma $(n=1)$ and mantle cell lymphoma $(n=1)$. These paraffin embedded tumor blocks were analysed using multiparameter DNA flow cytometry without knowing the diagnosis. All non-Hodgkin's lymphomas have been confirmed by a regional expert panel of pathologists as part of routine procedure. 


\section{* IMMUNOHISTOCHEMISTRY}

Tissue sections ( $4 \mu \mathrm{m}$ thick) were cut from the paraffin embedded blocks, mounted on APEScoated slides and air-dried overnight at $37^{\circ} \mathrm{C}$. For immunostaining the sections were deparaffinized in xylene and rehydrated in a descending ethanol series. Endogeneous peroxidase activity was blocked by immersion for 10 minutes in $3 \%$ hydrogen peroxide in methanol, after which the slides were rinsed in phosphate buffered saline (PBS; $\mathrm{pH}=7.2-7.4$ ). The slides were placed in a $0.1 \mathrm{M}$ citrate solution $(\mathrm{pH}=6.0)$ and boiled for 10 minutes in a microwave oven at $750 \mathrm{~W}$. After preïncubation with $1 \%$ bovine serum albumin (Sigma, St Louis, MO, USA)/PBS (BSA/PBS-buffer) for 10 minutes , the primary antibody was applied at the appropriate dilution (Table 1) for 1 hour at room temperature (RT). After washing in PBS, the appropriately diluted secondary antibody was applied for 45 minutes at room temperature. In case of monoclonal primary antibodies biotin-labelled goat anti-mouse-Ig was applied, and in case of the polyclonal rabbit antiserum biotin labelled swine anti-rabbit-Ig was used in the second step (both 1:400 diluted; DAKO A/S). After washing in PBS, the slides were incubated with streptavidin conjugated with horseradish peroxidase (1:600; DAKO A/S). After washing in PBS, peroxidase-activity was detected with 3,3-diaminobenzidine (Sigma)/$0.002 \% \mathrm{H}_{2} \mathrm{O}_{2}$-solution . Finally, the sections were counterstained with Harris' haematoxylin, dehydrated, cleared in xylene and finally mounted in Entellan.

Table 1. Primary antibodies used in this study

\begin{tabular}{|l|c|c|c|c|}
\hline Antigen & Clone/cat.no & Mono-/ polyclonal & Dilution & Ref. \\
\hline CD3 (pan T) & A0452 & Rabbit polyclonal & $1: 33$ & 16 \\
CD20 (pan B) & L26 & Mouse monoclonal & $1: 33$ & 8 \\
CD79a (pan B) & JCB117 & Mouse monoclonal & $1: 20$ & 17 \\
K-light chain & A0191 & Rabbit polyclonal & $1: 500$ & 21 \\
$\lambda$-light chain & A0193 & Rabbit polyclonal & $1: 500$ & 21 \\
K-light chain-FITC & F0340 & Rabbit polyclonal & $1: 500$ & 21 \\
$\lambda$-light chain-RPE & R0436 & Rabbit polyclonal & $1: 500$ & 21 \\
Neg. Controls: & X0931 & Mouse monoclonal & $1: 20$ & - \\
Mouse Ig & X0903 & Rabbit polyclonal & $1: 20$ & - \\
Rabbit Ig & X0927 & Mouse monoclonal & $1: 20$ & - \\
Mouse Ig-FITC & X0930 & Rabbit polyclonal & $1: 20$ & - \\
Rabbit Ig-RPE & & & & \\
& & & \\
\hline
\end{tabular}

All antibodies used were from DAKO A/S. * = antibodies used as negative control. Cat.no= catalogus number

\section{* Preparation of cell suspensions}

From each of the routinely processed paraffin embedded tissues, $50 \mu \mathrm{m}$ thick sections were cut. These were deparaffinized in xylene and rehydrated in a descending ethanol series. The sections were then immersed in cold citrate solution $(2 \mathrm{mg}$ citric acid/ml aqua dest, $\mathrm{pH}=6.0$ ) and placed in a water bath at $80^{\circ} \mathrm{C}$ for $2 \mathrm{hrs}$. After a 15 minutes cooling period sections were rinsed in PBS. The sections were digested in a solution of $1 \mathrm{mg}$ trypsin (type II from porcine pancreas, Sigma, St. Louis, MO) and $1 \mathrm{mg} \mathrm{CaCl} 2$ in $1 \mathrm{ml}$ TRIS buffered saline (TBS; $\mathrm{pH}=$ 7.6) for 5 minutes at $37^{\circ} \mathrm{C}$. The sample was then filtered through a $50 \mu \mathrm{m}$ mesh nylon filter, and the cell suspension was centrifugated at $400 \mathrm{~g}$. The pellet was resuspended in $1 \%$ BSA/PBS-buffer. 


\section{* IMMUNOLABELING FOR FLOW CYTOMETRY}

A double label indirect fluorescence technique with fluorescein isothyocyanate (FITC)- and rphycoerythreïn (RPE)- conjugated secondary antibody reagents was used. The characteristics of the antibodies used are described in Table 1. All antibodies were derived from DAKO A/S (Glostrup, Denmark). The single cell suspension was aliquoted into $100 \mu \mathrm{l}$ samples $\left( \pm 10^{7}\right.$ cells $/ \mathrm{ml}$ ). To each sample both primary antibodies (appropriate diluted, see table 1) were added simultaneously, i.e. a polyclonal rabbit antiserum in combination with a monoclonal mouse antibody. Lineage assignment was performed by dual color analysis using monoclonal CD79a in combination with a polyclonal antibody against CD3. For immunoglobulin light chain distribution a dual color analysis was performed using a monoclonal antibody directed against CD79a in combination with polyclonal anti- $\kappa$ or anti- $\lambda$. After $1 \mathrm{hr}$ incubation at room temperature the samples were rinsed twice in PBS. Binding of primary antibodies was visualized by incubating the cell pellet simultaneously with both the secondary antibodies: goat-anti-mouse-Ig-RPE, 1:15 (DAKO A/S) and swine-anti-rabbit-Ig-FITC, 1:10 (DAKO $\mathrm{A} / \mathrm{S})$. After incubation for $1 \mathrm{hr}$ at room temperature, the samples were rinsed twice in PBS and finally counterstained with propidium iodide $(1.0 \mu \mathrm{g} / \mathrm{ml}$ PI, Sigma) in PBS $(\mathrm{pH} 7.4)$ containing $0.1 \mathrm{mg} / \mathrm{ml}$ RNAse (Serva, Heidelberg, Germany). The samples were allowed to stand for 15 minutes on ice in the dark before flow cytometric (FCM) analysis.

To investigate the effect of formalin fixation on cross-linking of serum immunoglobulins to lymphocytes, single cells of a non-Hodgkin's lymphoma (case no. 2) were simultaneously incubated with FITC-conjugated polyclonal $\kappa$ - and RPE-conjugated polyclonal $\lambda$-antibody at the same dilutions as the non-conjugated ones.

\section{* Multiparameter flow Cytometry}

All samples were analysed using a FACScan flow cytometer (Becton Dickinson, San Jose, CA, USA). Cells were excited with a single $488 \mathrm{~nm}$ argon laser. FITC fluorescence was detected through a $515-545 \mathrm{~nm}$ BP filter, RPE-fluorescence through a 572-588 nm BP filter and PI-fluorescence through a $572-588 \mathrm{~nm}$ BP filter. Electronic gating was used to exclude doublets and cellular debris. At least 20,000 events were collected for each sample. FITC- and RPE-signals were recorded as logarithmic amplified data, while the PI-signals were recorded as linear amplified data. The following settings were used: $450 \mathrm{~V}, 380 \mathrm{~V}$ and $412 \mathrm{~V}$ on photomultiplier tubes for FL1 (FITC), FL2 (PE) and FL3 (PI), respectively. Compensation for (FL1-\%FL2), (FL2-\%FL1), (FL2-\%FL3) and (FL3-\%FL2) was 0.9\%, 23.5\%, 12.6\% and $5.6 \%$, respectively. Data analysis was performed using Lysys II software (Becton Dickinson). A light chain ratio was calculated by dividing the percentage of CD79a positive cells staining exclusively with $\kappa$ by the percentage of cells staining exclusively with $\lambda$. A $\kappa / \lambda$ ratio higher than 3 or lower than 0.5 is considered indicative for monoclonality ${ }^{27}$. Cell cycle analysis was performed using the ModFit LT 2.0 software (Verity Software House,Inc, ME). The following data were collected: 1) the percentage of the CD79a- and CD3-positive lymphocytes; 2) the percentage of $\kappa$ - and $\lambda$-light chain expressing CD79a positive lymphocytes; 3 ) the DNA index of the tumor cells and the coefficient of variation (CV) of the first $G_{0} / G_{1}$ peak and 4) the $S$ phase fraction (SPF) of the CD79a-positive population. 


\section{Results}

Microscopic examination of the fluorescently labeled cell suspension showed that these suspensions contained predominantly intact lymphocytes. Examination of the immunostained single cells by fluorescence microscopy revealed that the antigenic epitopes for CD3, CD20 and CD79a were indeed retrieved on the cell surface. For CD79a as well as for the $\kappa$ and $\lambda$ light chains, a membraneous or a cytoplasmic staining pattern was observed. Examination of the double-staining experiment to test the effect of formalin fixation on cross-linking of extracellular immunoglobulins to the surface of lymphocytes revealed that the population which is positive for $\kappa$ - as well as $\lambda$-light chain immunoglobulins is only $1.6 \%$ (Fig. 1 ). The epitopes recognized by the antibodies L26 (CD20cy) and JCB117 (CD79a), are both expressed throughout B-cell differentiation and are B-cell specific. For this reason, these antibodies are used in the present study in a multiparameter FCM assay for the selection of the B-lymphocytes. There was almost no difference in the number of B-lymphocytes stained for L26 (data not shown) and CD79a. However a better discrimination between immunopositive and -negative cells could be made when we used CD79a as B-cell marker.

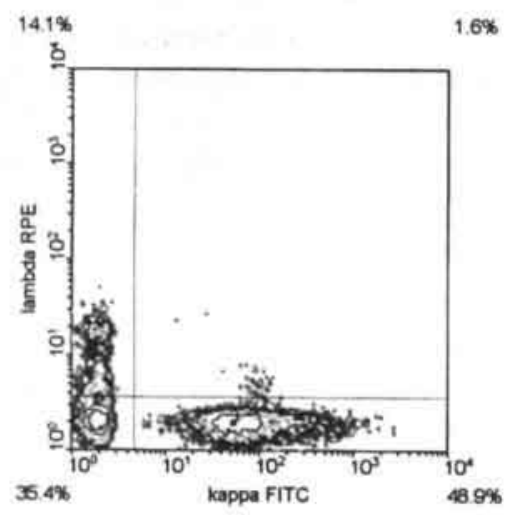

Figure 1. Double labeling of a single cell suspension of a non-Hodgkin's lymphoma, with directly labeled $k$ - and $\lambda$-antibodies, showing the mutual exclusiveness of both antibody reactions. This indicates that formalin fixation does not cross-link the extracellular immunoglobulins to the cell surface.

Table 2. FCM characteristics of reactive hyperplastic lymphatic tissue

\begin{tabular}{|c|c|c|c|c|c|c|}
\hline Case no. & $\%$ B cells & $\%$ T cells & DNA-index & $\begin{array}{c}\text { CV } \\
\%\end{array}$ & $\begin{array}{c}\text { SPF } \\
\%\end{array}$ & $\kappa / \lambda$ ratio \\
\hline & & & & & & \\
2 & 45 & 30 & 1.00 & 3.36 & 4.04 & 0.79 \\
3 & 58 & 9 & 1.00 & 2.46 & 8.57 & 1.02 \\
4 & 31 & 16 & 1.00 & 3.66 & 1.56 & 1.05 \\
5 & 41 & 47 & 1.00 & 3.76 & 1.16 & 0.87 \\
6 & 32 & 38 & 1.00 & 3.38 & 5.29 & 1.06 \\
7 & 37 & 32 & 1.00 & 2.98 & 2.93 & 0.95 \\
8 & 42 & 57 & 1.00 & 4.97 & 3.50 & 1.03 \\
9 & 30 & 50 & 1.00 & 4.28 & 1.91 & 1.09 \\
10 & 40 & 42 & 1.00 & 3.95 & 3.57 & 0.57 \\
& 35 & 47 & 1.00 & 3.95 & 2.35 & 0.86 \\
\hline Mean \pm SD & $39 \pm 8$ & $37 \pm 15$ & 1.00 & $3.68 \pm 0.7$ & $3.49 \pm 2.18$ & \\
\hline
\end{tabular}

All cases were diploid; $\mathrm{CV}=$ coefficient of variation; $\mathrm{SPF}=\mathrm{S}$ phase fraction; $\mathrm{MFI}=$ mean fluorescence intensity; $\mathrm{SD}=$ standard deviation 


\section{* REACTIVE LYMPHOID HYPERPLASIA (FIG. 2; TABLE 2)}

The percentage of reactive B-lymphocytes $(\mathrm{CD} 79 \mathrm{a}+)$ in the reactive hyperplastic lymph nodes ranged from $31 \%$ to $58 \%$, while the fraction of reactive T-lymphocytes (CD3+) varied from $9 \%$ to $57 \%$. Figure 2 shows an example of such a multiparameter CD3/CD79a DNA flow cytometric analysis. The range of the $\kappa / \lambda$-ratio as determined by FCM was 0.57 to 1.09 . No case had a ratio less than 0.5 or greater than 3. DNA analysis of these suspensions showed that all cases were diploid with a S-phase fraction ranging from $1.16 \%$ to $8.57 \%$ (mean $3.49 \%$ ). The coefficient of variation (CV) of the G0/G1-peak in the DNA histogram ranged from $2.46 \%$ to $4.97 \%$ (mean $3.68 \%$ ).

Table 3. FCM characteristics of the non-Hodgkin lymphomas

\begin{tabular}{|c|c|c|c|c|c|c|c|c|c|}
\hline $\begin{array}{l}\text { Case } \\
\text { no. }\end{array}$ & $\begin{array}{c}\text { Histologic subtype diagnosis } \\
\text { Malignant lymphoma: }\end{array}$ & $\begin{array}{c}\text { CD79+ } \\
\text { cells }\end{array}$ & $\begin{array}{c}\text { CD3+ } \\
\text { cells }\end{array}$ & $\begin{array}{l}\text { DNA- } \\
\text { index }\end{array}$ & Ploidy & $\begin{array}{l}\mathrm{CV} \\
\%\end{array}$ & $\begin{array}{l}\text { SPF } \\
\%\end{array}$ & $\begin{array}{l}\kappa / \lambda \\
\text { ratio }\end{array}$ & $\begin{array}{l}\text { Light chain } \\
\text { Phenotype }\end{array}$ \\
\hline 1 & B-cell small lymphocytic & 69 & 2 & 1.05 & Aneuploid & 1.98 & 1.30 & 4.40 & K \\
\hline 2 & Diffuse largẽ B-cell & 54 & 45 & 1.00 & Diploid & 3.67 & 3.83 & 3.83 & $\kappa$ \\
\hline 3 & Follicular & 49 & 39 & 1.00 & Diploid & 3.25 & 4.41 & 15.67 & $\kappa$ \\
\hline 4 & Diffuse large B-cell & 44 & 47 & 1.21 & Aneuploid & 3.49 & 7.49 & 5.00 & $\kappa$ \\
\hline 5 & B-cell small lymphocytic & 56 & 18 & 1.05 & Aneuploid & 1.90 & 2.53 & 0.45 & $\lambda$ \\
\hline 6 & Follicular & 60 & 30 & 1.00 & Diploid & 3.90 & 2.30 & 0.43 & $\lambda$ \\
\hline 7 & Mantle cell & 88 & 10 & 1.00 & Diploid & 3.37 & 1.65 & 0.14 & $\lambda$ \\
\hline 8 & Follicular & 55 & 15 & 1.09 & Aneuploid & 3.58 & 3.13 & 0.31 & $\lambda$ \\
\hline 9 & Follicular & 80 & 6 & 1.18 & Aneuploid & 4.20 & 15.88 & n.a & $\begin{array}{l}\text { No light } \\
\text { chain }\end{array}$ \\
\hline 10 & Nodal marginal zone B cell & 72 & 25 & 1.00 & Diploid & 3.68 & 2.97 & 0.33 & $\lambda$ \\
\hline Mean & & 63 & 24 & & & 3.30 & 4.55 & & \\
\hline SD & & 14 & 16 & & & 0.77 & 4.35 & & \\
\hline
\end{tabular}

$\mathrm{L}=$ lymphoma; $\mathrm{CV}=$ coefficient of variation; $\mathrm{SPF}=\mathrm{S}$ phase fraction; $\mathrm{K}=$ kappa light chain; $\lambda=$ lambda light chain; $\mathrm{SD}=$ standard deviation, n.a.= not applicable

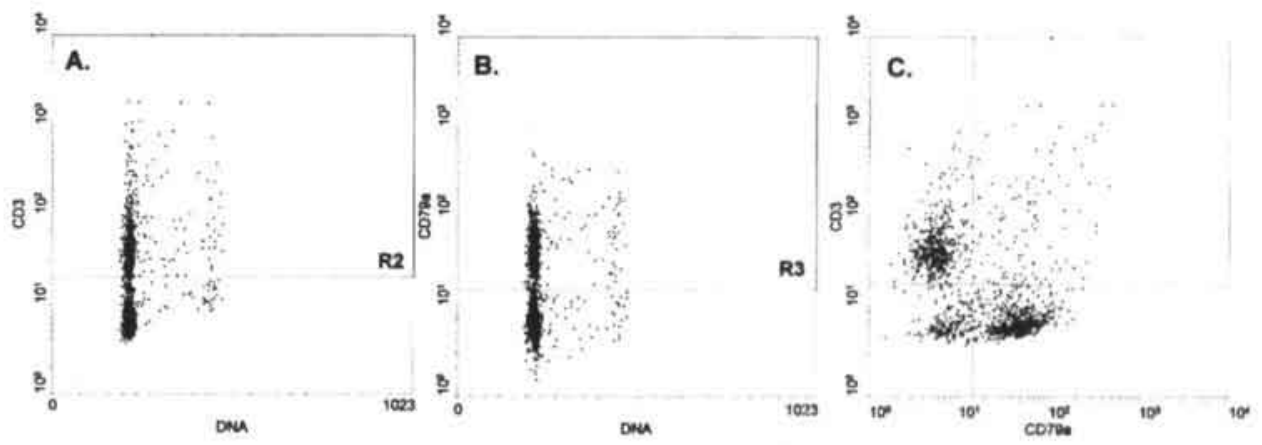

Figure 2. An example of a flow cytometric analysis of a reactive hyperplastic lymph node. Cells were stained in suspension with CD3, CD79a and propidium iodide. Panel A. shows a dotplot of DNA content ( $\mathrm{x}$-axis) vs. CD3 ( $\mathrm{y}$ axis) Panel B. shows the signal of CD79a vs. DNA. Panel C. shows CD79a vs. CD3. Three cell populations can be distinguished, i.e. a population only positive for CD3 (T-lymphocytes), a population only positive for CD79a (Blymphocytes) and a population negative for both. 


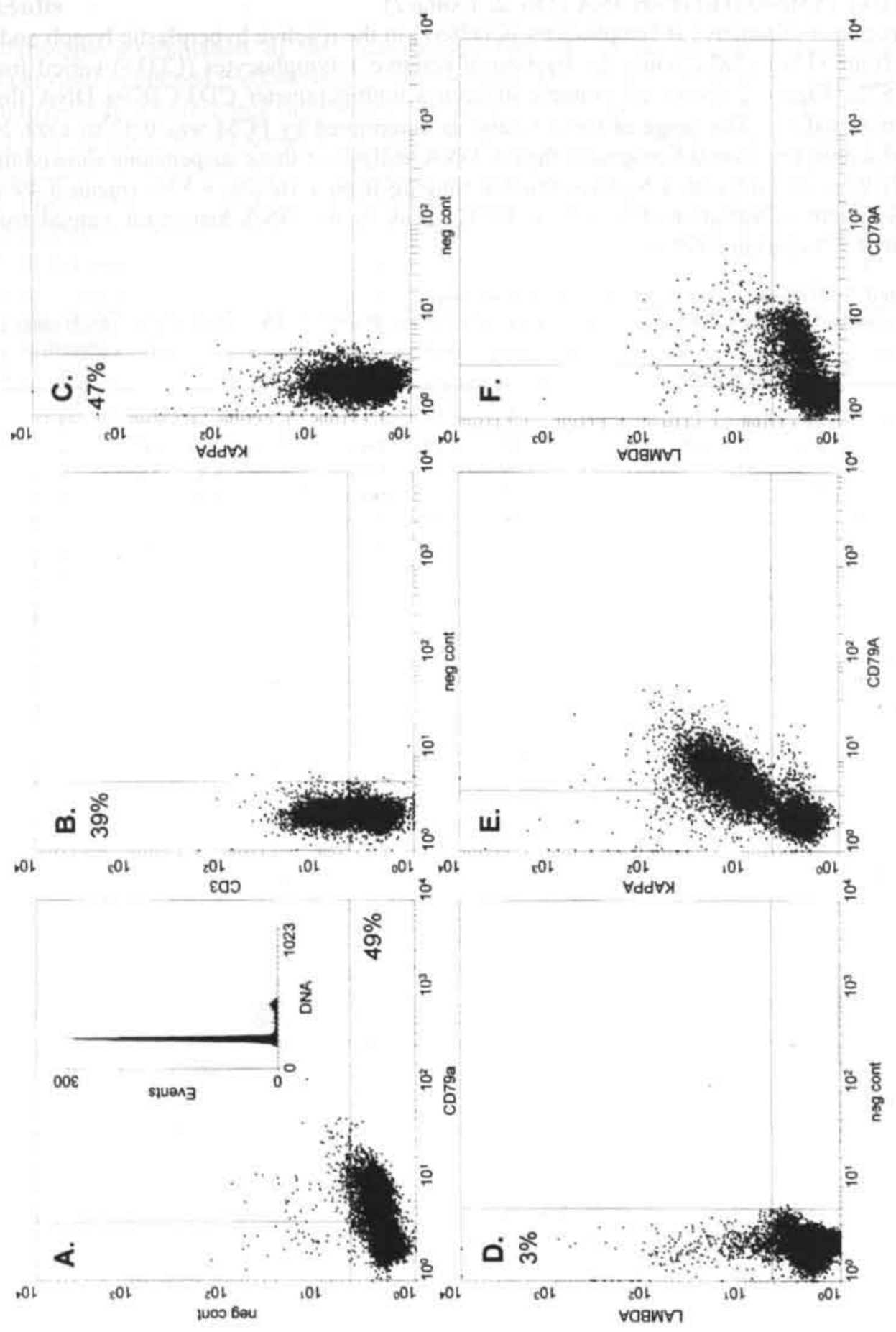


Figure 3. An example of a detailed multiparameter flow cytometric analysis of a non-Hodgkin's B-cell lymphoma (case no. 3, follicular lymphoma). The tumor cells were stained in suspension with monoclonal antibodies directed against $\mathrm{CD} 79 \mathrm{a}, \mathrm{CD} 3$, polyclonal anti- $\mathrm{K}$, polyclonal anti- $\lambda$ and propidium iodide. Panels $\mathrm{A}$. and $\mathrm{B}$. show the different single label controls for the FITC- and RPE-fluorescence signals. In A. cells are only stained for CD79a while in B. cells are stained with CD3. Panels C. and D. show the expression of the light chains with the majority of the cells $(47 \%)$ expressing $k$-light chains. In panels $\mathrm{E}$, and $\mathrm{F}$, cells are double-stained with $\mathrm{CD} 79 \mathrm{a}$ and $\kappa$ or $\lambda$. The B-cells which are selected by CD79a immunostaining are almost all expressing $\mathrm{K}$ as shown in panel $\mathrm{E}$.

\section{* NON-HODGKIN'S B-CELL LYMPHOMA (FIG. 3; TABLE 3)}

Flow cytometric analysis of non-Hodgkin's B-cell lymphomas showed that nine out of ten cases exhibited a monoclonal expression for one of the light chains. The $\kappa / \lambda$-ratio determined by FCM ranged from 0.14 to 15.67 . Four out of ten cases showed monoclonality of the $\kappa$-light chain (e.g. fig. 3), while the five other cases had a monoclonal expression of the $\lambda$-light chain. DNA-analysis of the non-Hodgkin's lymphomas revealed that five out of ten cases were aneuploid with a $\mathrm{CV}$ of the $\mathrm{G}_{0} / \mathrm{G}_{1}$ peak of the normal diploid cells ranging from $1.90 \%-4.20 \%$ (mean 3.30\%). The S-phase fraction of the aneuploid neoplastic lymphoid tissues ranged from $1.30 \%$ to $15.88 \%$ (mean $6.07 \%$ ) while that of the diploid lymphomas was lower, i.e. $1.65 \%$ to $4.41 \%$ (mean $3.03 \%$ ). One case showed no expression of light chains in both immunohistochemistry as well as flow cytometry. However, the tumor cells of this case were aneuploid. In this particular case the diploid lymphocytes showed a polyclonal expression of the $\kappa$ - and $\lambda$-light chain immunoglobulins.

\section{Discussion}

Using this approach we could discriminate between reactive lymphoid hyperplasia and malignant non-Hodgkin's B-cell lymphomas. Furthermore, the clonality assessment of the light chain expression on basis of flow cytometric analysis was in two cases superior to immunohistochemistry. In the hematopathology of B-cell disorders the detection of immunoglobulin expression with light chain restriction is still the most reliable criterion for the identification of B-cell non-Hodgkin's lymphomas. Until now, using standard techniques, the detection of immunoglobulins in formalin fixed, paraffin embedded material was less sensitive than in frozen tissue ${ }^{6,11,23,24}$. The malignant lymphocytes are often mixed with a reactive population of lymphocytes on the one hand and plasma cells expressing both types of light chains on the other.

An alternative technique that has been extensively used in the diagnosis of leukemia ${ }^{10}$ and lymphomas ${ }^{1-4,21,28}$ is the flow cytometric (FCM) analysis of the lymphoproliferative disorder. This technique offers some advantages over immunohistochemistry in terms of speed (analysing 10,000- 50,000 cells in a few minutes), multiple parameter analysis (including ploidy status and cell cycle phase distribution), quantitative information and fewer problems with non-specific background staining. With this technique it is possible to examine subpopulations of cells discernible on the basis of size, ploidy or immunophenotypic characteristics. Until now this technique could only be applied to fresh or frozen tissue samples, because enzymatic digestion steps, necesarry for the preparation of a single cell suspensions from paraffin embedded tissues, destroyed many epitopes, in particular those of the cell membrane bound antigens. However, fresh or frozen tissue is not always available. Recently we described a new protocol to prepare single cell suspensions from paraffin 
embedded tissues by a combined heating and brief enzymatic digestion step ${ }^{13}$. An improved DNA-histogram resolution, next to a high cell recovery and a good immunoreactivity was shown. In the present study we applied this protocol on formalin fixed, paraffin embedded lymphatic tissues. Heating in citrate solution is a widely used technique for heat induced epitope retrieval (HIER) in immunohistochemistry of formalin fixed, paraffin embedded tissue. Many of the antibodies directed to the cell membrane bound epitopes used in the diagnosis of lymphoproliferative disorders require such retrieval techniques. In this study it became apparent that after heating the lymphatic tissues, an enzymatic digestion step of five minutes was appropriate to release enough cells to perform the FCM analysis.

An advantage of this new approach is that when using multiparameter FCM neoplastic clones can be found by selecting cell populations by including the cell size information. These clones were otherwise obscured by reactive non-malignant B- or T-lymphocytes. When studying the light chain expression in the B-cell marker positive cells, it became apparent that the results obtained by immunohistochemistry correlated well with those obtained by FCM. However, the FCM analysis was superior for detection of light chain restriction in 2 of 10 malignant non-Hodgkin's lymphomas, because severe background staining in the tissue sections. One case concerned a nodal marginal zone B-cell lymphoma in which neither immunohistochemistry, nor PCR-analysis was conclusive. However, using cell size information and multiparameter FCM, a monoclonal neoplastic clone could be detected expressing only $\lambda$-light chains.The other case was a follicular lymphoma in which the neoplastic cells had no expression of light chain-immunoglobulins. However, these malignant lymphocytes were aneuploid while the normal diploid reactive lymphocytes showed a clear expression of $\kappa$-as well as $\lambda$-light chains.

Although applied to this limited series of routinely processed lymphoproliferative disorders, multiparameter FCM analyses revealed aneuploidy in five out of the ten investigated lymphomas (including the three peridiploid cases), while all reactive hyperplastic lymphoproliferative cases were diploid. In the literature there is large variation in reported percentages of cases with aneuploidy found by FCM. This varies from a small number ${ }^{1,2}$ up to $57 \%$ of the non-Hodgkin's lymphomas ${ }^{26}$. Overall DNA aneuploidy is encountered in $30 \%$ of non-Hodgkin's lymphomas when single parameter DNA FCM analyses are used ${ }^{15}$. On the other hand, when using multiparameter FCM analyses, combining a B-lymphocyte- and a light chain-marker on fresh tissue samples, Braylan and coworkers ${ }^{2}$ found abnormal DNA contents in $80 \%$ of their cases. These results emphasize the importance of a multiparameter approach for the detection of ploidy abnormalities in non-Hodgkin's lymphomas. The studies with low numbers of aneuploidy could suffer from the rather high CVs of the $\mathrm{G}_{0} / \mathrm{G}_{1}$-peaks found in single parameter FCM, due to admixture with cell debris. These wide $\mathrm{CV}$ can hide peridiploid cell populations which are than not recognized. In the underlying study DNA histogram resolution was optimal with a mean $\mathrm{CV}$ of $3.30 \%$. In accord with Macartney et al we found no tetraploid or multiple DNA peaks in our limited series.

In conclusion, our study demonstrates that when combining a heat pretreatment with a short trypsin digestion step for the isolation of single cell suspensions from non-Hodgkin's lymphomas, a proper clonality assessment can be performed by FCM. As a result, the technique allows the simultaneous evaluation of cell size and two cell membrane bound antigens on the same cell and provides quantitative information concerning immunophenotype, ploidy and cell cycle characteristics of formalin fixed, paraffin embedded 
lymphatic tissue. Therefore it can be an important aid in the diagnosis of lymphoproliferative disorders.

\section{References}

1. Braylan RC, Benson NA, Nourse VA. Cellular DNA of human neoplastic B-cells measured by flow cytometry. Cancer Res 1984; 44: 5010-5016

2. Braylan RC, Benson NA. Flow cytometric analysis of lymphomas. Arch Path Lab Med 1989; 113: 627-633

3. Braylan RC. Flow cytometric DNA analysis in the diagnosis and prognosis of lymphoma. Am J Clin Pathol 1993; 99 ; 374-380

4. Braylan RC. Lymphomas. In: Bauer KD, Duque RE, Shankey TV, editors. Clinical flow cytometry: principles and applications. Baltimore: Williams \& Wilkins; 1993, p. 203-234

5. Cartun RW, Coles FB, Pastuszak WT. Utilization of monoclonal antibody L26 in the identification and confirmation of B-cell lymphomas. A sensitive and specific marker applicable to formalin- and B5-fixed, paraffin embedded tissues. Am J Pathol 1987; 40: 1405-1412

6. Freedman AS, Boyd AW, Anderson KC, Fisher DC, Pinkus GS, Schlossman SF, Nadler LM. Immunological heterogeneity of diffuse large cell lymphoma. Blood 1985; 65: 630-637

7. Garcia C, Weiss L, Lowder J, Komoreske C, Link MP, Levy R, Warnke RA. Quantitation and estimation of lymphocyte subsets in tissue sections: a comparison with flow cytometry. Am J Clin Pathol 1987; 87: 470-477

8. Gelb AB, Rouse RV, Dorfman RF, Warnke RA. Detection of immunophenotypic abnormalities in paraffin-embedded B-lineage non-Hodgkin's lymphomas. Am J Clin Pathol 1994; 102: 825-834

9. Harris NL, Jaffe ES, Stein H, Banks PM, Chan JKC, Cleary ML, Delsol G, De Wolf-Peeters C, Falini B, Gatter KC, Grogan TM, Isaacson PG, Knowles DM, Mason DY, Muller-Hermelink HK, Pileri SA, Piris, MA, Ralfkiaer E, Warnke RA. A revised European-American classification of lymphoid neoplasms: a proposal from the international lymphorna study group. Blood 1994; 84: 1361-1392

10. Hirsch-Ginsberg C, Huh Yo, Kagan J, Liang JC, Stass SA. Advances in the diagnosis of acute leukemia. Hematol Oncol Clin North Am 1993; 7: 1-46

11. Horning SJ, Doggett RS, Warnke RA, Dorfman RF, Cox RS, Levy R. Clinical relevance of immunologic phenotype in diffuse large cell lymphomas. Blood 1984; 63: 1209-1215

12. Jeffers MD, Milton J, Herriot R, McKean M. Fine needle aspiration cytology in the investigation of non-Hodgkin's lymphoma. J Clin Pathol 1998; 51: 189-196

13. Leers MPG, Schutte B, Theunissen PHMH, Ramaekers FCS, Nap M. Heat pretreatment increases resolution in DNA flow cytometry of paraffin embedded tumor tissue. Cytometry 1999; 35:260-266

14. Leers MPG, Schutte B, Theunissen PHMH, Ramaekers FCS, Nap M. A novel flow cytometric steroid hormone receptor assay for paraffin embedded breast carcinomas: an objective quantification of the steroid hormone receptors and direct correlation to ploidy status and proliferative capacity in a single-tube assay. Hum Pathology 1999: in press.

15. Macartney JC, Camplejohn RS. DNA flow cytometry. Chapter 6 in Cell proliferation in lymphomas. Crocker J (ed). Blackwell Scientific Publications. Oxford 1993

16. Mason DY, Cordell $\Omega$, Brown $\mathrm{M}$ et al. Detection of cells in paraffin wax embedded tissue using antibodies against a peptide sequence from the CD3 antigen. J Clin Pathol 1989; 42: 1194-1200

17. Mason DY, Cordell J, Brown MH, Borst J, Jones M, Pulford K et al, CD79a: a novel marker for B cell neoplasms in routinely processed tissue samples. Blood 1995; 86: 1453-1459

18. Matutes E. Contribution of immunophenotype in the diagnosis and classification of hematopoietic malignancies. J Clin Pathol 1995: 48: 194-197

19. Robins DB, Katz RL, Swan F, Atkinsons EN, Ordonez NG, Huh YO. Immunotyping of lymphoma by fine-needle aspiration: a comparative study of cytospin preparations and flow cytometry. Am J Clin Pathol 1994; 101: 569-576

20. Rowan RM, Bain BJ, England JM, Hyde K, Matutes E, Stephens AD, Lewis SM, Shinton NK, Murphy MF, Wood JK. Immunophenotyping in the diagnosis of chronic lymphoproliferative disorders. J Clin Pathol 1994; 47: 871-875

21. Rothe G, Schmitz G, Adorf D, Barlage S, Gramatzki M, Hanenberg H, Höffkes HG, Janossy G, Knüchel R, Lüdwig WD, Nebe T, Nerl C, Orfao A, Serke S, Sonnen R, Tichelli A, Wörmann B. Consensus protocol for the flow cytometric immunophenotyping of hematopoietic malignancies. Leukemia 1996; 10: 877-895

22. Sinclair R, Bourne C, Jose D, Barr 1., Toh B. Lymphoma immunotyping by paraffin immunoperoxidase and cell suspension methods - a comparative study. Pathology 1986: 18: 321-327

23. Spier CM, Grogan ThM, Lippmann SM, Slymen DJ, Rybski JA, Miller ThP. The aberrancy of immunophenotype and immunoglobulin status as indicators of prognosis in B cell diffuse large cell lymphoma. Am J Pathol 1988; 133: 118 126

24. Strauchen JA, Mandeli JP. Immunoglobulin expression in B-cell lymphoma. Am J Clin Pathol 1991; 95: 692-695 
25. Taylor \& Cote. Immunomicroscopy: a diagnostic tool for the surgical pathologist. 2nd ed. W.B. Saunders \& Company, Philadelphia, USA 1994.

26. Winter JN, Andersen J, Variakojis D, Gordon LI, Fisher RI, Oken MM, Neiman RS, Jiang S, Bauer KD. Prognostic implications of ploidy and proliferative activity in the diffuse, aggressive non-Hodgkin's lymphomas. Blood 1996; 88: 3919-3925

27. Witzig TE, Banks PM, Stenson MJ, Griepp PR, Katzmann JA, Habermann TM, Colgan JP, Gonchoroff NJ. Rapid immunotyping of B-cell Non-Hodgkin's lymphomas by flow cytometry. Am J Clin Pathol 1990; 94: 280-286

28. Zaer FS, Braylan RC, Zander DS, Iturraspe JA, Almasri NM. Multiparametric flow cytometry in the diagnosis and characterization of low-grade pulmonary mucosa-associated lymphoid tissue lymphomas. Mod Pathol 1998; $11: 525$ 532. 


\section{Apoptosis, Bcl-2 expression and proliferation in endometrial adenocarcinoma;}

\section{an approach using multiparameter flow cytometry.}

H.M.MORSI ${ }^{1,3}$, M. P.G. LEERS ${ }^{2}$, M. RADESPIEL-TROGER ${ }^{4}$, V. BJORKLUND ${ }^{5}$, H. EL KABARITY ${ }^{3}$, M. NAP ${ }^{2}$ AND W. JÄGER ${ }^{1}$.

'DEPARTMENT OF OBSTETRICS \& GYNECOLOGY, FRIEDRICH ALEXANDER UNIVERSITY, ERLANGEN, GERMANY, ${ }^{2}$ DEPARTMENT OF PATHOLOGY, ATRIUM MEDICAL CENTRE, HEERLEN, THE NETHERLANDS, ${ }^{3}$ DEPARTMENT OF OBSTETRICS AND GYNECOLOGY, AIN SHAMS UNIVERSITY, CAIRO, EGYPT, “INSTITUTE OF MEDICAL INFORMATICS, BIOMETRY AND EPIDEMIOLOGY, FRIEDRICH ALEXANDER UNIVERSITY, ERLANGEN, GERMANY, ${ }^{5}$ BEKI DIAGNOSTICS AB, FREDSFORSSTIGEN 22, S-168 66 BROMMA, SWEDEN 


\begin{abstract}
Background: Neoplasms are the net result of an imbalance between cell proliferation and death. Consequently, abnormalities in apoptosis regulation may contribute to the pathogenesis of neoplasms. Expression of a neoepitope on cytokeratin 18, unmasked by an early caspase cleavage event and recognized by the novel monoclonal antibody M30, is an indicator of early apoptosis in epithelial cells. The purpose of this study was to evaluate the quantitative relation between apoptosis (M30), cell persistence (Bcl-2) and proliferation (S-phase fraction; SPF) in malignant and benign endometrium.
\end{abstract}

Methods: Using multiparameter DNA flow cytometric analysis of 54 formalin fixed, paraffin embedded samples, Bcl-2, M30 reactivity and SPF in cytokeratin positive epithelial cells were evaluated.

Results: Endometrial hyperplasia showed an increase in mean \% of Bcl-2 and M30 positivity from simple to complex hyperplasia. Within the carcinomas, well differentiated tumors showed the highest $\%$ of $\mathrm{Bcl}-2$ positivity next to a small fraction of M30 positivity. Poorly differentiated tumors instead showed the highest $\%$ of M30 positivity ( $>25 \%$ ). There was a significant difference in the $\%$ of M30 positivity between the hyperplasia and cancer samples (two sided $\mathrm{P}<0.0025$, Mann-Whitney-Test).

Conclusion: Transition of endometrial epithelium from hyperplasia to cancer, seems to involve both increased apoptosis and decreased bcl-2 expression. Flow cytometric evaluation of M30 and bcl-2 expression levels, with the SPF, in currettage specimens from postmenopausal patients complaining of bleeding, provides a quantitative assessment of endometrial apoptosis, bcl-2 expression and proliferation. Further studies are needed to determine the relationship between these three processes as indicators of the biological behaviour of gynecological tumors.

\title{
Introduction
}

In normal tissues, cell proliferation and cell death are balanced. However, neoplasms are the net result of an imbalance between cell proliferation and death. Until recently, studies have largely concentrated on cell proliferation and its association with the biological progression of neoplasia. However, apoptosis has been shown to play an essential role in tissue homeostasis ${ }^{4}$. Consequently, abnormalities in apoptosis regulation may contribute to the pathogenesis of neoplasms. Our objective was to evaluate the relation between differentiation, apoptotic and proliferative activities in endometrial adenocarcinomas, in comparison to a spectrum of benign endometrial entities. For this purpose we have used the following parameters.

$\mathrm{Bcl}-2$, a proto-oncogene encoding a $25-26 \mathrm{kd}$ protein, is located on the mitochondrial membrane, endoplasmic reticulum and nuclear membrane. The survival advantage provided by $\mathrm{Bcl}-2$ prolongs the life span of epithelial cells with differentiation potential and allows proliferation, differentiation and morphogenesis to proceed. Expression of its gene, located on $18 \mathrm{q} 21$, has been found to inhibit apoptosis $9.17,24$.

Cytokeratin 18 (CK18) has a widespread distribution in epithelia. Recently, CK filaments have been reported to aggregate rapidly in apoptotic cells ${ }^{3,11}$. Early during apoptosis of 
epithelial cells (before membrane assymetry and DNA strand breaks), a caspase cleavage event results in the unmasking of an epitope on cytokeratin 18 (CK18). This epitope is recognised by the monoclonal antibody $\mathrm{M} 30 . \mathrm{M} 30$ does not react with vital epithelial cells nor with necrotic cells. Its advantage is that it can be used for the quantification of apoptotic epithelial cells in routinely processed paraffin embedded tissues with simple immunohistochemical techniques ${ }^{16}$.

The SPF (S phase fraction) represents the fraction of cells in the phase of DNA synthesis, before duplication of the cell and thus reflects the proliferative capacity. Immunohistochemistry does not allow the demonstration or specific quantification of the SPF, whereas flow cytometry can.

In all situations where a disturbance of the balance between different processes is studied, an objective quantification of the contribution of each factor is important. Flow cytometry, and especially multiparameter flow cytometry, using cytokeratin antibodies to define the epithelial subpopulation as described by Leers et $\mathrm{al}^{14}$, can be of help to obtain such objective, qualitative and quantitative data. For this reason we have utilised this technique to evaluate the contribution of the various parameters mentioned above.

\section{Materials and methods}

\section{* SPECIMEN COLLECTION}

Formalin fixed, paraffin embedded tissues representing 54 patients were used for this study. Samples represented either fractional currettages or hysterectomies, fixed in $4 \%$ buffered formalin and then routinely processed for paraffin embedding. The classification of the endometrial phases was according to the criteria of Noyes et al ${ }^{18}$. For endometrial hyperplasia, the classification of the International Society of Gynecological Pathologists and the World Health Organization was used ${ }^{13}$. Staging of endometrial adenocarcinoma was based on the revised FIGO criteria, adopted from the UICC TNM Classification of Malignant Tumors ${ }^{5}$. Immunohistochemical stainings and gradings for Bcl-2, M30 and cytokeratin (CK) had been performed earlier on tissue sections from the corresponding blocks, independent of the flow cytometric analysis. The cases selected represented a spectrum of endometrial histological entities, summarized in Tables 1 and 2.

\section{* PREPaRATION OF CELl SUSPENSIONS}

For the preparation of the single cell suspension, the technique recently described by Leers et al was used ${ }^{15}$. Briefly, two fifty $\mu \mathrm{m}$ thick sections were cut from each paraffin block. Subsequently, these tissue sections were deparaffinized twice in xylene, 30 minutes each, and then rehydrated in a descending ethanol series. Sections were then rinsed in phosphate buffered saline (PBS; pH 7.2-7.4). The sections were then placed in a glass tube with cold citrate solution ( $2 \mathrm{mg}$ citric acid $/ \mathrm{ml}$ aqua dest; $\mathrm{pH}=6.0$ ), and then subjected to a 120 minute heating step in an $80^{\circ} \mathrm{C}$ water bath. After a short cooling down period, a 10 minute mild pepsin digestion step followed, at $37^{\circ} \mathrm{C}$ in a solution containing $1 \mathrm{mg} / \mathrm{ml}$ pepsin (Sigma, St. Louis, MO, USA) in $0.1 \mathrm{~N} \mathrm{HCl}$. A single cell suspension was obtained by vortexing and filtration of the sample through a $50 \mu \mathrm{m}$ mesh nylon filter. The cell suspension was then centrifuged at $400 \mathrm{~g}$ and the cell pellet was resuspended in PBS, supplemented with $1 \%$ bovine serum albumin (BSA/PBS buffer; Sigma). 


\section{* Multiparameter flow Cytometry}

The single cell suspension was aliquoted into $100 \mu 1$ samples. To each sample both properly diluted monoclonal and polyclonal antibodies were added simultaneously; mouse monoclonal antibody against Bcl-2 (clone 124, IgG1, DAKO A/S, Glostrup, Denmark, diluted 1:20) ${ }^{24}$ and M30 (clone M30, IgG2, Beki Diagnostics, Bromma, Sweden, diluted 1:100) ${ }^{16}$ and a polyclonal cytokeratin (DAKO A/S, Glostrup, Denmark, diluted 1:1000) ${ }^{15}$ to select the epithelial fraction. An overnight incubation at room temperature was followed by a double PBS rinsing step. The reaction of the primary antibodies was visualized by incubating the cell pellet simultaneously with the secondary antibodies, i.e. goat-anti-mouse-Ig-FITC (DAKO A/S, Glostrup, Denmark diluted 1:10) for the monoclonal antibody, and goat-anti-rabbit-IgRPE for the polyclonal antibody (Roche, Boehringer Mannheim, Germany, diluted 1:12) for $11 / 2$ hours at room temperature. The samples were rinsed in PBS two times and finally DNA was stained using propidium iodide (PI, $1.0 \mu \mathrm{g} / \mathrm{ml}$, Sigma) in PBS containing $0.1 \mathrm{mg} / \mathrm{ml}$ RNAse (Serva, Heidelberg, Germany). The samples were allowed to stand for minimal 1 hour in the dark at $4^{\circ} \mathrm{C}$ before flow cytometric analysis. As a negative control for background staining by the primary antibody, a portion of the cell suspension was incubated with a mouse monoclonal anti-Pneumocystis Carinii (Clone 3F6, DAKO A/S).

Table 1 Clinical and flow cytometric determined parameters of the benign samples included in this study.

\begin{tabular}{|c|c|c|c|c|c|c|c|}
\hline Tumor & \begin{tabular}{|c|} 
Age \\
|years] \\
\end{tabular} & Diagnosis & $\begin{array}{l}\text { Bcl-2+ve } \\
\text { Cells }[\%]\end{array}$ & $\mathrm{BCl}^{2} \mathrm{IR}^{1}$ & $\begin{array}{c}\text { M30+ve cells } \\
{[\%]}\end{array}$ & $\begin{array}{l}\text { SPF } \\
{[\%]}\end{array}$ & ploidy \\
\hline 1 & 45 & proliferative & 21.14 & 113 & 1.17 & 17.14 & Diploid \\
\hline 2 & 41 & proliferative & 18.97 & 89 & 4.9 & 17.82 & Diploid \\
\hline 3 & 38 & proliferative & 12.57 & 40.98 & 3.39 & 8.77 & Diploid \\
\hline 4 & 41 & proliferative & 10.18 & 37.67 & 2.98 & 11.7 & Diploid \\
\hline 5 & 37 & proliferative & 7.70 & 16.17 & 5.67 & 21.52 & Diploid \\
\hline 6 & 43 & secretory & 1.67 & 8 & 11.67 & 11.7 & Diploid \\
\hline 7 & 38 & secretory & 2.44 & 10.2 & 16.93 & 9.12 & Diploid \\
\hline 8 & 45 & secretory & 6.84 & 19.77 & 16.70 & 2.59 & Diploid \\
\hline 9 & 36 & secretory & 1.10 & 3.12 & 21 & 2.09 & Diploid \\
\hline 10 & 43 & secretory & 1.49 & 4.74 & 10.66 & 3.84 & Diploid \\
\hline 11 & 59 & postmenopausal & 10.81 & 66 & 10.4 & 9.55 & Tetraploid \\
\hline 12 & 72 & postmenopausal & 3.6 & 13 & 3.29 & 5.87 & Diploid \\
\hline 13 & 74 & postmenopausal & 16.66 & 58.81 & 3.89 & 7.06 & Diploid \\
\hline 14 & 69 & postmenopausal & 4.37 & 14.03 & 3.6 & 6.57 & Diploid \\
\hline 15 & 66 & postmenopausal & 2.15 & 9.29 & 6.07 & 11.71 & Diploid \\
\hline 16 & 82 & postmenopausal & 7.33 & 17.15 & 6.81 & 8.06 & Diploid \\
\hline 17 & 47 & simple hyperplasia & 3.92 & 19 & 10.88 & 17.49 & Tetraploid \\
\hline 18 & 63 & simple hyperplasia & 14.11 & 96 & 2.29 & 5.83 & Diploid \\
\hline 19 & 67 & simple hyperplasia & 14.38 & 43 & 4.13 & 5.96 & Diploid \\
\hline 20 & 41 & simple hyperplasia & 3.77 & 10 & 14 & 8.51 & Diploid \\
\hline 21 & 57 & simple hyperplasia & 5.56 & 20 & 4.97 & 5.66 & Diploid \\
\hline 22 & 46 & simple hyperplasia & 9.34 & 19.15 & 8.59 & 20.24 & Diploid \\
\hline 23 & 55 & simple hyperplasia & 8.16 & 34.76 & 8.58 & 11.35 & Diploid \\
\hline 24 & 35 & simple hyperplasia & 6.44 & 349 & 4.51 & 15.19 & Tetraploid \\
\hline 25 & 51 & complex & 3.97 & 4 & 9.57 & 10.16 & Aneuploid \\
\hline 27 & 69 & complex & 5.61 & 46 & 12.6 & 4.5 & Diploid \\
\hline 28 & 60 & complex & 21.8 & 64 & 16.45 & 10.35 & Diploid \\
\hline 29 & 76 & complex & 19.33 & 59 & 6.87 & 11.62 & Diploid \\
\hline
\end{tabular}

Bcl-2 immunoreactivity $=$ mean fluorescence intensity $\times \%$ of Bcl-2 positive cells 
Samples were analyzed using a FACScan flow cytometer (Becton Dickinson, San Jose, CA, USA). Cells were excited with a single $488 \mathrm{~nm}$ argon laser. FITC-fluorescence was detected through a $515-545 \mathrm{~nm}$ BP filter, RPE-fluorescence through a $572-588 \mathrm{~nm}$ BP filter and PIfluorescence through a $600 \mathrm{~nm}$ LP filter. Electronic gating was used to exclude doublets and cellular debris. At least 5000 relevant events were collected for each sample. FITC- and RPEsignals were recorded as logarithmic amplified data, while the PI-signals were recorded as linear amplified data. The following settings were used: $403 \mathrm{~V}, 338 \mathrm{~V}$ and $412 \mathrm{~V}$ on photomultiplier tubes for FL1 (FITC), FL2 (RPE) and FL3 (PI), respectively. Compensation for (FL1-\%FL2), (FL2-\%FL1), (FL2-\%FL3) and (FL3-\%FL2) was $0.9 \%, 18.6 \%, 13.5 \%$ and $8.3 \%$, respectively. Data analysis was performed using Lysys II software (Becton Dickinson).

Table 2: Clinical and flow cytometric determined parameters of the endometrial cancer samples evaluated in this study.

\begin{tabular}{|c|c|c|c|c|c|c|c|c|c|}
\hline Tumor & $\begin{array}{c}\text { Age } \\
\text { [years] }\end{array}$ & Grade & FIGO & Histological & $\begin{array}{c}\text { Bcl-2 +ve } \\
\text { cells }\end{array}$ & Bcl-2 IR & $\begin{array}{c}\mathrm{m} 30+\mathrm{VE} \\
\text { cells }\end{array}$ & $\begin{array}{l}\text { SPF } \\
{[\%]}\end{array}$ & ploidy \\
\hline 30 & 66 & 1 & IB & Papillary & 10,20 & 61 & 32,30 & 21,56 & Peridiploid \\
\hline 31 & 69 & 1 & IB & Endometrioid & 5,61 & 46 & 12,60 & 4,50 & Diploid \\
\hline 32 & 73 & 1 & IB & Endometrioid & 8,54 & 20 & 22,93 & 9,31 & Peridiploid \\
\hline 33 & 48 & 1 & IB & Endometrioid & 9,91 & 22 & 13,71 & 12,33 & Diploid \\
\hline 34 & 49 & 1 & IB & Endometrioid & 12,16 & 33 & 15,94 & 6,92 & Diploid \\
\hline 35 & 67 & 1 & IB & Endometrioid & 6,08 & 10 & 10,60 & 9,22 & Peridiploid \\
\hline 36 & 48 & 1 & IB & Papillary & 8,30 & 27 & 16,92 & 6,58 & Diploid \\
\hline 37 & 79 & 1 & IA & Endometrioid & 4,99 & 16 & 6,15 & 5,27 & Diploid \\
\hline 38 & 65 & 2 & IB & Papillary & 4,80 & 16 & 32,10 & 18,23 & Diploid \\
\hline 39 & 70 & 2 & IC & Endometrioid & 4,60 & 29 & 24,79 & 12,67 & Peridiploid \\
\hline 40 & 54 & 2 & IC & Endometrioid & 10,54 & 30 & 21,40 & 13,38 & Diploid \\
\hline 41 & 62 & 2 & IB & Endometrioid & 8,68 & 30 & 29,55 & 16,98 & Peridiploid \\
\hline 42 & 75 & 2 & IIIB & Endometrioid & 12,80 & 61 & 27,53 & 15,21 & Aneuploid \\
\hline 43 & 63 & 2 & IB & Endometrioid & 9,42 & 23 & 19,05 & 15,97 & Diploid \\
\hline 44 & 58 & 2 & IB & Endometrioid & 9,85 & 42 & 23,87 & 8,11 & Diploid \\
\hline 45 & 68 & 2 & IIA & Endometrioid & 8,88 & 23 & 21,69 & 12,21 & Aneuploid \\
\hline 46 & 61 & 2 & IB & Endometrioid & 5,53 & 12 & 21,05 & 3,16 & Diploid \\
\hline 47 & 60 & 2 & IC & Endometrioid & 7,29 & 11 & 27,36 & 12,26 & Diploid \\
\hline 48 & 68 & 2 & IB & Endometrioid & 6,28 & 12,31 & 4,90 & 9,96 & Diploid \\
\hline 49 & 71 & 3 & IIB & Endometrioid & 2,76 & 3 & 27,79 & $54.97 \dagger$ & Aneuploid \\
\hline 50 & 67 & 3 & IB & Papillary Serous & 3,31 & 10 & 24,38 & 12,14 & Diploid \\
\hline 51 & 76 & 3 & IIIC & Endometrioid & 3,50 & 9 & 28,04 & 16,67 & Diploid \\
\hline 52 & 61 & 3 & IB & Endometrioid & 3,59 & 8 & 24,08 & 15,44 & Diploid \\
\hline 53 & 80 & 3 & IB & Endometrioid & 1,44 & 3 & 26,22 & 24 & Aneuploid \\
\hline 54 & 76 & 3 & IIIA & Endometrioid & 3,73 & 7 & 29,49 & 15,07 & Aneuploid \\
\hline 55 & 84 & 3 & IIIB & Endometrioid & 3,80 & 31 & 15,41 & 11,76 & \\
\hline
\end{tabular}

$\mathrm{Bcl}-2$ immunoreactivity $=$ mean fluorescence intensity $\times \%$ of $\mathrm{Bcl}-2$ positive cells; $\uparrow=$ this value will be excluded out of the analysis because this is an unreliable high SPF (probably due to a technical error).

Cell cycle analysis was performed using Modfit LT 2.0 (Verity Software House Inc, Maine, USA). The following data were collected:

1) Ploidy and S-phase fraction (SPF) of the epithelial compartment

2) Coefficient of variation (CV) of the first $\mathrm{G}_{0} / \mathrm{G}_{1}$-peak

3) The percentage of $\mathrm{M} 30$ - or Bcl-2 positive cells in the epithelial compartment

4) The mean fluorescence intensity (MFI) of the bcl-2 positive epithelial cells.

The immunoreactivity of Bcl-2 was calculated by multiplying the mean fluorescence intensity by the $\%$ of $\mathrm{Bcl}-2$ positive cells. 
The number of positive cells was determined in the cytokeratin positive fraction of the cell suspension by an arbitrary threshold setting allowing not more than $5 \%$ positive counts in the negative control.

\section{* STATISTICS}

Median values with interquartile range (IQR) were used for the description of continuous data and small sample sizes. Where appropriate, mean values were given with standard deviation (SD). Correlations were calculated using the Spearman correlation coefficient $\left(\mathrm{r}_{\mathrm{s}}\right)$. The twosided Mann-Whitney-U-test and Kruskal-Wallis-test were used for group comparisons of unpaired continuous data where normality could not be assumed due to small case numbers. $\mathrm{P}$-values equal or smaller than 0.05 were considered significant. All presented $\mathrm{P}$ values were corrected for multiple comparisons using the Bonferroni correction method ${ }^{21}$.Correction for multiple comparisons was done using Bonferoni's method. All calculations were carried out using SPSS for Windows, version 8 (SPSS Inc., Chicago, U.S.A.).

\section{Results}

Of 54 samples examined, 26 represented endometrioid adenocarcinoma and 28 various cyclic and hyperplastic situations of the endometrium. This latter group was further divided into a group of 'normal, benign' tissues (including proliferative, secretory and postmenopausal endometrium; $\mathrm{n}=16$ ) and a group of benign disordered tissues (including simple and complex hyperplasia, $\mathrm{n}=12$ ). Clinical and flow cytometric data of these 54 patients are shown in Tables 1 and 2 . The mean age of patients with endometrioid adenocarcinoma was 66 years (standard deviation, SD 9.81), whilst 53 years (SD 13.91) for those with benign endometrium.
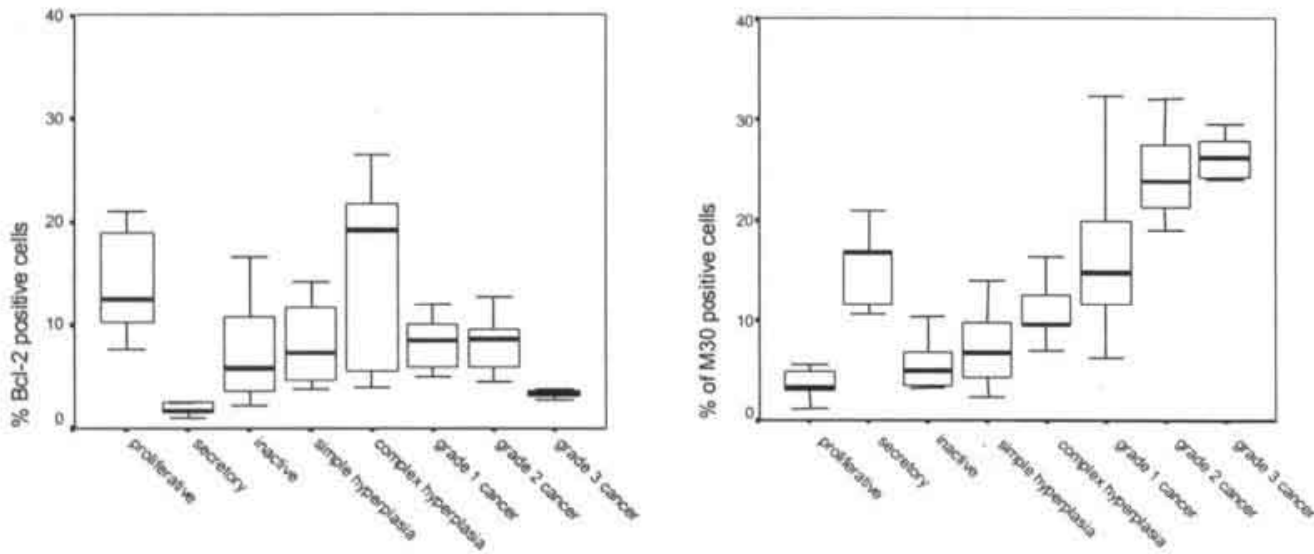

Figure 1+2 Anti-apoptotic (Bcl-2) and M30 patterns in all the endometrial groups studied.

In the normal, benign group of tissues an opposite expression pattern for bcl-2 and M30 was seen between proliferative and secretory endometrium. In proliferative endometrium a large fraction of bcl-2 positive cells (mean 14.1, SD 5.74) accompanied with a small number of M30 positive cells (mean 3.62 , SD 1.57) was seen. In the secretory phase of the endometrial 
cycle this was changed in a low number of bcl-2 positivity (mean 2.71, SD 2.36) and a large fraction of $\mathrm{M} 30$ positive cells (mean 15.39, SD 4.23).

The mean \% of $\mathrm{Bcl}-2$ positive cells in the malignant samples was $6.95 \%$ (SD 3.06) and the mean Bcl-2 immunoreactivity was 23.69 (SD 15.78), compared to $9.38 \%$ (SD 7.03) and 34.57 (SD 29.26) respectively for the benign disordered tissue samples. On the other hand, the mean $\%$ of M30 positive cells was $21.28 \%$ (SD 7.61) for the malignant samples, compared to $8.34 \%$, SD 5.11 , for the benign disorderd samples. A highly significant difference was found between the malignant and benign groups in terms of the apoptotic fractions ( $\%$ of M30 positive cells, two-sided $\mathrm{P}<0.0025$, Mann-Whitney-Test, two sided).

The highest mean \% of Bcl-2 positive cells in all the histological groups examined, was seen in complex hyperplasia. The secretory endometrium showed the highest mean $\%$ of M30 positive cells in all the benign groups examined (Figures $1+2$ ).

The hyperplasia group showed an increase in mean \% of Bcl-2 and M30 positive cells and SPF from simple to complex hyperplasia. Grade 1 cancer showed a median $\%$ of $\mathrm{Bcl}-2$ positive cells $(8.42 \%$, IQR $4.40 \%)$ nearly half that of complex hyperplasia $(19.33 \%$, IQR $19.42 \%$ ), however no significant difference between them could be shown. Grade 1 cancer showed a median \% of M30 positive cells ( $14.83 \%$, IQR $10.33 \%$ ) whilst complex hyperplasia showed $9.57 \%$ (IQR $6.40 \%$ ). There was a highly significant difference in the apoptotic fractions (\% of M30 positive cells) between the hyperplasia and endometrioid adenocarcinoma samples all together (two sided $\mathrm{P}<0.0025$, Mann-Whitney-Test, two sided). The mean $\%$ of $\mathrm{Bcl}-2$ positive cells as well as the mean Bcl-2 immunoreactivity (not shown in figure) dropped from grade 1 to grade 3 cancer as seen in Figure 1. This was also supported by the finding of a significant intermediate negative correlation between the $\%$ of $\mathrm{Bcl}-2$ positive cells and histological grade $\left(r_{s}=0.603\right.$, Spearman's two-sided correlation, $\left.\mathrm{P}<0.004\right)$. There was a significant difference in the $\%$ of Bcl-2 positive cells (two sided $\mathrm{P}<0.005$ and $\mathrm{P}<$ 0.0025 respectively, Mann-Whitney test) between grade 1 (median $8.42 \%$, IQR $4.40 \%$ ) and grade 3 , and grades 2 (median $8.68 \%$, IQR $4.32 \%$ ) and grade 3 cancer (median $3.54 \%$, IQR

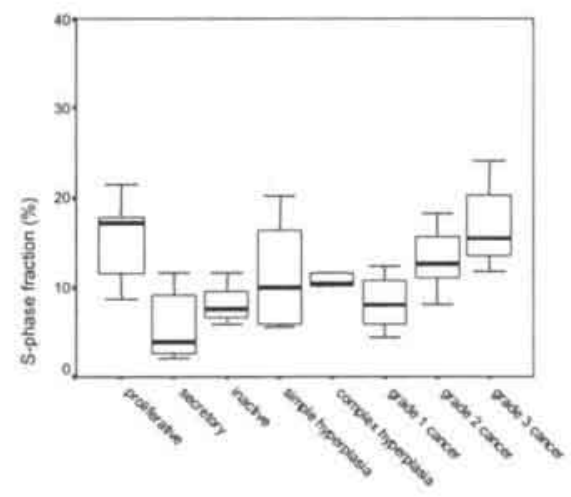

Figure 3 SPF in all the endometrial groups studied.

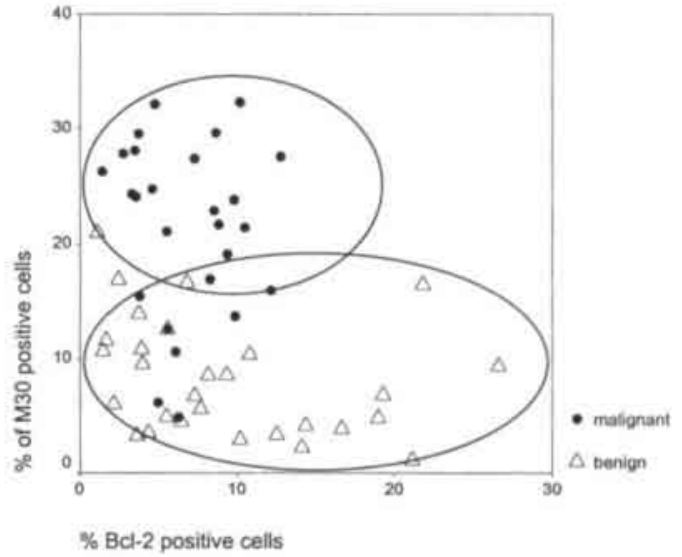

Figure 4: Distribution of $\mathrm{Bcl}-2$ and $\mathrm{M} 30$ reactivity in the benign versus the malignant samples. Areas 1 and 2 are arbitrary ellipsoids defining $90 \%$ of the benign and $90 \%$ of the malignant samples respectively. 
$0.90 \%$ ). On the other hand, the median $\%$ of M30 positive cells increased with increasing endometrial cancer grades (Figure 2). This observation was supported by a small, positive correlation between the $\%$ of M30 positive cells and histological grade $\left(r_{\mathrm{s}}=0.430\right.$, Spearman's two-sided correlation, $\mathrm{P}=0.13$ ). One case of grade 1 (number 30 , Table 2 ) and one case of grade 2 cancer (number 38 , Table 2 ) showed relatively high apoptotic fractions ( $\%$ of M30 positive cells, $>30 \%$ ). Both cases belonged to the papillary variant of endometrioid adenocarcinoma.

The median SPF increased from grade 1 to grade 3 cancer (Figure 3), this was supported by a non significant intermediate positive correlation between histological grade and SPF $\left(r_{\mathrm{s}}=\right.$ 0.465 , Spearman's two-sided correlation, $\mathrm{P}=0.076)$. The median S-phase fractions increased from grade 1 (median $8.07 \%$, IQR 5.98) through grade 2 (median $12.67 \%$, IQR $6.01 \%$ ) to grade 3 (median $15.25 \%$, IQR $6.46 \%$ ). One case of a grade 3 tumor (case no.49) had an unreliable high SPF, probably due to a technical error (the Ki67 staining on a tissue section of this tumor showed no exceptional high expression of this proliferation marker). Because of this, this case was excluded from the statistical analysis. In the malignant samples a strong significant correlation was found between apoptotic (M30) fractions and SPF as seen in Figure 5 (Spearman's two-sided correlation, $\mathrm{p}<0.004, \mathrm{r}_{\mathrm{s}}=0.738$ ).

Regarding FIGO staging, the median \% of Bcl-2 positive cells was $6.78 \%$ (IQR $4.90 \%$ ) for stage I, $5.82 \%$ for stage II and $3.76 \%$ (IQR $6.99 \%$ ) for stage III. In contrast with histological grading, the median Bcl-2 immunoreactivity was highest in stage III disease (20, IQR 46.0). The highest median Bcl-2 MFI was also seen in stage III disease (3.74, IQR 5.24). The median $\%$ of M30 positive cells was highest in FIGO stage III disease $(27.79 \%$, IQR $10.69 \%)$. The highest median SPF was seen in stage II disease (33.59\%). No correlation was found between FIGO stages or histological type and Bcl-2, M30 positive fractions or SPF.

Regarding the DNA index (ratio of mean peak channel value of sample $G_{0} / G_{1}$ population divided by mean peak channel value of diploid reference cells) ${ }^{15}$ and ploidy status, 40 samples from the total number examined were diploid (index of 1 ). The remaining 15 samples showed peridiploidy (DNA index $=1-1.10, \mathrm{n}=5$ ), tetraploidy (DNA index $=2, \mathrm{n}=4$ ) and 'real' aneuploidy (DNA index neither $0.5,1-1.10$ nor $2, \mathrm{n}=5$ ). The samples showing peridiploidy represented 3 patients with grade 1 cancer and 2 patients with grade 2 cancer. Those showing tetraploidy represented 2 patients with simple hyperplasia, 1 patient with complex hyperplasia and 1 patient with postmenopausal endometrium. Those showing aneuploidy represented 1 case with complex hyperplasia, 2 cases with grade 2 cancer and 2 cases with grade 3 cancer. DNA indices revealed that $40-42 \%$ of grade 1 and 2 cancers and $50 \%$ of grade 3 cancers were aneuploid. The highest bcl-2 activity (median \% of Bcl-2 positive cells; $8.62 \%$, IQR $18.12 \%$, as well as median Bcl-2 immunoreactivity: $33.45 \%$, IQR $35.98 \%$ ) was seen in the samples showing tetraploidy. However, the tumor samples showing aneuploidy showed the highest apoptotic activity (median \% of M30 positive cells; $26.22 \%$, IQR $12.9 \%$ ). The highest proliferative activity was also seen in the samples showing aneuploidy with a median SPF of $16.34 \%$ (IQR 8.77).

The same patient with postmenopausal endometrium and a tetraploid DNA profile, developed later on well differentiated endometrioid adenocarcinoma, FIGO stage Ia, for which she underwent a hysterectomy. (However, an incomplete fractional currettage specimen, not representative of the whole uterine cavity, at the time of initial presentation could not be excluded). 


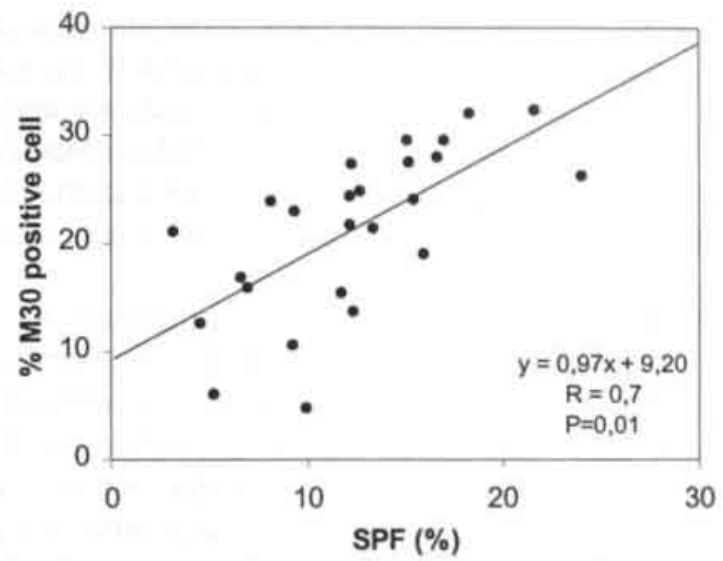

Fig. 5 The correlation (Spearman's correlation, two-sided) between the apoptotic and proliferative fractions in the endometrial adenocarcinoma samples ( $\mathrm{SPF}=\mathrm{S}$ phase fraction).

\section{Discussion}

Many methods exist to detect apoptosis including light microscopy ${ }^{1}$, electron microscopy, flow cytometry, agarose gel DNA electrophoresis, in situ nick-end labelling (ISEL), TdTmediated dUTP nick end labelling (TUNEL), and the detection of phosphatidylserine (PS) on the outer plasma membrane using Annexin V. Leers et al. showed that structures recognized by the M 30 monoclonal antibody increase in exponentially growing epithelial cell lines after induction of apoptosis. In a flow cytometric assay, M30-positive cells appeared in the apoptotic subG $_{1}$-peak. Tests with synthetic peptides defined positions 387-396 of CK18, with a liberated $\mathrm{C}$-terminus at the caspase cleavage site $\mathrm{DALD}^{\star} \mathrm{S}$, as the 10-residue epitope of $\mathrm{M} 30^{16}$.

Studies of inhibition of apoptosis (Bcl-2), apoptosis and proliferation in endometrial tumors have primarily been conducted by immunohistochemical techniques. These methods, while important in investigating the biological characteristics of these tumors, are subjective for clinical application. In contrast, flow cytometric analysis allows a rapid quantification and objective assessment of these parameters for clinical purposes. In addition, when performing multiparameter flow cytometry these parameters can be directly correlated with proliferative activity (SPF) and DNA ploidy in the relevant epithelial (cytokeratin positive) compartment of endometrial tumors. To our knowledge, this is the first study that involves multiparameter flow cytometric evaluation of cell death and proliferation together, in routinely processed paraffin embedded endometrial adenocarcinoma.

This study objectively documents the presence of apoptosis, anti-apoptosis and proliferation in the endometrium, whether in the normal cycle, the postmenopausal state, the hyperplastic state and last but not least, endometrial adenocarcinoma. This would be expected given the continuous state of cell death and renewal that occurs in the female reproductive tract. The mean apoptotic fraction of the endometrial adenocarcinoma group, was approximately three times as much as that in the benign groups all together. Simultaneously, evidence of antiapoptosis decreased from the benign to the endometrial adenocarcinoma group. Other studies reported similar findings where morphological evidence of increased apoptosis was found in 
high-grade endometrial adenocarcinomas and was more pronounced in tumor areas with a solid growth pattern. This correlated inversely to Bcl-2 expression levels which was seen more in normal endometrium but reduced in atypical hyperplasia and carcinomas ${ }^{7,20,22}$. Based on these studies together with the quantitative data obtained by multiparameter flow cytometry, it seems to us that increased apoptosis together with decreased bcl-2 expression could play a role in the transition from normal endometrium to endometrioid adenocarcinoma passing through the state of hyperplasia.

The equilibrium between cell proliferation and cell death is important for tissue homeostasis. In normal tissues these two processes are balanced, such that a homogenous cell population is directed towards either proliferation or apoptosis depending on additional signals ${ }^{2}$. This was evidenced by the high proliferative fractions together with prominent bcl-2 activity seen in the first half of the cycle, with hardly any detectable apoptotic activity. In the second half however, apoptotic activity increased together with decreased bcl-2 expression and proliferation. These findings are in concordance with immunohistochemical studies published by Gompel et $\mathrm{al}^{6}$, Spencer et $\mathrm{al}^{23}$, Otsuki et $\mathrm{al}^{19}$ and Koh et $\mathrm{al}^{10}$. Concerning the postmenopausal endometrium, the inhibition of apoptosis as detected by Bcl-2 reactivity was dominant together with hardly any detectable apoptotic or proliferative activity. This is to be expected given the relatively static nature of this endometrial state.

Contrary to the inverse relationship between apoptosis and proliferation found in proliferative, secretory and postmenopausal endometrium, the hyperplasia group showed a concomitant increase in mean bcl-2, apoptotic and proliferative fractions from simple to complex hyperplasia. Furthermore, the latter group is considered to be premalignant ${ }^{12}$.

On the other hand, in grade 1 endometrial adenocarcinoma, the median apoptotic fraction was high compared to complex hyperplasia whilst the median bcl-2 positive fraction dropped to nearly half that of complex hyperplasia. Therefore it appears that changes of endometrial histology are associated with specific changes in the expression patterns of these proteins. Evaluation of bcl-2, apoptotic and proliferative profiles of inactive endometrium, together with DNA information, by multiparameter flow cytometer could assist in the diagnostic workup of postmenopausal patients with endometrial hyperplasia and allow the detection of high risk patients for endometrial adenocarcinoma.

In the endometrial adenocarcinoma group, bcl-2 expression decreased while apoptotic activity and proliferative fractions increased with increased tumor grading. That is to say that highly differentiated tumors showed lower apoptotic fractions and higher anti-apoptotic fractions than their counterparts. This finding can be explained by being a manifestation of severely dysregulated control over apoptosis and/or proliferation accompanying malignant progression (for example incorrect working cell cycle checkpoints). Apoptosis has been found to be generally increased in cancer. Diverse factors have been implicated in an attempt to explain this phenomenon, including frequent foci of apoptosis in regions of tumor ischemia, tumor necrosis factor $\alpha$ release by invading macrophages, FAS-mediated apoptosis by cytotoxic Tlymphocytes, co-influence on apoptosis by cancer genes that have been activated in the process of neoplastic development, increased sensitivity to apoptosis as a result of loss of matrix attachement or cell-cell contacts or merely a result of processes intrinsic to the tumor cells, with differing rates of apoptosis being found in otherwise similar tumors expressing different oncogenes ${ }^{8,22}$.

Generally in the endometrial adenocarcinoma samples examined, high apoptotic fractions were always accompanied by high proliferative fractions. Our results revealed a significant 
association between proliferative and apoptotic fractions in the tumors evaluated. A similar finding has been shown by Saegusa et al between the apoptotic index and the mitotic count in endometrial carcinoma ${ }^{20}$. Steck and his co-workers have also shown similar relationships between increased proliferation and programmed cell death in breast carcinomas. These results indicate that tumors with high proliferative rates are associated with an increase in apoptosis. In the review of apoptosis by Kerr et $\mathrm{al}^{8}$, the explanation proposed for this phenomenon was that the putative cell population regulatory mechanisms come into play at an early stage of the process of carcinogenesis, with increased apoptosis acting as a temporary regulatory mechanism, aborting any increased proliferation that may occur.

In conclusion, multiparameter DNA flow cytometry provides a valuable tool for rapid, quantitative evaluation of processes related to the cell cycle. Concurrent evaluation of cell proliferation, anti-apoptotic (Bcl-2) and apoptotic (by the monoclonal M30 antibody) activities may provide detailed analysis of different parameters that may reflect the intrinsic biological characteristics of specific cell populations in a tumor. Furthermore, the apoptotic fraction (M30 positive fraction) can serve as an additional tool, in conjunction with morphological criteria, to better stratify endometrial cancer grades and histological variants of endometrioid adenocarcinoma, such as the papillary variant that showed high levels of apoptosis. This can reflect the intrinsic behaviour of the tumor as well as predict its possible response to antitumor therapy. In addition, information about the cell cycle position, of the respective population studied, can be compared before and after cancer therapy. This can be utilised to tailor more effective therapies through the expanding understanding of apoptosis and its role in cancer.

Multiparameter DNA flow cytometric evaluation of M30 and Bcl-2 levels of expression in fractional currettage specimens from patients complaining of postmenopausal bleeding, provides a quantitative means of assessing endometrial apoptosis and anti-apoptosis, in order to identify patients at risk for endometrial cancer as well as differentiate hyperplastic from non-hyperplastic endometrial conditions. This could allow for better stratification of patients for different treatment protocols. Further studies are required to determine the relationship between these parameters and the patients' clinical outcome.

\section{Acknowledgements}

We would like to thank Frau Dr. Margarete Mitze for providing the pathological specimens. 


\section{References}

1. Bedner E, Li X, Gorczyca W, Melamed MR, Darzynkiewicz Z. Analysis of Apoptosis by Laser Scanning Cytometry. Cytometry 1999; 35: 181-195.

2. Carson DA, Ribiero JM. Apoptosis and disease. Lancet 1993; 341: 1251-1254.

3. Caulin C, Salvesen GS, Oshima RG. Caspase Cleavage of Keratin 18 and Reorganization of Intermediate Filaments during Epithelial Cell Apoptosis. J Cell Biol 1997; 138: 1379-1394.

4. Engeland M,van, Nieland LJW, Ramaekers FCS, Schutte B, Reutelingsperger CPM. Annexin V-Affinity Assay: A Review on an Apoptosis Detection System Based on Phosphatidylserine Exposure. Cytometry 1998; 31: 1-9.

5. FIGO criteria and the TNM staging of carcinoma of the uterine body. UICC TNM Classification of Malignant Tumors, LH Sobin, Ch. Wittekind (eds), fifth edition. 1997.

6. Gompel A, Sabourin JC, Martin A, Yaneva H, Audoin J, Decroix Y, Poitout P. Bcl-2 expression in normal endometrium during the menstrual cycle. Am J Pathol 1994; 144: 1195-1202.

7. Heatley MK. Association between the apoptotic index and established prognostic parameters in endometrial adenocarcinoma. Histopathology 1995; 27: 469-472.

8. Kerr JFR, Winterford CM, Harmon BV. Apoptosis. Its Significance in Cancer and Cancer Therapy. Cancer 1994; 73: 2013-2026.

9. Kluck RM, Bossy-Wetzel E, Green DR, Newmeyer DD. The Release of Cytochrome c from Mitochondria: A Primary Site for Bcl-2 Regulation of Apoptosis. Science 1997; 275: 1132-1136.

10. Koh EA, Illingworth PJ, Duncan WC, Critchley HO. Immunolocalization of bcl-2 protein in human endometrium in the menstrual cycle and simulated early pregnancy. Hum Reprod 1995; 10: 1557-1562.

11. Ku N-O, Liao J, Omary MB. Apoptosis Generates Stable Fragments of Human Type I Keratins. J Biol Chem 1997; 272: 33197-33203.

12. Kurman RJ, Norris HJ. Endometrial Neoplasia: Hyperplasia and Carcinoma. In: Blaustein A, editors. Pathology of the Female Genital Tract. 2nd ed. New York: Springer Verlag, 1982: pp 311 - 351.

13. Kurman RJ, Norris HJ. Endometrial Hyperplasia and Related Cellular Changes. In: Kurman RJ editor. Blaustein's Pathology of the Female Genital Tract. 4th ed. New York: Springer-Verlag, 1994: pp 411- 438.

14. Leers MPG, Theunissen PHMH, Ramaekers FCS, Schutte B. Multi-Parameter Flow Cytometric Analysis With Detection of the Ki67-Ag in Paraffin Embedded Mammary Carcinomas. Cytometry 1997; 27: 283 - 289.

15. Leers MPG, Schutte B, Theunissen PHMH, Ramaekers FCS, Nap M. Heat Pretreatment Increases Resolution in DNA Flow Cytometry of Paraffin-Embedded Tumor Tissue. Cytometry 1999; 35: 260-266.

16. Leers MPG, Kölgen W, Björklund V, Bergman T, Tribbick G, Persson B, Björklund P, Ramaekers FCS, Björklund B, Nap M, Jörnvall H, Schutte B. Immunocytochemical detection and localization of a cytokeratin 18 epitope exposed during early apoptosis. J Pathol 1999; 187: 567-572.

17. Lu Q-L, Abel P, Foster CS, Lalani E-N. bcl-2: Role in Epithelial Differentiation and Oncogenesis. Hum Pathol 1996; 27: $102-110$.

18. Noyes RW and Hertig AT, Dating the Endometrial Biopsy. Fertil Steril 1955; 1:3-25.

19. Otsuki Y, Misaki O, Sugimoto O, lto Y, Tsujimoto Y, Akao Y. Cyclic bcl-2 gene expression in human uterine endometrium during menstrual cycle. Lancet $1994 ; 344: 28-29$.

20. Saegusa M, Kamata Y, Isono M, Okayasu I. Bcl-2 expression is correlated with a low apoptotic index and associated with progesterone receptor immunoreactivity in endometrial carcinomas. J Pathol 1996; 180: 275-282.

21. Shankey TV, Rabinovitch PS, Bagwell B, Bauer KD, Duque RE, Hedley DW, Mayall BH, Wheeles L, Cox C. DNA Cytometry Consensus Conference. Cytometry 1993; 14:472-477.

22. Soini Y, Päăkkő P, Lehto V-P. Histopathological Evaluation of Apoptosis in Cancer. Am J Pathol 1998; 153: 1041 1053.

23. Spencer SJ, Cataldo NA, Jafe RB. Apoptosis in the human female reproductive tract. Obstet Gyn Survey 1996; 51: 314-323.

24. Steck KD, McDonnell TJ, El-Naggar AK. Flow Cytometric Analysis of Apoptosis and Bcl-2 in Human Solid Neoplasms. Cytometry 1995; 20: 154-161. 
Summary, general discussion and conclusions 


\section{General discussion}

In this thesis the feasibility of multiparameter flow cytometric analyses in routinely processed formalin fixed, paraffin embedded tissues has been examined. Next to this, several clinical applications of this approach have been investigated.

\section{Feasibility and modifications to the technique}

In chapter $\mathbf{2}$ it was shown that it is possible to perform multiparameter DNA flow cytometry on formalin fixed, paraffin embedded tissues. After preparing a single-cell suspension the cells had retained enough cytoskeletal remnants to allow immunocytochemical detection of the cytokeratins. Labeling of the cytokeratins can be used to restrict the flow cytometric analysis to the epithelial compartment of a tumor after selection of the cytokeratin-positive cells. As shown in chapter 2 , but also by several other investigators ${ }^{6,8,9}$, exclusion of nonepithelial cells (inflammatory cells and stromal compartment) from the flow cytometric analysis increases the accuracy of the SPF calculation and could enhance the prognostic value of DNA flow cytometry. In diploid tumors this multiparameter flow cytometric analysis allows a more objective SPF calculation due to this exclusion of normal non-epithelial cells. Also, the quality of the DNA histogram improved as indicated by a decrease in CV.

There are several enzymes which can be used to prepare the single cell suspension. Pepsin has a broad range of nonspecific proteolytic activities. After pepsin digestion, this Ki67-epitope was not detectable anymore with the Ki67-antibodies tested. On the other hand, trypsin is a more specific enzyme: a serine protease that hydrolyses peptide bonds involving carboxyl groups of arginine and lysine. This specificity of trypsin can be used to detect a Ki67-epitope using a particular Ki67-antibody (KiS5) in cell suspensions prepared from formalin fixed, paraffin embedded breast tumors (chapter 3 ).

A drawback of enzymatic digestion is that due to the long digestion period (more than one hour) many epitopes are destroyed, especially the membrane bound antigens. When the $50 \mu \mathrm{m}$ thick deparaffinized and rehydrated sections were heated for 2 hours at $80^{\circ} \mathrm{C}$ in a citrate solution, a very short pepsin digestion of maximally 15 minutes was sufficient to release more than enough cells from the section to perform a multiparameter flow cytometric analysis (chapter 4). Due to the very short enzymatic digestion, many epitopes survive the adverse effects of an enzymatic treatment. Next to this, the heating step in citrate solution has also an antigen retrieving effect. Now it is possible to detect epitopes which could not be analysed before in paraffin embedded tissues, for example the steroid receptors (chapter 7),but even cell membrane bound epitopes such as E-Cadherin (unpublished observations) and CDmarkers on lymphoid cells (chapter 8).

Another advantage of this technique is that the adverse effects of formalin fixation on the nuclear dye uptake are counteracted. This leads to an improvement of the quality of the DNA histogram (low CV, small fraction of background and debris). Formalin fixation leads to the formation of methylene bridges between amino-acids in the DNA and/or proteins. Heating in an acidic environment (the citrate solution has a pH of 6.0) leads to an extraction of chromatin proteins which results in more binding sites for propidium. It was also shown in chapter 4 
that the duration of fixation with formalin up to 72 hours has no influence on propidium iodide uptake. When using external reference cells this new method can facilitate the standardisation of flow cytometry on formalin fixed, paraffin embedded tissues. The presented method allows for the setup of standardization and quality controls.

Using an indirect immunostaining method, it is possible to perform a three-parameter flow cytometric analysis of formalin fixed, paraffin embedded tissues (chapter 3, 5, 6, 7, 8 and 9). Next to a DNA-staining with propidium iodide, it is possible to label simultaneously two epitopes using a combination of a mono- and a polyclonal antibody. However, it is even possible to use a combination of two monoclonal antibodies when using immunoglobulinisotype different monoclonal antibodies (e.g. an $\mathrm{IgG}_{1^{-}}$and an $\mathrm{IgG}_{2 \mathrm{a}}$ or $\mathrm{IgG}_{2 \mathrm{~b}}$-monoclonal antibody; chapter 6).

\section{Clinical applications}

A significant limitation of using a single marker to predict disease course (i.e. DNA ploidy or $\mathrm{SPF}$ ) is that it fails in a number of individual patients. One reason is the presence of tumor heterogeneity. Other reasons include technical issues, which limit the reproducibility of the assay. A consensus panel suggested that multiparameter techniques would improve the accuracy and prognostic utility of flow cytometric data ${ }^{7,11}$. Much of the clinical applications of flow cytometry have thus far centered around the use of cell surface phenotyping in the analysis of fresh material of leukemias and lymphomas. Although DNA ploidy and S-phase analysis have been performed in clinical laboratories for over twenty years, they have limited impact on clinical management of solid tumors at the present time. An important factor that has contributed to this was the lack of reproducibility of many studies, especially those performed on formalin fixed, paraffin embedded tissues. It was shown in this thesis that this problem can be solved by the new heating/short digestion method to prepare single cell suspensions from the paraffin embedded tissues (chapter 4). Due to this new method a higher DNA histogram resolution was achieved resulting in a better recognition of peridiploid tumor cell populations. Using multiparameter flow cytometry direct correlations could be made between the expression of a tumor marker in a certain cell population on the one hand, and ploidy level and SPF on the other hand. In chapter 7 it was shown in patients with a breast tumor that this analysis leads to the identification of four subsets of patients:

1. patients with DNA aneuploid tumors, high SPF and low ER-expression

2. patients with DNA aneuploid tumors, including the peri- and tetraploid ones, intermediate SPF and relatively high ER-expression

3. patients with DNA diploid tumors, low SPF, high ER- and high PR-expression, and finally 4. patients with DNA diploid tumors, low SPF, high ER- and low PR-expression

From several studies it is known that patients suffering from tumors with a diploid DNA profile, low SPF and high ER-expression respond better to hormonal treatment. On the other hand, it was also shown that patients with aneuploid tumors or tumors with a high SPF have a significantly increased rate of tumor relapse ${ }^{3}$. An advantage of the method described in chapter 7 is that these different parameters (steroid hormone receptor expression, DNA ploidy and SPF) are obtained within one single assay and are all related to the same investigated cell population. Next to the steroid hormone receptors, cell membrane bound epitopes could be analysed. In the same group of breast tumors investigated in chapter 7 , the 
expression of the cell membrane bound epitope E-cadherin was investigated (unpublished observations). It was shown that this expression was correlated to the $\mathrm{N}$-stage of the tumor, i.e. tumors, which had not metastasized, had a high E-cadherin expression. Most of these tumors were also diploid. Tumors which had metastasized showed next to aneuploidy no or decreased expression of E-cadherin.

Barnard et al have found in breast tumors that the expression of the proliferation-associated antigen Ki67 provides an objective indicator of biological behaviour and may thus be of clinical significance. In chapter 3, a rapid, objective multiparameter flow cytometric method is described to analyse the expression of the Ki67-epitope in cell suspensions from formalin fixed, paraffin embedded breast tumors.

The expression of the above-described proteins (steroid hormone receptors, E-cadherin and Ki67) was always investigated in the relevant epithelial compartment of the tumor: the cytokeratin-positive cell population. For this purpose, a polyclonal pan-cytokeratin antibody was used to label these cells. However the different lineages of epithelial differentiation and their tumors are characterised by the expression of a certain subset of cytokeratins. In chapter 6 it was shown that a differentiation could be made between normal bronchial epithelium and tumor epithelium in one single flow cytometric analysis of lung carcinomas when using monoclonal antibodies directed to certain cytokeratin subtypes. Now it is possible to study the expression of a certain protein during differentiation of that cell.

From several studies it is known that cytokeratin filaments aggregate at an early stage of the apoptotic process ${ }^{5,14}$. This aggregation is accompanied by caspase cleavage of the cytokeratin filaments ${ }^{2}$. In chapter 5 we characterised antibody M 30 , which can be used in a routine setting for the analysis of the apoptotic process by multiparameter flow cytometry. Early in the apoptotic cascade, caspase-cleavage of cytokeratin 18 takes place. A neo-epitope is then generated which is recognized by the monoclonal antibody M30. In this chapter it is excluded that this epitope is present in vital and necrotic cells. It was also shown that this epitope is not generated by hyperphosphorylation (artificial or natural during mitosis) of cytokeratin 18 . Because cytokeratin 18 has a widespread distribution in practically all simple, non-stratified, ductal and pseudostratified epithelia, it can be used for studies of many types of carcinomas. Furthermore, recent studies in cell lines have shown that the caspase cleaved CK18 fragments, which are detectable by M30, are finally shed into the culture medium (Kölgen et al, manuscript in preparation). Measuring serum levels of these fragments could provide a simple assay to monitor progression of disease or response to therapy.

In chapter 9 proliferation (SPF) and apoptosis (bcl-2, M30) was studied in benign and malignant disorders of the endometrium. Multiparameter flow cytometric evaluation of these three parameters could help to assist in the identification of patients at risk for endometrial cancer: patients with a low number of M30 positive cells combined with a high number of bcl2 positive cells in hyperplastic endometrium. With this method it was also possible to make a differential diagnosis between hyperplastic from non-hyperplastic endometrial lessions.

In chapter 8 it was shown that next to cytokeratin also cell surface epitopes can be used to characterize certain subpopulations of cells. The cell surface markers CD79a and CD3 were used to label the B- and T-lymphocyte population within paraffin embedded lymphatic tissue. Furthermore, the expression of immunoglobulin light chains was investigated within the CD79a-positive population. Using this method it was possible to detect clonal expression of one of the two immunoglobulin light chains in 9 out ot 10 non-Hodgkin's lymphomas. In this way a differentiation could be made between the expression of the light chain 
immunoglobulins in the normal diploid lymphocytes (both $\kappa$ - and $\lambda$-light chain expression) and that of the peridiploid tumor cells (no light chain expression). With routine immunohistochemical techniques it was only possible to detect clonal expression in 6 out of ten cases.

\section{Future research}

To test the clinical value and the prognostic significance of the above mentioned applications, it is of importance to repeat these studies in a series of tumors with a long follow up of a well documented cohort of patients to get a definitive answer. Because the flow cytometric technique now works excellent on routinely processed formalin fixed, paraffin embedded material, such series can now be selected. Now that it is shown that the technique of multiparameter flow cytometry works on formalin fixed, paraffin embedded tumors it is of importance to look for the right combinations of markers, that provide information about the biological behavior of the tumor. An example is the analysis of the expression of apoptosisinhibiting proteins. At the moment, several trials have been initiated in which apoptotic pathways are manipulated. In prostate cancer for example, it has been shown that downregulation of bcl-2 expression with gene-specific antisense oligonucleotide probes abolish the bcl-2 conferred resistance to apoptosis induction ${ }^{1,13}$. These observations suggest that bcl-2 can be a prime target for interference in preventing the generation of androgenrefractory prostatic cancer cells. Blocking bcl-2 expression with unmodified or phosphorothiate antisense oligonucleotides may also provide beneficial effects for combined hormonal ablation and cytotoxic chemotherapy ${ }^{4,10}$.

In a pilot study we found that when calculating the ratio between apoptosis (as determined by M30 expression) and proliferation (as determined by the SPF) a highly significant difference exists between metastasised (N1) and not metastasised breast tumors (N0). The N0-tumors contained a higher ratio in contrast to the N1-tumors (manuscript in preparation). Sheridan et al found a similar result when calculating this ratio using morphological criteria (combination of mitosis-counting and TUNEL-assay) ${ }^{12}$. They found that cervical adenocarcinomas with a high ratio had an improved survival after radiotherapy. This ratio, which we defined as the Tumor Dynamic Index (TDI), is easily analyzed in a single-tube assay. In a pilot study on the effect of photodynamic treatment of breast tumor explants in mice, a response was accompanied with an increased TDI within several hours after treatment (personal communication H. Walt). Multiparameter flow cytometry of fine needle aspirates of the residual tumor, or malignant effusions, might be well suited to monitor cancer patients during and after therapy.

Data analysis in multiparameter FCM is one of the limiting factors. Complex data files containing more than three-parameters can require over 20 plots to visualize data trends across all dimensions. It becomes difficult to find subpopulations with a certain marker profile when the analysis is restricted to the two-dimensional plots generated by the most used analysis programs. In order to visualize multiparameter flow cytometric data it is desirable to reduce the dimensionality of these data to two while preserving important features of each data pattern. Programs, which make use of attractors, have been developed recently. These are cluster-seeking objects that automatically track user-defined cell populations. These attractors are not static gates or quadrants, but are made up of dynamic gates. On subsequent analyses of 
samples, this software program automatically adjusts to relative changes in populations, without the intervention of the operator. Next to this, the productivity, the quality and the reproducibility of the flow cytometric analyses will improve when data analysis can be automated.

However, the objectivity of the result of such quantification depends on the subjective determination of thresholds and cut-off values when interpreting the flow cytometric generated data by the investigator. This problem can be solved by adding reference cells to the single cell suspensions. There is a variety of reference cells which can be used: cells with a certain DNA content, with a certain diameter, labeled with a certain amount of fluorescent probe etc. Using the method described in this thesis, the heating/ short digestion method, in combination with those reference cells could lead to standardization of flow cytometry on formalin fixed, paraffin embedded tissue. It also improves the possibility of exchanging materials and results between diagnostic laboratories.

\section{Conclusion}

From the results of the various studies described in this thesis it can be concluded that multiparameter flow cytometry of formalin fixed, paraffin embedded tissue is to become an important tool for the surgical pathologist. It has many potential clinical applications and can already now aid in the diagnosis of certain pathological disorders. It can give a more objective quantification of the expression of several proteins as compared to the immunohistochemical approaches or single-parameter flow cytometric analysis. 


\section{References}

1. Berchem GJ, Bosseler M, Sugars LY, Voeller HJ, Zeitlin S, Gelman EP. Androgens induce resistance to bcl-2 mediated apoptosis in LNCaP prostate cancer cells. Cancer Res 1995; 55; 735-738

2. Caulin, C., Salvesen, G. S. \& Oshima, R. G. Caspase cleavage of keratin 18 and reorganization of intermediate filaments during epithelial cell apoptosis. J Cell Biol 1997; 22: 379-394

3. Clark GM, McGuire WL. Steroid receptors and other prognostic factors in primary breast cancer. Semin Oncol 1988; 15: 20-25

4. Dawson NA, Wilding G, Weiss RB, McLeod DG, Linehan WM, Frank JA, Jacob JL, Gelmann EP. A pilot study of chemohormonal therapy for metastatic prostate cancer. Cancer 1992; 69: 213-218

5. Engeland M, van, Kuijpers HJH, Ramaekers FCS, Reutelingsperger CPM, Schutte B. Plasma membrane alterations and cytoskeletal changes in apoptosis. Exp Cell Res 1997; 235: 421-430

6. Glogovac JK, Porter PL, Banker DE, Rabinovitch PS. Cytokeratin labeling of breast cancer cells extracted from paraffin embedded tissue for bivariate flow cytometric analysis. Cytometry 1996; $24: 260-267$

7. Hedley DW, Clark GM, Cornelisse CJ, Kilander D, Kute T, Merkel D. Consensus review of the clinical utility of DNA cytometry in carcinoma of the breast. Cytometry 1993; 14: 482-485

8. McCormick SR, Avis AA, Schrauth JB. Flow cytometric DNA analysis with cytokeratin gating of formalin fixed deparaffinized breast cancer nuclei. Am J Clin Pathol 1998; 110: 227-237

9. Nylander K, Stenling R, Gustafsson H, Roos G. Application of dual parameter analysis in flow cytometric DNA measurements of paraffin embedded samples. J Oral Pathol Med 1994; 23: 190-192

10. Reed JC, Stein C, Subasinghe C, Haldar S, Croce C, Yum S, Cohen C. Antisense-mediated inhibition of bcl-2 protooncogene expression and leukemic cell growth and survival: Comparison of phosphodiester and phosphorothioate oligodeoxynucleotides. Cancer Res 1990; 50: 6565-6570

11. Shankey TV, Rabinovitch PS, Bagwell B, Bauer KD, Duque RE, Hedley DW, Mayall BH, Wheeles L, Guidelines for implementation of clinical DNA cytometry. Cytometry 1993; 14: 472-477

12. Sheridan MT, Cooper RA, West CM. A high ratio of apoptosis to proliferation correlates with improved survival after radiotherapy for cervial adenocarcinomas. Int J Radiat Oncol Biol Phys 1999; 44: 507-512

13. Tang DG, Porter A. Target to apoptosis: a hopeful weapon for prostate cancer. Prostate 1997; 32: 284-293

14. Tinnemans, M. M., Lenders, M. H., Velde, G. P. ten, Ramaekers, F. C. S. \& Schutte, B. Alterations in cytoskeletal and nuclear matrix-associated proteins during apoptosis. Eur J Cell Biol 1995; 68: $35-46$ 


\section{Samenvatting}

In dit proefschrift worden de mogelijkheden van de multiparameter flow cytometrie in routinematig verwerkt weefsel materiaal beschreven en worden klinische toepassingen daarvan geîllusteerd.

\section{* TECHNISCHEMODIFCATIES}

$\mathrm{Na}$ een algemene inleiding (hoofdstuk 1) wordt in hoofdstuk 2 aangetoond dat het mogelijk is om multiparameter flow cytometrie te verrichten op formaline gefixeerd en in paraffine ingebed materiaal. $\mathrm{Na}$ de bereiding van een celsuspensie door middel van een enzymatische (pepsine) digestie-stap, blijkt dat de cellen genoeg cytoskelet-resten bezitten om daarin door middel van immunochemische technieken epitopen aan te tonen, waaronder de cytokeratines. Door het labelen van de cytokeratines kan door selectie de flow cytometrische analyse beperkt worden tot het epitheliale compartiment van de tumor.

In hoofdstuk 3 wordt aangetoond dat door gebruik te maken van een modificatie in de celsuspensie-bereidingsmethode (gebruik van trypsine in plaats van pepsine), het gevoelige epitoop Ki67 (een proliferatie-geassocieerd eiwit) flow cytometrisch aangetoond kan worden. $\mathrm{Na}$ een pepsine-digestie is het epitoop niet meer aantoonbaar. Wel moet benadrukt worden dat alleen het Ki-S5 monoclonaal in staat is dit epitoop te labelen in celsuspensies van formaline gefixeerd, paraffine ingebed weefsels. Een algemeen nadeel van de enzymatische digestiemethode is dat zeer gevoelige epitopen, zoals die van celmembraan geassocieerde eiwitten, als eerste vernietigd worden en dus niet meer aantoonbaar zijn middels immunochemie. In hoofdstuk 4 van dit proefschrift onderzochten we daarom een methode waarbij gedeparaffineerde en gerehydreerde dikke coupes $(50 \mu \mathrm{m}) 2$ uur verhit worden in een citraatoplossing ( $\mathrm{pH} \mathrm{6.0)} \mathrm{bij} 80^{\circ} \mathrm{C}$. Na een korte afkoelingsperiode blijkt een zeer korte enzymatische digestie (5-10 minuten bij $30^{\circ} \mathrm{C}$ ) voldoende om genoeg cellen te isoleren voor multiparameter flow cytometrisch onderzoek. Een van de voordelen van deze methode is dat door de korte digestie-stap veel epitopen behouden blijven waaronder de celmembraan geassocieerde epitopen. Verder heeft de verhitting in de citraatoplossing een "ántigen retrieval"-effect. Het is nu mogelijk om epitopen te herkennen die voorheen niet aantoonbaar waren in celsuspensies bereid van formaline gefixeerde weefsels zoals bijvoorbeeld de steroid hormoonreceptoren (hoofdstuk 7), E-cadherine (niet gepubliceerde data) en CD-markers op lymfoide cellen (hoofdstuk 8). Een ander voordeel van deze techniek is dat het nadelige effect van formaline fixatie op de binding van propidium iodide aan het DNA wordt opgeheven. Dit leidt tot een verbetering van de kwaliteit van het DNA-histogram (lage CV, geringe fractie debris). Ook blijkt de duur van de fixatie (tot 72 uur) geen rol meer te spelen op de bepaling van de ploidie. Door referentiecellen mee te nemen kan deze nieuwe methode leiden tot standaardisatie van flow cytometrie op formaline gefixeerde en in paraffine ingebedde weefselmateriaal. Deze resultaten bieden nieuwe perspectieven voor de uitwisseling van kwaliteitscontrole-materiaal binnen en tussen laboratoria. 


\section{* KLINISCHE TOEPASSINGEN}

Door het gebruik van multiparameter flow cytometrie is het mogelijk om de expressie van bepaalde tumormarkers in specifieke celpopulaties direct te correleren aan ploidie-graad en Sfase fractie. In hoofdstuk 3 wordt een (semi)kwantitatieve multiparameter flow cytometrische techniek voor de expressie van het Ki67-epitoop in het epitheliale compartiment van formaline gefixeerde, paraffine ingebedde mammatumoren beschreven. Uit de literatuur is bekend dat de expressie van dit proliferatie-geassocieerd epitoop gerelateerd is aan het klinisch gedrag van mammatumoren en dus van klinische betekenis kan zijn.

De expressie van de steroidhormoonreceptoren en Ki67 werd in deze gehele studie steeds onderzocht in het relevante epitheliale compartiment van de tumor: de cytokeratine positieve celpopulatie. Voor dit doel werden de cellen gelabeld met een antilichaam gericht tegen een algemeen voorkomend epitoop op het cytokeratine-filament (pan-cytokeratine antilichaam). Echter, de verschillende vormen van epitheeldifferentiatie en de hieruit ontstane tumoren worden gekenmerkt door een expressiepatroon van bepaalde cytokeratines. In hoofdstuk 6 wordt aangetoond dat door gebruik van antilichamen gericht tegen specifieke subtypes van cytokeratines flow cytometrisch onderscheid kan worden gemaakt tussen normaal bronchiaal epitheel en tumor epitheel in longtumoren. Het is dus mogelijk om op basis van deze expressiepatronen longtumoren beter te typeren.

Vanuit verschillende studies is bekend dat de cytokeratine filamenten in een vroeg stadium van het apoptose proces gaan aggregeren. Deze aggregatie word vergezeld door een klieving van het cytokeratine filament door caspase. In hoofdstuk 5 wordt een antilichaam gekarakteriseerd dat gericht is tegen een neo-epitoop op cytokeratine 18. Dit epitoop wordt gegenereerd door een caspase-klieving van het cytokeratine 18, vroeg in het apoptose-proces en wordt herkend door het M30-antilichaam. In dit hoofdstuk wordt aangetoond dat het epitoop niet aanwezig is in vitale of necrotische cellen en niet gegenereerd wordt door hyperfosforylatie van cytokeratine 18. Daar cytokeratine 18 wijdverbreid voorkomt in praktisch alle nietverhoornende epithelia, kan het antilichaam gebruikt worden in studies van veel typen epitheliale tumoren.

In hoofdstuk 7 wordt de expressie van steroidhormoonreceptoren gecorreleerd aan ploidiegraad en S-fase fractie in een groep patiënten met een mammacarcinoom. Door de expressie van de steroidhormoonreceptoren (ER en PR) in de epitheliale fractie van de tumor te correleren aan ploidie en S-fase fractie, kunnen een aantal subgroepen van patiënten onderscheiden worden. Uit de literatuur is bekend dat patiënten die een tumor hebben met een diploid DNA-profiel, lage proliferatieve activiteit en hoge steroid hormoonreceptor expressie beter reageren op hormonale therapie. Anderzijds is ook aangetoond dat patiënten met een aneuploide mammatumor, een lage expressie van steroidhormoonreceptoren of een tumor met een hoge S-fase fractie een significante toename vertonen van terugval in de ziekte.

In hoofdstuk 9 worden de proliferatieve, bcl-2 expressie (apoptose-remming) en apoptotische activiteit (M30) onderzocht in benigne en maligne afwijkingen van het endometrium. Multiparameter flow cytometrische evaluatie van deze drie parameters kan een steun zijn bij het vaststellen van een subgroep van patiënten met hogere risico's voor het ontwikkelen van een endometriumcarcinoom, namelijk een groep endometriumafwijkingen met een geringe fractie van M30-positieve cellen gecombineerd met een hoge bcl-2 expressie in hyperplastisch endometrium. Met deze methode is het ook mogelijk om een differentiaal diagnose te maken tussen hyperplastische en niet-hyperplastische endometriumafwijkingen. 
Naast de cytokeratines kunnen ook membraan-eiwitten gebruikt worden om bepaalde subpopulaties van cellen te karakteriseren. In hoofdstuk 8 wordt aangetoond dat celmembraangebonden epitopen bij uitstek geschikt zijn om de verschillende populaties in lymfatisch weefsel te labelen. Door gebruik te maken van antilichamen gericht tegen CD3 en CD79a kunnen respectievelijk de $\mathrm{T}$ - en B-lymfocytenpopulaties aangetoond en gekwantificeerd worden in celsuspensies bereid van paraffine ingebedde lymfoproliferatieve afwijkingen. Daarnaast wordt getoond dat binnen de CD79a-positieve populatie de expressie van de immunoglobuline lichte ketens onderzocht kan worden. Door gebruik te maken van deze methode was het mogelijk om klonale expressie van een van de twee types immunglobuline lichte ketens aan te tonen in 9 van 10 non-Hodgkin's lymfomen. Met de routinematig toegepaste immunohistochemische techniek was dit in 6 van de 10 gevallen mogelijk. Door gebruik te maken van de simultane DNA-aankleuring met propidium iodide kon ook nog onderscheid gemaakt worden tussen de expressie van de immunoglobuline lichte ketens in de diploide en aneuploide lymfocyten.

Aan de hand van de verschillende resultaten zoals beschreven in dit proefschrift kan gekonkludeerd worden dat de multiparameter flow cytometrische techniek toegepast op routinematig verwerkt formaline gefixeerd, paraffine ingebed materiaal een belangrijk hulpmiddel in de diagnostiek van de klinisch patholoog kan zijn. Op gebied van de kwantificering geeft de multiparameter flow cytometrie een objectiever resultaat in vergelijking tot immunohistochemische benaderingen. 


\section{List of publications}

\section{Full papers}

1. Theunissen PHMH, Leers MPG, Bollen ECM. Proliferating cell nuclear antigen (PCNA) expression in formalin fixed tissue of non-small cell lung carcinoma. Histopathology 1992; 20: 251-255.

2. Leers MPG. Celproliferatietechnieken in de histopathologie. Analyse 1993; 48: 130-133

3. Boon ES, Leers MPG, Tjwa MKT. Ectopic Cushing's syndrome in a patient with squamous cell carcinoma of the lung due to CRF-like production. Monaldi Arch Chest Dis 1994; 1: 19-21

4. Leers MPG, Theunissen PHMH, Schutte B, Ramaekers FCS. Bivariate cytokeratin/DNA flow cytometric analysis of paraffin embedded samples from colorectal carcinomas. Cytometry 1995; 21: 101-107

5. Leers MPG, Theunissen PHMH, Schutte B, Ramaekers FCS. Bivariaat cytokeratine/DNA flow cytometrie analyse van formaline gefixeerde, paraffine ingebedde solide tumoren. Histotechniek/Cytovisie 1996;4: 510

6. Leers MPG, Theunissen PHMH, Koudstaal Joh, Schutte B, Ramaekers FCS. Trivariate flow cytometric analysis of paraffin embedded lung cancer specimens: application of cytokeratin subtype specific antibodies to distinguish between differentiation pathways. Cytometry 1997; 27: 179-188

7. Leers MPG, Theunissen PHMH, Ramaekers FCS, Schutte B. Multiparameter flow cytometric analysis with detection of the Ki67-antigen in paraffin embedded mammary carcinomas. Cytometry 1997; 27: 283-289.

8. Leers MPG, Aarts MMJ, Theunissen PHMH. E-Cadherin and calretinin: a useful combination of immunochemical markers for differentiation between mesothelioma and metastatic adenocarcinoma. Histopathology 1998; 32: 209-216

9. Sulzer MA, Leers MPG, van Noord JA, Bollen ECM, Theunissen PHMH. Reduced E-Cadherin expression is associated with increased lymph node metastasis and unfavorable prognosis in non-small cell lung cancer. Am J Respir Crit Care Med 1998; 157: 1319-1323

10. Retera J, Leers MPG, Sulzer MA, Theunissen PHMH. The expression of $\beta$-catenin in non-small cell lung cancer: a clinicopathological study. J Clin Pathol 1998; 51: 891-894

11. Leers MPG, Schutte B, Theunissen PHMH, Ramaekers FCS, Nap M. Heat pretreatment increases resolution in DNA flow cytometry of paraffin embedded tumor tissue. Cytometry 1999; 35: 260-266

12. Leers MPG, Kölgen W, Björklund V, Bergman T, Tribbick G, Persson B, Bjorklund P, Ramaekerз FCS, Bjorklund B, Nap M, Jörnvall H, Schutte B. A novel apoptosis assay: M30. Immunocytochemical detection and localization of a cytokeratin 18 epitope exposed during early apoptosis. J Pathol 1999; 187:567-572

13. Leers MPG, Theunissen PHMH, Schutte B, Ramaekers FCS, Nap M. Multiparameter flow cytometric steroid receptor analysis in paraffin embedded breast carcinomas. Human Pathology 1999; in press

14. Kölgen W, Leers MPG, Björklund V, Bjorklund P, Bergman T, Tribbick G, Persson B, Bjorklund B, Nap M, Jörnvall H, Ramaekers FCS, Schutte B. Caspase cleavage of cytokeratin 18 is an early event in apoptosis detected by M30. Manuscript in preparation.

15. Morsi HM, Leers MPG, Jäger W, El Kabarity H, Nap M. The patterns of expression of an apoptosis related $\mathrm{CK}$ neoepitope, the $\mathrm{Ki} 67$ proliferation marker and the bcl-2 proto-oncogene in normal, hyperplastic and malignant endometrium. Int J Gyn Oncol 1999; accepted

16. Leers MPG, Theunissen PHMH, Ramaekers FCS, Schutte B, Nap M. Clonality assessment by multiparametric flow cytometry on formalin fixed, paraffin embedded tissue is a useful tool for the diagnosis of malignant B cell non-Hodgkin's lymphoma. Submitted

17. Morsi HM, Leers MPG, Jäger W, Radespiel-Troger M, El Kabarity H, Bjorklund V, Nap M, Lang N. Apoptosis,Bcl-2 expression and proliferation in endometrial adenocarcinoma; an approach using multiparameter flow cytometry. Submitted

18. Robert-Offerman SR, Leers MPG, Suylen v RJ, Nap M, Daemen MJAP, Theunissen PHMH. Evaluation of the membrane attack complex of complement for the detection of a recent myocardial infarction in man. $\mathrm{J}$ Pathol 1999; accepted. 


\section{Dankwoord}

Aan het eind gekomen van mijn proefschrift rest me nu alleen nog de taak om iedereen te bedanken die op enigerlei wijze hebben geholpen tot het tot stand komen van dit proefschrift. Aangezien ik ervan overtuigd ben dat ik door alle drukte een aantal personen vergeet op te noemen bied ik hiervoor alvast mijn excuses aan en begin met te zeggen: Bedankt allemaal.

Als eerste wil ik de beide pathologen, dr. M.Nap en dr. P.H.M.H. Theunissen, bedanken dat zij mij de ruimte en tijd hebben gegeven om dit onderzoek te doen. Beste Marius, jouw komst naar Heerlen betekende voor mij een extra stimulans daar jij net zoals ik geinteresseerd was in de wetenschap en flow cytometrie. Ik hoop dat je geen spijt hebt gehad van deze keuze en dat we in de toekomst nog vele ideeen bij het koffieapparaat in de gang mogen verzinnen. Beste Paul, hoewel een beetje op de achtergrond was je wel altijd geinteresseerd in de voortgang van het onderzoek en was je altijd bereid om een nieuw artikel steeds kritisch te corrigeren om zo de scherpe randjes er vanaf te halen. Ook zorgde je steeds voor de statistische bewerkingen en kon ik steeds hieromtrent een beroep op je doen.

Dan de heren in Maastricht, prof.dr. F.C.S. Ramaekers en dr. B. Schutte. Toen ik zo'n vijf jaar geleden een brief naar jullie stuurde met de vraag om de flow cytometrische techniek bij jullie te leren, wie kon toen vermoeden dat daar een promotie-onderzoek uit zou rollen. Jullie waren altijd zo gastvrij om bij jullie, op de afdeling Moleculaire Celbiologie, dié experimenten te doen die in onze instelling niet mogelijk waren. Beste Frans, hoewel ik het begin en eind niet meer zag als ik een gecorrigeerd manuscript van je terugkreeg wist je wel altijd de essentiele zaken in de manuscripten te benadrukken zodat de review van de meeste manuscripten door de editorial board van de verschillende tijdschriften vaak gesmeerd en snel verliep. Beste Bert, ik hoop dat we nog vaak over DNA flow cytometrie van gedachten kunnen wisselen. Jouw inbreng zorgde er steeds voor dat de verhalen compleet waren en dat er geen enkel storende factor vergeten was. Ik hoop dat na dit promotie-onderzoek de samenwerking met jullie onveranderd doorgaat.

Dan dr. Joh. Koudstaal. U was het die me destijds in liet zien dat ik meer iemand was voor het wetenschappelijk onderzoek. U zorgde voor de mogelijkheid om te studeren en creëerde tijd en ruimte om aan een eigen onderzoeksproject te beginnen.

De leden van de beoordelingscommissie, onder voorzitterschap van prof.dr. J.W. Arends wil ik bedanken voor hun kritische beoordeling van het manuscript.

Dan mijn directe collega's in Heerlen. Jan en Iris, bedankt voor het in de gaten houden wanneer er vers materiaal voor mij binnenkwam. Jan, trouwens nog bedankt voor de tip met glasparels, maar vertel me het in het vervolg enkele jaren eerder. Gerda, op jouw kon ik altijd terugvallen wanneer er een hele serie coupes voor dit project immunohistochemisch gekleurd moesten worden. Ook was je altijd bereid om werk uit mijn handen te nemen zodat ik meer tijd in dit onderzoek kon steken. Dit geld trouwens ook voor de rest van de mensen op het PAlab die ik niet allemaal bij naam zal noemen. Ik realiseer me terdege dat door dit project jullie vaak mijn gedeelte van routine-werkzaamheden hebben moeten opvangen. Bedankt!

Dan de dames van de flow cytometrie op de afdeling Hematologie onder leiding van Marion, jullie zorgden er steeds voor dat de flow cytometer start klaar stond zodat ik meteen kon gaan meten. Hoewel ik weleens af en toe vergat om de buffer- of waste-vat te vernieuwen konden jullie iedere dag de planning van werkzaamheden zo aanpassen zodat ik langs kon komen. Nu 
de afdeling Pathologie een eigen flow cytometer heeft, is dit kontakt iets minder geworden. Maar jullie zijn altijd welkom om eens ons apparaat uit te proberen.

Dear dr. H. Morsi, Hassan, your stay in our lab resulted in several manuscripts. One of these is included in this thesis. It was a nice coörporation and I hope that you understand now why 30 tubes is the maximum. Good luck and we keep in touch.

Verder wil ik de diverse nog niet bij naam genoemde co-auteurs van de afzonderlijke hoofdstukken bedanken voor de voor ieder op hun eigen vakgebied gewaardeerde inbreng. Dan mijn ouders. Zoals jullie zien is het me toch gelukt. Bedankt voor de belangstelling die jullie door de jaren heen toonden.

Tenslotte het thuisfront. Sanne en Veerle, hoewel ik altijd probeerde tijd voor jullie vrij te maken schoot het toch vaak erbij in. Ik beloof dat dit nu zal veranderen. Bianca, je bleef in me geloven. Hoewel je het onderwerp soms niet helemaal kon volgen, had je toch vaak een luisterend oor. Zonder al te veel mopperen heb je mijn avonden werk geaccepteerd. Ik hoop dat je in de toekomst niet vaak meer prei-schotel hoeft te maken. 


\section{Curriculum vitae}

De schrijver van dit proefschrift werd geboren op 13 juni 1966 te Sittard. Na het volgen van de MAVO ging hij in 1982 naar de Zuidlimburgse Laboratoriumschool (ZLS) te Sittard voor het volgen van de middelbare laboratoriumopleiding, richting cyto-/histologie. Hierna vervolgde hij de hogere laboratoriumopleiding, richting 'Microscopische technieken' aan de OLAN (Opleiding Laboratoriumpersoneel Arnhem Nijmegen) te Nijmegen. Voor zijn afstudeeropdracht liep hij in 1989/1990 stage op de vakgroep Pathologie (prof.dr. F. Bosman, dr. A. de Goeij) in het Biomedisch Centrum verbonden aan de Universiteit van Maastricht. $\mathrm{Na}$ het behalen van zijn diploma startte hij in 1990 als allround analist op de afdeling Pathologie van het 'De Wever Ziekenhuis. Na twee jaar werken pakte hij in 1992 in zijn vrije tijd het studeren weer op door het volgen van de 'Wetenschappelijke opleiding Toegepaste Natuurwetenschappen: Voeding \& Toxicologie' aan de Open Universiteit te Heerlen. In 1994 werd kontakt gelegd met de vakgroep Moleculaire Celbiologie \& Genetica (prof.dr. F.C.S. Ramaekers en dr. B. Schutte) voor begeleiding bij zijn doctoraalscriptie. In 1995 werd deze scriptie, getiteld 'Toepassingen van immunochemische merkstoffen in de flow cytometrie' afgerond (begeleiders Open Universiteit Heerlen: prof.dr. M.C.E. van Dam-Mieras, dr. M. Niesink). Hiermee werd ook de basis gelegd voor het onderwerp van dit proefschrift. In maart 1998 rondde hij zijn WO-opleiding aan de Open Universiteit af.

In zijn vrije tijd is de schrijver als hoofdagent werkzaam bij de Vrijwillige Politie, basiseenheid Sittard-West, district Limburg Zuid. Hij is getrouwd met Bianca Janssen en heeft twee dochters, Sanne (5) en Veerle (1). 

